\title{
Biodiesel Research Progress 1992-1997
}

K. Shaine Tyson, Editor

Prepared by

Information Resources, Inc. Contract \#: ACG-7-17046-01

Dyncorp Information \& Engineering Technology Contract \#: YAH-5-15099-01

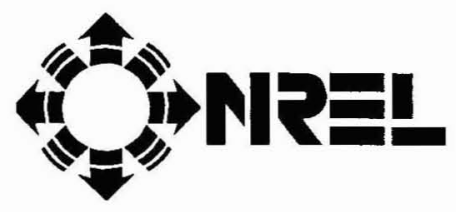

National Renewable Energy Laboratory 1617 Cole Boulevard

Golden, Colorado 80401-3393

A national laboratory of the U.S. Department of Energy Operated by Midwest Research Institute for the U.S. Department of Energy Under Contract No. DE-AC36-83CH10093 
This publication was reproduced from the best available camera-ready copy submitted by the subcontractor and received no editorial review at NREL.

\section{NOTICE}

This report was prepared as an account of work sponsored by an agency of the United States government. Neither the United States government nor any agency thereof, nor any of their employees, makes any warranty, express or implied, or assumes any legal liability or responsibility for the accuracy, completeness, or usefulness of any information, apparatus, product, or process disclosed, or represents that its use would not infringe privately owned rights. Reference herein to any specific commercial product, process, or service by trade name, trademark, manufacturer, or otherwise does not necessarily constitute or imply its endorsement, recommendation, or favoring by the United States govemment or any agency thereof. The views and opinions of authors expressed herein do not necessarily state or reflect those of the United States government or any agency thereof.

Available to DOE and DOE contractors from:

Office of Scientific and Technical Information (OSTI)

P.O. Box 62

Oak Ridge, TN 37831

Prices available by calling (423) $576-8401$

Available to the public from:

National Technical Information Service (NTIS)

U.S. Department of Commerce

5285 Port Royal Road

Springtield, VA 22161

(703) 487-4650 


\title{
Biodiesel Research Progress 1992-1997
}

\author{
K. Shaine Tyson, Editor
}

Prepared by

Information Resources, Inc.

Contract \#: ACG-7-17046-01

Dyncorp Information \& Engineering Technology Contract \#: YAH-5-15099-01

National Renewable Energy Laboratory 1617 Cole Boulevard

Golden, Colorado 80401-3393

A national laboratory of the U.S. Department of Energy Operated by Midwest Research Institute for the U.S. Department of Energy Under Contract No. DE-AC02-83CH10093

Prepared under Task No. BF886001 


\section{Table of Contents}

TABLE OF CONTENTS

ACKNOWLEDGMENTS

I. INTRODUCTION AND HOW TO USE THIS REPORT 10

A. Introduction 10

B. How to Use this Report

II. PRODUCTION 12

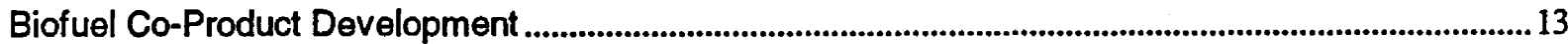

Hydrogenated Soy Ethyl Ester (HySEE), Preliminary Processing and Screening Work.......................... 14

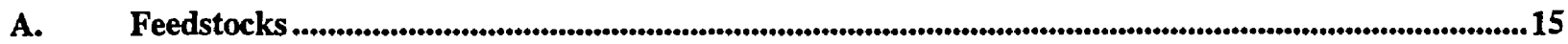

Assessment of Biomass Feedstocks Suitable for the Production of Liquid Biofuels.................................16

Biodiesel From Microalgae: Complementarity in a Fuel Development Strategy.......................................17

Close-Out of Microalgae Component of Biodiesel Program .........................................................................18

$\mathrm{CO}_{2}$ Mitigation in Fossil-Fueled Power Plants Using Microalgae with Co-production of Biodiesel.........19

Developing Yellow Mustard (Sinapis Alba L.) Cultivators Suitable for Biodiesel Production in the

United States

Multifeedstock Biodiesel Project (in earlier phase, the project was titled "Cost-Effective Options for

Testing of Biodiesel from Low-Cost Feedstocks) .........................................................................................22

Potential Feedstock Supply and Costs for Biodiesel Production ................................................................22

Prevailing Markets for Biodiesel Feedstocks_An Empirical Overview....................................................25

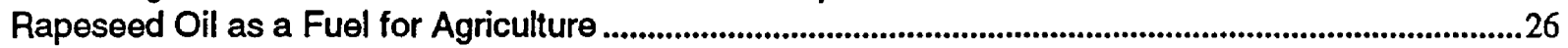

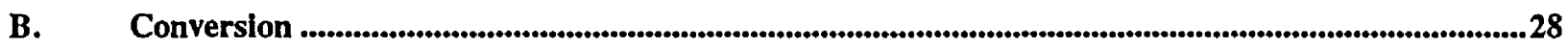

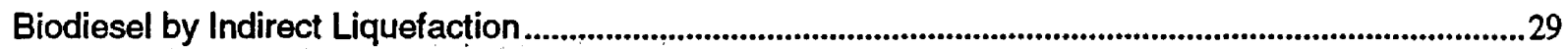

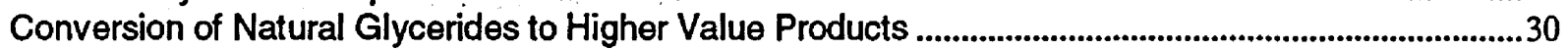

Ethyl Ester Process Scale-Up and Biodegradability of Biodiesel..................................................................33

Hydrogenated Soy Ethyl Ester (HySEE) Process Refinement.................................................................35

New Processes for Obtaining Higher Value-Added Products from Agricultural Lipids ............................36

Process Scale-Up for Catalytic Oxidation of Unsaturated Fatty Acids and Glycerolysis..........................37

Process Scale-up for Transesterification an Glycerolysis of Soybean Oil Utilizing a High Shear Liquid-

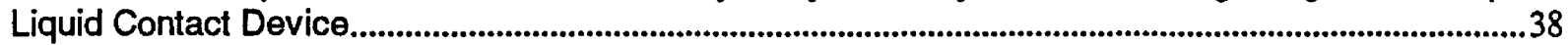

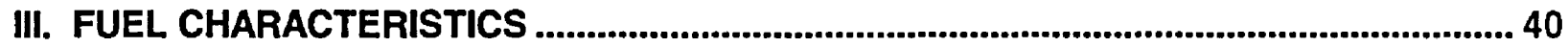

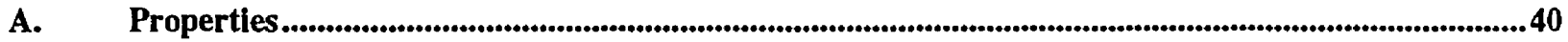

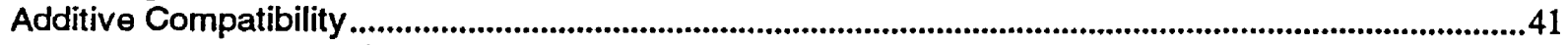

ASTM Standards Development and Industry Acceptance ....................................................................42

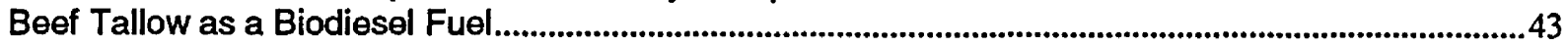

Biodiesel Cetane Number Engine Testing Comparison to Calculate Cetane Index Number..................44

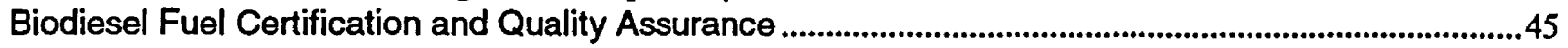

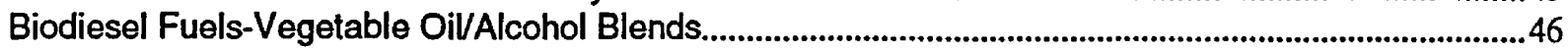

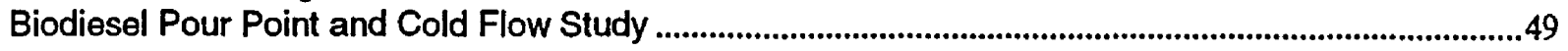


Biodiesel Technical Fuel Quality Laboratory Analysis......................................................................50

Blending Rules for Formulating Biodiesel Fuel .................................................................................51

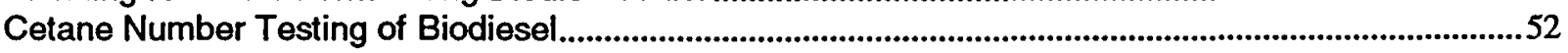

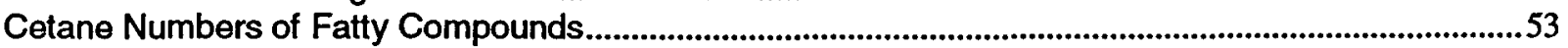

Development of Premium Diesel Fuel Standards.................................................................................54

Diesel Fuel, Extenders and Additives from Vegetable Oils...........................................................................55

Development of Biodiesel Slurry Fuels....................................................................................................57

Improving the Low-Temperature Properties of Alternative Diesel Fuels: Vegetable Oil-Derived Methyl

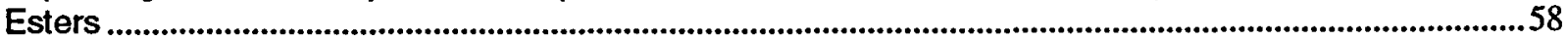

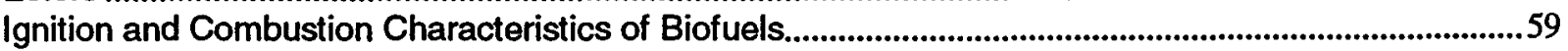

Low-Temperature Filterability Properties of Alternative Diesel Fuels from Vegetable Oils ...................60

Low-Temperature Properties of Triglyceride-Based Diesel Fuels: Transesterified Methyl Esters and

Petroleum Middle Distillate/Ester Blends.

National Alternative Fuels Laboratory-Phase V .........................................................................................62

National SoyDiesel Development Board Standards for Biodiesel ............................................................64

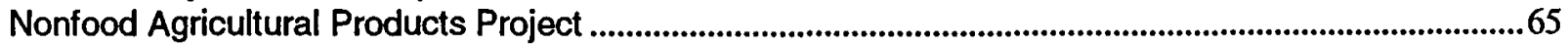

Oxidative and Thermal Stability Testing Method(s) for Biodiesel...............................................................67

Properties of Alternative Fuels............................................................................................................................68

Rapeseed and Safflower Oils as Diesel Fuels.....................................................................................69

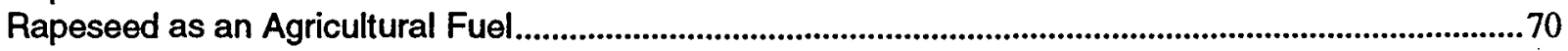

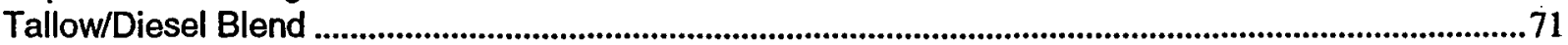

The Influence of Various Oxygenated Compounds on the Cetane Numbers of Fatty Acids and Esters

The Physical Characterization of Biodiesel/Low Sulfur Diesel Fuel Blends ...............................................73

Transesterification Process to Manufacture Ethyl Ester of Rape Oil...........................................................74

Vegetable Oils as Alternative Diesel Fuels.........................................................................................................75

Materials Compatibility, Fuel Blend Characteristics, Engine Dynamometer Evaluation .........................77

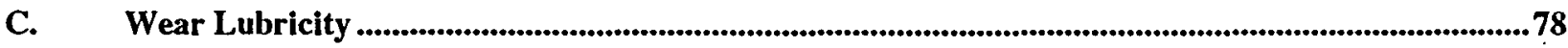

Biodiesel Lubricity Quantification - Low Blends................................................................................79

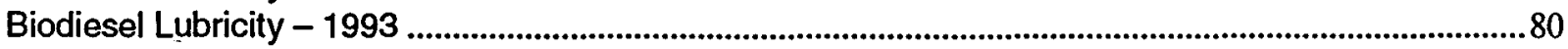

Engine Oil Literature Search and Summary ....................................................................................... 81

Program Management and Planning for Advanced Materials from Renewable Resources......................82

Small Engine Lubrication Oil Testing Two Cycle Outboard Engines......................................................8

The Relationship Between Fuel Lubricity and Diesel Injection System Wear .......................................8 84

Use of Biodegradable, Seed-Based, Automotive Engine and Transmission Lubricants, Industrial

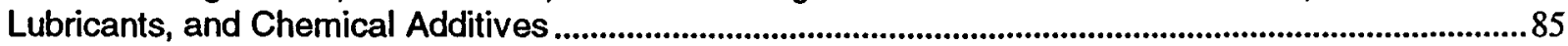

Use of Vegetable Oil as Fuel for Compression Ignition, Internal Combustion Engines............................86

Use of Seed-Based Lubricants as a Replacement for Petroleum Oil............................................................8 87

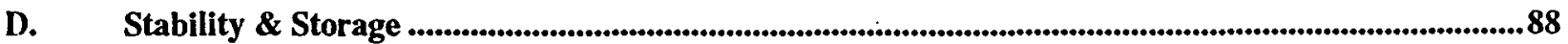

Biodiesel Blends in lowa Underground Storage Tanks..........................................................................89

City of Boston, Massachusetts Garage Retrofit with Biodiesel Tanks........................................................90

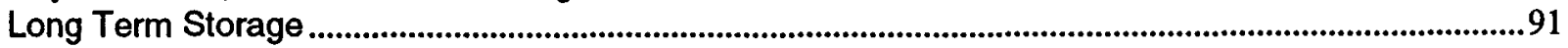

Thermal and Oxidative Stability ..................................................................................................................92

Two Year Storage Study with Methyl and Ethyl Esters of Rapeseed .......................................................93

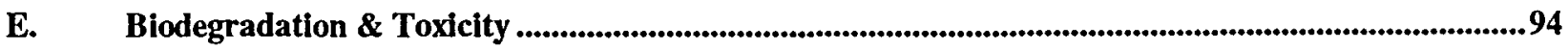

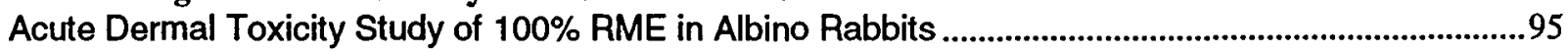

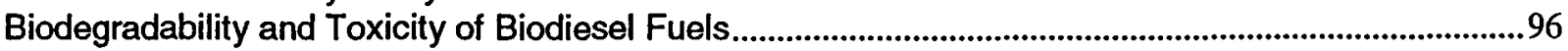

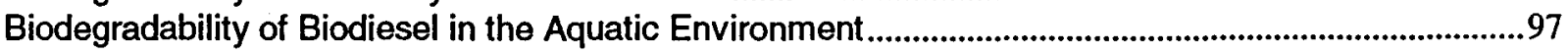

Biodegradation of Synthetic Diesel.....................................................................................................98

Toxicity of Particulate and Semi-Volatile Emissions from SME and Biodiesel Blended Fuels ............. 100

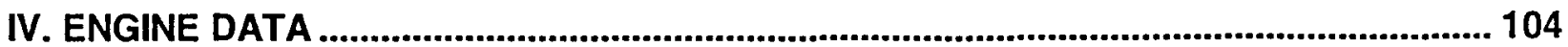


2-Cycle Engine 200 Hour EMA Test with Hydrogenated Soy Ethyl Ester (HySEE)

Alternative Fuels and Lubricants from Rapeseed Identification of Chemical Changes Occurring During the Transient Injection of Selected Vegetable Oils

Industrial Agricultural Products Center.

Monitor Biodiesel Use in Selected Tactical Vehicles at Yuma, Arizona..

Power, Emissions, and Bioresponse of Biodiesel in a Marine Environment.

A. Emissions.

Agricultural and Rural Transportation Systems

Biodiesel Blends in a DDC Series 60 Engine at High Altitude.

Bioblended Fuel for Use in Light-Duty Compression Ignition Engines.....................................................116

Biodiesel Steamboat Test on the Ohio River

Biodiesel Use in Underground Metal and Non-Metal Mines.

Biofuels Research

Chemical and Biological Characterization of Emissions from a Biodiesel-Fueled Underground Mining

Diesel Engine with and Without and Oxidation Catalytic Converter.

Comprehensive Emissions and Chemical Characterization of Rapeseed Oil-Derived Biodiesel......... 122

DDC 6V-71N Emission Testing on Diesel \& Biodiesel Blend.................................................................... 123

DDC 6V-92TA MUI Coach Upgrade Emission Optimization on $20 \% / 80 \%$ Soy/Diesel Blends .............. 124

Development of Biodiesel for Use in High-Speed Diesel Engines .........................................................125

Effects of an Oxidation Catalytic Converter and a Biodiesel Fuel on the Chemical, Biological and

Particle Size Characteristics of Emissions from an IDI Diesel Engine.

Effects of Methyl Esters of Tallow and Grease on Exhaust Emissions and Performance of a Cummins

L10 Engine.

Emission Characteristics of Methyl Soyate in Underground Mining Engines .

Emission Performance of Biodiesel Fuels in Heavy-Duty Pickup Truck.

Emission Performance of Selected Biodiesel Fuels as a Platform for Future Diesel Alternative

Evaluations.

Emissions and Engine Performance from Blends of Soya and Canola Methyl Esters with ARB \#2 Diesel in a DCC 6V92TA MUI Engine.

Emissions and Performance Characteristics of a 4-Stroke, Direct Injected Diesel Engine Fueled with

Blends of Biodiesel and Low Sulfur Diesel Fuel

Emissions Characteristics of Ethyl and Methyl Ester of Rapese................................... Culfur

Diesel Control Fuel in a Chassis Dynamometer Test of a Pickup Truck.

Emissions Characteristics of Soy Methyl Ester Fuels in an IDI Compression Ignition Engine.............. 136

Emissions Characteristics of Soy Methyl Ester Fuels in an Underground Mining Diesel Engine with and without Diesel Oxidation Catalyst Aftertreatment.

Emissions from Biodiesel Blends and Neat Biodiesel from a 1991 Model Series 60 Engine Operating at High Altitude.

Emissions Tests with an On-Road Vehicle Fueled with Methyl and Ethyl Esters of Rapeseed Oil..... 139 Engine Exhaust Emissions Evaluation of a Cummins L10E when Fueled with a Biodiesel Blend...... 140 Evaluation of Biodiesel in an Uiban Transit Bus Powered by a 1981 DDC8V71 Engine ...................... 142 Evaluation of Methyl Soyate/Diesel Blend in DDC 6V-92TA Engine: Optimization of NOx Emissions

........................................................................................................................................................................ 143

Field Trials of Soy Methyl Ester as a Fuel for Diesel Powered Equipment in Underground Mines ..... 144

Fueling Direct Injected Diesel Engines with 100\% Neat Biodiesel .........................................................146

Identification of Elements Found in Increased Soluble Fraction of Particulate Emissions with a Methyl

Soyate Blend.

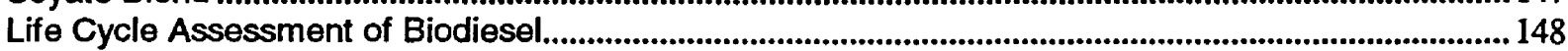

Massachusetts's Possible Biodiesel Use to Meet Emission Standards for Clean Air Act Compliance 150

Mechanisms of Emissions Reduction Using Biodiesel Fuels...................................................................... 151

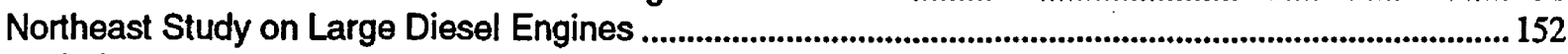

Optimize 20\% Methyl/Soyate \& Diesel Blend 1977 DDC 6V-71N Engine (Part-2) ................................ 153

Performance and Emission Characteristics of Tallow Ester, Ethanol and Diesel Fuel Blends in

Cummins N14-410 Diesel Engine. 


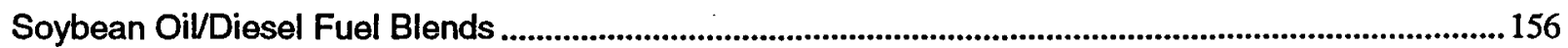

Technology for Efficient Use of Agricultural-Resources ........................................................................157

The Effect of Biodiesel Fuel Composition on Diesel Combustion and Emissions.................................. 158

Transient Emissions Testing of Biodiesel and Other Additives in a DDC Series 60 Engine.................159

Transient Emission Evaluation of Biodiesel Fuel Blend in a 1987 Cummins L10 and DDC 6V-92-TA

Transient Emissions from No. 2 Diesel and Biodiesel Blends in a DDC Series 60 Engine...

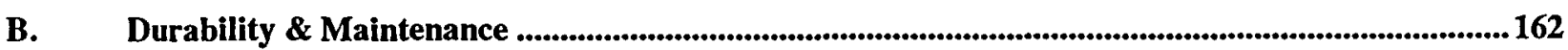

Biodiesel: A Partial Substitute for Diesel in Transit Buses ...................................................................163

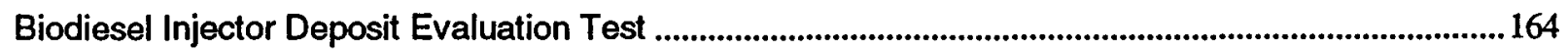

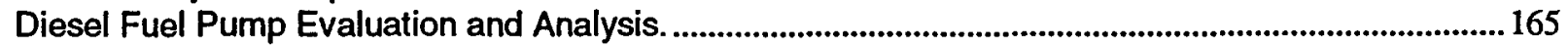

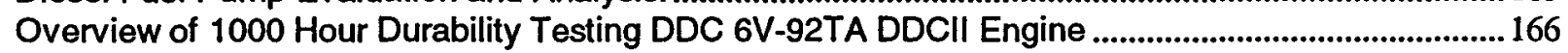

Performance of Biodiesel-Fueled Engines .............................................................................................167

Performance and Emissions of Vegetable Oil Hybrid Fuels ....................................................................168

Production and Testing of Ethyl and Methyl Esters Part II .................................................................169

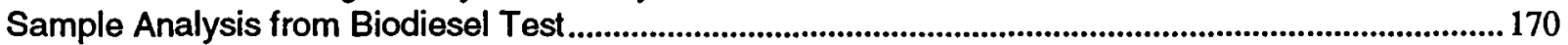

V. REGULATORY \& LEGISLATIVE ACTIVITIES ......................................................... 171

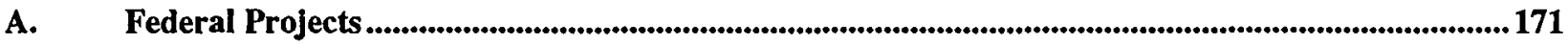

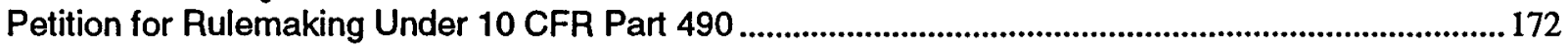

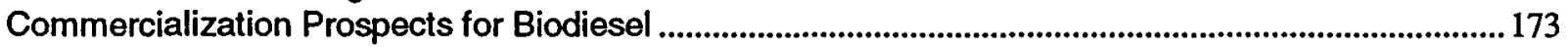

Congressional Research on Biodiesel Fuel .....................................................................................................174

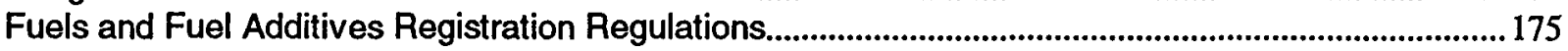

Manufacturing Incentives for Alternative Fuel Vehicles ....................................................................177

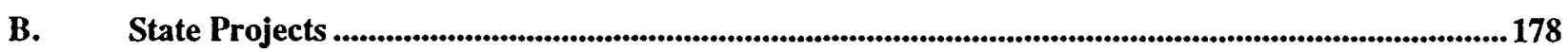

Summary of State Alternative Fuel Programs, Requirements, and Opportunities for Biodiesel .......... 179

VI. COMMERCIALIZATION ACTIVITIES .................................................................... 180

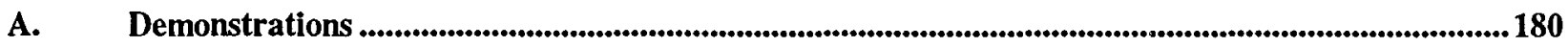

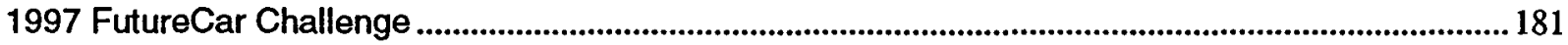

Biodiesel Demonstrations: Public Transit Systems and lowa Department of Transportation Heavy Duty

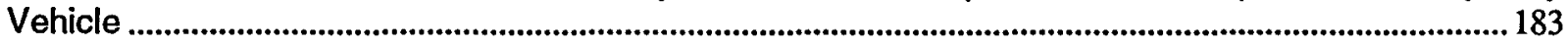

Biodiesel Fuel Evaluation for the U.S. Army Tactical Wheeled Vehicles ............................................... 184

Biodiesel Fuels Demonstration During the 1996 Olympics ...................................................................185

Biodiesel Research, Development and Demonstration Support.........................................................186

Biomass-Derived Alternatives in High Performance Snowmobile Engines: A Snowmobile in the Park

Bi-State Development Agency Alternative Fuel Bus Testing of 10 Buses................................................ 188

Boston, Massachusetts Bus Fleet Operating on Biodiesel ....................................................................... 190

Clean Air Partners-Biodiesel Water Shuttles at Logan Airport ............................................................191

Demonstrate 35 Percent Biodiesel Blends in Line Haul Tractors Using DDC Series 60 and Cummins

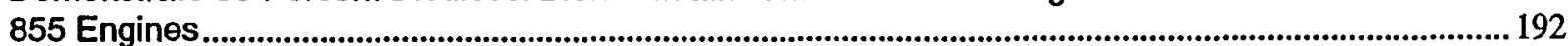

Demonstrate and Promote Biodiesel as a Transportation Fuel ..................................................................193

Demonstrate Biodiesel in Commuter Trains and Buses......................................................................194

Demonstration of the On-the-Road Use of Biodiesel...........................................................................195

Development of Rapeseed Biodiesel for Use in High-Speed Diesel Engines ....................................196

Expanded Rapeseed Ethyl Ester (REE) Demonstration and Testing, and Cooperative Development of

Hydrogenated Soy Ethyl Ester (HySEE) Biodiesel.....................................................................................197

Fueling Urban Buses with Soydiesel-Diesel Fuel Blending ....................................................................198

Hydrogenated Soy Ethyl Ester (HySEE) Production and Engine Durability Test Project ......................200 
lowa Heavy Vehicle Fleet Biodiesel Test at lowa Department of Transportation, Boone Maintenance

Facility 201

Massachusetts Biodiesel Shuttle System.................................................................................................................202

Methyl Ester Demonstration in Diesel Engines ..............................................................................................203

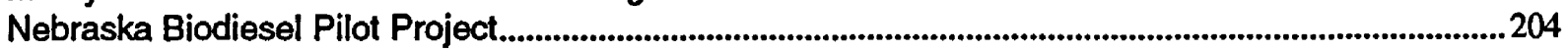

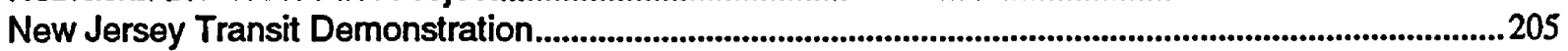

Omaha Nebraska Metro Transit Biodiesel Buses...................................................................................206

Over-the-Road Heavy-Duty Diesel Engine Operational Demonstration .................................................207

Pilot Demonstration of Biodiesel in Tourism-Related Transportation: A Truck in the Park...................208

Promotion of Agricultural Soydiesel Use in South Carolina ....................................................................209

Rhode Island Energy Office and Department of Transportation Ferry Boat Program .............................210

Soy-Diesel Blends' Use in Aviation Turbine Engines...................................................................................211

Tallow-Based Biodiesel Test at the Kansas City Area Transit Authority .....................................................212

The lowa Ames Transit Agency Biodiesel Bus Demonstration ................................................................213

Trash Truck and Bus B-20 Demonstration..........................................................................................................214

Twin Cities, Minnesota Biodiesel Pickup Truck Demonstration ...................................................................215

University of Minnesota Neat Biodiesel Pickup Demonstration and Outreach Project ..........................217

Virginia Biodiesel Bus Demonstration and Test Operation............................................................................218

Virginia Boat Operating on Biodiesel.......................................................................................................219

Waco and Washington, lowa Community School District School Bus Demonstrations Using Biodiesel

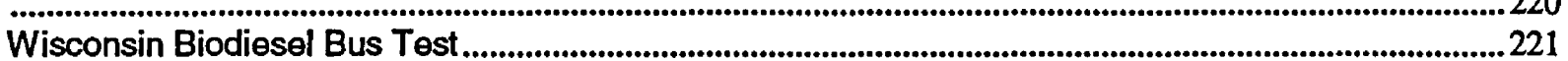

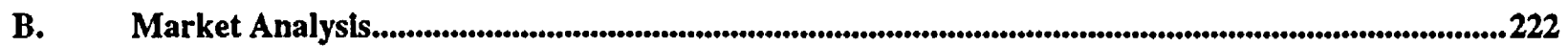

Biodiesel Market Opportunities and Potential Barriers .........................................................................223

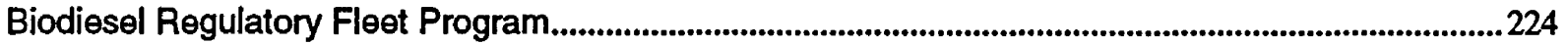

Combustion Analysis of Esters of Soybean Oil in a Diesel Engine ..........................................................225

Low Blend Level Test Market (Premium Diesel Market) ...........................................................................226

Market Opportunities for Diesel Technology..............................................................................................................227

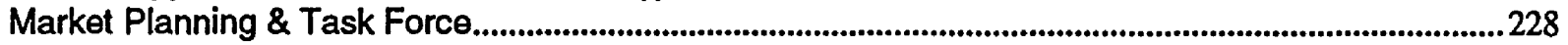

Non-Fuel Industrial Uses of Soybean Oil-based Esters..................................................................................2229

Potential Niche Markets for Biodiesel and their Effects on Agriculture ....................................................230

Biodiesel Research Progress: 1992 - 1997..........................................................................................231

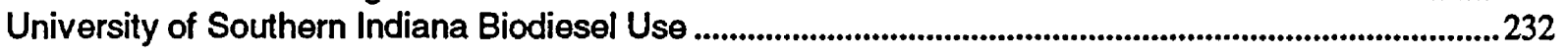

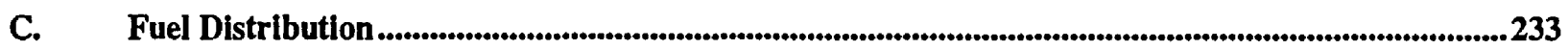

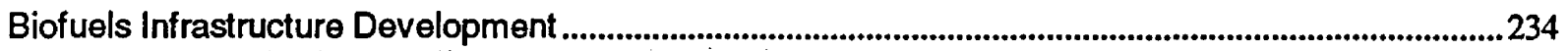

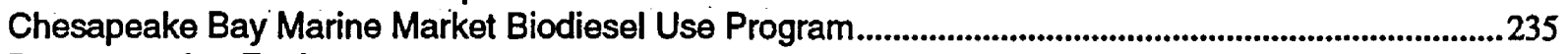

Demonstration Fuel........................................................................................................................................236

Marine Biodiesel and Education Project for San Francisco Bay and Northern California ......................237

Marine Biodiesel Use and Education.............................................................................................................238

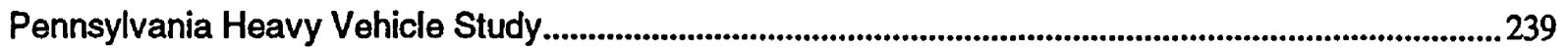

Regulated Fleets Marketing Assistance and Physically Market the Fuel ................................................240

Rhode Island Energy Office Education Program with Pleasure Craft .....................................................241

State of Massachusetts Commuter Boat Operation in Boston Harbor .......................................................242

Washington State Biodiesel Use in the Puget Sound ....................................................................................243

VII. ECONOMICS \& ENVIRONMENT .................................................................................. 244

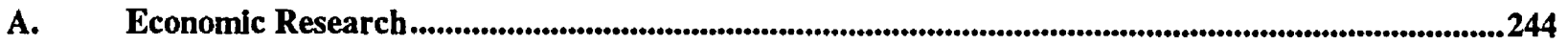

A Proposed Biodiesel Development Plan ........................................................................................245

An Analysis of Economic and Environmental Impacts of Using Biodiesel in the Kansas City

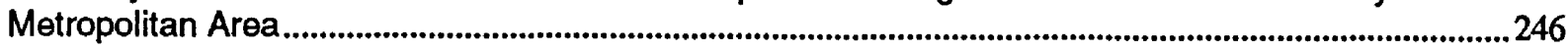

Assessment of the Potential for Biodiesel Rapeseed Production in the Southeast.................................247

Biodiesel From Canola: An Economic Feasibility Analysis ..................................................................248 
Biodiesel: Potential Economic Benefits to lowa and lowa Soybean Producers.......................................249

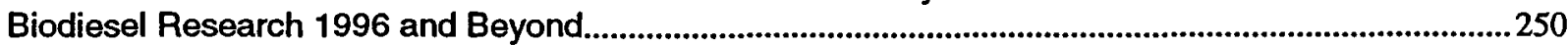

Compare Life Cycle Costs of Alternative Fuels (Biodiesel, Compressed Natural Gas, and Methanol in

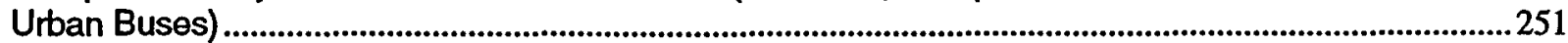

Conversion of Glycerol from SoyDiesel Production to 1,3 Propanediol................................................253

Economic Impacts of Biodiesel use in a Midwestern State Vehicle Fleet............................................254

Estimating Price and Nonprice Impact of Producing Biomass on CRP Acreage .................................255

Fuel Road Tax Investigation ................................................................................................................................25

Industrial Products from Agricultural Resources ......................................................................................258

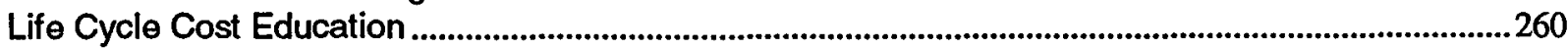

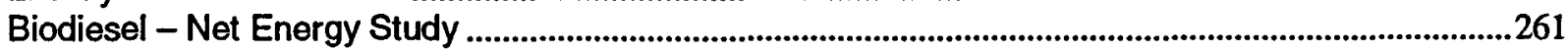

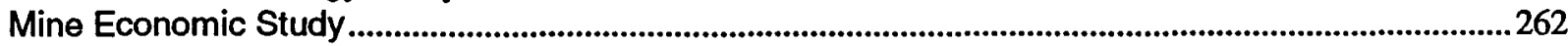

Oilseeds: Commercializing Biodiesel and Other Products.....................................................................263

Soy Diesel Processing Buchanan County, Missouri: Potential Impacts..............................................265

Tax Incentive Study ..................................................................................................................................266

Technoeconomic Analysis of Enzymatic Esterification of Highly Fatty Acid Feedstocks......................267

The Economic Feasibility of Community Based Biodiesel Plants ...............................................................2268

The Economics of Engine Replacement/Repair for Biodiesel Fuels ......................................................269

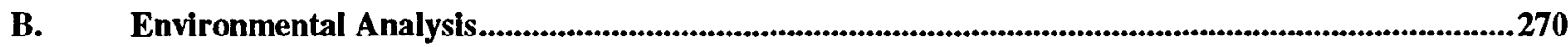

Biodiesel Parks \& Environmentally Sensitive Areas Market Pre-Evaluation Study ..............................271

Environmental Benefits of Biodiesel ..............................................................................................2 272

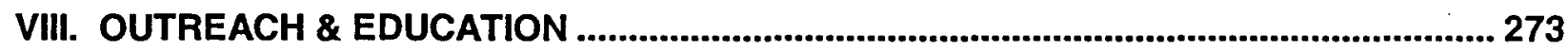

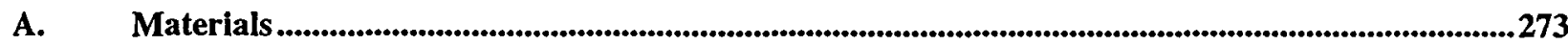

Transportation and Handling of Biodiesel and Biodiesel Blends........................................................2 274

Regulated Fleets - Core Communication ..............................................................................................22

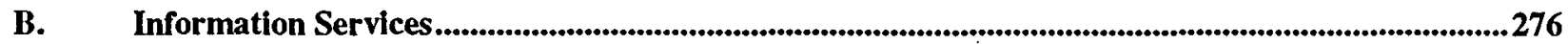

Biodiesel Awareness and Attitudes by Transit System Managers .........................................................227

Biodiesel Core Communications - "Biodiesel Report" ..............................................................................2278

Biodiesel Research at University of Georgia ....................................................................................279

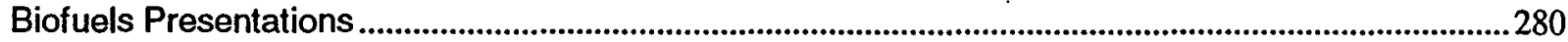

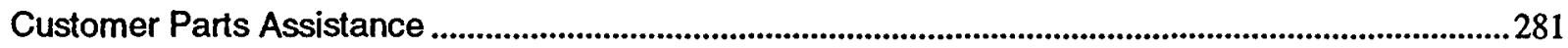

Establishment of a Biodiesel Consortium in Philadelphia .............................................................282

First Workshop: Commercialization of Biodiesel .............................................................................283

Government Fleets Biodiesel Option (FY 1996) ..............................................................................284

Industrial Uses of Agricultural Materials-Situation and Outlook Report (S\&O) ...................................285

Information Development, Maintenance and Distribution ..................................................................28

Research Needs Resulting from Experiences of Fueling of Diesel Engines with Biodiesel..................288

Second Workshop: Commercialization of Biodiesel, Environmental and Health Benefits....................289

Third Workshop: Commercialization of Biodiesel: Producing a Quality Fuel .......................................290

Troubleshooting Field Problems with Biodiesel.....................................................................................2291

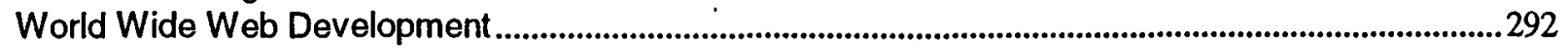

INDEX OF PROJECT TITLES.......................................................................................... 293

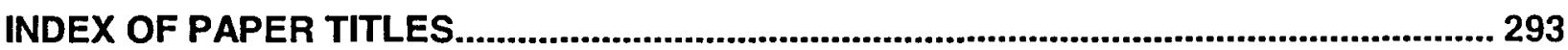

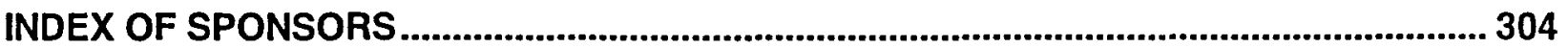

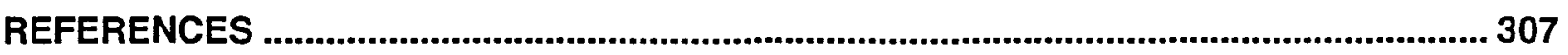




\section{Acknowledgments}

\section{By IRI}

Information Resources, Inc. gratefully acknowledges its sponsor at the U.S. Department of Energy, Dr. Raymond Costello and its technical monitor, Dr. K. Shaine Tyson, at the National Renewable Energy Laboratory. IRI also thanks Janine Finnell of DynCorp for her cooperation and patience in completing this project. The principal authors of this report wish to express their sincere gratitude to the endless support and guidance of Steve Howell and Alan Weber of MARC. Likewise, Bev Thessen, Information Manager for the National Biodiesel Board, deserves recognition for indulging the numerous questions and report requests necessary to complete a task of this order.

Finally, a special thanks goes to all those who willingly participated in this collection effort.

\section{By DynCorp}

The authors would like to acknowledge the efforts of Alan Weber, MARC-IV, who graciously provided input on a large number of the U.S. Department of Agriculture biodiesel project. A thanks also goes to David Pizzano of DynCorp's Energy Programs Group who helped to format the project information as well as review the document. Dr. Rene Tshiteya, Director, Planning and Analysis Center, assisted in reviewing and providing guidance as needed on the project. 


\section{Introduction and How to Use This Report}

\section{A. Introduction}

Since the oil shortage during the late 1970s, the United States has imported more than $\$ 50$ billion of oil annually, or $52 \%$ of its demand. Two-thirds of U.S. refineries have closed. Air pollution remains a threat to human health. Climate change has surfaced as a global concem requiring legally binding solutions. The U.S. farm economy continues to struggle for sovereignty.

For these reasons, the U.S. Department of Energy (DOE) Office of Fuels Development began evaluating the potential of various altemative fuels, including biodiesel, as replacement fuels for traditional transportation fuels. Biodiesel is derived from a variety of biological materials from waste vegetable grease to soybean oil. This alkyl ester could be used as a replacement, blend, or additive to diesel fuel.

This document, funded by DOE, is a comprehensive summary of relevant biodiesel and biodiesel-related research, development, demonstration, and commercialization projects completed and/or started in the United States between 1992 and 1997. This document was designed for use as a reference tool to those evaluating biodiesel's potential as a cleanbuming alternative motor fuel. It encompasses federally, academically, and privately funded projects.

DOE chose to review the past 5 years of research for the following three reasons. Research before 1992 revolved largely around vegetable oil, rather than esterified oil, as a direct replacement for diesel fuel. Further, alkyl ester research and development in the United States began with the formation of the National SoyDiesel Development Board (now called the National Biodiesel Board [NBB]) in 1992. More importantly, DOE anticipates that this compilation will serve as a foundation for the evolution of a 5-year strategy for biodiesel development and improve coordination for future research.

\section{B. How to Use This Report}

This report is a summary of biodiesel research completed from 1992 through 1997. To help the readers access the information included in this summary document, we have organized the subject matter by a number of search mechanisms.

The Table of Contents is the best place to begin. It contains headings and page numbers for all projects included in the report. Additional information on projects, papers, or sponsoring organizations can be found in the indexes. The indexes are broken down into three categories by Project Title, Paper Title, or Sponsoring Organization.

For information on a specific topic, begin by searching the Table of Contents. The projects are divided into sections and subsections. However, be aware that some projects may fall into more than one category. To find a project that fits into this classification, go to the lead page of that section or subsection for a list of papers that have been cross-referenced to that category. 
The index section is helpful if the name or approximate name of the project or paper is known. Although paper and project titles are often similar, both indexes should be checked in case the larger project has a different name than its primary paper.

The indexes are user friendly and very helpful for those with limited time. However, there is no substitute for taking the time to "thumb" through the entire document. The information included in this report is just a taste of the vast array of interesting work being done in the field.

As the authors sought input to this report, they were amazed by the sheer volume of projects in the area of biodiesel, with more than 350 projects identified. In earlier stages, the document was organized by project sponsors, but with the recommendation of NBB, the authors decided to organize it by topic to make it more useful to the reader. Seven categories of research were identified, including biodiesel production; fuel characteristics; engine data; regulatory and legislative activities; commercialization activities; economics and environment; and outreach and education. Numerous subcategories were further developed to guide a reader interested in more focused topics through the report; e.g., the engine data category is divided into emissions, durability, and maintenance activities. Overall, the largest volumes of biodiesel projects were conducted in the areas of biodiesel fuel properties, emissions data, and commercialization/ demonstration activities.

Although we have worked to make this report as comprehensive as possible, the following caveats apply. Time and budget constraints in any report require authors to set deadlines regarding additional submissions to finalize project data. In addition, despite our best efforts to seek input from leading biodiesel experts, inevitably in a document of this nature, some projects may be overlooked to the massive quantity involved.

As this report will be provided on a web site, we are examining the possibility of adding new project information as it becomes available. We invite you to contact the webmaster to express your opinion on whether it would be useful to update and expand upon this report as more biodiesel research is conducted in the future. 


\section{Production}




\section{Project Title:}

\section{Biofuel Coproduct Development}

Background: With increasing pressure on biomass using facilities to reduce costs and increase operating efficiency, coproduct development is being looked at more and more as a value-added opportunity worth examining more thoroughly.

\section{Objectives:}

- Lower the cost of biofuels through the sale of coproducts from biofuels production. The NRBP will assess the potential coproducts that are created as a result of the production process for biodiesel and ethanol.

- Additionally, NRBP will examine current and new industries that could emerge from ecoindustrial parks that demonstrate a synergy with biodiesel and ethanol production, such as low-cost electricity and steam in the case of ethanol, and glycerol in the case of biodiesel.

Status: The project has been postponed.

Accomplishments:

- The first step for this project will be to form a partnership with the biofuels industry and selected states to develop the scope of the study, which will identify coproducts and markets. To execute this project, a contractor will be retained.

Participants: U.S. Department of Agriculture, various states, Northeast Regional Biomass Program

Sponsoring Organization(s): U.S. Department of Energy Office of Fuels Development and Northeast Regional Biomass Program

Point of Contact: Richard Handley, Northeast Regional Biomass Program, CONEG Policy Research Center, Inc., 400 N. Capitol St., Suite 382, Washington, DC 20001, phone 518.899.9572, fax 518.899.9574, e-mail mandley@capital.net.

Papers: None available at this time 


\section{Project Title:}

Hydrogenated Soy Ethyl Ester (HySEE), Preliminary Processing and Screening Work

Background: Biodiesel made from rapeseed oil is very expensive, mostly because of the cost of rapeseed oil. Rapeseed oil is a commodity and has higher valued uses in addition to biodiesel; therefore, its price is largely set by those other markets. This makes it difficult to make biodiesel from rapeseed oil for less than $\$ 3.00 / \mathrm{gal}$. Even at this price, rapeseed oilbased biodiesel may have niche markets where its environmental benefits are of value.

Objectives: To conduct preliminary production and screening work on HySEE biodiesel fuel.

\section{Status: FY 1994-FY 1995}

Accomplishments: The project was completed in 1995 and the final report was submitted in September of the same year.

Participants: JR Simplot Company, Pacific Northwest and Alaska Regional Biomass Energy Program, and the University of Idaho

Sponsoring Organization(s): Pacific Northwest and Alaska Regional Biomass Energy Program

Point of Contact: Dr. Charles L. Peterson, Department of Agricultural Engineering, University of Idaho, Moscow, ID 83844; phone 208.885.7906, fax 208.885.8923, e-mail peterson@novell.uidaho.edu.

\section{Papers:}

Final Report: HySEE Preliminary Processing and Screening, Making and Testing a Biodiesel Fuel Made from Ethanol and Waste French-Fry Oil. July 1995. 


\section{A. Feedstocks}

Also see the following projects:

A Proposed Biodiesel Development Plan

Beef Tallow as a Biodiesel Fuel

Development of Rapeseed Biodiesel for Use in High-Speed Diesel Engines

Engine Oil Literature Search and Summary

Hydrogenated Soy Ethyl Ester (HySEE), Preliminary Processing and Screening Work

Oilseeds: Commercializing Biodiesel and Other Products

Promotion of Agricultural Soydiesel Use in South Carolina

Technoeconomic Analysis of Enzymatic Esterification of Highly Fatty Acid Feedstocks. 


\section{Project Title:}

Assessment of Biomass Feedstocks Suitable for the Production of Liquid Biofuels

Background: Past feedstock assessments conducted by NRBP have been order of magnitude studies of the potential from the entire region. This is the first time the NRBP has looked at feedstocks in a geographic area that would be representative of a single production facility. This is also the first time the NRBP has looked at the potential for low-cost waste materials suitable for the production of biodiesel.

\section{Objectives:}

- Identify all biomass feedstocks that would be suitable for liquid biofuels production. The feedstock assessment, funded by the NRBP, will cover a five-county area surrounding Pittsburgh, Pennsylvania.

- The scope of work for this project includes analysis of waste materials for use in biodiesel production, an analysis of the availability of feedstocks, storage and transportation considerations, and an assessment of future competing uses.

Status: March 31, 1997-December 31, 1997

Accomplishments:

- The project has been contracted and is slated for completion by December 31, 1997.

Participants: CT Donovan and Associates, Northeast Regional Biomass Program

Sponsoring Organization(s): Northeast Regional Biomass Program

Point of Contact: Richard Handley, Northeast Regional Biomass Program, CONEG Policy Research Center, Inc., 400 N. Capitol St., Suite 382, Washington, DC 20001, phone 518.899.9572, fax 518.899.9574, e-mail thandley@ capital.net.

Papers: None available at this time 


\section{Project Title:}

Biodiesel from Microalgae: Complementarity in a Fuel Development Strategy

Background: Biodiesel produces fewer pollutants than petroleum diesel and is virtually free of sulfur. These properties make biodiesel an attractive candidate to facilitate compliance with the CAAA-1990. This fuel is ordinarily considered to be derived from oilseeds, but an essentially identical biodiesel can be made from microalgae.

Objectives:

- Collect algal species from natural habitats

- Determine whether the collected specimens are able to tolerate the expected mass culture conditions and produce large quantities of lipids.

Status: 1993

\section{Accomplishments:}

- The successful operation of an Outdoor Test Facility in Roswell, New Mexico, to carry out an engineering design assessment was completed.

- Two ponds provided substantial information regarding microalgae growth rates in mass culture, $\mathrm{CO}_{2}$ utilization, and pond design parameters.

Participants: National Renewable Energy Laboratory

Sponsoring Organization(s): U.S. Department of Energy Office of Fuels Development

Point of Contact: Lewis M. Brown, National Renewable Energy Laboratory, 1617 Cole Blvd., Golden, CO 80401.

\section{Paper(s):}

Brown, L. (1993). Biodiesel From Microalgae: Complementarity in a Fuel Development Strategy. Proceedings of the First Biomass Conference of the Americas: Energy, Environment, Agriculture, and Industry, vol. I, August 30-September 2, 1993; Burlington, VT. Golden: The National Renewable Energy Laboratory; pp. 902-915. 


\section{Project Title:}

Close-Out of Microalgae Component of Biodiesel Program

Background: In FY 1996, DOE's Aquatic Species Program was closed out and staff was laid off or reassigned. In FY 1997, DOE asked NREL to develop a formal close out document summarizing 18 years of research. Further, the laboratory needed to find a permanent depository for the Microalgae Collection that had been developed during the course of the program's life. To meet these requests, contracts were set with previous program staff and other industry experts to summarize the project's research and accomplishments.

Objective: The objective of this project is to summarize the historical state of knowledge in microalgae research by documenting the selection of microalgae specimens and the genetic research associated with developing improved strains of microalgae.

Status: The project was initiated in February 1997 and is scheduled to be completed by March 1998 with the transfer of the algae collection. The closeout report should be available by early 1998.

Accomplishments: Work is in progress.

Participants: John Benemann, 343 Caravelle Drive, Walnut Creek, CA 94598, phone 510.939,5864; Teri Dunahay and John Sheehan, National Renewable Energy Laboratory, 1617 Cole Blvd., Golden, CO 80401-3393, phone 303.275.4420

Sponsoring Organization: U.S. Department of Energy Office of Fuels Development

Point of Contact: Dr. K. Shaine Tyson, National Renewable Energy Laboratory, 1617 Cole Blvd., Golden, CO 80401, phone 303.275.4616, fax 303.384.6877, e-mail

tysonk@tcplink@nrel.gov.

\section{Papers:}

Benemann, Dr. J., 343 Caravelle Drive, Walnut Creek, CA, 94598, phone 510-939-5864. Contract \# ACG-7-17031-01, Closeout Report for the Biodiesel from Aquatic Species Project, Part II: Outdoor Culture Collection and Process Engineering, 7/97-12/97, FY 1996.

Dunahay, Dr. T., P.O. Box 7485, Boulder, CO, 80306, phone 303.499.3715. Contract \#, ACG7-17030-01, Closeout Report for the Biodiesel from Aquatic Species Project Part I: Collection, Screening, and Improvement of Microalgal Strains, 3/97-12/97, FY 1997.

Roessler, P., San Diego, CA. proessler@msn.com. Contract \# AC0-17026-01, Maintenance and Screening of the National Renewable Energy Laboratory Algae Culture Collection, 4/973/98, FY 1996.

Zaborski, O., Univ. of Hawaii (tentative), 2540 Dole Street, Holmes Hall 246, Honolulu, HI 96822, phone 808.956.8146. Transfer of National Renewable Energy Laboratory Biofuel's Microalgae Collection to a Permanent Depository, other details to be determined. Anticipated period of performance 12/97-3/98. 


\section{Project Title:}

$\mathrm{CO}_{2}$ Mitigation in Fossil-Fueled Power Plants Using Microalgae with Co-Production of Biodiesel

Background: Microalgae are unique photosynthetic organisms in that they accumulate high levels of natural oils, thrive in high-salinity water, and use $\mathrm{CO}_{2}$ as their sole carbon source. Microalgae grown in ponds can be used to trap $\mathrm{CO}_{2}$ from power plant flue gas while providing a feedstock for biodiesel.

\section{Objectives:}

- Establish a technoeconomic model of microalgae production for $\mathrm{CO}_{2}$ mitigation with coproduction of biodiesel.

- The project also examined technology options for producing and evaluating biodiesel from low-cost feedstocks at the pilot scale.

\section{Status: FY 1995-FY 1996}

\section{Accomplishments:}

- A spreadsheet-based economic model was developed for microalgae production using $\mathrm{CO}_{2}$ from flue gases. This model predicts costs within $2 \%$ of those predicted by an earlier FORTRAN model, but is much easier to use. It has been used to assess targets for lipid content and growth rate of genetically engineered algae.

- The final project report (1996) reviews the current state-of the-art, including algal cultivation and harvesting-processing, and outlines a technique for achieving very high productivity.

- Costs of $\mathrm{CO}_{2}$ mitigation with microalgae production of oils ("biodiesel") are estimated and future R\&D needs outlined.

Participants: National Renewable Energy Laboratory, Pittsburgh Energy Technology Center, Dr. John Benemann

Sponsoring Organization (s): U.S. Department of Energy Office of Fuels Development and U.S. Department of Energy Pittsburgh Energy Technology Center.

Point of Contact: Karin Kadam, National Renewable Energy Laboratory, 1617 Cole Blvd., Golden, CO 80401-3393, phone 303.384.6866; Dr. Perry Bergman, U.S. Department of Energy, Pittsburgh Energy Technology Center, phone 412.892.4890.

\section{Papers:}

Benemann, J.R., Oswald, W.J. (1996). Systems and Economic Analysis of Microalgae Ponds for Conversion of $\mathrm{CO}_{2}$ to Biomass. Final Report submitted to the Department of Energy, Pittsburgh Energy Technology Center under Grant No. DE-FG22-93PC93204.

Benemann, J.R. (1996). " $\mathrm{CO}_{2}$ Capture and Biofuels Production with Microalgae." Proceedings of Eleventh Annual Coal Preparation, Utilization, and Environmental Control Contractors Conference, Pittsburgh, PA. pp. 199-206.

Zeiler, K.G., D.A. Heacox, S. Toon, K. Kadam, and L.M. Brown (1995). "The Use of Microalgae for Assimilation and Utilization of Carbon Dioxide from Fossil Fuel-Fired Power Plant Flue Gas." In Energy Conversion Management, Elsevier Science Ltd., vol. 36, pp. 707712. 
Kadam, K.L. (1995). Power Plant Flue Gas as a Source of $\mathrm{CO}_{2}$ for Microalgae Cultivation: Technology and Economics of $\mathrm{CO}_{2}$ Recovery and Delivery.

Kadam, K.L. (1994). Engineering Analysis of Microalgae Technology with Recommendations for Laboratory Research. Milestone Report, December.

Brown, L.M., K.G. Zeiler, S.G. Talbot, and D.A. Heacox (1994). "Photosynthetic Conversion of $\mathrm{CO}_{2}$ to Biomass." Proceedings of the 10th Annual Coal Preparation, Utilization, and Environmental Control Contractors Conference, Pittsburgh, PA. vol. II, pp. 557-561.

Chelf, P., L.M. Brown, and C.E. Wyman (1993). "Aquatic Biomass Resources and Carbon Dioxide Trapping." Biomass and Bioenergy, 4:175-183. 


\section{Project Title:}

Developing Yellow Mustard (Sinapis Alba L.) Cultivators Suitable for Biodiesel Production in the United States

Background: A diallel crossing design will be used to examine the inheritance of biodiesel quality characters. New germplasm and cultivators will be developed using variations created, and manipulated, by backcrossing and recurrent selection. Sufficient neat yellow mustard oil will be expelled for conversion to both ethyl and methyl ester biodiesel. A complete set of fuel properties will be collected on yellow mustard methyl and ethyl ester. Short-term engine torque test and engine-mapping test will be conducted on a John Deere 4239T diesel engine connected to an electric cradle dynamometer. Long-term engine tests will be performed in accordance with the 200-h screening test for alternative fuels. An economic analysis will draw from data generated on test plots and from on-farm production of yellow mustard. A survey of farmers who have grown mustard in the Pacific Northwest will be conducted. Other crops grown in the area that have similar tillage, seeding and harvesting requirements will provide input estimates for production. Farm budgets prepared by the Department of Agricultural Economics and Rural Sociology at the University of Idaho will be used as a starting place for the cost analysis.

\section{Objectives:}

- Determine the inheritance of desirable fatty acid profile, high oil content, and low glucosinolate content in yellow mustard and hence develop cultivators of yellow mustard suitable for biodiesel production at low cost and with low crop inputs

- Develop and refine a transesterification process for producing biodiesel from yellow mustard for fuel characterization, engine performance testing, and other tests

- Collect data from on-farm tests and farmers field crops regarding inputs and seed yield potential of yellow mustard and integrate new data on yield and input cost to update oil cost analyses and hence estimate cost of mustard biodiesel production.

Status: September 1996-August 1996.

\section{Accomplishments:}

- F1 seed was produced from a diallel crossing design where high oil content, yellowmustard lines were inter-mated with low glucosinolate and high erucic acid breeding lines.

- Additional segregating populations derived from earlier experiments were selected (using a half seed procedure) for industrial oil characteristics and for seed meal quality.

- Seed from more than 400 selections were increased in the greenhouse over winter and seed will be available for field adaptability trials in 1997.

- A breeding selection with feed quality seed meal was increased and will be crushed in 1997 to produce mustard oil biodiesel for engine performance tests.

Participants: Plant Soil \& Entomological Science, University of Idaho

Sponsoring Organization(s): CRGO, Idaho

Point of Contact: J. Brown, Plant Soil \& Entomological Science, University of Idaho, Moscow, ID 83844-2040, phone 208.885.7078.

Papers: Brown, J. (1996). "Developing Canola Quality Cultivators from Yellow Mustard. In Proceedings of the Pacific Northwest Canola Meeting, Great Falls, Montana, November 1996. 


\section{Project Title:}

Multifeedstock Biodiesel Project (in earlier phase, the project was titled "Cost-Effective Options for Testing of Biodiesel from Low-Cost Feedstocks)

Background: This project explores the issues associated with producing biodiesel from lowcost feedstocks, including animal rendering wastes and recycled cooking oils. Central research issues include modifications to production technology, cost trade-offs, characterization and performance of the biodiesel fuel and blends with petrodiesel, and demonstration trials. In the early phases of this project, a research facility was envisioned, where various technological options could be explored. As the project evolved, a private entrepreneur volunteered to construct the facility to produce these experimental biodiesel fuels. The project is currently in Phase III.

Objectives: Project work has occurred in three phases as follows:

- Phase 1: Determine the goals and objectives of a pilot plant and develop the activities list, time line, and costs for Phase II.

- Phase II: This phase identified all major activities required to determine the commercial feasibility of producing and selling biodiesel made from low-cost feedstocks, e.g., equipment/technology for the plant, equipment sizing and scale-up considerations, facility needs (utilities, storage), analytical needs, timetables, personnel needs, total project cost, and other items.

- Phase III: This phase is now focused on production deployment issues for biodiesel produced from recycled (waste) fats and oils. This phase involves producing, testing, and characterizing emissions from biodiesel production from eight feedstocks. The main objective is to determine ways to reduce the cost of biodiesel using new, lower-cost feedstocks and through lowering processing costs. Specific tasks follow:

- Laboratory tests will be conducted to establish the properties and characteristics of neat biodiesel from winter yellow grease, summer yellow grease, beef tallow (edible and non-edible), pork lard, acidulated soapstock, soybean oil, and rapeseed oil. The project will establish data on fuel characteristics that can be used to support feedstockneutral specifications for biodiesel.

- The neat biodiesel will be blended with petro-diesel in 20:80 proportions for EPA emission testing using a DDC series 60 bus engine. The data gained will be used to develop a report for EPA.

- Columbus Foods of Chicago is constructing a production facility and will produce the fuels used in the demonstration portion of the project. Fuel field demonstrations will be done in cooperation with American Sightseeing - Chicago, a major transport operator with previous experience in biodiesel field trials. The company will provide six buses for biodiesel testing and two control buses. Each bus is expected to accrue 30,000 miles annually.

- The project hopes to stimulate production and further research activity for the industry.

Status: The first phase of the project began in 1994. The second phase was completed in April, 1997. The third phase of the Multi-feedstock Biodiesel Project was initiated in April, 1997, and is off to a slow start. Columbus Food started plant shakedown in August 1997 and anticipates full production status for soy methyl esters by late 1997. Producing the waste grease and tallow/lard methyl esters may require further facility or process modifications. Chemol is preparing feedstocks for the engine-testing component of the project, which should 
commence by late 1997. Other fuel suppliers have offered to supply the demonstration fuels until Columbus Food begins production. Institute of Gas Technology is still negotiating with the initial demonstration fleet. If negotiations are unsuccessful, other fleets are under consideration. The project contract runs until April 1998 with a likely 6-month extension.

\section{Accomplishments:}

\section{Phase II}

- This phase produced a comprehensive report detailing the best method to meet the goals of the Multifeedstock Biodiesel Project. Selected biodiesel facilities in Europe are described in detail, and several economic feasibility scenarios are presented.

- A variety of technology options is currently available to effectively process biodiesel with free fatty acids up to $5 \%$.

- Although technology to handle 10\%-15\% levels of free fatty acids in the feedstock are available, they are fewer in number and need additional optimization. Furthermore, the technologies to process $10 \%-15 \%$ levels of free fatty acid are not commercially available.

- Most used restaurant grease is below $15 \%$ free fatty acid, and with technology to process them, these materials are now viable feedstocks for biodiesel production.

\section{Phase III}

- Sightseeing of Chicago agreed to participate in the project using its own buses.

Participants: National Renewable Energy Laboratory, Institute of Gas Technology, Chemol Co. Inc, Colorado Institute for Fuels and Engine Research; Systems Lab Services, Sightseeing of Chicago; Columbus Foods of Chicago, National Biodiesel Board, Fats and Protein Research Foundation, Inc; American Sightseeing Bus Company; Illinois Soybean Association; Chicago Clean Cities; and City of Chicago.

Sponsoring Organization(s): U.S. Department of Energy Office of Fuels Development, Fats and Protein Research Foundation, Inc, Illinois Soybean Checkoff Board, and National Biodiesel Board.

Point of Contact: Dr. K. Shaine Tyson, National Renewable Energy Laboratory, 1617 Cole Blvd., Golden, CO 80401, phone 303.275.4616, fax 303.275.4675, e-mail tysonk@tcplink.nrel.gov.

\section{Papers:}

Multi-Feedstock Biodiesel Project Phase II--Final Report

Phase III reports (forthcoming) 


\section{Project Title:}

Potential Feedstock Supply and Costs for Biodiesel Production

Background: America imports nearly $50 \%$ of its petroleum, which results in a negative trade balance of approximately $\$ 50$ billion per year. In addition, there has been growing concem over the economic, energetic, and environmental aspects related to the use of fossil fuels as a fuel source in combustion engines. Biodiesel has been demonstrated in unmodified diesel engines and has shown a reduction in the exhaust emissions of HC, PM, smoke, CO, and sulfur. Agriculturally derived fuels and/or waste-derived by-products from the food industry have potential to ease the United States' dependence on imported petroleum and at the same time provide a means of alleviating some of the economic and environmental concems this country faces.

\section{Objectives:}

- Assess the resource available for each biodiesel feedstock in terms of production and consumption as well as location of generation to determine potential biodiesel production from each feedstock

- Evaluate the economic feasibility of producing biodiesel subject to cost sensitivities of feedstock and chemical price, by-product credit and capital costs.

\section{Status: Completed}

Accomplishments:

- Beef tallows and waste frying oils are less expensive than soybean oil, and could represent an effective option to reduce the cost of biodiesel as well as extending the supply of biodiesel.

- The most important factor in biodiesel break-even price was feedstock cost.

- The amount of petroleum-based diesel fuel consumed in the United States is much greater than the potential of biodiesel from vegetable oils, tallows and waste greases.

- Although biodiesel blends are more expensive than petroleum diesel, the total costs may be the lowest of all the altemative fuels even under the worst-case biodiesel price.

- Biodiesel may best fit within defined areas where the use of cleaner buming altemate fuels is required, or where the other benefits of biodiesel are important.

Participants: Kansas State University; MARC-IV Consulting, Inc; and University of Missouri

Sponsoring Organization(s): Kansas State University; MARC-IV Consulting, Inc; and University of Missouri

Point of Contact: Steve Howell, MARC-IV Consulting, Inc, 16200 Northridge Road, Keamey, MO, 64060, phone 816.635.5772, fax 816.635.4836, e-mail showell@marciv.com.

Paper(s):

Nelson, R.G.; Howell, S.A.; Weber, J.A. (1994). "Potential Feedstock Supply and Costs for Biodiesel Production." Proceedings of the 6th National Bioenergy Conference, vol. I, Bioenergy '94, Reno-Sparks, NV. Western Regional Biomass Energy Program; pp. 59-66. 


\section{Project Title:}

Prevailing Markets for Biodiesel Feedstocks--An Empirical Overview

Background: Oil crops in the United States that may make good candidates for biodiesel production include soybean, com, cottonseed, sunflower seed, peanut, canola, industrial rapeseed, flaxseed, and safflower. Soybean oil accounts for about $75 \%$ of the nation's crop oil production, with farmers producing about 15 billion pounds annually. Com is the secondlargest source of U.S. crop oil, with about 2 billion pounds of oil produced each year. However, many minor oil crops have a relatively high oil content and could become ideal feedstocks for biodiesel. Most crop oils is sold in food markets, but a fair amount is sold for industrial purposes. Animal fats and waste grease such as tallow, lard, and yellow grease can be used to make biodiesel. There is an abundant supply of these materials--almost 9 billion pounds are produced each year in the United States.

The total U.S. supply of crop and waste oil--about 28 billion gallons--is only a fraction of the U.S. annual demand for transportation diesel fuel. Furthermore, the price of diesel fuel (about $\$ .60 / \mathrm{gal}$ ) is much lower than crop oil prices, which range from $\$ 1.73 / \mathrm{gal}$ to $\$ 4.85 / \mathrm{gal}$. The market price for animal fats and waste grease ranges between $\$ 1.19 / \mathrm{gal}$ to $\$ 1.29 / \mathrm{gal}$, which is less than the price of crop oils but still significantly higher than petroleum diesel. Given the prevailing market prices for these feedstocks, their use for biodiesel will be limited to niche markets where premium prices are paid for fuels with preferred environmental qualities.

Objectives: This study will examine oil crop (soybean, com, cottonseed, sunflower seed, peanut, canola, industrial rapeseed, flaxseed, and safflower) production as well as animal fats and waste greases to determine how their use for biodiesel might impact food and industrial markets.

Status: Initiated in FY 1997

Accomplishments: Study in process.

Participants: U.S. Department of Agriculture

Sponsoring Organizations(s): U.S. Department of Agriculture-Economic Research ServiceOffice of Energy and New Uses

Point of Contact: Dr. James A. Duffield, Agricultural Economist, USDA-Economic Research Service-Office of Energy and New Uses, 1301 New York Ave, NW, Room 1212, Washington, DC 20005, phone 202.501.6255, fax 202.501.6883.

Papers: Prevailing Markets for Biodiesel Feedstocks--An Empirical Overview (in process). 


\section{Project Title:}

Rapeseed Oil as a Fuel for Agriculture

Background: New cultivators of rapeseed will be developed with emphasis toward improved yield, winter hardiness, oil quality, and acceptability for use as fuels and coproducts. Improved production practices to enhance profitability will be studied. New and novel methods for processing oil into biodiesel, environmentally friendly lubricants, and other products will be developed. These new fuels will be tested for effect on engine durability, on materials, and the environment. Economic costs and retums associated with rapeseed production for these new uses will be evaluated.

Objectives: To generate information on:

- Higher yielding rapeseed cultivators with fatty acid composition suitable for diesel fuel and coproducts

- More efficient and environmentally acceptable processes for converting rapeseed oil to diesel fuel and associated coproducts

- More efficient methods and technology for storing, handling, and utilizing diesel fuel from rapeseed

- Economic costs and potential benefits associated with producing and using rapeseed oil as a fuel extender.

Status: This project was initiated in September 1992 and is scheduled to be completed by August 1997.

\section{Accomplishments:}

- The on-farm biodiesel plant expressed $22,500 \mathrm{~kg}$ of rapeseed in 1996 resulting in $9,710 \mathrm{~L}$ of oil. More than 18,900 L of biodiesel, all but 2,000 L with ethanol, were produced, of which 6,358 $\mathrm{L}$ was from used oil and 6,124 $\mathrm{L}$ for our joint project with Yellowstone Park. Biodiesel produced from the used hydrogenated soy oil is usable as a fuel but has a high pour point, which makes it a challenge for use in cold weather without special precautions for keeping the fuel liquid.

- Tests are continuing with three of the on-road vehicles. The 1992 Ford reached 76,985 miles; the 1994 Dodge 56,852 miles; the 1995 Dodge about 60,000 miles; and the 1992 diesel vehicle--operated by IDWR Energy Division--completed the 100,000 mile milestone. The engine was removed from the truck and sent to Cummins Engine Co. for evaluation. The engine showed fewer deposits and less wear than a similar engine operated on diesel, according to company personnel, although it was also judged slightly loaded.

- Acute oral toxicity limit tests showed that RME and REE (biodiesel) had LD50 values greater than $5,000 \mathrm{mg} / \mathrm{kg}$ and acute dermal toxicity tests showed LD50 values greater than $2,000 \mathrm{mg} / \mathrm{kg}$. The biodegradability and biodegradation rates of several biodiesel fuels in the aquatic environment show that all biodiesel fuels are readily biodegradable. After 28 days all biodiesel fuels were $77 \%-89 \%$ biodegraded; diesel fuel was only $18 \%$ biodegraded.

Participants: Department of Biological and Agricultural Engineering, University of Idaho

Sponsoring Organization(s): U.S. Department of Agriculture-Cooperative State Research, Education, and Extension Services 
Point of Contact: Dr. Charles Peterson, Department of Agricultural Engineering, University of Idaho, Moscow, ID 83844, phone 208.885.7906, fax 208.885.8923, e-mail peterson@novell.uidaho.edu.

\section{Papers:}

Peterson, C.I., D.I. Reece, J.C. Thompson, S.M. Beck, and C. Chase (1996). "Ethyl Ester of Rapeseed Used as a Biodiesel Fuel - A Case Study." Biomass and Bioenergy 10(5/6):331336.

Peterson, C.L. and D.L. Reece (1996). "Emissions Testing with Blends of Esters of Rapeseed Oil Fuel with and without a Catalytic Converter." SAE Technical paper No. 961114. SAE, Warrendale, PA 15096-0001.

Peterson, C.L. et al. (1996). "Engine Performance and Emissions with Methyl and Ethyl Esters of Rapeseed Oil." Proceedings of the 3rd Liquid Fuel Conference, ASAE, St. Joseph, MI 49085-9659, pp. 116-127.

Thompson, J.C., C.L. Peterson, D.L. Reece, and S.M. Beck (1996). "Two Year Storage Study with Methyl and Ethyl Esters of Rapeseed." Proceeding of the 3rd Liquid Fuel Conference, ASAE, St. Joseph, MI 49085-9659, pp. 104-114.

Reece, D.L., X. Zhang, and C.L. Peterson (1996). "Environmental and Health Effects of Biodiesel." Proceeding of the 3rd Liquid Fuel Conference, ASAE, St. Joseph, M/ 49085-9659, pp. 166-176.

Peterson, C.L. and D.L. Reece (1996). "Emissions Characteristics of Ethyl and Methyl Ester of Rapeseed Oil Compared with Low Sulfur Diesel Control Fuel in a Chassis Dynamometer Test of a Pickup Truck." TRANS. of ASAE 39(3):805-816.

Additional Information: CRIS Accession No. 9147024 


\section{B. Conversion}

Also see the following projects:

Alternative Fuels and Lubricants from Rapeseed

Rapeseed Oil as a Fuel for Agriculture 


\section{Project Title:}

Biodiesel by Indirect Liquefaction

Background: A process is presented to produce an equivalent of No. 2 diesel fuel from a variety of cellulosic materials. More than 100 materials have been tested in the biomass categories of industrial wastes, agricultural residues, forest wastes, and energy crops. The benefits of a "clean diesel" are therefore retained with energy performance comparable to diesel derived from petroleum. The applicability of the process to virtually any biomass source offers advantages in economy of scale and geographical distribution.

Objective: To determine whether indirect liquefaction is a viable option for converting biomass materials into high-quality products.

Status: Completed

\section{Accomplishments:}

- Indirect liquefaction offers a viable option for converting a variety of biomass materials into high-quality products.

- Near-term implementation of the technology will be limited to low or negative value feedstocks that present a disposal problem by alternative methods.

- With eventual rising costs of petroleum feedstocks, the potential application base should expand considerably.

Participants: Arizona State University, Department of Chemical Bio \& Materials Engineering

Sponsoring Organization(s): U.S. Department of Energy, U.S. Department of Agriculture, and U.S. Environmental Protection Agency

Point of Contact: Stephen Ochs, Department of Chemical Bio \& Materials Engineering, Arizona State University, Tempe, AZ 85287-6006.

Paper(s):

Ochs, S.; Sichz, T.; Kuester, J.L. (1994). "Biodiesel by Indirect Liquefaction." Proceedings of the 6th National Bioenergy Conference, vol. I, Bioenergy '94, Reno-Sparks, NV. Westem Regional Biomass Energy Program, pp. 27-34. 


\section{Project Title:}

\section{Conversion of Natural Glycerides to Higher Value Products}

Background: Animal fats and vegetable oils may be converted into derivatives called esters. Such esters are being evaluated worldwide as altematives to petroleum-derived diesel fuel. These esters, commonly called biodiesel, offer an environmentally sound replacement or extender for conventional diesel fuel. Nevertheless, current chemical technology for biodiesel production needs improvement to make biodiesel cost competitive with the conventional fuel while preserving the fuel characteristics needed for use in cold weather. Typically, biodiesel is prepared by esterification of the fat or oil feedstock with methyl alcohol under alkaline conditions. The resulting methyl esters are cleaned of their coproduct, glycerol, and isolated as biodiesel. This project is looking at another conversion technology, esterification of the catalytic action of lipase enzymes.

\section{Objectives:}

- Research an altemative, enzymatic approach for biodiesel production to produce biodiesel cost effectively from inexpensive feedstocks.

- Affect favorable low-temperature properties to biodiesel derived from two neglected and inexpensive feedstocks, animal fat and recycled restaurant grease.

- Foster the marketing of biodiesel as a replacement or extender of its petroleum-derived counterpart.

Status: FY 1992-1997.

\section{Accomplishments:}

- The low-temperature properties of several nomal and branched chain alkyl esters derived from tallow and recycled greases were determined for both the neat esters and as $20 \%$ ester blended in No. 2 low-sulfur diesel fuel. Comparisons were to diesel fuel itself.

- In general, the branched-alkyl esters of tallow showed significantly improved cold temperature properties over the normal-alkyl esters of tallow.

- Ethyl tallowate had the most promising properties both neat or blend in diesel fuel for the homologous normal series methyl to n-butyl.

- For the grease studied, both the normal and branched alkyl ester derivatives were improved over corresponding tallow esters, especially when tested neat. The coldtemperature properties of the $20 \%$ blend of the alkyl esters in diesel fuel were similar to neat diesel fuel.

- For the neat alkyl esters of grease, cold-temperature properties were comparable to or better than the esters of the more established feedstocks.

- An HPLC method was developed for quantifying neutral lipid classes: desired alkyl esters and undesirable free fatty acids, triglycerides, 1,2- and 1,3-diglycerides, and 1(2)monoglycercides.

Participants: Agricultural Research Service-North Atlantic Area, Eastem Regional Research Center

Sponsoring Organization(s): U.S. Department of Agriculture-Agricultural Research Service

Point of Contact: Thomas A. Foglia, Eastem Regional Research Center, Wyndmoor, PA 19038, phone 215.233.6480, fax 215.233.6795, e-mail tfoglia @arservc.gov. 
Papers:

Nelson, L. A., T.A. Foglia, and W. N. Marmer (1996). "Lipase-Catalyzed Production of Biodiesel." Journal of the American Oil Chemists' Society, 70:1191-1195.

Foglia, T.A., L. Nelson, R.O. Dunn, and W. N. Marmer (1996). "Low-Temperature Properties of Alkyl Esters of Tallow and Grease." Joumal of the American Oil Chemists.

Foglia, T.A., K.C. Jones, and W. N. Marmer (1996). "Quantitation of Neutral Lipid Mixtures by High Performance Liquid Chromatography with Light Scattering Detection." Joumal of the American Oil Chemists' Society.

Foglia, T.A., K.C. Jones, and W. N. Marmer (1996). "Production of Biodiesel, Lubricants and Fuel and Lubricant Additives." U.S. Patent Application 08/631,498, filed April 12, 1996.

Nelson, L.A., T. A. Foglia, and W. N. Marmer (1995). "Alternative Approaches to the Production of Biofuels." 1995 Annual Meeting, Journal of the American Oil Chemists' Society, San Antonio, TX, May 1995.

Nunez A. and G.J. Piazza (1995). "Analysis Of Lipoxygenase Kinetics by High Performance Liquid Chromatography with a Polymer Column." Lipids 30:129-133.

Piazza, G.J. and A. Nunez (1995). "Oxidation of acylglycerols and phosphoglycerides by soybean lipoxygenase." Journal of the American Oil Chemists' Society. 72:463-466.

Piazza, G.J. and M.B. Medina (1995). "Enzyme Assisted Formation of Fatty Acid Hydroperoxide." IN: Kader, J.-C. and Mazliak, P. (eds.), Plant Lipid Metabolism, Kluwer Academic Publication, Dordrecht, The Netherlands, pp.289-29.

Nunez, A., T.A. Foglia, and G.J. Piazza (1995). "Improved Method for Extraction of Hydroperoxide Lyase from Chlorella." Biotech. Techniques 9:613-616.

Piazza, G.J. and A. Nunez (1995). "Examination of the Action of Soybean Lipoxygenase-1 on Acylglycerols and Phosphoglycerides." Inform 6:524.

Nunez, A. and G.J. Piazza (1995). "Analysis of Lipoxygenase Multiple Substrate Kinetics by Reverse-Phase HPLC with a Polymer-Based Column." Inform 6:523.

\section{Presentations:}

Foglia, T.A., G.H. Knothe, L.A. Nelson, R.O. Dunn, W.N. Marmer, and M.O. Bagby (1996). "Improving the Properties of Vegetable Oils and Fats for Use as Biodiesel." World Conference and Exhibition on Oilseed and Edible Oils Processing, Istanbul, Turkey, October.

Nelson, L.A., T.A. Foglia, R.O. Dunn, and W.N. Marmer (1996). "Production and LowTemperature Properties of Alkyl Esters of Triglycerides as Biodiesel Fuels." Bioenergy '96-The 7th National Bioenergy Conference, Nashville, TN, September.

Nelson, L.A., T.A. Foglia, R.O. Dunn, and W.N. Marmer (1996). 1996 Annual Meeting, American Oil Chemists' Society, Indianapolis, May. 
Nelson, L. (1995). "Future Developments in Biodiesel Research." Biodiesel Update Seminar, Fats and Proteins Research Foundation (FPRF), Chicago, May.

Additional Information: CRIS Accession No.: 9146375 


\section{Project Title:}

\section{Ethyl Ester Process Scale-Up and Biodegradability of Biodiesel}

Background: As biodiesel fuels become commercialized, their fate in the environment is a matter of concem because petroleum oil spills constitute a major source of contamination in the ecosystem. Among these concems, water quality is one of the most important issues for living systems. Even though biodiesel consists of mainly fatty acids, it is not desirable if it accumulates in the waterways. As early as the 1970s, investigators reported that long chain fatty acids, either free or combined, comprise about $80 \%$ of the grease fraction in sewage. Grease has been found to make up $23 \%$ to $52 \%$ of the total organic fraction in sewage. Therefore, it is important to examine the biodegradability of biodiesel fuels and their biodegradation rates in natural waters in case they enter the aquatic environment during the course of their use or disposal.

\section{Objectives:}

- Determine the biodegradability of RME, REE, ethyl soyate, NR, NS, and diesel fuel.

- Coordinate (perhaps by subcontract) toxicology studies for methyl soyate and RME.

- Develop a process for REE comparable to RME.

Status: The project was initiated in 1993 and completed in June 1994.

\section{Accomplishments:}

- Studied improvement in the biodiesel production process for ethyl esters from rapeseed, through a 24-month storage study with REE and RME, with determination of BOD5 and COD for biodiesel and No. 2 diesel. Used both static and flow through tests for determination of toxicity of REE and RME compared to No. 2 diesel using daphnia magna and rainbow trout, and with both aquatic and soil biodegradation studies of various biodiesel fuels and diesel biodiesel blends compared to diesel.

- Some of the significant results were as follows:

- An effective process for ethyl ester production was developed.

- Storage studies found that the cetane, peroxide, acid value, density, and viscosity tended to increase over time and heat of combustion decreased.

- Aquatic biodegradation studies found that all the biodiesel fuels are "readily biodegradable" compounds according to EPA standards and have a relatively high biodegradation rate in the aquatic environment.

- Toxicity studies with both daphnia magna and rainbow trout found that both REE and RME biodiesels were less toxic than diesel fuel in both static and flow-through tests.

- BOD5 values for REE, RME, SME, NR) and NS were significantly higher than for No. 2 diesel fuel. COD values were similar for all fuels tested.

- Results indicate biodiesel fuel substances contain significantly more microbial biodegradable organic matter than does No. 2 diesel.

Participants: University of Idaho, Department of Biological and Agricultural Engineering

Sponsoring Organization(s): US. Department of Agriculture-Cooperative State Research, Education, and Extension Services 
Point of Contact: Dr. Charles Peterson, Department of Agricultural Engineering, University of Idaho, Moscow, ID 83844, phone 208.885.7906, fax 208.885.8923, e-mail peterson@ novell.uidaho.edu.

\section{Papers:}

Zhang, X. (1996). "Biodegradability of Biodiesel in the Aquatic and Soil Environments." Ph.D. dissertation, Dept. of Biol. and Agr. Engr., University of Idaho, Moscow, ID.

Peterson, C.L., D.L. Reece, B.L. Hammond, J.C. Thompson, and S.M. Beck (1997).

"Processing, Characterization and Performance of Eight Fuels from Lipids."

Additional Information: CRIS Accession No.: 9163212 


\section{Project Title:}

Hydrogenated Soy Ethyl Ester (HySEE) Process Refinement

Background: This project was intended to develop information on HySEE process and production methods, and the construction/operation costs of a commercial scale HySEE production process.

Objective: To develop information on HySEE process and production methods, and the construction/operation costs of a commercial scale HySEE production process.

Status: $1994-1995$

Accomplishments: The highlights of this project include evaluating feedstock pretreatment requirements; evaluating hydrogenated soy oil transesterification processing characteristics; evaluating parameters of the primary settler; purifying HySEE and evaluating its characteristics; and producing a preliminary design of a 2,000 gal/d capacity biodiesel plant.

Participants: J.R. Simplot Company, Idaho Transtech and University of Idaho

Sponsoring Organization(s): Pacific Northwest and Alaska Regional Biomass Energy Program

Point of Contact: Dr. David Drown, 308 Buchanan Engineering Lab, Chemical Engineering Dept, University of Idaho, Moscow, ID 83844-1021, phone 208.885.7848, fax 208.885.7467, email ddrown@uidaho.edu.

Papers:

Final Report: Development of a Continuous Process for Making Biodiesel from Waste French Fry Oil and Ethanol, Hydrogenated Soy Ethyl Ester (HySEE) Process Refinement. August 1995. 


\section{Project Title:}

New Processes for Obtaining Higher Value-Added Products from Agricultural Lipids

Background: This project is a follow-on to an earlier ARS project titled "Conversion of Natural Glycerides to Higher-Value Products." New processes that use biocatalysts to harvest industrially important fatty acids will be developed. Biocatalysts will be exploited to restructure natural triglycerides to alter physical properties and thereby enhance market value. This project will aim to:

- Optimize bioprocessing technologies to improve the economics of enzymatic biodiesel production from fats, oils and greases.

- Explore the potential of biocatalysis for the production of fuel oxygenates and/or biodegradable lubricants.

- Upgrade edible fats and oils by enzymatic modification in supercritical fluids. Produce biopolymeric materials from fat and oil substrates using bacteria that utilize glycerides as substrates.

- Use biochemical and/or biomimetic chemical catalysis to produce oxygenated fat and oil products enriched in commercially valuable materials such as plasticizers, emulsifiers, and surfactants.

- Develop new enzyme immobilization processes.

- Develop catalytic processes for altering the linear structure of fatty acids into branched chain isomers.

Objectives:

- New processing technologies based upon biocatalysis and/or biomimetic reagents will be developed for converting animal fats and vegetable oils into value-added products.

- Targeted areas will include harvesting of industrially important fatty acids from fats and oils; the restructuring of natural glycerides; production of biodiesel and biobased fuel additives and lubricants; industrial biopolymers; and oxygenated and branched chain materials from agrochemical glycerides.

Status: $1997-2001$

Accomplishments: In progress.

Participants: U.S. Department of Agriculture-Eastem Regional Research Center

Sponsoring Organization(s): U.S. Department of Agriculture-Agricultural Research Service Eastem Regional Research Center

Point of Contact: Thomas A. Foglia, Eastem Regional Research Center, Wyndmoor, PA 19038, phone 215.233.6480, fax 215.233.6795, e-mail tfoglia@arservc.gov.

Papers: None available at this time.

Additional Information: CRIS Accession No.: 9400303 
Project Title:

Process Scale-Up for Catalytic Oxidation of Unsaturated Fatty Acids and Glycerolysis

Background: Not available

Objectives: Explore the preparation technique and characterize the properties and performance of ethers of glycerol as additives in diesel fuel.

Status: Not available

Accomplishments: Not available

Participants: Chemical Engineering, University of Nebraska, USDA-CSREES

Sponsoring Organization(s): U.S. Department of Agriculture-Cooperative State Research, Education, and Extension Services

Point of Contact: Dr. Hossein Noureddini, Dept. of Chemical Engineering, University of Nebraska-Lincoln, Lincoln, NE 68588-0126, phone 402.472.2751.

Papers: None available at this time. 
Project Title:

Process Scale-up for Transesterification an Glycerolysis of Soybean Oil Utilizing a High Shear Liquid-Liquid Contact Device

Background: Many industrial processes, which utilize triglycerides or their fatty acid derivative, rely on mutual solubility and homogencity of liquid phases involved. Consequently, elevated temperatures and pressures must be used to increase the solubility of liquid phases. The goal of this research is to test a high shear liquid-liquid contact device in the transesterfication and glycerolysis processes. This arrangement is expected to achieve practical conversions at relatively more moderate conditions for temperature and pressure.

Objectives: The goal of this research project is to develop a multi-purpose pilot plant facilities using a specific high shear liquid-liquid contact device for process evaluation, scale-up, and small-scale production of esters of fatty acids (biodiesel) by transesterification process and mono- and diglycerides by glycerolysis process. The specific objectives are to:

- Construct a continuous multi-purpose pilot facilities.

- Investigate the effect of a high shear liquid contact device for achieving the solubility and homogeneity requirements in transesterification and glycerolysis processes.

- Develop and scale up a process of an economically feasible technology based on the proposed reactor for transesterification and glycerolysis processes.

- Investigate other potential derivatives of glycerin suitable for production from crude glycerin.

Status: This project has been ongoing since September 1, 1993 and is scheduled to be completed by August 31, 1997.

Accomplishments: All the proposed objectives have been completed. Results are available in reports, papers, and thesis work.

Participants: Chemical Engineering, University of Nebraska, U.S. Department of AgricultureCooperative State Research, Education, and Extension Services, Nebraska Soybean Board

Sponsoring Organization(s): - U.S. Department of Agriculture-Cooperative State Research, Education, and Extension Services, Nebraska Soybean Board, University of Nebraska-Lincoln.

Point of Contact: Dr. Hossein Noureddini, Department of Chemical Engineering, University of Nebraska-Lincoln, Lincoln, NE 68588-0126, phone 402.472.2751.

Papers:

Noureddini, H. and V. Medikondur (1997). "Glycerolysis of Fats and Methyl Esters." J. Am. Oil Chem. Soc., 74(4), 419.

Noureddini, H, D.W. Harky, and V. Medikondur (1997). "A Continuous Process for the Conversion of Vegetable Oils into Biodiesel," submitted to Biosource Technology.

Noureddini, H. and D. Zhu (1996). Mixing Effects on the Transesterification Kinetics of Soybean Oil," J. Am. Oil Chem. Soc., in press.

Muniyappa, P.R., S.C. Brammer, and H. Noureddini (1996). "Improved Conversion of Plant Oils and Animal Fats into Biodiesel and Co-product." Biosource Technology, 56, 19. 
Muniyappa, P.R. (1995). "Production of Biodiesel and Utilization of By-Product," M.S. Thesis, University of Nebraska-Lincoln.

Medikondur, V. (1996) "Continuous Transesterification of Vegetable Oils and Utilization of CoProduct." M.S. Thesis, University of Nebraska-Lincoln. 


\section{Fuel Characteristics}

\section{A. Properties}

Also see the following projects:

Altemative Fuels and Lubricants from Rapeseed

Developing Yellow Mustard (Sinapis Alba L.) Cultivators Suitable for Biodiesel Production in the United States

Multifeedstock Biodiesel Project

Third Workshop: Commercialization of Biodiesel: Producing a Quality Fuel 


\section{Project Title:}

Additive Compatibility

Background: Petrodiesel can contain a variety of performance additives. The engine manufacturers are interested in the negative reaction of biodiesel with additives. Specifically, they are interested in knowing whether the additives are as effective with biodiesel as with petrodiesel. The purpose of this research is to quantify any negative reactions and document the effects of a representative number of additives or additive packages with biodiesel and biodiesel blends.

\section{Objectives:}

- Determine whether commercially available diesel fuel additives are compatible with and maintain their efficacy with biodiesel fuels.

- Evaluate the products characteristics of the cetane number (combustion characteristic of diesel fuels), conductivity, corrosiveness, and stability.

- Use a" trial and error" approach and all the information regarding the additives will be captured.

Status: Completed February 11, 1997

\section{Accomplishments:}

- The results of the project determined the additives developed for petrodiesel were generally effective in biodiesel, except the corrosion control additive.

- Conventional petroleum-based stability additives were ineffective with biodiesel but a common soybean oil stabilizer in combination with a petroleum-based stabilizer produced promising results.

- Biodiesel imparts electrical conductivity to petrodiesel blends, reducing the potential of static electricity buildup and potential static electricity discharge when pumping. Conductivity additives appear unnecessary for biodiesel blends.

- Further research into exact treat rates with various additives is needed.

Participants: National Biodiesel Board and System Lab Services, a division of Williams Pipe Line Company

Sponsoring Organization: National Biodiesel Board

Point of Contact: Ms. Bev Thessen, National Biodiesel Board, P.O. Box 104898, Jefferson City, MO, 65110-4898, phone 573.635.3893, fax 573.635.7913, e-mail biodiesel@ sockets.net.

\section{Paper:}

Lawrence, R. (1997). Determination of Additive Compatibility and Efficacy. Final Report. NBB 209. Jefferson City, MO, National Biodiesel Board. 


\section{Project Title:}

ASTM Standards Development and Industry Acceptance

Background: Full-scale biodiesel commercialization and sales are limited without an industry - engine manufacturer, producer and user-accepted standard. The biodiesel industry is currently conducting research on analytical testing methods and the specifications needed for each analytical test. This project allocates the time and resources necessary to facilitate the development of the standard.

Objectives:

- Support information necessary for approval of a biodiesel standard through the ASTM Biodiesel Task Force.

- Facilitate feedback on draft ASTM specifications from OEMs, producers, distributors, users, and researchers, and investigate the proper analytical methods for ASTM specification.

- Help determine the actions needed to gain agreement on the specification within the ASTM process and assist in executing the actions developed by ASTM to ensure specifications are based on sound scientific methods and on the requirements of customers, engine manufacturers, and producers.

- Provide recommendations to the industry for further research needed based on feedback from engine manufacturers, producers, and users.

Status: September 1, 1993-present

\section{Accomplishments:}

- Information has been shared at several industry conferences and has been used to determine industry research priorities.

- Information has been shared at the semiannual ASTM Biodiesel Task Force meeting.

- Consensus has been achieved on the testing needs and values for the standard.

- The gas chromatography method was selected to measure free and total glycerin.

- ASTM voted to move forward with a provisional ASTM biodiesel standard (1997) while data on the GC, precision and bias for other analytical methods, and further field information is generated for the full ASTM standard. The full ASTM standard must be issued within 2 years of acceptance of the provisional standard.

- A provisional ASTM has been sent to ballot. Comments were incorporated; and it is being sent out for re-ballot (late 1997).

Participants: American Society for Testing and Materials, analytical laboratories, biodiesel suppliers, engine manufacturers, and MARC-IV Consulting, Inc.

Sponsoring Organization(s): National Biodiesel Board and United Soybean Board

Point of Contact Steve Howell, MARC-IV Consulting, Inc, 16200 Northridge Road, Kearney, $\mathrm{MO}, 64060$, phone 816.635.5772, fax 816.635.4836, e-mail showell @marciv.com.

Paper:

Draft ASTM Standard 


\section{Project Title:}

Beef Tallow as a Biodiesel Fuel

Background: Vegetable oils and animal fats can be used as fuel in direct injection diesel engines, but there are some limitation on their use. From the point of view of fuel properties, both oil and fat are fairly close to that of diesel fuel, but from the point of view of physical properties they are not close to diesel fuel. One of the most important physical properties of vegetable oils and fats is viscosity; oils are more viscous than diesel fuel. To use these highly viscous oils and fats as fuels in a compression ignition engine, one must modify their physical properties.

Objectives: This project evaluated beef tallow performance as a potential replacement to diesel fuel.

\section{Status: Completed}

\section{Accomplishments:}

- The presence of a high amount of saturated fatty acid causes tallow to be solid at room temperature.

- Viscosity, specific gravity, distillation range, melting point, cloud point and pour point were higher than those for No. 2 diesel fuel.

- Fuel properties including cetane index and flash point were better than diesel fuel.

- The engine performance showed that there was $1.1 \%$ power reduction for each $10 \%$ replacement of diesel fuel with methyl tallowate and ethanol.

Participants: University of Nebraska-Lincoln

Sponsoring Organization(s): University of Nebraska-Lincoln

Point of Contact: Milford Hanna, Director, Industrial Agricultural Products Center, $211 \mathrm{LW}$ Chase Hall, University of Nebraska-Lincoln, Lincoln, NE 68583-0730, phone 402.472.1624.

Paper(s):

Ali, Y. and M.A. Hanna (1996). "Beef Tallow as a Biodiesel Fuel." Proceedings of the Third Liquid Fuels Conference, September 15-17, Nashville, TN. Liquid Fuels and Industrial Products from Renewable Resources; pp. 59-72. 


\section{Proiect Title:}

Biodiesel Cetane Number Engine Testing Comparison to Calculate Cetane Index Number

Background: Unlike gasoline, diesel fuel is measured by its cetane value, not its octane value. Before marketing biodiesel to the retail distributors and fleet managers, it was imperative to understand cetane rating of biodiesel compared to diesel fuels.

\section{Objectives:}

- Determine whether the calculated CN index from D 976 and D4737 correlate for biodiesel based on density, gravity, and distillation.

\section{-Status:-Complete ..}

\section{Accomplishments:}

- Biodiesels were shown to have a high $\mathrm{CN}$ and can be considered a premium diesel fuel.

- Significant decline in the estimated calculated cetane index numbers versus cetane engine numbers.

- The blended CNs tended to increase as the percentage of ester was increased. This indicates that biodiesels could be good blending stock to enhance cetane while lowering sulfur and aromatics of conventional fuels.

Participants: Midwest Biofuels, Inc., Williams Pipeline Company

Sponsoring Organization(s): Midwest Biofuels, Inc.

Point of Contact: Midwest Biofuels, Inc, 30 N. $1^{\text {st }}$ Street, Kansas City, KS 66118, phone 913.371.3835.

\section{Paper:}

Midwest Biofuels, Inc. Biodiesel Cetane Number Engine Testing Comparison to Calculated Cetane Index Number. Overland Park, Kansas: Midwest Biofuels, Inc. 


\section{Project Title:}

Biodiesel Fuel Certification and Quality Assurance

Background: For many years, biodiesel research and demonstrations progressed without any concern over fuel quality. The industry held the belief that industrial grade methyl esters were sufficient for fuel use. Over the years, it became evident that fuel quality was an extremely important issue, and NBB has moved to develop proposed ASTM standards for biodiesel. This project is the second step in institutionalizing fuel quality standards throughout the industry.

Objectives: NBB has decided to move forward with testing industry fuel samples against the proposed ASTM biodiesel standards, working with the producers to develop adequate fuel quality assurance programs within each company, and to "certify" producers to meet fuel specifications on a regular basis. NREL has decided to move forward with a report that discusses the importance of fuel quality and fuel specifications from the consumer point of view, including contractual mechanisms for purchasing biodiesel on spec. This report will also include protocols for consumers and other entities in the fuel handling chain necessary for maintaining fuel quality all along the fuel distribution and storage process once biodiesel leaves the producer's dock.

Status: Project will begin in FY 1997 and conclude by June 1998.

Accomplishments: Ongoing

Participants: National Renewable Energy Laboratory and National Biodiesel Board

Sponsoring Organization: U.S. Department of Energy Office of Fuels Development and National Biodiesel Board

Point of Contact: Dr. K. Shaine Tyson, National Renewable Energy Laboratory, 1617 Cole Blvd., Golden, CO 80401, phone 303.275.4616, fax 303.275.4675, e-mail tysonk@tcplink.nrel.gov.

Papers:

Biodiesel Fuel Quality Standards and Recommended Operating Protocols for Maintaining Fuel Quality (forthcoming). 
Project Title:

Biodiesel Fuels--Vegetable Oil/Alcohol Blends

Background: There is a need to develop modified vegetable oils as altemative fuels for combustion in compression ignition (diesel) engines. Blending with simple alcohol to form microemulsion or co-solvent type hybrid fuels and conversion to biodiesel are promising technologies for improving viscosity of vegetable oils. This project explores development of hybrid formulations and biodiesel with improved viscosity, surface tension, and lowtemperature properties as well as improved combustion and emissions characteristics.

Status: January 1992-January 1997

\section{Objectives:}

- Modify and improve the combustion of vegetable oils, emphasizing soybean oil, as diesel fuel by obtaining and applying new knowledge of precombustion chemistry.

- Develop technologies for producing improved biodiesel through unique combinations of vegetable oil, simple alcohol, and surfactant packages.

- Evaluate performance characteristics, including emissions, of the most promising fuel formulations and additives determined from ongoing research activities.

Status: FY 1992-1997

Accomplishments:

- Long- and medium-chain length alcohol surfactant packages were developed for solubilized soybean oil with methanol and ethanol.

- These vegetable oilvalcohol blends showed significant reduction in viscosity with little or no compromising of other fuel properties, such as $\mathrm{CN}$.

- Low-temperature flow property studies of biodiesel indicated that biodiesel (methyl soyate) poses more significant startup and operability problems during cooler seasons in moderate climates.

- Testing of distillate/biodiesel blends showed that no more than $20 \%$ by volume biodiesel may be blended before problems such as blocked fuel lines and plugged filters will be encountered.

- Shown that improving cold flow of biodiesel and blend s depends directly on reducing cloud point. Cold flow improver additives were effective in reducing pour point of blends; however, cloud points were not affected.

- Winterization of methyl soyate showed promise by reducing cloud points to levels approaching those of distillate fuels.

- Thermal analysis techniques were developed that could accurately predict cloud points of diesel fuels.

- Cetane improvers were developed that showed novel effects on cetane numbers of fatty acids and esters. Results showed how CNs and their improvements in fatty compounds depend upon their chemical structure. Thus, cetane-improving additives may be tailored to specific chemical structures present in vegetable oils and fuels derived therefrom.

Participants: Southwest Research Institute; University of Illinois; and U.S. Department of Agriculture-Agricultural Research Service, National Center for Agricultural Utilization Research 
Sponsoring Organization(s): U.S. Department of Agriculture-Agricultural Research Service, National Center for Agricultural Utilization Research

Point of Contact: Robert Dunn, USDA-ARS, National Center for Agricultural Utilization Research, 1815 N. University Street, Peoria, IL 61604, phone 309.681.6413, fax 309.681.6686, e-mail dunnro@mail.ncaur.usda.gov.

\section{Papers:}

Knothe, G., R. O. Dunn, and M.O. Bagby (1997). "Biodiesel: The Use of Vegetable Oils and Their Derivative as Altemative Diesel Fuels." In ACS Symp. Ser. No. 666: Fuels and Chemicals from Biomass. B.C. Saha; J. Woodward, eds. American Chemical Society, Washington, DC. pp. 172-208.

Dunn, R.O., M.W. Shockley, and M.O. Bagby (1996). "Improving the Low-Temperature Properties of Altemative Diesel Fuels: Vegetable Oil-Derived Methyl Esters." J. American Chemical Society, 73:1719.

Dunn, R.O. and M.O. Bagby (1996). "Low-Temperature Filterability Properties of Alternative Diesel Fuels from Vegetable Oils." Proceedings of the Third Liquid Fuel Conference, September 15-17, 1996. St. Joseph, Ml: The American Society of Agricultural Engineers; pp. 95-103.

Knothe, G. and M.O. Bagby (1996). "Assignment of 13C Nuclear Magnetic Resonance Signals in Fatty Compounds with Allylic Hydroxy Groups." J. Am. Oil Chem. Soc. 3:661.

Knothe, G., M.O. Bagby, and T.W. Ryan, III (1996). "The Influence of Various Oxygenated Compounds on the Cetane Numbers of Fatty Acids and Esters." Proceedings of the Third Liquid Fuels Conference, September 15-17, 1996, Nashville, TN. Liquid Fuels and Industrial Products from Renewable Resources, pp. 54-58.

Knothe, G., R.O. Dunn, and M.O. Bagby (1996). "Technical Aspects of Biodiesel Standards." INFORM 7:827.

Dunn, R.O. and M.O. Bagby (1995). "Low-Temperature Properties of Triglyceride-Based Diesel Fuels: Transesterified Methyl Esters and Petroleum Middle Distillate/Ester Blends." J. Am. Oil Chem. Soc. 72:43.

Dunn, R.O. and M.O. Bagby (1995). "Aggregation Of Unsaturated Long-Chain Fatty Alcohols In Nonaqueous Systems." J. Am. Oil Chem. Soc. 72:123.

Knothe, G., M.O. Bagby, and D. Weisleder (1995). "Fatty Alcohols through Hydroxylation of Symmetrical Alkenes with Selenium Dioxide/Tert-Butylhydroperoxide." J. Am. Oil Chem. Soc. 72:1021.

Knothe, G., R.O. Dunn, and M.O. Bagby (1994). "Surface Tension Studies on Novel Allylic Mono- and Dihydroxy Fatty Compounds. A Method to Diastereomers." J. Am. Oil Chem. Soc. Accepted May 25, 1994.

Dunn, R.O. and M.O. Bagby (1994). "Solubilization of Methanol and Triglycerides:

Unsaturated Long-Chain Fatty Alcohol/Medium-Chain Alkanol Mixed Amphiphile Systems." J. Am. Oil Chem. Soc. 71:101. 
Knothe, G, M.O. Bagby, D. Weisleder, and R.E. Peterson (1994). "Allylic Mono- and Dihydroxylation of Isolated Double Bonds with Selenium Dioxide-tert-butyl ... Enones." J. Chem. Soc., Perkin Trans. 2:1661.

Knothe, G. and M.O. Bagby (1994). "13C-NMR Spectroscopy of Unsaturated Long-Chain Compounds: An Evaluation ... Carbon Signals as Rational Functions." J. Chem. Soc., Perkin Trans 2: Accepted November 9, 1994.

Dunn, R.O. A.W. Schwab, and M.O. Bagby (1993). "Solubilization and Related Phenomena in Nonaqueous Triolein/Unsaturated Long Chain Fatty Alcohol/Methanol Solutions." J. Dispersion Sci. Technol. 14:1.

Additional Information: ARS Project No. 3620-41000-050-00D; CRIS Accession No.: 9146551. 


\section{Project Title:}

Biodiesel Pour Point and Cold Flow Study

Background: The cold flow properties of diesel fuel are important parameters in maintaining satisfactory fuel flow and performance in diesel engines. Conventional diesel fuel experiences cold flow jelling in the colder climates of the United States each year. The authors desired to determine the impact of biodiesel and biodiesel blends on the cold flow performance of petrodiesel and to evaluate the available options for improvement of cold flow performance when using biodiesel.

Objectives: To provide for research and documentation of the pour point and cloud point of methyl soyate and the cold flow characteristics and other biodiesels.

Status: September 1993

\section{Accomplishments:}

- The cold flow properties of biodiesel need improvement in order to be used in cold weather.

- Blending biodiesel with No. 1 or No. 2 diesel is an effective means to improve cold flow properties.

- Conventional cold flow additives appear to be effective with diesel and with blends, but showed little, if any, effect on the neat biodiesel.

- The effectiveness of any cold flow improver changes with the diesel fuel being used.

- Conventional diesel fuel cold flow properties can change drastically and therefore, the pour point, cloud point, and cold filter plugging point of biodiesel blends should not be discussed in absolute terms, but in terms of degrees of change from conventional diesel.

Participant: Midwest Biofuels

Sponsoring Organization(s): National Biodiesel Board

Point of Contact: Ms. Bev Thessen, National Biodiesel Board, P.O. Box 104898, Jefferson City, MO, 65110-4898, phone 573.635.3893, fax 573.635.7913, e-mail biodiesel@sockets.net.

\section{Paper:}

Midwest Biofuels (1993). Biodiesel Pour Point and Cold Flow Study. Jefferson City, MO: National Biodiesel Board. 
Project Title:

Biodiesel Technical Fuel Quality Laboratory Analysis

Background: These results will provide additional information needed to confirm the statistical validity of projects completed during FY 1995.

\section{Objectives:}

- To provide complete analysis and characterization for biodiesel being used in current biodiesel field trials or research.

- To complete sufficient replication of sample results to obtain statistically valid analysis and compare that analysis against specifications.

- To use these data to help NBB and others gather performance-based information, which can be used to update biodiesel specifications.

Status: October 1, 1994-September 30, 1995

Accomplishments:

- Identified the need for a standardized method for total and free glycerin and for a detailed ASTM standard.

- All laboratories could provide partial testing, but no one laboratory could be identified as being able to complete all tasks necessary to ensure fuel quality and statistical control.

- There was significant variation between the results for several parameters from different laboratories on the sample.

- Additional biodiesel laboratories are needed--this project was unable to identify multiple laboratory testing facilities that could complete all NBB fuel quality testing.

Participants: Brabmij Inc.

Sponsoring Organization(s): National Biodiesel Board

Point of Contact: Ms. Bev Thessen, National Biodiesel Board, P.O. Box 104898, Jefferson City, MO, 65110-4898, phone 573.635.3893, fax 573.635.7913, e-mail biodiesel @ sockets.net. Mr. Steve Howell, MARC-IV Consulting, Inc, 16200 Northridge Road, Kearney, MO, 64060, phone 816.635.5772, fax 816.635.4836, e-mail showell@marciv.com.

Paper:

Gardner, J.M. (1996). Biodiesel Fuels Quality Evaluation Using Commercial Materials/ Chemical Testing Laboratories. NBB 96220-1. Jefferson City, MO: National Biodiesel Board. Work performed by Brabmij, Inc., Pittsburgh, MO. 


\section{Project Title:}

Blending Rules for Formulating Biodiesel Fuel

Background: Biodiesel is gaining acceptance in a number of markets as an enhanced performance fuel for compression ignition engines. The most significant hurdle for broader commercialization of biodiesel is its cost. Because the most important cost factor in biodiesel production is the raw material, there has been an increasing effort in the use of lower cost raw materials such as tallow, recovered cooking oils, and yellow grease for the production of the fuel quality esters.

\section{Objectives:}

- Use pure component data for methyl palmitate, methyl stearate, methyl oleate, and methyl linoleate to develop and test blending equations for predicting fuel density, viscosity, $\mathrm{CN}$, cloud point, and heating value.

- Compare the results of the blending relationship with literature values for biodiesel from a number of triglyceride sources.

Status: 1996

Accomplishments: This project generated formulas for estimating density, viscosity, CN, cloud point, and heating value of biodiesel blends.

Participants: University of Nebraska, U.S. Department of Agriculture-Cooperative State Research, Education, and Extension Services

Sponsoring Organization(s): U.S. Department of Agriculture-Cooperative State Research, Education, and Extension Services

Point of Contact: L. Davis Clements, Biological Systems Engineering, University of Nebraska-Lincoln, Lincoln, NE 68583-0726; phone 402.472.0177, fax 402.472.6338

Paper(s):

Clements, L.D. (1996) . "Blending Rules for Formulating Biodiesel Fluid." Proceedings of the Third Liquid Fuels Conference, September 15-17, 1996, Nashville, TN. Liquid Fuels and Industrial Products from Renewable Resources; pp. 44-53. 


\section{Project Title:}

Cetane Number Testing of Biodiesel

Background: The $\mathrm{CN}$ is one of the most commonly cited indicators of diesel fuel quality. It measures the readiness of the fuel to autoignite when injected into the engine. It is generally dependent on the composition of the fuel and can impact the engine's startability, noise level, and exhaust emissions. The $\mathrm{CN}$ of biodiesel is generally observed to be quite high. Date presented in this work will show values varying between 45 and 67.

\section{Objectives:}

- Evaluate the possible reasons for the wide range in reported values of the $\mathrm{CN}$ of biodiesel.

- Suggest ways of reporting the fuel properties of biodiesel that correlate to CN.

Status: Completed

\section{Accomplishments:}

- The CN of biodiesel depends on the distribution of fatty acids in the original oil or fat in which it is produced. The longer the fatty acid carbon chains and the more saturated the molecules, the higher the $\mathrm{CN}$.

- The unsaponifiable matter in biodiesel does not appear to have an impact on the CN.

- Fuel that has been distilled, oxidizes much more quickly than undistilled fuel. Although the distillation process does not affect the $\mathrm{CN}$, the oxidation result in a $\mathrm{CN}$ increase. When the fuel was oxidized to peroxide value of 82 , the $C N$ increased between 7 and 8 points. Further increases in the peroxide value did not increase the $\mathrm{CN}$.

Participants: lowa State University, lowa Energy Center, lowa Soybean Promotion Board

Sponsoring Organization(s): lowa Energy Center, lowa Soybean Promotion Board

Point of Contact: Jon Van Gerpen, Mechanical Engineering Department, lowa State University, 2025 Black Engineering Bldg., Ames, IA 50011-2161, phone 515.294.5563, fax 515.294.3261, e-mail jvg@iastate.edu.

Paper(s):

Van Gerpen, J. (1996). "Cetane Number Testing of Biodiesel." Proceedings of the Third Liquid Fuels Conference, September 15-17, 1996, Nashville, TN. Liquid Fuels and Industrial Products from Renewable Resources; pp.197-206. 


\section{Project Title:}

Cetane Numbers of Fatty Compounds

Background: The $\mathrm{CN}$ is one of the prime indicators of diesel fuel quality. It is related to the ignition delay time a material experiences upon injection into the combustion chamber. Generally the shorter the ignition delay-time, the higher the $\mathrm{CN}$ and vice versa. $\mathrm{CN}$ is usually determined by the method described in ASTM D 613, although an altemative using a CVCA has been reported and developed into an Ignition Quality Tester for laboratories and refineries. Vegetable oils, animal fats, and their derivatives ("biodiesel") are prominent candidates as alternative diesel fuels. However, for fatty compounds an alternative to the cetane scale, the "Lipid Combustion Quality Number," which would account for CNs in excess of 100, was suggested.

Objective: To determine the $\mathrm{CNs}$ of various fatty acids and esters to potentially improve these properties.

Status: Completed 1997

Accomplishments:

- There is a possibility of tailoring the cetane improver to the predominant fatty compounds present in the biodiesel.

- The factors influencing the choice of cetane improver are the nature of the fatty $\mathrm{HC}$ chain and the nature of the ester.

Participants: Southwest Research Institute, U.S. Department of Agriculture

Sponsoring Organization(s): US. Department of Agriculture

Point of Contact: Thomas W. Ryan III, Southwest Research Institute, 6220 Culebra Road, San Antonio, TX 78238-5100, phone 210.684.5111, fax 210.522.3496.

Paper(s):

Knothe, G., M.O. Bagby, and T.W. Ryan (1997). "Cetane Numbers of Fatty Compounds: Influence of Compound Structure and Various Potential Cetane Improvers." State of Alternative Fuel Technologies (SP-1274); May 5-8, 1997, Dearborn, MI. SAE \# 971681. Warrendale, PA: Society of Automotive Engineers, pp. 127-132. 


\section{Project Title:}

Development of Premium Diesel Fuel Standards

Background: This project provides technical support to NREL by representing biodiesel benefits during the developing an agenda for premium diesel specifications and biodiesel's potential roles in this market.

\section{Objectives:}

- The National Conference on Weights and Measures is developing recommended specifications for premium diesel fuels. Although so-called premium diesel fuels abound in the marketplace, there are no regulations or standards for what comprises premium diesel fuel. Engine manufacturers have been pressing for such a specification because of the potential to improve engine emissions and performance offered by an appropriately defined premium diesel fuel. The consultant will attend meetings of this conference to represent issues and concems related to biodiesel.

- Develop a "How To" Guide for Biodiesel Supplier Compliance with Federal Regulations: As new biodiesel producers appear in the U.S. fuel market, they face a sometimes bewildering array of regulation goveming the production, sale, and use of biodiesel.

Status: The ASTMNCWM Joint Premium Diesel Task Force has finished deliberations and has passed on recommendations for premium diesel specifications and testing methods to the main body of the relevant organizations. Lubricity, which is biodiesel's primary benefit in premium diesel blends, was not included in the task force's list of premium diesel's measurable characteristics, but was listed as a possible sixth specification if the industry can develop improved lubricity test methods. Current lubricity test methods are not accurate enough to distinguish between "average" diesel and premium diesel lubricity levels. It is hoped that the ASTM lubricity task force will take up this issue in future meetings, as this is an industry wide issue. NREL will proceed with developing the necessary data to determine the lubricity benefits of biodiesel in low-level blends in FY 1998 to help producers penetrate this high-value market.

Accomplishments: Various letter reports describing progress in the ASTMNCWM Premium Diesel Task Force meetings were provided during the course of the contract period. A rough draft of the "How To" guide has been submitted.

Participants: National Renewable Energy Laboratory and Fats and Proteins Research Foundation, Inc.

Sponsoring Organization(s): U.S. Department of Energy Office of Fuels Development and Fats and Proteins Research Foundation, Inc.

Point of Contact: Dr. K. Shaine Tyson, National Renewable Energy Laboratory, 1617 Cole Blvd., Golden, CO, 80401-3393, phone 303.275.4616, fax 303.275.4675, e-mail tysonk@tcplink.nrel.gov.

Papers:

"How To" Regulatory Compliance Guide (draft). 


\section{Project Title:}

Diesel Fuel, Extenders, and Additives from Vegetable Oils

Background: This project continues the development of modified vegetable oils as an alternative fuel for combustion in compression ignition (diesel) engines. Although biodiesel reduced most emissions, it does not greatly reduce harmful $\mathrm{NO}_{x}$ emissions. There is a need to develop new knowledge of precombustion chemistry to improve combustion and reduce emissions. There is a need to develop information to improve low-temperature flow properties of biodiesel without compromising fuel properties such as oxidative stability or cetane number. Finally, there is a need to develop quick and inexpensive methods for testing fuel quality.

\section{Objectives:}

- Improve combustion characteristics and fuel properties of vegetable oils and their derivatives as fuels, extenders, and additives for combustion in diesel engines.

- Use fatty derivatives to enhance performance and reduce harmful exhaust emissions.

- Modify vegetable oils and their derivatives with improved viscosity, surface tension, combustion, and low-temperature flow properties.

- Develop combustion-improving additives that also reduce harmful exhaust emissions, in particular $\mathrm{NO}_{\mathrm{x}}$.

- Develop methods such as winterization, cold-solvent extraction, cold-flow improvers, and solubilization with surfactants for improving low-temperature flow properties of biodiesel.

- Develop spectroscopic methods for quick, easy, and low-cost testing of biodiesel fuel quality.

- Evaluate performance and emissions characteristics of promising fuel formulations developed from ongoing research activities.

Status: The project was initiated in January 1997 and will be completed by January 2002

\section{Accomplishments:}

- In progress

Participants: U.S. Department of Agriculture-Agricultural Research Service, National Center for Agricultural Utilization Research, Southwest Research Institute, University of Illinois

Sponsoring Organization(s): U.S. Department of Agriculture-Agricultural Research Service, National Center for Agricultural Utilization Research

Point of Contact: Robert Dunn, USDA-ARS, National Center for Agricultural Utilization Research, 1815 N. University Street, Peoria, IL 61604, phone 309.681.6413, fax 309.681.6686, e-mail dunnro@mail.ncaur.usda.gov.

Paper(s):

Dunn, R.O. (1997). "Improving the Low-Temperature Properties of Biodiesel." The Liquid Biofuels Newsletter 9. BLT, Wieselburg, Austria, pp. 10-12.

Dunn, R.O., M.W. Schockley, and M.O. Bagby (1997). "Winterized Methyl Esters from Soybean Oil: An Alternative Diesel Fuel with Improved Low-Temperature Properties." SAE Spec. Publ. Sp-1274: State of Alternative Fuel Technologies 1997. SAE Technical Paper Services No. 97 (1682). Society of Automotive Engineers, Warrendale, PA, pp. 133-142. 
Dunn, R.O., Knothe, G; Bagby, M.O. (1997). "Recent Advances in the Development of Altemative Diesel Fuel from Vegetable Oils and Animal Fats." Recent Res. Devel. Oil Chem. 1:31.

Knothe, G. (1997). "Effects of Structure of Fatty Compounds on Their Cetane Numbers." The Liquid Biofuels Newsletter 9. BLT, Wieselburg, Austria, pp. 9-10.

Knothe, G., Bagby, M.O.; Ryan III, T.W. (1997). "Cetane Numbers of Fatty Compounds: Influence of Compound Structure and of Various Potential Cetane Improvers." In SAE Special Publications. SP-1274: State of Altemative Fuel Technologies-1997 (SAE Technical Paper Series No. 971781). Society of Automotive Engineers, Warrendale, PA, pp. 127-132.

Additional Information: ARS Project No. 3620-41000-075-00D. 


\section{Project Title:}

Development of Biodiesel Slurry Fuels

Background: Similar to ethanol and biodiesel, biodiesel slurries are fuels that could be used as alternatives to diesel to power diesel engines. For short-term applications these fuels could be produced from com or sorghum, and in 10 to 15 years could be produced from agricultural by-products such as corn stalks or wheat straw. These fuels would provide new markets for agricultural products and ultimately lead to increased revenues throughout the agricultural base.

\section{Objectives:}

- Summarize the physical property information and preliminary cost estimates for slurry fuels based on com, sorghum, and cellulose feedstocks.

- Describe current research on constant volume combustion studies and engine demonstrations.

Status: Completed

Accomplishments:

- Biomass has advantages over coal because of reduced ash content and widespread availability.

- The cost of biodiesel slurry fuels to farmers would be different than those costs to other consumers because farmers would benefit from price increases resulting from increased demand for farm products such as corn and sorghum.

- Com and sorghum would have the greatest immediate utility in slurry fuels due to well known milling methods to attain particle sizes smaller than 100 microns.

Participants: University of Kansas, DuPont Educational Grants, Kansas Com Commission

Sponsoring Organization(s): University of Kansas, DuPont Educational Grants, Conoco Undergraduate Research Programs, Kansas Com Commission

Point of Contact: Galen Suppes, University of Kansas, Department of Chemical and Petroleum Engineering, Lawrence, KS 66045-2223, phone 913.864.3864

\section{Paper(s):}

Suppes, G.J.; Ng, C.; Srinivasan, B. (1994). "Development of Biodiesel Slurry Fuels." Proceedings of the 6th National Bioenergy Conference, vol. I, Bioenergy '94, Reno-Sparks, NV. Westem Regional Biomass Energy Program, pp 81-88. 


\section{Project Title:}

Improving the Low-Temperature Properties of Altemative Diesel Fuels: Vegetable Oil-Derived Methyl Esters

Background: Methyl esters from soybean oil have many fuel properties that make them attractive altemative diesel fuels. Recent research has shown that operability problems may develop when fuels systems powered by methyl esters are exposed to ambient temperatures near freezing $\left(0^{\circ} \mathrm{C}\right)$.

Objective: To explore near-term approaches for improving the cold flow of methyl esters and distillate/methyl ester blends.

Status: August 1996

Accomplishments:

- The work supports earlier conclusions regarding improving the low-temperature operability of methyl esters--effective approaches should focus on reducing cloud point.

Participants: U.S. Department of Agriculture-Agricultural Research Service, National Center for Agricultural Utilization Research

Sponsoring Organization(s): U.S. Department of Agriculture-Agricultural Research Service

Point of Contact: Robert Dunn, USDA-ARS, National Center for Agricultural Utilization Research, 1815 N. University Street, Peoria, IL 61604, phone 309.681.6413, fax 309.681.6686, e-mail dunnro@mail.ncaur.usda.gov

Paper:

Dunn, R.O.;M.W. Shockley; Bagby, M.O. (1996). "Improving the Low-Temperature Properties . of Altemative Diesel Fuels: Vegetable Oil-Derived Methyl Esters" (unpublished report). 


\section{Project Title:}

Ignition and Combustion Characteristics of Biofuels

Background: Most exhaust emissions are reduced when using biodiesel as an alternative in a $\mathrm{Cl}$ engine in comparison to conventional diesel fuel. An exception is $\mathrm{NO}_{x}$, whose emissions are at approximately the same level with biodiesel and petrodiesel. $\mathrm{NO}_{x}$ emissions are regulated tailpipe emissions and are precursors of ozone, a major component in urban smog. Ozone is regulated in ambient air. In order to meet increasingly stringent environmental regulations, it is necessary to develop techniques for reducing $\mathrm{NO}_{\mathrm{x}}$ emissions from combustion of biodiesel. Additives termed cetane improvers are known to reduce $\mathrm{NO}_{\mathrm{x}}$ emissions in petrodiesel.

\section{Objectives:}

- Identify and evaluate biofuel formulations consisting of fat and oil derived products with improved combustion properties and exhaust emissions.

Status: September 1994-June 1996

Accomplishments:

- Determined the CNs of various fatty compounds and of various potential cetane improving additives.

- Found that some cetane improvers have significant potential for use in alternative diesel fuels obtained from vegetable oils and their derivatives.

- In some cases, the acids now had higher $\mathrm{CNs}$ than the esters, a reversal of previously known effects.

- The observations offer the possibility to tailor the cetane improver to the predominant fatty compound in a mixture.

- Precombustion samples of various fatty acids and esters were collected and are being analyzed.

Participants: U.S. Department of Agriculture-Agricultural Research Service, National Center for Agricultural Utilization Research, Southwest Research Institute

Sponsoring Organization(s): U.S. Department of Agriculture-Agricultural Research Service, National Center for Agricultural Utilization Research

Point of Contact: Gerhard Knothe, USDA-ARS, National Center for Agricultural Utilization Research, 1815 North University Street, Peoria, IL 61604; phone 309.681.6417, fax 309.681.6340, e-mail knothegh@mail.ncaur.usda.gov

Paper(s): None available at this time

Additional Information: ARS Project No. 3620-41000-075-01G; CRIS accession \#9147020 


\section{Project Title:}

Low-Temperature Filterability Properties of Altemative Diesel Fuels from Vegetable Oils

Background: Methyl esters from vegetable oils have many characteristics that make them attractive altemative fuels for combustion in $\mathrm{Cl}$ (diesel) engines. Recent research has shown that the issue of cold flow properties should be resolved before methyl esters will be an attractive altemative fuel in moderate temperature climates.

\section{Objectives:}

- Investigate the low-temperature flow properties of neat methyl esters.

- Investigate the apparent effects of methyl esters in middle distillates to understand how low-temperature flow properties of blends are affected by the presence of methyl esters.

- Investigate techniques that improve the cold flow properties of methyl esters and that are likely to be effective in blends.

Status: 1996

\section{Accomplishments:}

- The research determined that the filterabilities (CFPP and LTFT) of SME, TME, and SME/TME admixtures without additives showed a linear correlation with $C P$.

- Statistical analysis determined that LTFT and CFPP may be estimated directly from the CP.

- This work also shows that thermal analysis is crucial to the development of altemative diesel fuels from fats and/or vegetable oils in at least the following two areas:

1. Fundamental studies of the nucleation, growth, and agglomeration as well as morphology of fatty methyl esters and other derivatives.

2. Identification and evaluation of approaches for improving low-temperature flow properties of fatty methyl esters and other derivatives.

Participants: U.S. Department of Agriculture-Agricultural Research Service, National Center for Agricultural Utilization Research, National Biodiesel Board, and Interchem Environmental

Sponsoring Organization(s): National Biodiesel Board

Point of Contact: Robert Dunn, USDA-ARS, National Center for Agricultural Utilization Research, 1815 N. University Street, Peoria, IL 61604, phone 309.681.6413, fax 309.681.6686, e-mail dunnro @mail.ncaur.usda.gov. Ms. Bev Thessen, National Biodiesel Board, P.O. Box 104898, Jefferson City, MO, 65110-4898, phone 573.635.3893, fax 573.635.7913, e-mail biodiesel@sockets.net.

\section{Paper:}

Dunn, R.O.; Bagby, M.O. (1996). "Low-Temperature Filterability Properties of Alternative Diesel Fuels from Vegetable Oils." Proceedings of the Third Liquid Fuel Conference; September 15-17, 1996. St. Joseph, MI: The American Society of Agricultural Engineers, pp. 95-103. 


\section{Project Title:}

Low-Temperature Properties of Triglyceride-Based Diesel Fuels: Transesterified Methyl Esters and Petroleum Middle Distillate/Ester Blends

Background: The notion of developing alternate or emergency diesel fuels from plant oils and/or animal fats (triglycerides) has been around for some time. Triglycerides have many fuel-related physical properties that compare well with middle distillates, properties that include gross hearts of combustion and cetane ratings.

\section{Objectives:}

- This work examines the low-temperature properties of triglyceride-based alternate fuels for direct-injection $\mathrm{Cl}$ engines.

- Methyl esters from transesterified soybean oil were studied as neat fuels and in blends with petroleum middle distillates (No. 1 or No. 2 diesel fuels) to determine PP, CP, and kinematic viscosities.

Status: February 1995

\section{Accomplishments:}

- The petroleum industry routinely uses PPs and CPs to characterize low-temperature properties of diesel fuels. For blends containing as little as 10 volume \% esters, both PP and CP were significantly affected.

- From the practical standpoint of clod-flow properties, this results demonstrate the limitation of blending methyl esters with middle distillates.

- For blends with at least $50 \%$ (by volume) methyl esters, the nature of the remaining liquid portion of the mixture relative to precipitation is nearly independent of the grade of distillates.

Participants: Oil Chemical Research, U.S. Department of Agriculture-Agricultural Research Service, National Center for Agricultural Utilization Research

Sponsoring Organization(s): Oil Chemical Research, U.S. Department of AgricultureAgricultural Research Service

Point of Contact: Robert Dunn, USDA-ARS, National Center for Agricultural Utilization Research, 1815 N. University Street, Peoria, IL 61604, phone 309.681.6413, fax 309.681.6686, e-mail dunnro@ mail.ncaur.usda.gov

\section{Paper:}

Dunn, R.O.; Bagby, M.O. (1996). "Low-Temperature Filterability Properties of Alternative Diesel Fuels from Vegetable Oils." Proceedings of the Third Liquid Fuel Conference; September 15-17, 1996. St. Joseph, Ml: The American Society of Agricultural Engineers; pp. 95-103. 


\section{Project Title:}

\section{National Altemative Fuels Laboratory--Phase V}

Background: This project was designed to perform "load and purge" testing of commercial sorbents with oxygenated and base-fuels. It will also analyze sorbent breakthrough vapors with Fourier transform infrared spectroscopy (FTIR) analysis, heat biodiesel samples in simulated fuel injector according to specific temperature program, and analyze and compare before-and after-heating fuel samples with gas chromatography/ mass spectrometry, mix a series of ethanol-gasoline blends of increasing ethanol concentration using ethanol denatured with different chemicals and analyze fuels with FT-K and publish research results in scientific joumals and present findings and other biomass-derived fuel information at meetings and conferences.

\section{Objectives:}

- Evaluate and compare automobile fuel evaporation canister sorbent performance with vapors from oxygenated (with alcohols and ethers) fuels and base fuels.

- Investigate chemical stability of biodiesel fuels at vehicle engine fuel-injection temperatures;

- Evaluate effect on Reid vapor pressure of hydrogen bonding between ethanol molecules in ethanol-blended gasolines.

- Disseminate research results and other information on biomass-derived fuels.

Status: May 1995-April 1996

Accomplishments: Recent NAFL research on how the performance and capacity of fuel evaporation canister sorbents are affected by vapors from ethanol blends indicated that ethanol vapor breakthrough occurs significantly later than gasoline hydrocarbon vapor breakthrough. Findings from the work are reported in SAE Paper No. 952748 (see Section 87). Because of published fuel volatility work, the NAFL was contacted by the South Dakota State University Aviation Education Department to develop an ethanol-based fuel for piston engine aircraft (representing an annual market of about 650 million gallons). The NAFL has been working with a major oil company to obtain samples of refinery streams that meet economic and chemical criteria. Preliminary volatility and octane-rating test results are positive and indicate high viability of a blend of approximately $85 \%$ ethanol and $15 \%$ pentane isomerate (a relatively high-volatility gasoline blend stock).

Participants: Energy \& Environmental Research Center, University of North Dakota,

Sponsoring Organization(s): U.S. Department of Agriculture-Cooperative State Research, Education, and Extension Service

\section{Point of Contact:}

C.L. Knudson, Energy \& Environmental Research Center, University of North Dakota, Grand Forks, ND 58202, phone 701.777.3341.

\section{Papers:}

Grisanti, A.A.; Altlich, T.R.; Knudson, C.L. (1995). "Gasoline Evaporative Emissions-Ethanol Effects on Vapor Control Canister Sorbent Performance." In Proceedings of the 1995 Society of Automotive Engineers International Fuels Conference. 
Kellner, T., K. Neusen, D. Bresenham, M. Pike, D. Rose. (University of Wisconsin at Milwaukee-Center for Altemative Fuels), "Laboratory Study of the Effects of Reformulated Gasoline on Motor Vehicle Fuel Economy in Southwestem Wisconsin."

Gerlach, T.R. "Ethanol Work at the EERC National Altemative Fuels Laboratory," ACE Pace Newsletter 1996, Spring (American Coalition for Ethanol. Sioux Falls, South Dakota).

Gerlach, T.R. and T.R. Aulich. "The Energy \& Environmental Research Center National Alternative Fuels Laboratory," The Energy Independent 1996, May (Bryan \& Bryan Incorporated, Cotopaxi, CO).

Gerlach, T.R. and T.R. Aulich. "Red River Valley Clean Cities to Anchor Northern End of Midcontinent Trade Corridor," Drive, U.S. Department of Energy Clean Cities Program, Alternative Fuels Division of the National Renewable Energy Laboratory.

Additional Information: CRIS Accession No.: 91722542 


\section{Project Title:}

National SoyDiesel Development Board Standards for Biodiesel

Background: Biodiesel is a clean-buming, renewable, nontoxic, biodegradable, and environmentally friendly transportation fuel. In the United States, commercialization of biodiesel is supported by oilseed and other potential biodiesel feedstock producers and processors. The NBB was formed to develop fuel standards for biodiesel and to determine the engine performance and emissions standards for this fuel.

Objective: To ensure successful marketing of SoyDiesel and biodiesel.

Status: Completed 1993

\section{Accomplishments:}

- This project provided supported regulatory and legislative analysis of policies pertaining to motor fuels that could affect biodiesel.

Participants: American Biofuels, Information Resources, Inc., National Biodiesel Board

Sponsoring Organization(s): National Biodiesel Board

Point of Contact: William Holmberg, American Biofuels Association, 1925 N. Lynn Street, Suite 1050, Arlington, VA 22209; phone 703.522.3392, fax 703.522.4193.

Paper(s):

Holmberg, W.C.; Gavett, E.E.; Merrill, P.N.; Peeples, J.E. (1993). "National SoyDiesel Development Board Standards for Biodiesel" Proceedings of the First Biomass Conference of the Americas: Energy, Environment, Agriculture, and Industry, vol. II, August 30-September 2, Burlington, VT. Golden: The National Renewable Energy Laboratory, pp. 876-890. 


\section{Project Title:}

Nonfood Agricultural Products Project

Background: A market analyst will be hired to help the interim director identify niche markets for products developed from agricultural commodities and processes developed for isolating, converting, and using products. Research will be initiated in the area of incorporating starch into plastic films and a process for making starch-based foam plastic products will be scaled up. A demonstration unit for expressing oil from crambe seed and possibly milkweed seed will be developed. Improvement of the fermentation process for producing ethanol and the downstream processing of ethanol will be studied. Use of nonconventional feedstocks will be an emphasis. New fuels will be tested as they are developed for engine compatibility.

\section{Objectives:}

- Identify niche markets for industrial use of agricultural-based products.

- Improve and develop conversion processes as needed for specific product isolation and use.

- Provide technical, marketing, and business assistance to industries.

The specific program areas identified for initial emphasis are polymer products such as starchbased and protein-fortified plastics, oil-based products such as high-erucic acid oils and microemulsion fuels, fermentation products such as ethanol and ETBE, and meat animal byproducts such as hides and rumen contents.

Status: January 1993-October 1994.

\section{Accomplishments:}

This project has had specific annual goals pertaining to development of starch-based plastic foams, protein films, com-whey fermentations, acetone-butanol-ethanol fermentations/ separations, and beef tallow and soybean oil biodiesel fuels. Although most of these projects have not been completed, several significant accomplishments can be identified:

- A patent is pending on a starch-based plastic foam.

- A patent application is being prepared on a continuous com-whey fermentation process.

- A continuous starch liquefaction process has been developed for use in fermentation processes.

- Significant grant support has been obtained as a result of start up funding through this project.

- Significant progress has been made on

(a) protein films

(b) emissions testing of biodiesel fuels

(c) use of soybean oil as a drip oil for irrigation pumps

(d) membranes for improved fermentation separations.

Participants: Industrial Agricultural Products Center, University of Nebraska, U.S. Department of Agriculture-Cooperative State Research, Education, and Extension Service

Sponsoring Organization(s): U.S. Department of Agriculture-Cooperative State Research, Education, and Extension Service, Nebraska

Point of Contact: Milford Hanna, Director, Industrial Agricultural Products Center, 211 LW Chase Hall, University of Nebraska-Lincoln, Lincoln, NE 68583-0730, phone 402.472.1624. 


\section{Papers:}

Ali, Y. and M.A. Hanna (1994). "Physical Properties of Tallow Ester and Diesel Fuel Blends." Bioresource Technology 47:131-134.

Bhatnagar, S. and M.A. Hanna (1995). "Physical, Mechanical, and Thermal Properties of Starch-Based Plastic Foam." Trans. of the ASAE. Accepted Dec. 15, 1994.

Qureshi, N., M.M. Meagher, and R.W, Hutkins (1994). "Recovery of 2,3-Butanediol Byvacuum Membrane Distillation." Sep. Sci. Technol. 29:1733-1748.

Zhou, K.P., H.H. Yang, and K.M. Shahani (1993). "Ethanol Production by Continuous Cofermentation of Whey and Com." Presented at Tenth International Symposium on Alcohol Fuels, Colorado Springs, CO. Nov. 7. 


\section{Project Title:}

Oxidative and Thermal Stability Testing Method(s) for Biodiesel

Background: A lack of applicable test methods for oxidative stability needs to be resolved to arrive at proper ASTM certification for biodiesel. At present, European and some U.S. engine manufacturers are using the iodine value as an indicator of oxidative stability. The iodine value measures the total number of double bonds in the fatty acid chain without respect as to how they are distributed among or within the chains or the impact of the double bonds on fuel stability-related properties.

\section{Objectives:}

- Provide documentation for selecting stability methods for biodiesel by conducting a literature search on the importance of oxidative and thermal stability of fuel on diesel engine performance.

- Identify and evaluate potential analytical measurement techniques for oxidative and thermal stability.

- Perform limited proof-of-concept bench scale testing of recommended methods.

- Develop a round-robin test matrix protocol that will correlate test results obtained by the selected analytical methods with actual fuel injection equipment and engine performance in the field.

Status: July 1997-June 1998

Accomplishments: Work in progress

Participants: National Renewable Energy Laboratory, National Biodiesel Board, and Southwest Research Institute

Sponsoring Organization: U.S. Department of Energy Office of Fuels Development

Point of Contact Dr. K. Shaine Tyson, National Renewable Energy Laboratory, 1617 Cole Blvd., Golden, CO 80401, phone 303.275.4616, fax 303.275.4675, e-mail

tysonk@tcplink.nrel.gov.

\section{Papers:}

Oxidative Stability Literature Review Report (forthcoming)

Potential Analytical Measurement Techniques for Oxidative and Thermal Stability Report (forthcoming) Recommended Rating System and Analysis Report (forthcoming) Recommendations for Stability Method(s) for Biodiesel, Letter Report (forthcoming) Round-Robin Test Protocol Report (forthcoming) 


\section{Project Title:}

Properties of Altemative Fuels

Background: The passage of EPAct generated a need for sound information on alternative transportation fuels to enable fleet managers to make intelligent choices when deciding how to comply with the Act. Little comparitive information was available to help fleet managers understand the properties of various altemative fuels. The lack of information on this topic was the genesis of this project.

Objective: To provide data on the properties of various fuels, including biodiesel.

Status: Part of a multiyear contract.

Accomplishments:

- Study prepared in 1994.

Participants: Battelle Memorial Labs, Federal Transit Administration, Office of Technical Assistance

Sponsoring Organizations(s): Federal Transit Administration, Office of Technical Assistance and Safety

Point of Contact: Michael J. Murphy, Battelle Memorial Labs, 505 King Avenue, Columbus, $\mathrm{OH}$ 43201-2693, phone 614.424.4846, fax 614.424.5069.

\section{Papers:}

Properties of Alternative Fuels, October 1994. 


\section{Project Title:}

Rapeseed and Safflower Oils as Diesel Fuels

Background: During the past decade the United States has become increasingly dependent upon imported oil to meet our energy demands. Nearly $50 \%$ of our petroleum is imported. Research has shown that agricultural crops can be used to reduce this dependence. The University of Idaho research team has pioneered the use of rapeseed oil as a diesel fuel substitute. This project, aimed for use of safflower oil in railroad engines, involves genetics, agronomics, economics, and contract engine testing.

\section{Objectives:}

- Research more cost-effective breeding for specific oil components and improve coproducts.

- Seek havester methods that will reduce seed dame.

- Investigate ways to extract faster for more complete oil.

\section{Status: Completed}

\section{Accomplishments:}

- The diesel-fueled engine had the most power at first, and the totally ester-fueled engine the least, but by the end of the test, both biodiesel and a half-and-half fuel were producing more power than petroleum diesel.

- Fewer wear particles of iron, aluminum, chromium, and lead were found in the lube oil of biodiesel-fueled engines, possibly because of different combustion-chamber pressures.

- The diesel-fueled engine had more deposits on valve seats and heavier black deposit in combustion chamber. Piston rings were equally free in all engines; oil rings on the dieselfueled engine had more deposit.

- There were no significant problems in producing the amount of biodiesel used in the tests.

Participants: University of Idaho

Sponsoring Organization(s): University of Idaho

Point of Contact: Dr. Charles Peterson, Department of Agricultural Engineering, University of Idaho, Moscow, ID 83844, phone 208.885.7906, fax 208.885.8923, e-mail

peterson@novell.uidaho.edu.

Paper(s):

Peterson, C.L.; Haines, H.; Chase, C. (1993). Rapeseed and Safflower Oils as Diesel Fuels. Proceedings of the First Biomass Conference of the Americas: Energy, Environment, Agriculture, and Industry, vol. II, August 30-September 2, Burlington, VT. Golden: The National Renewable Energy Laboratory; pp. 922-927. 


\section{Project Title:}

Rapeseed as an Agricultural Fuel

Background: Not available.

Objectives:

- Develop higher yielding rapeseed cultivators with fatty acid composition suitable for diesel fuel and coproducts.

- Develop more efficient and environmentally acceptable processes for converting rapeseed oil to diesel fuel and associated coproducts.

- Develop more efficient methods and technology for storing, handling, and using diesel fuel from rapeseed.

- Assess economic costs and potential benefits associated with producing and using rapeseed oils as a fuel extender.

Status: 1993

\section{Accomplishments:}

- Two winter plant selections have been identified that have high seed yield, high percentage of oil content, and very high levels of erucic acid.

- Conducted on-road test with two pickups operating on biodiesel blends

Participants: University of Idaho, U.S. Department of Agriculture-Agricultural Research Service

Sponsoring Organization(s): University of Idaho, U.S. Department of Agriculture-Agricultural Research Service

Point of Contact: Dr. Charles Peterson, Department of Agricultural Engineering, University of Idaho, Moscow, Idaho 83844, phone 208.885.7906, fax 208.885.8923, e-mail

peterson@ novell.uidaho.edu.

Paper(s):

Peterson, C.L.; Brown, J.; Guerra, D.; et al. (1993). Rapeseed Oil as Diesel Fuel an Overview. Proceedings of the First Biomass Conference of the Americas: Energy, Environment, Agriculture, and Industry, vol. II, August 30-September 2, Burtington, VT. Golden: The National Renewable Energy Laboratory; pp. 916-921. 


\section{Project Title:}

\section{Tallow/Diesel Blend}

Background: ORTECH was contracted to evaluate a $20 \% / 80 \%$ tallow/diesel blend in a DDC $6 \mathrm{~V}-92 \mathrm{TA}$ engine. The work was carried out in conjunction with another project, which was conducted at ORTECH for Fosseen Manufacturing and Development.

Objective: To document emissions, specifically $\mathrm{NO}_{x}$, at steady-state and transient conditions.

Status: July 1993

Accomplishments:

- For both rated power and peak torque, a small drop in power and torque, respectively, was observed.

- THC and CO showed trends toward a reduction similar to the finding with the biodiesel blends.

Participants: ORTECH, Fosseen Manufacturing and Development

Sponsoring Organization(s): Fosseen Manufacturing and Development

Point of Contact: Wendel Goetz, Transportation Systems, ORTECH International, 395 Speakman Drive, Mississauga, ON L5K 1B3, phone 905.822.4111, fax 905.823.1446.

\section{Paper(s):}

Goetz, W. (July 1993). Evaluation of a Tallow/Diesel Blend in a DDC 6V-92TA Engine. Radcliffe, IA: Fosseen Manufacturing \& Development. Work performed by Ortech International, Mississauga, Ontario 
Project Title:

The Influence of Various Oxygenated Compounds on the Cetane Numbers of Fatty Acids and Esters

Background: $\mathrm{CN}$ is one of the prime indicators of the quality of a diesel fuel. Two compounds have been selected as references for the cetane scale.

\section{Objectives:}

- Determine the relative CNs of several esters of some common acids.

- Investigate the influence of potential cetane-improving additives.

Status: Completed

Accomplishments:

- The CNs of fatty compounds depend on their structure.

- Three is great potential for improving the $\mathrm{CN}$ and the combustion of fatty compounds by means of such oxygenated additives.

Participants: Southwest Research Institute

Sponsoring Organization(s): U.S. Department of Agriculture

Point of Contact: Gerhard Knothe, U.S. Department of Agriculture-Agricultural Research Service, National Center for Agricultural Utilization Research, 1815 North University Street, Peoria, IL 61604, phone 309.681.6417, fax 309.681.6340, e-mail

knothegh@mail.ncaur.usda.gov

Paper(s):

Knothe, G.; Bagby, M.O.; Ryan, T.W. III. (1996). "The Influence of Various Oxygenated Compounds on the Cetane Numbers of Fatty Acids and Esters." Proceedings of the Third Liquid Fuels Conference, September 15-17, Nashville, TN. Liquid Fuels and Industrial Products from Renewable Resources, pp. 54-58. 


\section{Project Title:}

The Physical Characterization of Biodiesel/Low Sulfur Diesel Fuel Blends

Background: The possibility of a biodiesel and low-sulfur diesel blend being classified as an alternative fuel calls for detailed information on physical- and chemical-fuel blends ranging from $100 \%$ biodiesel to $100 \%$ low-sulfur diesel fuel.

\section{Objectives:}

- Analyze fuel related variables for blends of $20 \%, 30 \%, 50 \%$, and $70 \%$ biodiesel/diesel fuel blends.

- Determine whether the fuel analysis yields a linear response when compared to $100 \%$ biodiesel and $100 \%$ diesel fuel.

- Identify a range of values that can be expected for various fuel related variables when analyzing blends of biodiesel and diesel fuel.

Status: Completed December 30, 1995

\section{Accomplishments:}

- The various blends of biodiesel and low-sulfur diesel were systematically characterized, and correlations between the fuel properties were derived.

- The physical and chemical characteristics were tabulated for each fuel blend.

- The analysis determined that simple mathematical interpolation methods could be used to predict some of the fuel blends' characteristics.

Participants: Cleveland Technical Center, MFA Oil Company, University of MissouriDepartment of Agricultural Engineering, and U.S. Environmental Protection Agency

Sponsoring Organization(s): National Biodiesel Board, University of Missouri Department of Agricultural Engineering

Point of Contact: Ms. Bev Thessen, National Biodiesel Board, P.O. Box 104898, Jefferson City, MO, 65110-4898, phone 573.635.3893, fax 573.635.7913, e-mail biodiesel@ sockets.net.

\section{Paper:}

Schumacher, L. (1995). The Physical and Chemical Characterization of Biodiesel/Low Sulfur Diesel Fuel Blends. NBB \# 52019-1. Jefferson City, MO: National Biodiesel Board. 


\section{Project Title:}

Transesterification Process to Manufacture Ethyl Ester of Rape Oil

Background: A process for the production of the ethyl ester of winter rape for use as a biodiesel fuel has been studied. The essential part of the process is the transesterification of rape oil with ethanol, in the presence of a catalyst, to yield the ethyl ester.

Objectives: To optimize conditions for the transesterification of rape oil to produce ethyl ester of winter rape.

Status: Completed

Accomplishments:

- The economic viability of REE can be improved if lower-value oil feedstocks can be obtained.

- Conditions were identified that ensure the successful completion of the transesterification process.

Participants: University of Idaho

Sponsoring Organization(s): U.S. Department of Agriculture-Agricultural Research Service

Point of Contact: Dr. David Drown, 308 Buchanan Engineering Lab, Chemical Engineering Dept, University of Idaho, Moscow, ID 83844-1021, phone 208.885.7848, fax 208-885-7467, email ddrown@uidaho.edu

Paper:

Korus, R.A.; Hoffman, D.S.; Peterson, C.L.; et al. (1993). Transesterification Process to Manufacture Ethyl Ester of Rape Oil. Proceedings of the First Biomass Conference of the Americas: Energy, Environment, Agriculture, and Industry, vol. II, August 30-September 2, Burlington, VT. Golden: The National Renewable Energy Laboratory; pp. 815-826. 


\section{Project Title:}

Vegetable Oils as Altemative Diesel Fuels

Background: After the fuel crises of the 1970s and 1980s, vegetable oils and derivatives thereof were among the materials extensively investigated as alternative diesel fuels. The multitude of problems associated with the use of vegetable oils, however, has up to the present time prevented their use as a fuel in diesel engines. Besides their current noncompetitive price, vegetable oils used in a diesel engine create a variety of practical problems largely resulting from incomplete combustion but characterized by nozzle choking, engine deposits, lube oil dilution, ring sticking, and lubricant failure due to polymerization of the vegetable oil. Despite these drawbacks, vegetable oils have remained attractive candidates as alternative diesel fuels because they are renewable resources with relatively high heat values.

\section{Objectives:}

- Study in detail the chemistry of vegetable oils under conditions in a diesel engine.

- Study the reactions occurring during this precombustion phase.

Status: 1992

\section{Accomplishments:}

- Researchers found that reaction rates are very high.

- They noticed better than expected ignition quality of the triglycerides.

- The results showed that compounds found in the emissions of diesel engines can arise during the precombustion phase in a diesel engine and survive it.

Participants: Southwest Research Institute

Sponsoring Organization(s): U.S. Department of Agriculture, Southwest Research Institute

Point of Contact: Gerhard Knothe, U.S. Department of Agriculture-Agricultural Research Service, National Center for Agricultural Utilization Research, 1815 North University Street, Peoria, IL 61604; phone 309.681.6417, fax 309.681.6340, e-mail

knothegh@mail.ncaur.usda.gov

\section{Paper(s):}

Knothe, G.; Bagby, M.O.; Ryan, T.W.; Callahan, T.J.; Wheeler, H.G. (1992). "Vegetable Oils as Alternative Diesel Fuels: Degradation of Pure Triglycerides during the Precombustion Phase in a Reactor Simulating a Diesel Engine. Alternative Fuels for $\mathrm{Cl}$ and SI Engines (SP900); February 24-28, Detroit MI. SAE \# 920194. Warrendale, PA: Society of Automotive Engineers, pp. 37-63. 


\section{B. Material Compatibility}

Also see the following projects:

Error! Reference source not found.

Third Workshop: Commercialization of Biodiesel: Producing a Quality Fuel 
Project Title:

Materials Compatibility, Fuel Blend Characteristics, Engine Dynamometer Evaluation

Background: After reviewing available literature, it was determined that field testing was necessary to verify the apparent compatibility of materials with $20 \%$ and $30 \%$ biodiesel.

\section{Objectives:}

- Examine the compatibility of neat biodiesel and biodiesel blends with materials commonly encountered in storage and fuel systems.

- Examine fuel blend characteristics in terms of filterability, emulsification, storage/thermal stability, lubricity, inspection, and compatibility in blends, with additives, or as a mix. A tenfuel matrix is being evaluated that included neat biodiesel, low-sulfur diesel, off-road diesel, and JP-8.

Status: July 1994-May 1996.

\section{Accomplishments:}

- Storage of neat biodiesel showed property changes in elastomers, and coating of metal coupons with corrosive properties when stored with biodiesel blends. Further testing will be performed to determine fuel blend characteristics.

- After 3 months of storage, several of the samples are showing sediment formation and fuel discoloration. Some brass and copper coupons are being coated with corrosion-like products when stored with biodiesel blends.

- Fuel filters form the DDC 6V-53T engine, GM 6.2L engine, and the coalescer and separator filters from the M1A1 are being stored for $0,1,3$, and 6 months at $52^{\circ} \mathrm{C}\left(125^{\circ} \mathrm{F}\right)$. Flow and filter efficiency will be determined after storage with the test fuels.

Participants: Department of the Army-Mobility Technology Center, Tank Automotive Research Development Engineering Center (TARDEC), Fuels and Lubricants Facility at SwRI

Sponsoring Organization: U.S. Department of Agriculture-Cooperative State Research, Education, and Extension Service

Point of Contact: Edward A. Frame, TARDEC Fuels and Lubricants Research Facility, Southwest Research Institute, 6220 Culebra Road, San Antonio, TX 78238-5100, phone 210.684.2515, fax 210.522.3270, e-mail eframe@ swri.org

\section{Papers:}

Frame, E.A. (May 1996). Investigation of Biodiesel Fuel Technology for Military Application. U.S. Army TARDEC Fuels and Lubricants Research Facility. Work performed by Southwest Research Institute, San Antonio, TX.

Frame, E.A., G.B. Bessee, and H.W. Marbach, Jr. (1997) Biodiesel Fuel Technology for Military Application--Interim Report. Published by TARDEC Fuel s and Lubricants Facility at Southwest Research Institute (TF-LRF, No. 317), San Antonio, TX.

Bessee, G.B. and J.P. Frey. (1997) Compatibility of Elastomers and Metals in Biodiesel. SAE Paper No. 971690. 


\section{Wear Lubricity}

Also see the following projects:

Altemative Fuels and Lubricants from Rapeseed

Error! Reference source not found.

Industrial Agricultural Products Center

Materials Compatibility, Fuel Blend Characteristics, Engine Dynamometer Evaluation

Third Workshop: Commercialization of Biodiesel: Producing a Quality Fuel 


\section{Project Title:}

Biodiesel Lubricity Quantification--Low Blends

Background: In some diesel engines, the diesel fuel is used as the means to provide lubrication of some of the moving parts, mainly rotary fuel pumps. The 1993 introduction of low-sulfur diesel caused a series of problems, some of which were poor lubricity. However, research has indicated that biodiesel has significant lubricity benefits. This research examines the lubricity of low-level biodiesel blends and compares the results to commercial lubricity additives.

Objective: To define the effects of increasing concentration of biodiesel on various diesel fuels available in the market today using the latest lubricity test methods available in 1997.

Status: Extended to September 30, 1997

\section{Accomplishments:}

- Biodiesel with both No. 1 and No. 2 diesel fuel showed substantial lubricity improvements with percentages of biodiesel below $1 \%$ using both the HFRR and the SLBOCLE.

- Results on blends of No. 1 and No. 3 diesel with biodiesel using the SLBOCLE were mixed--this is likely due to the inherent analytical variability associated with the test methods.

- Stannadyne, a leading diesel fuel pump manufacturer who ran the HFRR testing, suggested the addition of $2 \%$ biodiesel would solve the lubricity problems being experienced in petrodiesel fuels today.

Participants: Williams Pipeline, National Biodiesel Board

Sponsoring Organization(s): National Biodiesel Board

Point of Contact: Ms. Bev Thessen, National Biodiesel Board, P.O. Box 104898, Jefferson City, MO, 65110-4898, phone 573.635.3893, fax 573.635.7913, e-mail biodiesel@ sockets.net.

Paper: Under review. 


\section{Project Title:}

Biodiesel Lubricity--1993

Background: Failures resulting from the introduction of low-sulfur (0.05\%, down from $0.5 \%)$ diesel fuel in 1993 have been attributed to poor fuel lubricity. Others have attributed the problem to a material compatibility problem with various gaskets. This project set out to determine the latest technical information on the causes of the problems, and biodiesel's potential impact in providing solutions.

\section{Objectives:}

- Provide the biodiesel industry with quantification of the lubricity properties of biodiesel and biodiesel blends in order to address the concerns of lubricity and pump failures with recent low-sulfur diesel fuel.

- Provide an analysis of the likely effects of biodiesel on gasket swelling or shrinkage.

- Compare these results with those of conventional low-sulfur diesel to determine whether there is any lubricity, component wear, or gasket swelling competitive advantage for biodiesel blends.

\section{Status: October 1994}

\section{Accomplishments:}

- Using the 1993 version of the Ball on Cylinder Lubricity Evaluator, test results showed a substantial lubricity improvement with as little as $10 \%$ biodiesel. Results at blends lower than $10 \%$ were inconclusive.

- Some diesel problems have been attributed to the shrinkage of fuel pump gaskets when exposed to low-sulfur diesel, resulting in serious leakage. Further study is needed to determine biodiesel's effect on these particular gaskets.

- Although gasket shrinkage is responsible for some problems experienced in 1993-1994, poor fuel lubricity is also causing increased pump wear and maintenance according to fuel pump manufacturers.

Participants: MARC-IV Consulting, Inc and University of Missouri

Sponsoring Organization(s): National Biodiesel Board

Point of Contact: Steve Howell, MARC-IV Consulting, Inc, 16200 Northridge Road, Keamey, MO, 64060, phone 816.635.5772, fax 816.635.4836, e-mail showell@marciv.com. Ms. Bev Thessen, National Biodiesel Board, P.O. Box 104898, Jefferson City, MO, 651104898, phone 573.635.3893, fax 573-635-7913, e-mail biodiesel@ sockets.net.

\section{Paper:}

Howell, S.A. (1995); "Lubricity, The Biodiesel Advantage." ASAE Annual International Meeting, June 18-23, 1995, MARC-IV Consulting, Inc, Kearney, MO.

Schumacher, L.G.; Howell, S.A. (1994). "Lubricating Qualities of Biodiesel and Biodiesel Blends." Proceedings of the 6th National Bioenergy Conference, vol. I, Bioenergy '94, RenoSparks, NV. Westem Regional Biomass Energy Program, pp. 113-119. 


\section{Project Title:}

Engine Oil Literature Search and Summary

Background: Engine manufacturers desire further information on the use of biodiesel as it relates to engine oil viscosity, acidity, and dilution. This research project was designed to compile the available data relating to biodiesel's impact on engine oil parameters.

\section{Objectives:}

- Review biodiesel research available from the NBB field demonstrations, ASAE, SAE, and other sources relating to analysis of engine lubricating oil while engines were fueled on biodiesel or biodiesel blends.

- Analyze the research for its technical accuracy and validity.

- Identify the methodology for testing engine oil dilution and its applicability to biodiesel.

- Provide a project included summarizing all engine oil testing analyses.

Status: September 1, 1996-August 31, 1997

\section{Accomplishments:}

- All biodiesel research available from the NBB and other biodiesel-related research was reviewed.

- The technical accuracy of the historical research on engine lubricating oil by the aforementioned groups was determined.

- In cooperation with engine analysis laboratories, researchers identified the appropriate methodology to analyze engine lubricating oil diluted with biodiesel.

Participants: State of Indiana and University of Missouri-Columbia

Sponsoring Organization(s): National Biodiesel Board and the State of Indiana

Point of Contact: Ms. Bev Thessen, National Biodiesel Board, P.O. Box 104898, Jefferson City, MO, 65110-4898, phone 573.635.3893, fax 573.635.7913, e-mail biodiesel@ sockets.net; Dr. Leon Schumacher, University of Missouri Columbia, 235 Agricultural Engineering Bldg., Columbia, MO 65211, phone 573.882.2126, fax 573.884.5650, e-mail leon schumacher@muccmail.missouri.edu.

\section{Paper:}

Schumacher, L.G. (1996). Engine Oil Impact Literature Search and Summary. NBB: 96-218. Jefferson City, MO: National Biodiesel Board. 


\section{Project Title:}

Program Management and Planning for Advanced Materials from Renewable Resources

Background: This project encompassed a number of research areas including biodiesel, functional fluids, lubricants, surfactants, as well as the production of nylon 13,13, from high erucic acid oils.

\section{Objectives:}

- Develop and manage industrial use programs primarily for use of oil seed materials for the production of products to include biodiesel fuels, functional fluids, lubricants, and surfactants.

- Facilitate functional testing of these materials, particularly by the military.

- Conduct pilot plant process scale-up for the production if nylon 13,13 from high erucic acid oils.

Status: Project was initiated in September 1993 and is scheduled to be completed in September 1997.

Accomplishments: Work under this project included:

- Represented CSREES and its contractors to the NBB at its meetings and functions.

- Worked with the Army Tank/Automotive Command on the use of biodiesel and oilseed derived lubricants in military applications, and interacted with USDA subcontractors with the AMRR Program.

- Reviewed the Department of Defense "Green Book" for opportunities for placement of agriculturally derived industrial products into the military market and representing the CSREES in an intemational delegation studying the edible oils industry in the People's Republic of China.

- Designed and constructed a motionless mixer loop reactor system for the production of fatty acid esters and diacids, measurement of engineering properties for fatty acid methyl esters, and production of polyesters from vegetable oils.

Participants: Biological Systems Engineering and University of Nebraska, Lincoln

Sponsoring Organization(s): U.S. Department of Agriculture-Cooperative State Research, Education, and Extension Service

Point of Contact: L.D. Clements, Biological Systems Engineering, University of Nebraska, Lincoln, NB, phone 402.472.0177.

\section{Papers:}

Pickrell, A.M. and L.D. Clements (1995). "Modeling of soybean oil bleaching using a surface diffusion relationship." Submitted to Joumal of American Oil Chemists' Society. 


\section{Project Title:}

Small Engine Lubrication Oil Testing Two Cycle Outboard Engines

Background: When using outboard motors, petroleum products are discharged directly into water, thus having a negative environmental impact. Testing on biodiesel oil as a replacement for petroleum based products would help to reduce this environmental hazard.

\section{Objectives:}

- Study and evaluate the opportunity for using methyl soyate as a $100 \%$ replacement of petroleum-derived lubrication oils in small two cycle outboard engines.

- Evaluate the differences in water dispersion and bio-degradability of a commercial petroleum two-cycle lubricating oil and SME.

Status: Completed on October 31, 1994

\section{Accomplishments:}

- The research found engines operating on SME ran for only 9 hours before the bottom piston lost compression because the SME dissolved the engine block sealant.

- The lubricity of SME was satisfactory and shows SME to be a viable altemate lubrication oil for use in two-cycle engines.

- Additional research needs to be conducted to make SMEs more chemically compatible and stable.

Participants: Brabmij Inc. and National Biodiesel Board

Sponsoring Organization(s): National Biodiesel Board

Point of Contact: Ms. Bev Thessen, National Biodiesel Board, P.O. Box 104898, Jefferson City, MO, 65110-4898, phone 573.635.3893, fax 573.635.7913, e-mail biodiesel @ sockets.net.

\section{Paper:}

Gardner, J.M. (1994). Small Engine Lubrication Oil Testing Two Cycle Outboard Engines

Final Report NBB No. 252-1. Jefferson City, MO: National SoyDiesel Development Board. 


\section{Project Title:}

The Relationship between Fuel Lubricity and Diesel Injection System Wear

Background: The U.S. Army is using highly refined aviation turbine fuels in its ground tactical fleet. Such fuels commonly have both decreased viscosity and lubricity when compared to diesel. There is currently no recognized standard to define the lubricity requirements of the injection systems on compression ignition equipment. However, increased failure rates reported during Operation Desert Shield/Storm, as well as the results of previous bench wear tests, indicate that there may be a problem.

\section{Objectives:}

- Develop bench tests reflecting the lubricity requirements of the fuel injection system.

- Define a minimum lubricity requirement.

Status: September 1, 1990-November 1, 1991 (January 1992 report)

\section{Accomplishments:}

- The durability of the Stanadyne fuel injection pump is highly dependent on fuel lubricity, and severe wear was observed with neat Jet $A-1$ at $170^{\circ} \mathrm{F}\left(77^{\circ} \mathrm{C}\right)$.

- The DCl-4A additive (equivalent to JP-8) measurably reduced fuel-related wear to a level similar to that seen with diesel.

- Use of low-viscosity fuels at high temperatures may contribute to hot-restart problems

Participants: Belvoir Fuels and Lubricants Research Facility of Southwest Research Institute

Sponsoring Organization(s): U.S. Amy Belvoir Research, Development and Engineering Center, Logistics Equipment Directorate

Point of Contact: P.I. Lacey, Belvoir Fuels and Lubricants Research Facility, Southwest Research Institute; 6220 Culebra Road, San Antonio, TX 78238-5166; T.C. Bowen, phone 703.664.3576.

\section{Paper(s):}

Lacey, P.I. (1992). The Relationship between Fuel Lubricity and Diesel Injection System Wear. DAAK 70-87-C0043. Fort-Belvoir, VA: U.S. Amy Belvoir Research, Development, and Engineering Center. Work performed by Belvoir Fuels and Lubricants Research Facility, Southwest Research Institute, San Antonio, TX. 


\section{Project Title:}

Use of Biodegradable, Seed-Based, Automotive Engine and Transmission Lubricants, Industrial Lubricants, and Chemical Additives

Background: The Alternative Agricultural Research and Commercialization (AARC) Corporation, a wholly owned government corporation of USDA, is a venture capital firm that makes investments in companies to help commercialize bio-based industrial products (nonfood, non-feed) from agricultural, forestry materials, and animal by-products. AARC is helping a company, International Lubricants, Incorporated, to develop new technologies using vegetable oil materials.

Objectives: To substitute vegetable oil materials such as crambe, rapeseed oil, and jojoba oil in place of automotive engine and transmission lubricants, industrial lubricants, and chemical additives.

Status: Ongoing marketing effort of a variety of biodegradable, seed-based automotive engine and transmission lubricants, industrial lubricants, and chemical additives.

\section{Accomplishments:}

- The company has a line of products available commercially including: Automatic Transmission Fluid, Bio/Tech Engine Protectant, Valve and Assembly Lubricant, All Purpose Lubricant, Gear Fluid Supplement, Two-Cycle Oil, Power Steering Fluid Supplement, Forming Paste, Water Soluble Cutting Oil, Hydraulic Fluid Supplement, Dry Film Lubricant, Gear Fluid Supplement, Wire Rope Lubricant, and other unlisted products.

- A research team, in conjunction with USDA, developed a revolutionary new technology using vegetable oil materials, Liquid Wax Esters, which have been proven to outperform sperm whale oil.

Participants: International Lubricants, Inc.

Sponsoring Organization(s): Alternative Agricultural Research and Commercialization Corporation, U.S. Department of Agriculture

Point of Contact: Ron Buckhalt, U.S. Department of Agriculture/AARC, 14th and Independence Avenue, S.W., Room 0156, South Building, Washington, D.C. 20250-0400, phone 202.690.1633. International Lubricants, Inc., 7930 Occidental South, Seattle, WA 98108, phone 206.762.5343.

\section{Papers:}

Source Book 1997. Alternative Agricultural Research and Commercialization Corporation.

Additional Information:

AARC Home Page: http://www.usda.gov/aarc. 


\section{Project Title:}

Use of Vegetable Oil as Fuel for Compression Ignition, Intemal Combustion Engines

Background: A truck with compression-ignition engine will be used for over-the-road and farm activities, Lubricating oil samples will be taken at regular intervals to identify unusual engine wear. Emission samples will be taken at regular intervals to evaluate air pollution. At the end of the test period, the engine will be disassembled to visually inspect for unusual wear. Fuel-heating devices, chemical additives, and diesel fuel blends will be investigated. A trailermounted system of equipment will be developed to esterify vegetable oil.

\section{Objective:}

- Evaluate effects of biodiesel fuel on engine wear over long-term, load-varying conditions.

- Develop equipment and techniques to facilitate low-temperature use of biodiesel.

- Develop equipment and procedure for esterifying soybean and canola oil.

Status: July 1991-December 1992.

Accomplishments: Esterified soybean oil has been successfully used as a diesel fuel replacement in pickup trucks and agricultural tractors. Emission measurements have been completed which indicate that esterified soybean oil (soydiesel or biodiesel) can be used in environmentally restricted areas where diesel fuel cannot. A demonstration unit consisting of a soydiesel-powered pickup, a gooseneck trailer, an agricultural tractor, and a portable dynamometer have been used throughout the state to demonstrate the effectiveness of soydiesel fuel. MFA Oil Company will begin merchandising soydiesel to farmers. This research has been instrumental in this marketing decision.

Participants: Food Science \& Engineering, University of Missouri

Sponsoring Organization(s): U.S. Department of Agriculture, Cooperative State Research, Education, and Extension Service, Missouri

Point of Contact: Dr. Leon Schumacher, University of Missouri Columbia, 235 Agricultural Engineering Bldg., Columbia, MO 65211, phone 573-882-2126, fax 573-884-5650, e-mail leon schumacher@muccmail.missouri.edu.

Papers:

Frisby, J.C. and L.G. Schumacher (1992). Biodiesel Fuel. M.U. Guide G1990. 


\section{Project Title:}

Use of Seed-Based Lubricants as a Replacement for Petroleum Oil

Background: AARC, a wholly owned govemment corporation of USDA, is a venture capital firm that makes investments in companies to help commercialize bio-based industrial products (non-food, non-feed) from agricultural, forestry materials, and animal by-products. AARC has assisted a company, Agro Management Group, Incorporated.

Objective: To test the uses of seed-based lubricants, such as canola-based oils, in small engines and in automobiles as a complete replacement for petroleum-derived oils.

Status: Ongoing development effort.

\section{Accomplishments:}

- BIO 25/30, is a new crankcase oil, which has been designed to operate in four-cycle engines such as lawn mowers, pumps, generators, and automobiles.

- Results of preliminary testing show reduced engine operating temperature, reduced oil consumption, and reduced engine wear compared to conventional petroleum oils. The use of this product would reduce the environmental hazard associated with the disposal of waste petroleum.

- A small engine manufacturer, Briggs and Stratton, is cooperating with Agro Management to test the use of the canola-based oils in its small engines.

Participants: Agro Management Group, Inc.

Sponsoring Organization(s): Alternative Agricultural Research and Commercialization Corporation, U.S. Department of Agriculture

Point of Contact: Ron Buckhalt, U.S. Department of Agriculture/AARC, 14th and Independence Avenue, S.W., Room 0156, South Building, Washington, D.C. 20250-0400, phone 202.690.1633; Jim Lambert, Agro Management Group, Inc., 1127 W. Colorado Avenue, Colorado Springs, CO 80904, phone 719.520.9931.

\section{Papers:}

Source Book 1997. Altemative Agricultural Research and Commercialization Corporation.

Additional Information:

AARC Home Page: http://www.usda.gov/aarc. 


\section{Stability \& Storage}

Also see the following projects:

Transportation and Handling of Biodiesel and Biodiesel Blends

Materials Compatibility, Fuel Blend Characteristics, Engine Dynamometer Evaluation

Third Workshop: Commercialization of Biodiesel: Producing a Quality Fuel 


\section{Project Title:}

Biodiesel Blends in lowa Underground Storage Tanks

Background: In order to be able to provide a supply of biodiesel for IDOT vehicles, it must be determined that biodiesel is viable option for fuel and that storage of biodiesel is not a problem.

\section{Objectives:}

- The biodiesel will be tested after storage to determine whether there have been any detrimental effects to the fuel quality.

- Tests will be performed periodically to evaluate biodiesel's storage durability.

- The project will determined the best location for biodiesel storage and handling.

Status: November 1996-November 1997.

\section{Accomplishments:}

- Nineteen locations have USTs storing biodiesel for evaluation in state owned facilities at a $5 \%$ biodiesel blend.

- The fuel was made available for use in IDOT vehicles and shops.

Participants: lowa Department of Transportation

Sponsoring Organization(s): The State of lowa and lowa Department of Transportation

Point of Contact: Kevon Jones, IDOT, 800 Lincoln Way Ames, IA 50010, phone 515.239.1670, fax 515.239.1658

Paper: None available at this time, but one is expected once the project is complete. 
Project Title:

City of Boston, Massachusetts Garage Retrofit with Biodiesel Tanks

Background: The project was designed to determine how buses fueled by biodiesel operate and evaluate biodiesel and biodiesel blends storage stability during the course of a year.

Objectives:

- Provide evidence that biodiesel can be stored with diesel and operate with diesel fuel; and the study itself aims to show the ease of the conversion process and blending.

- Provide an example of how to effectively retrofit tanks with biodiesel and how storage affects the biodiesel fuel.

Status: Ongoing

Accomplishments:

- The SATA retrofitted its garages with storage tanks.

- The MBTA brought in biodiesel fuel tanks for two garages.

Participants: City of Boston, Massachusetts Bay Transit Authority, State Agency Transit Authority

Sponsoring Organization(s): Massachusetts Bay Transit Authority, State Agency Transit Authority

Point of Contact: Andrew Brennen, State Agency Transit Authority, phone 617.222.3126 Irving Sacks, Division of Energy Resources, 100 Cambridge Street, 15th Floor Boston, MA 02202, phone 617.727.4732, ext. 131, fax 617.727.0030.

Paper: None available at this time. 


\section{Project Title:}

\section{Long Term Storage}

Background: The stability of biodiesel during extended periods is relatively undocumented. This project was crafted to better understand the fuel shelf life.

\section{Objectives:}

- Determine the stability of biodiesel and biodiesel/petrodiesel blends over an extended storage period with differing petrodiesels.

- Evaluate the efficacy of stabilizing additives in extending their storage life.

- Evaluate the impasse of the presence of various metals.

Status: Project is due for completion in December 1997.

Accomplishments: Selection of the additives, metals, and petrodiesels has been accomplished and the testing is now complete. A final report is pending review.

Participants: BDM and NIPER

Sponsoring Organization(s): Illinois Soybean Checkoff Board and NBB

Point of Contact: Ms. Bev Thessen, National Biodiesel Board, P.O. Box 104898, Jefferson City, MO, 65110-4898, phone 573.635.3893, fax 573.635.7913, e-mail biodiesel@ sockets.net.

Paper: None available at this time. 


\section{Project Title:}

Thermal and Oxidative Stability

Background: The oxidation and thermal stability of conventional petroleum diesel is being investigated as a potential source of storage, fuel system, and engine problems. The recent introduction of low-sulfur diesel fuel is believed to exacerbate the situation. This project is designed to quantify the oxidation and thermal stability of biodiesel and biodiesel blends using SAE or ASTM approved procedures and to determine whether these tests will present an accurate description of biodiesel's performance in the field.

\section{Objectives:}

- Quantify the oxidation and thermal stability of biodiesel and biodiesel blends with petroleum based diesel fuels using the SAE and/or ASTM procedures.

- Evaluate the effectiveness of several stability enhancing additive combinations.

- Determine the likely validity of the petroleum-based analytical procedures in predicting biodiesel performance.

Status: August 1, 1995-March 31, 1997

\section{Accomplishments:}

- This project investigated several facets of biodiesel stability and presented a summary of past research concerning diesel fuels stability.

- The results of this project provide information regarding which instruments can be used to further evaluate the stability of biodiesel and additive efficacies.

- Biodiesel oxidized faster than petrodiesel but did not form color bodies associated with diesel fuel oxidation. Biodiesel also formed slightly more sediment over time in storage than the petrodiesel used for the testing.

- The efficacies of petroleum additives and a food-grade stabilizer yielded the most reduction of sediment over time in storage.

- Further research is needed on the testing methods when analyzing biodiesel stability and their correlation to field performance.

Participants: National Biodiesel Board and System Lab Services, a Williams Pipeline Company

Sponsoring Organization(s): National Biodiesel Board and United Soybean Board

Point of Contact: Ms. Bev Thessen, National Biodiesel Board, P.O. Box 104898, Jefferson City, MO, 65110-4898, phone 573.635.3893, fax 573.635.7913, e-mail biodiesel@sockets.net.

\section{Paper:}

Thermal and Oxidative Stability of Biodiesel, National Biodiesel Board, Jefferson City, MO 


\section{Project Title:}

Two-Year Storage Study with Methyl and Ethyl Esters of Rapeseed

Background: Biodiesel is gaining recognition as a renewable altemative to diesel fuel. One step to realizing commercial biodiesel is how well it stores and what effect storing for long periods has on the performance of the fuel. The problems of fuel deterioration with biodiesel during storage are more severe than for commercial diesel fuel. Although vegetable oils contain natural antioxidants, their high degree of unsaturation makes them susceptible to gum formation. Because fuel deterioration occurs mainly by oxidative polymerization, leading to gum formations, one purpose of this study was to determine the rate of oxidative polymerization for different fatty acid esters prepared from rapeseed, as affected by container types, and environments. Another purpose of this study was to use short-term engine coking and torque test procedure to determine whether the presence of the oxidation products affected the engine performance.

\section{Objectives:}

- Produce RME and REE and characterize their properties according to ASAE EP552.

- Store triplicate sets of vented glass and vented steel containers of RME and REE in flammable solvent storage cabinets at inside and outside ambient temperatures.

- Analyze fuel properties from each storage container every 3 months for a 24-month period and compare with the initial values.

- Compare 2-year stored RME and REE in short-term engine performance tests with new RME, REE, and diesel fuel.

\section{Status: Completed}

Accomplishments:

- No effect was found for container type; test values compare very close for metal and glass containers.

- For both fuels the peroxide and acid values, density, and viscosity tended to increase over time. The heat of combustion, on the other hand, tended to decrease slightly over time.

- The short-term engine tests, including torque, power, fuel economy, and coking tests showed very small amounts of change between the stored fuels and the new fuels.

Participants: University of Idaho

Sponsoring Organization(s): University of Idaho

Point of Contact: J.C. Thompson, Engineering Technician, Department of Biological and Agricultural Engineering, University of Idaho, Moscow, ID 83844-2060.

Paper(s):

Thompson, J. C.; Peterson, C. L.; Reece, D. L.; Beck, S.M. (1996) "Two Year Storage Study with Methyl and Ethyl Esters of Rapeseed" Proceedings of the Third Liquid Fuels Conference, September 15-17, Nashville, TN. Liquid Fuels and Industrial Products from Renewable Resources, pp. 104-114. 


\section{E. Biodegradation \& Toxicity}

\section{Also see the following projects:}

Alternative Fuels and Lubricants from Rapeseed

Ethyl Ester Process Scale-Up and Biodegradability of Biodiesel

Expanded Rapeseed Ethyl Ester (REE) Demonstration and Testing, and Cooperative Development of Hydrogenated Soy Ethyl Ester (HySEE) Biodiesel

Rapeseed Oil as a Fuel for Agriculture

Second Workshop: Commercialization of Biodiesel, Environmental and Health Benefits 


\section{Project Title:}

Acute Dermal Toxicity Study of $100 \%$ RME in Albino Rabbits

Background: All motor fuels and chemicals that have exposure to the general public must undergo considerable safety and handling tests. This project was one of many tests and evaluations necessary for biodiesel to pass stringent federal standards.

\section{Objectives:}

- To determine the median lethal dose, evaluate potential systemic toxicity, and evaluate the local irritation of the test material when applied to the skin of albino rabbits.

- The project involved testing on five males and five females between 2309 and 2598 grams of biodiesel ointment.

Status: January 1996

Accomplishments:

- There were no deaths, test material-related clinical findings, body weight changes, or gross necropsy findings.

- The $2,000 \mathrm{mg} / \mathrm{kg}$ dose level was found to be a "no observable effect level" for systemic toxicity under the conditions of this study.

Participants: University of Idaho, Agricultural Engineering Department, WIL Research Laboratories, Inc.

Sponsoring Organization(s): University of Idaho, Agricultural Engineering Department

Point of Contact: Bennett Varsho, WIL Research Laboratories, Inc.; 1407 George Road, Ashland OH 44805-9281, phone 419.289.8700, fax 419.289.3650.

Paper:

Varsho, B.J. (1996). Acute Dermal Toxicity Study of 100\% RME in Albino Rabbits. WIL 275008. Ashland, OH: WIL Research Laboratories, Inc. 


\section{Project Title:}

Biodegradability and Toxicity of Biodiesel Fuels

Background: The primary goals of this program are the thorough documentation of the biodegradability and toxicity of a number of biodiesel fuels and blends.

\section{Objectives:}

- Determine the biodegradability of RME, ethyl soyate, NR, and diesel fuel.

- Investigate the co-metabolism of REE and methyl soyate to improve the biodegradability of diesel fuel spill.

- Coordinate toxicology studies for methyl soyate and RME, specifically exposing fathead minnows to REE.

- Develop a process for REE comparable to RME and (a) improve the percentage that is transesterified; (b) improve the PP; and (c) complete a 2-year storability study.

Status: Project completed.

Accomplishments: Will be detailed in final project report.

Participants: University of Idaho, U.S. Department of Agriculture-Cooperative State Research, Education, and Extension Service

Sponsoring Organization(s): U.S. Department of Agriculture-Cooperative State Research, Education, and Extension Service

Point of Contact: Charles L. Peterson, Department of Agricultural Engineering, University of Idaho, Moscow, ID 83844; phone 208.885.7906, fax 208.885.8923, e-mail peterson @ novell.uidaho.edu.

Papers: None available at this time. 


\section{Project Title:}

Biodegradability of Biodiesel in the Aquatic Environment

Background: As biodiesel fuels are becoming commercialized, their fate in the environment is an area of concem because petroleum spills constitute a major source of contamination of the ecosystem. Among these concerns, water quality is one of the most important issues for living systems. Although biodiesel consists of mainly fatty acids, it is not desirable if it accumulates in the waterways. Grease makes up to $23 \%-52 \%$ of the total organic fraction in sewage. Therefore, it is important to examine the biodegradability of biodiesel fuels and their biodegradation rates in natural waterways in case they enter the aquatic environment in the course of their use or disposal.

\section{Objectives:}

- Examine the biodegradation pattem in the REE/diesel blend.

- Test the biodegradability of various biodiesel fuels and diesel fuel.

- Investigate the biodegradation rates for REE and compare them with those for the diesel in the aquatic environment by carbon dioxide evolution method and calibrated the results by GC analysis.

Status: June 1995

\section{Accomplishments:}

- All the biodiesel fuels are "readily biodegradable" compounds according to EPA standards and have a relatively high biodegradation rate in the aquatic environment

- Biodiesel can promote and speed up the biodegradation of diesel. The more biodiesel present in a biodiesel/diesel mixture, the faster the degradation rate.

- The mineralization rate for a compound determined from $\mathrm{CO}_{2}$ evolution is much slower than its primary degradation rate from $\mathrm{GC}$, but the results have good correlation. It is possible to use the $\mathrm{CO}_{2}$ evolution method to estimate the biodegradation rate for an organic compound and it is economical and environmentally safe.

Participants: University of Idaho

Sponsoring Organization(s): U.S. Department of Agriculture-Cooperative State Research, Education, and Extension Service

Point of Contact: Dr. Charles Peterson, Department of Agricultural Engineering, University of Idaho, Moscow, Idaho 83844, phone 208.885.7906, fax 208.885.8923, e-mail peterson@novell.uidaho.edu.

\section{Paper(s):}

Zhang, X.; Peterson, C.L.; Reece, D.; Moller, G.; Haws, R. (1995). "Biodegradability of Biodiesel in the Aquatic Environment." ASAE Annual Intemation Meeting; June 18-23, Chicago, IL. ASAE 956742. St. Joseph, Ml: American Society of Automotive Engineers, pp. 1-14. 


\section{Project Title:}

\section{Biodegradation of Synthetic Diesel}

Background: This program involves the extension of methodologies for evaluating oil spill protocols for conventional petroleum products to the special case of biodiesel. The biodiesel and biodiesel blends will be tested under oxic and anoxic conditions in three environments: marine, freshwater, and soil microcosms. The disappearance of the biodiesel materials will be monitored using protocols previously developed for determining the effects of bioremediation agents on petroleum products. The rates of degradation will followed by loss of target compounds and by following oxygen uptake and/or by carbon dioxide evolution. GC/MS will be used to measure material decomposition.

\section{Objectives:}

- Develop a methodology to evaluate the biodegradability of biodiesel materials in oil spill environments.

- Determine biodegradability under varying environmental conditions of microcosms, e.g., aerobic and anaerobic.

- Develop methodologies to assess the biodegradability of biodiesel.

- Characterize marine and sulfate-reducing bacterial isolates that degrade biodiesel.

- Screen new bacterial isolates for the degradation of both biodiesel and petroleum diesel.

- Determine biological and chemical dynamics for biodiesel blends.

- Investigate biodiesel degradation and biodiversity in storage tanks.

Status: September 1993-August 1996.

\section{Accomplishments:}

- Completed the characterization of the aerobic and anaerobic biodiesel degrading species isolated from fresh water.

- Tested sulfur compounds (e.g., sulfate, sulfite, and thiosulfate) as alternative electron acceptors for anaerobic degradation.

- Began studies on the characterization of the biodegradation pathway and initiated studies on dynamics of biodiesel blends.

- Tested sulfate, thiosulfate, and sulfite as altemative electron acceptors in the anaerobic degradation of biodiesel.

- It appears that sulfate, sulfite, or thiosulfate cannot be used as a terminal electron acceptor when well-aerated freshwater samples were used as inoculum.

- Sulfate and biodiesel did support growth when anoxic samples were used as inoculum and cautions were taken not to aerate the sample.

Participants: Duquesne University

Sponsoring Organization(s): U.S. Department of Agriculture-Cooperative State Research, Education, and Extension Service

Point of Contact: John Stolz, Department of Biological Sciences, Duquesne University, Pittsburgh, PA 15282, phone 412.396.6333.

Papers: 
Buzzell, J. and J.F. Stolz (1995). "Pseudomonas Oleovorans Is a Gamma Proteobacterium." Int, J. System. Bac. (under revision).

Follis, Paige, J. Buzzell, G. Floro, R. Donofrio, W. M. Griffin, and J. F. Stolz (1995). "Aerobic and Anaerobic Biodegradation of the Methyl Esterified Fatty Acids of Soy Diesel in Freshwater and Soil Environments." Appl. Environ. Microbiol.

Additional Information: CRIS Accession No.: 9163215 


\section{Project Title:}

Toxicity of Particulate and Semi-Volatile Emissions from SME and Biodiesel Blended Fuels

Background: One group of toxicologically important compounds that may be present in diesel, and potentially in biodiesel exhaust emissions, are PAHs and their substitute derivatives nPAHs. Some PAH and nPAHs are potent mutagens and carcinogens in laboratory animals and in humans. This research may be very timely as the current suit against Califomia refineries and trucking associations progress, which charges that diesel exhaust emissions are a health hazard. Previous research on RME and REE indicates that biodiesel may reduce the toxic nature of petroleum exhaust. NREL took advantage of several ongoing engine tests to collect data for this project.

- $\quad$ CIFER portion of the project: This project takes advantage of ongoing research under the Multi-Feedstock Biodiesel Project, by placing a separate subcontract with CIFER to perform additional research. This project is designed to add funds to CIFER to perform the additional emissions analysis. Specifically, this project requires CIFER to include cold transient tests, $\mathrm{C} 1-\mathrm{C} 12$ and aldehyde speciation, and additional particulate sample collection for bioassay analysis while conducting research to support the MultiFeedstock Biodiesel Project. All biodiesel tested in this portion of the project are $20 \%$ biodiesel and $80 \%$ test diesel blends.

- NBB and Caterpillar portion of the project: NBB is working cooperatively with Caterpillar to collect emission data from a $3406 \mathrm{D}$ test engine at Caterpillar's Peoria, IL laboratory. NREL will support the the University of Califomia-Davis staff time and expenses necessary to collect sufficient quantities of particulate and SOF emissions for bioassay analysis. NBB and Caterpillar will be collecting speciated emission data (PAH, nPAH) to support health effects research. Only neat SME is tested in this part of the test.

- University of California-Davis: UCD will conduct chemical analyses on the particulate and vapor emissions from SME from the Caterpillar testing as well as conduct bioassay tests to determine the mutagenic potential of the particular emissions. USDA will also conduct bioassay analyses on the biodiesel blends used in the Multi-Feedstock project, which include: yellow grease, tallow, lard, soy, and acidulated soapstocks.

Objective: To develop a body of data for submission to EPA that describes the chemical and biological characteristics of vapor- and solid-phase particulate emissions to support the registration of biodiesel under 40 CFR 79, Section 211 (f) "Registration of Fuels and Fuel Additives."

Status: The project has just been initiated and will run through September 1998.

\section{Accomplishments:}

NBB and Caterpillar project:

- The testing was completed on two Cummins 1988 L10 engines joined in tandem. The test runs for $125 \mathrm{~h}$ on a cycle that alternates between driving and motoring of each engine. The pass/fail criteria for this test are based on carbon and lacquer deposits (CRC) rating) on the injector plunger, as well as loss specification of the complete injector.

- Based on the results from the Cummins L10 Injector Deposit Test, the use of $20 \%$ biodiesel blended with various petrodiesel fuels increases injector deposits. However, adding commercially available detergency additive can reduce the deposit formation to the 
equivalent level experienced with neat petrodiesel. Further testing is required to procure an additive that can be blended with the petrodiesel and biodiesel mixture to reduce deposits levels to within the passing range on the L10 Injector Deposit Test.

Participants: Colorado Institute for Fuels and Engine Research, Colorado School of Mines, National Renewable Energy Laboratory, University of Califomia-Davis; and MARC-IV Consulting, Inc.

Sponsoring Organization(s): U.S. Department of Energy Office of Fuels Development, Caterpillar Inc.

Point of Contact: Dr. K. Shaine Tyson, National Renewable Energy Laboratory, 1617 Cole Blvd., Golden, CO 80401, phone 303.275.4616, fax 303.275.4675, e-mail tysonk@tcplink.nrel.gov.

\section{Papers:}

"Health-Related Emissions from Various Biodiesel Blends in a DDC Series 60 Engine," forthcoming.

"Bioassay Analysis of Biodiesel Produced from Low Value Feedstocks," forthcoming.

"Chemical and Bioassay Analysis of SME PM Emissions from a Caterpillar 3406/435 HP," forthcoming. 


\section{Engine Data}

\section{Also see the following projects:}

Multifeedstock Biodiesel Project

Technology for Efficient Use of Agricultural Resources 


\section{Project Title:}

2-Cycle Engine 200 Hour EMA Test with Hydrogenated Soy Ethyl Ester (HySEE)

Background: In adding to the body of literature on biodiesel performance, this study was undertaken to develop data on 2-cycle engine use of HySEE as a lubricant.

Objectives: The objective of this project was to determine whether the bio-lubricant HySEE could be used in small two-cycle engines. The University of Idaho conducted the $200-h$ Engine Manufacturers Association engine test.

Status: Project completed December 31, 1995

Accomplishments: Six fuels were evaluated and a final report was produced.

Participants: University of Idaho

Sponsoring Organization(s): Pacific Northwest and Alaska Regional Biomass Energy Program

Point of Contact: Dr. Charles L. Peterson, Department of Agricultural Engineering, University of Idaho, Moscow, Idaho 83844; phone208.885.7906, fax 208.885.8923, e-mail peterson@novell.uidaho.edu.

\section{Papers:}

Screening Test for Rape Ethyl Ester 2-Cycle Oils. February 15, 1996. 


\section{Project Title:}

Alternative Fuels and Lubricants from Rapeseed

Background: Production, processing, engine testing, and fuel properties will be used to determine application of rapeseed as a potential engine fuel.

\section{Objectives:}

- Determine problems associated with the use of RME in commercial use such as material compatibility, storage life, handling problems, and low-temperature operation in on-road and off-road vehicles.

- Develop a process of REE comparable to RME.

- Determine performance, durability, and possible engine modifications for optimizing efficiency of engines fueled with both REE and RME.

- Determine the performance of the RME and REE fuels in engine injector coking tests, EMA engine test evaluation cycles, and long-term endurance tests.

- Investigate biodegradability, emissions, and other environmental advantages of RME and REE in comparison to No. 2 diesel fuel.

- Develop criteria for RME and REE fuel standards and standard test procedures, which can be used to ensure manufacturers of a consistent quality of rape oil-based fuels.

- Investigate the potential of biodegradable, rape oil-based lubricants and hydraulic oils.

Status: Project initiated in January 1994 and is scheduled to be completed by January 1998.

\section{Accomplishments:}

- The on-farm biodiesel plant expressed $22,500 \mathrm{~kg}$ of rapeseed in 1996 resulting in $9,710 \mathrm{~L}$ of oil. More than 18,900 L of biodiesel, all but 2,000 L with ethanol, was produced, of which 6,358 $\mathrm{L}$ was from used oil and 6,124 $\mathrm{L}$ for our joint project with Yellowstone Park. Biodiesel produced from the used hydrogenated soy oil is usable as a fuel but has a high $P P$, making it a challenge for use in cold weather.

- Tests are continuing with three of the on-road vehicles; the 1992 Ford has reached 76,985 miles, the 1994 Dodge 56,852 miles, the 1995 Dodge about 60,000 miles and the 1992 diesel vehicle operated by IDWR, completed the 100,000-mile milestone. Cummins Engine Co. evaluated the engine which showed less deposits and the engine which showed less deposits and wear than a similar engine operated on diesel. Two items showed some distress. The front and rear oil seals were hardened slightly. Vamish was apparent in the injector pump.

- Acute oral toxicity limit tests showed that RME and REE (biodiesel) had LD50 values greater than $5,000 \mathrm{mg} / \mathrm{kg}$ when administered once orally to albino rats and acute dermal toxicity tests showed LD50 values greater than $2,000 \mathrm{mg} / \mathrm{kg}$ when administered once to the clipped, intact skin of albino rabbits. The biodegradability and biodegradation rates of several biodiesel fuels in the aquatic environment show that all biodiesel fuels are readily biodegradable. After 28 days, all biodiesel fuels were within the range: $77 \%-89 \%$ biodegraded; diesel fuel was only $18 \%$ biodegraded.

Participants: Department of Biological and Agricultural Engineering, University of Idaho Sponsoring Organization(s): U.S. Department of Agriculture-Cooperative State Research, Education, and Extension Service 
Point of Contact: Dr. Charles L. Peterson, Department of Agricultural Engineering, University of Idaho, Moscow, ID 83844, phone 208.885.7906, fax 208.885.8923, e-mail

peterson@ novell.uidaho.edu

\section{Papers:}

Hammond, B.L. (1996). "Performance and Durability Testing of Diesel Engines Using

Ethyl/Methyl Ester Fuels." An unpublished MS thesis, Dept. of Biol. and Agr. Engr., University of Idaho, Moscow, ID.

Peterson, C.L. and D.L. Reece (1996). "Emissions Characteristics of Ethyl and Methyl Ester of Rapeseed Oil Compared with Low Sulfur Diesel Control Fuel in a Chassis Dynamometer Test of a Pickup Truck." Trans. of the ASAE 39(3)-805-816.

Peterson, C.L., D.L. Reece, J.C. Thompson, S.M. Beck and C. Chase (1996). "Ethyl Ester of Rapeseed Used as a Biodiesel Fuel - A Case Study." Biomass and Bioenergy 10(5/6):331336.

Peterson, C.L., D.L. Reece, B.L. Hammond, J.C. Thompson and S.M. Beck (1997). "Processing, Characterization and Performance of Eight Fuels from Lipids." Applied Engr. in Agr. 13(l):71-79.

Peterson, C.L. and D.L. Reece (1996). "Emissions Testing with Blends of Esters of Rapeseed Oil Fuel with and without a Catalytic Converter." SAE Paper No. 961114. SAE, Warrendale, PA.

Peterson, C. L.; Hammond, B. L.; Reece, D. L. (1996) "Engine Performance and Emissions with Methyl and Ethyl Esters of Rapeseed Oil." Proceedings of the Third Liquid Fuels Conference, September 15-17, Nashville, TN. Liquid Fuels and Industrial Products from Renewable Resources, pp.116-127.

Thompson, J. C.; Peterson, C. L.; Reece, D. L.; Beck, S.M. (1996) "Two Year Storage Study with Methyl and Ethyl Esters of Rapeseed" Proceedings of the Third Liquid Fuels Conference, September 15-17, Nashville, TN. Liquid Fuels and Industrial Products from Renewable Resources, pp.104-114.

Additional Information: CRIS Accession No.: 9164150 
Project Title:

Identification of Chemical Changes Occurring during the Transient Injection of Selected Vegetable Oils

Background: A number of engine experiments indicate that vegetable oils used as fuels for diesel engines create durability problems in many of these engines. The direct durability problems include nozzle coking, engine deposits, and lube oil dilution. The indirect problems include ring sticking, scuffing of the cylinder liners, injection nozzle failure, and lubricant failure due to polymerization of the vegetable oil. Most experience indicates that the durability problems are more severe in direct-injection engines than in the indirect-injection engines.

\section{Objectives:}

- Determine whether the vegetable oils change chemically during the diesel type of injection into a high-temperature, high-pressure environment of nitrogen.

- Determine the nature of the chemical changes, if detectable, and identify any new compounds formed during the process.

Status: 1993

\section{Accomplishments:}

- Major changes in the chemical makeup of vegetable oils occur during injection. These consist of fractures of the large molecules and the formation of lower molecular weight compounds.

- The IR analyses indicate the presence or formation of free carboxylic acid, trans-olefins, cis-olefins and terminal olefins.

- The analyses of the transesterified and esterified samples indicate that the polyunsaturated fatty acids are most affected by the injection process. It appears that the lower molecular weight materials result from breakdown of the linoleic and linoenic acids.

- The chemical changes that occur during the injection process could account for the unexpected spray characteristics of the vegetable oils.

Participants: Southwest Research Institute

Sponsoring Organization(s): U.S. Department of Agriculture

Point of Contact: Thomas W. Ryan III, Southwest Research Institute, 6220 Culebra Road, San Antonio, TX 78238-5100, phone 210.684.5111, fax 210.522.3496.

\section{Paper(s):}

Ryan, T.W.; Bagby, M.O. (1993). "Identification of Chemical Changes Occurring during the Transient Injection of Selected Vegetable Oils." New Developments in Altemative Fuels and Gasolines for SI and CI Engines (SP-958), March 1-5, Detroit, MI. SAE \# 930933.

Warrendale, PA: Society of Automotive Engineers, pp. 201-210. 


\section{Project Title:}

Industrial Agricultural Products Center

Background: This is a broad-based project with a component on biodiesel research.

Research activity includes in the areas of starch-based plastic foams, plant protein films, and tallow and soybean oil processing and use as biodiesel. Industrial uses of beef tallow are being assessed along with processing technologies, ester properties, and biodiesel emissions and engine performance.

\section{Objectives:}

- Identify niche markets for industrial use of agricultural-based products.

- Improve and develop conversion processes as needed for specific product isolation and use.

- Provide technical, marketing, and business assistance to industries.

- Coordinate agricultural industrial materials research at the University of Nebraska-Lincoln.

Status: Project initiated in July 1993 and is scheduled to be completed by September 1998.

Accomplishments:

- A Cummins N14-410 engine was operated on 12 fuels produced by blending methyl tallowate, methyl soyate, and fuel ethanol with No. 2 diesel fuel. Peak rates of heat release for all fuels were less than for No. 2 diesel fuel. When methyl tallowate was blended with No. 2 diesel fuel, the shift in the location of peak heat release was away from TDC, whereas the addition of ethanol to the blend shifted the location toward TDC. Ignition delay slightly decreased when methyl tallowate was blended with diesel fuel. However, ignition delays were not affected by the methyl tallowate or ethanol contents of the blends. The charge temperature decreased with decrease in diesel content of fuel blends. The indicated mean effective pressure and maximum rate of pressure rise values for all fuel blends were less than for diesel fuel.

- It was concluded that the fuel blends used in this study would have no detrimental longterm effects on engine performance, wear, and knock. Mixtures of starch (25\% amylase), ethylene glycol, and concentrated sulfuric acid were extruded in a Brabender laboratory conical-twin-screw extruder with postextruder reactor modifications. Temperature, ethylene glycol-starch mole ratio, and screw speed were permuted to enhance the yield of glycosides. Optimum process conditions of $160^{\circ} \mathrm{C}, 20$-rpm screw speed, and mole ratio of 3 with a static mix and cooler gave $91 \%$ yield of glycosides.

Participants: Industrial Agricultural Products Center, University of Nebraska

Sponsoring Organization(s): U.S. Department of Agriculture-Cooperative State Research, Education, and Extension Service

Point of Contact: Milford Hanna, Director, Industrial Agricultural Products Center, $211 \mathrm{LW}$ Chase Hall, University of Nebraska-Lincoln, Lincoln, NE 68583-0730, phone 402.472.1624.

\section{Papers:}


Ali, Y. and Hanna, M.A. (1997) . "In-cylinder pressure characteristics of a D.I. heavy-duty diesel engine on biodiesel fuel." SAE Technical Paper Series 971683. State of Altemative Fuel Technologies--1997, pp. 143-151. SAE Intemational, Warrendale, PA.

Ali, Y. and M.A. Hanna (1996). "Durability testing of diesel fuel, methyl tallowate and ethanol blend in Cummins N14-410 engine." Trans. of the ASAE. 39 (3): 793-797.

Ali, Y., M.A. Hanna, and J.E. Borg (1996). "Effect of altemative diesel fuels on heat release curves for Cummins N14-410 diesel engine." Trans. of the ASAE. 39 (2): 407-414.

Ali, Y., M.A. Hanna, and J.E. Borg (1996). "In-cylinder pressure characteristics of a $\mathrm{Cl}$ engine using blends of diesel fuel; and methyl esters of beef tallow." Trans. of the ASAE 39( ):799804.

Ali, Y., M.A. Hanna (1996). Durability testing of diesel fuel, methyl tallowate and ethanol blend in.

Ali, Y., M.A. Hanna, J.E. Borg (1996). Effect of altemative diesel fuels on heat release curves fo.

Ali, Y., M.A. Hanna, J.E. Borg (1996). In-cylinder pressure characteristics of a Cl engine using bl.

Bhatnagar, S. and M.A. Hanna (1996). Effect of Talc on Properties of Com Starch Extrudates. Starke. 48.

Ghorpade, V.M. and M.A. Hanna (1996). Mechanical Properties of Soy Protein-Polyethylene Ribbon and Film.

Ryu, D., S.K. Katta, L. Bullerman, M.A. Hanna, and A. Gennadios (1996). Microbial Stability of Methyl.

Subramanian, K. and M.A. Hanna (1996). Glycol glycosides synthesis by reactive extrusion with a stat.

Additional Information: CRIS Accession No.: 9161844 


\section{Project Title:}

Monitor Biodiesel Use in Selected Tactical Vehicles at Yuma, Arizona

Background: A biodiesel fuel evaluation was performed on various U.S. Army tactical wheeled vehicles from March 1994 through March 1995 at the U.S. Army Yuma Proving Ground. Testing was conducted to compare vehicle system performance when the vehicles were operated with a $80 \% / 20 \% \mathrm{JP}-8 /$ biodiesel fuel blend instead of neat (or $100 \%$ ) JP-8 fuel. The vehicle types under test included the Commercial Utility Cargo Vehicle, High Mobility Multipurpose Wheeled Vehicle, M939A2 Series of 5-Ton Truck, Heavy Expanded Mobility Tactical Truck and the M915A2 Truck-Tractor.

Objective: To collect data and evaluate the relative performance of a $80 / 20 \mathrm{JP}-8 / \mathrm{biodiesel}$ blend fuel mixture compared to neat-JP-8 and DF-2 fuels in different wheeled vehicle systems.

Status: Program was funded in FY 1993 and completed in FY 1995.

Accomplishments:

- Preliminary vehicle testing at Yuma Proving Ground has been completed.

- Research found that biodiesel in a $20 \%$ blend with JP-8 reduces emissions and enhances acceleration.

Participants: U.S. Army Tank - Automotive and Armaments Command

Sponsoring Organization(s): U.S. Department of Agriculture-Cooperative State Research, Education, and Extension Service

Point of Contact: Carmela Bailey, USDA-CSREES, 910 D. Street, SW, Aerospace Bldg. 8th Floor, Washington DC, phone 202.401.6443

\section{Papers:}

Lucas, W. Materiel Test Directorate. U.S. Army Yuma Proving Ground, Yuma, Arizona.

"Summary Test Report for the Biodiesel Fuel Evaluation for the U.S. Army Tactical Wheeled Vehicles, Volume I of Series." Prepared for the U.S. Amy Tank-Automotive and Amaments Command, Warren, Ml and U.S. Amy Test and Evaluation Command, Aberdeen Proving Ground, MD. May 1995. TECOM Project No. 1-EG-095-000-028. 
Project Title:

Power, Emissions, and Bioresponse of Biodiesel in a Marine Environment

Background: The use of biodiesel in an unmodified, commercially available marine diesel engine was tested under dynamometer-controlled load conditions.

Objective: To contrast engine performance and potential effect on the environment when the engine was fueled with $100 \%$ SME (biodiesel) versus 100 No. 2 petroleum diesel (petrodiesel).

Status: Completed

Accomplishments:

- The four-cylinder, turbocharged, intercooled direct-injection diesel engine produced from $2 \%$ to $7 \%$ less power when fueled with biodiesel.

- The production of CO was significantly reduced and soot was reduced by using biodiesel.

- Biodiesel produced greater power than petrodiesel when the engine was operated at full throttle at speeds less than $2650 \mathrm{rpm}$.

- Dosed water with biodiesel exhaust at $50 \%$ engine load setting resulted in "no-detect" in PAHs.

Participants: University of Tennessee

Sponsoring Organization(s): NBB, Tennessee Agricultural Experiment Station, and VolvoPenta

Point of Contact: Ms. Bev Thessen, National Biodiesel Board, P.O. Box 104898, Jefferson City, MO, 65110-4898, phone 573.635.3893, fax 573.635.7913, e-mail biodiesel@ sockets.net.

Paper(s):

Womac, A. R.; Stange, R, J.; Crouch, J. A.; Easterly, C. (1996) “Power Emissions, and Bioresponse of Biodiesel in a Marine Environment". Proceedings of the Third Liquid Fuels Conference, September 15-17, Nashville, TN. Liquid Fuels and Industrial Products from Renewable Resources, pp.177-190. 


\section{A. Emissions}

\section{Also see the following projects:}

Biodiesel Fuels--Vegetable Oil/Alcohol Blends

Biomass-Derived Alternatives in High Performance Snowmobile Engines: A Snowmobile in the Park

Bi-State Development Agency Alternative Fuel Bus Testing of 10 Buses

Clean Air Partners--Biodiesel Water Shuttles at Logan Airport

Demonstrate and Promote Biodiesel as a Transportation Fuel

Demonstrate Biodiesel in Commuter Trains and Buses

Developing Yellow Mustard (Sinapis Alba L.) Cultivators Suitable for Biodiesel Production in the United States

Development of Rapeseed Biodiesel for Use in High-Speed Diesel Engines

Expanded Rapeseed Ethyl Ester (REE) Demonstration and Testing, and Cooperative Development of Hydrogenated Soy Ethyl Ester (HySEE) Biodiesel

Over-the-Road Heavy-Duty Diesel Engine Operational Demonstration

Rapeseed Oil as a Fuel for Agriculture

Second Workshop: Commercialization of Biodiesel, Environmental and Health Benefits

Twin Cities, Minnesota Biodiesel Pickup Truck Demonstration

Use of Vegetable Oil as Fuel for Compression Ignition, Intemal Combustion Engines 


\section{Project Title:}

\section{Agricultural and Rural Transportation Systems}

Background: There is a small component on biodiesel in this project although the project's main focus is on examining structural changes in the U.S. grain transportation and marketing infrastructure.

Objective: The project's objective related to biodiesel was to evaluate the practicality and economic potential for using biodiesel fuelsto reduce particulate levels in mines to meet new EPA and OSHA standards.

Status: Project initiated in October 1994 and scheduled to be completed by September 1997.

\section{Accomplishments:}

- Completed joint project with the University of Minnesota Center for Biodiesel Research evaluating the practicality and economic potential for using biodiesel fuels to reduce particulate levels in mines to meet new EPA and OSHA standards. Blends of $0 \%, 30 \%$, $70 \%$, and $100 \%$ biodiesel and regular diesel were compared to systems using catalytic converters and/or filters for lifetime net present value and annual variable costs to meet various PM levels in two model mines.

- Although technically feasible, we found that at current levels of more than $\$ 3.00 / \mathrm{gal}$, biodiesel fuel is not economical. However, at costs of less than $\$ 2.50$, biodiesel would be considered by coal mines and by metal mines if less than $\$ 2.00$.

Participants: Applied Economics, University of Minnesota

Sponsoring Organization(s): Applied Economics, University of Minnesota, U.S. Department of Agriculture-Cooperative State Research, Education, and Extension Service

Point of Contact: J.E. Fruin, Applied Economics, University of Minnesota, St. Paul, MN 55108, phone 612.625.8720.

\section{Papers:}

Fruin, J. E. "The Transportation Industry in Rural America." In press, The Encyclopedia of Rural America.

Fruin, J. and D. Halbach (1996). "The Influence of Rural Road Quality on Vehicle Fuel Consumption." 1996 Semisesquicentennial Transportation Conference, May 13-14, lowa State University Center for Transportation Research and Education.

Additional Information: CRIS Accession No.: 9164964 


\section{Project Title:}

Biodiesel Blends in a DDC Series 60 Engine at High Altitude

Background: Not available.

Objective: To examine regulated emissions for neat soy-based biodiesel with commercial No. 2 diesel fuel using a 1991 model DDC Series 60 heavy-duty diesel engine.

Status: July 1994-August 1994

\section{Accomplishments:}

- Thirty-one transient tests were conducted on both fuels. The diesel reference fuel was tested before and after each blend to permit corrections for engine drift. One cold and three hot runs were made for each fuel. Cold, hot, and composite regulated emissions were reported.

- Biodiesel significantly decreased $\mathrm{HC}, \mathrm{CO}$, and particulate emissions, but increased $\mathrm{NO}_{x}$ emissions.

- The data were analyzed to predict blend-diesel modifications necessary to produce $\mathrm{NO}_{\mathrm{x}}$ neutral blends relative to the commercial diesel.

Participants: Colorado School of Mines and National Renewable Energy Laboratory

Sponsoring Organization(s): U.S. Department of Energy Office of Heavy Vehicle Technologies

Point of Contact: Michael Graboski, Colorado School of Mines, Colorado Institute for Fuels and Engine Research, Golden, CO 80401, phone 303.273.3246 or 303.299.3143, fax 303.299.3142.

\section{Papers:}

Graboski, M.S. (1994). Emissions from Biodiesel Blends and Neat Biodiesel from a 1991 Model Series 60 Engine Operating at High Altitude.

Graboski, M.S., J.D. Ross, R.L. McCormick, and B.K. Bailey (1994). Transient Emissions from No. 2 Diesel and Biodiesel Blends in a DDC Series 650 Engine. In preparation, to be submitted to SAE. 


\section{Project Title:}

Bioblended Fuel for Use in Light-Duty Compression Ignition Engines

Background: The intention for this project was to develop baseline performance information on biodiesel use in this type of engine.

Objectives: Examine the blending of biodiesel fuel with ethanol to form a bioblended fuel for use in light-duty compression ignition engines. The project examined engine/fuel performance in the areas of emissions, fuel economy, driveability, durability, and cost of operation. Primary testing was done on an engine dynamometer. The secondary testing was involved the use of a chassis dynamometer where a research vehicle was evaluated using the bioblended fuel. Depending on how the first two phases looked, road testing for driveability, durability, and fuel economy made up the final phase of the research.

\section{Status: FY 1995-FY 1996}

\section{Accomplishments:}

- The contractors found general improvement in the emissions with blends of biodiesel and ethanol compared with petroleum-based diesel. Levels of $\mathrm{HC}$ emissions were lower with blends of biodiesel, especially during open throttle conditions. $100 \%$ biodiesel yielded a $71.4 \%$ drop in $\mathrm{HC}$ emissions.

- Levels of $\mathrm{NO}_{x}$ emissions generally increased with increased concentrations of biodiesel when blended with No. 2 diesel; however, as the concentration of ethanol in the mix increased, the levels of $\mathrm{NO}_{x}$ decreased.

- Particulate emissions were reduced by $81 \%$ over No. 2 diesel with a blend of $15 \%$ ethanol and $85 \%$ biodiesel.

- In addition, no compatibility problems were identified with fuel system components at any concentration of biodiesel, of ethanol. However, some cold start problems and reduced fuel economy were identified.

Participants: Mankato State University

Sponsoring Organization(s): Great Lakes Regional Biomass Energy Program

Point of Contact: Drs. Bruce Jones \& Kirk Ready, Mankato State University, P.O. Box 8400, Mankato, MN 56002-8400, phone 507.389.6700.

Papers:

Draft Report: Bioblended Fuel for Use in Light-Duty Compression Ignition Engines. 


\section{Project Title:}

Biodiesel Steamboat Test on the Ohio River

Background: The purpose of this study is to test the operational and emissions levels of a cleaner fuel on the Ohio River.

Objective: To develop and test a biodiesel steamboat operating under normal conditions on the Ohio River with help from PUC of Ohio and the University of Cincinnati.

Status: September 1995-November 1995.

Accomplishments:

- A steamboat operating on diesel, a 50/50 biodiesel/diesel blend and $100 \%$ biodiesel was tested.

- The steamboat was measured for $\mathrm{CO}$ and particulates while operating under loaded conditions.

Participants: Public Utilities Company and University of Cincinnati

Sponsoring Organization(s): Public Utilities Company, University of Cincinnati

Point of Contact: Bill Manz, Public Utilities Commission, 77 S. High Street, 26th Floor Columbus, $\mathrm{OH}$ 43215, phone 614.466.7429; Claude Eggleton, Public Utilities Commission, phone 614.466.7707, e-mail claude.w.eggleton @ohio.gov; Carl Tucker, Public Utilities Commission, phone 614.752.9838; Dan Durbin, University of Cincinnati, 5559 Foxrun Court, Cincinnati, OH 45239, phone 513.542.0795, e-mail daniel.durbin @uc.

Paper: Two videos and report to be released in the summer of 1997. 


\section{Project Title:}

Biodiesel Use in Underground Metal and Non-Metal Mines

Background: As a result of the OPEC crisis, a significant amount of research on biodiesel and other domestically produced fuel was conducted by universities and government agencies. The general conclusion at that time was that biodiesel was a technically acceptable substitute, replacement, or blending stock for conventional petroleum diesel, but that its costs were prohibitive compared to petroleum-based diesel fuel. Concern about the health impacts of diesel fuel exhaust and proposed regulations has spurred the recent activities to commercialize biodiesel in North America and opened doors for its use in confined areas such as underground mines.

Objective: To outline the benefits and costs of biodiesel use in underground mines.

Status: May 1997

\section{Accomplishments:}

- The use of biodiesel in underground mines is an easily implemented control strategy, which has been demonstrated to reduce diesel PM and other diesel emissions.

- Biodiesel significantly reduces the Ames mutagenicity of diesel particulates.

- Biodiesel complements diesel and aftertreatment technologies and can be used as a stand-alone strategy or in combination with these future technologies.

- Biodiesel use provides other benefits to society such as reducing $\mathrm{CO}_{2}$, reducing dependence on foreign petroleum, and creating domestic manufacturing jobs.

Participants: MARC-IV Consulting, Inc

Sponsoring Organization(s): MARC-IV Consulting, Inc, Consulting

Point of Contact: Alan Weber, MARC-IV Consulting Inc., 402 Oak Street, Ashland, MO 65010, phone 573.657.5537, fax 573.657.1058, e-mail aweber@marciv.com.

\section{Paper(s):}

Howell, S.; Weber, J.A. (1997). Biodiesel Use in Underground Metal and Non-Metal Mines. Keamey, MO: MARC-IV Consulting, Inc. 


\section{Project Title:}

Biofuels Research

Background: Biofuels, made from agricultural crops, have the potential for making significant contributions toward achieving environmental, energy security, and increased demand for agricultural commodities goals. Additional emission and engine performance data about ethanol and ethanol blends need to be obtained and the benefits that will result from their increased use need to be provided to representatives of the biofuels industry, engine manufacturers, and state and federal agencies developing regulations.

\section{Objectives:}

- Conduct emissions and engine performance tests using a range of ethanol and gasoline blends with specific emphasis on $\mathrm{NO}_{x}$ and VOCs in the exhaust gases.

- Cosponsor working conferences on ethanol and biodiesel issues.

- Evaluate promising technologies for reducing the cost of biofuels production and provide limited support to enhance selected technologies.

Status: December 1996

Accomplishments: Funds under this project were previously distributed to the Eastem Regional Research Center for Biofuels Research.

Participants: U.S. Department of Agriculture-Agricultural Research Service, Eastem Regional Research Center

Sponsoring Organization(s): U.S. Department of Agriculture-Agricultural Research Service, Beltsville, Maryland

Point of Contact: Jill Statka, Agricultural Research Service, Eastem Regional Research Center, 301-504-5100

Papers: None available at this time.

Additional Information: CRIS Accession No.: 9146500 


\section{Project Title:}

Chemical and Biological Characterization of Emissions from a Biodiesel-Fueled Underground Mining Diesel Engine with and without an Oxidation Catalytic Converter

Background: Very few comprehensive studies have been conducted on vegetable-based fuels, such as methyl soyate or biodiesel fuel, on engines designed for use in underground mining operations. Even less information is available on the impact of biodiesel fuels on toxic emissions such as PAHs, nPAHs, and mutagenic activity. The purpose of this study was to provide some of the detailed emission information necessary to evaluate the impact of using a biodiesel fuel on potentially health-related emissions from a diesel engine typical of those used in underground mining operations.

\section{Objectives:}

- Measure the toxic emissions, particularly PAHs, nPAHs, and mutagenic activity as well as alkaline-equivalent $\mathrm{HC}$ 'distribution in the particle and vapor phase samples obtained from an underground mining engine operated under transient conditions with three fuels with and without OCCs as control devices.

- Evaluate the effectiveness of the biodiesel fuels and control devices for potential use in the underground mine environment.

Status: December 30, 1995

\section{Accomplishments:}

- The amount of solid, carbonaceous component of the DPM appeared to be lower with biodiesel fuel as compared to the diesel fuel. Use of the blend fuel typically resulted in emissions reductions less than found with the diesel fuel.

- Major differences between diesel and biodiesel fuels were probably due to the presence of unbumed methyl esters in the extracts of exhaust samples obtained when biodiesel fuel was used. Use of the OCC for the $90 / 10$ cycle decreased the magnitude of the unbumed fuel peaks.

- Whether or not the OCC was used, lower particle-associated and vapor phase mutagenic activity was typically found when using the biodiesel fuel than with the diesel fuel.

Participants: Michigan Technological University

Sponsoring Organization(s): Michigan Technological University, U.S. Bureau of Mines Twin Cities Research Center

Point of Contact: Susan T. Bagley, Michigan Technological University, 1400 Townsend Drive, Houghton, Ml 49931-1295, phone 906.487.2385.

\section{Paper(s):}

Bagley, S.T.; Gratz, L.D.; Johnson, J.H. (1995). Chemical and Biological Characterization of Emissions from a Biodiesel-Fueled Underground Mining Diesel Engine with and without an Oxidation Catalytic Converter. Houghton, Ml: Michigan Technological University. Available from the National Biodiesel Board, Jefferson City, MO 65110. 
Project Title:

Comprehensive Emissions and Chemical Characterization of Rapeseed Oil-Derived Biodiesel

Background: The Montana Department of Environmental Quality in cooperation with RBEP and Chrysler were interested in developing data needed by potential markets and producers of rapeseed-based ethyl or methyl esters. This interest was the genesis for this project.

\section{Objectives:}

- Gain commercial acceptance and development of REE and RME.

- Provide emissions and performance data from tests conducted by an industry-accepted laboratory (of special interest are the results from toxic air emissions).

- Target heavy-duty diesel applications, especially environmentally sensitive applications such as the tourism industry's buses and trucks.

\section{Status: FY 1995-FY 1996}

Accomplishments:

- The complete biodiesel testing using a Cummins B diesel engine was completed by March 1996.

- Completion and publication of final testing report was concluded September 1996.

Participants: The University of Idaho; Montana Department of Environmental Quality; Dodge Truck Division of the Chrysler Corporation; Cummins Engine Company; J.R. Simplot; Koch Agricultural Services Company; and, the University of Califomia-Davis.

Sponsoring Organization(s): Pacific Northwest and Alaska Regional Biomass Energy Program

Point of Contact: Howard Haines, Department of Environmental Quality, P.O. Box 200901, Helena, MT 59620-0901, phone 406.444.6773, fax 406.444.1804, e-mail hhaines@mt.gov.

Papers:

Sharpe, C. A. (1996). Emissions and Lubricity Evaluation of Rapeseed Derived Biodiesel Fuels. 


\section{Project Title:}

\section{DDC 6V-71N Emission Testing on Diesel \& Biodiesel Blend}

Background: The EPA has issued rules that require transit properties to reduce emissions on their engines after January 1, 1995, when rebuilding or replacing them. The test is intended to demonstrate reduction in emissions on older coach engines. If successful, a methyl soyate/ diesel blend could then be introduced into the marketplace as a means or option to comply, in part, with the EPA rulemaking.

\section{Objectives:}

- Demonstrate and determine whether a methyl soyate (biodiesel) blend could reduce emissions from older engines.

- Set up a test engine in its received condition in the EPA transient test cell and verifies engine performance.

- Conduct regulated gaseous and particulate EPA emissions tests on No. 2 EPA diesel fuel and on a $20 \% / 80 \%$ methyl soyate/No. 2 EPA diesel blend.

- Compile, document, and summarize the results for NBB.

Status: July 12, 1994

\section{Accomplishments:}

- The results of the testing indicate that the use of a $20 \% / 80 \%$ blend, even in a well-used engine, significantly reduced emission of THC and $\mathrm{CO}$.

- Extremely high particulate values with petrodiesel, particularly the soluble organic fraction of the particulate, indicated the need for a rebuild of the engine, which was accomplished.

- Biodiesel increases the SOF portion of the particulates and biodiesel's measured particulate reduction using engines with high SOF is diminished although visible reduction (opacity reduction) is still similar.

- After the rebuild a $\mathrm{B} 20$ blend, exhaust catalyst, and $4^{\circ}$ engine retard produced reductions in all regulated emissions compared to the baseline diesel.

Participants: Fosseen Manufacturing \& Development and ORTECH International

Sponsoring Organization(s): National Biodiesel Board

Point of Contact: Ms. Bev Thessen, National Biodiesel Board, P.O. Box 104898, Jefferson City, MO, 65110-4898, phone 573.635.3893, fax 573.635.7913, e-mail biodiesel @ sockets.net.

\section{Paper:}

Fosseen Manufacturing and Development. (July 1994). DDC6V-71N Emission Testing on Diesel and Biodiesel Blend. NSDB 219-1. Jefferson City, MO: National SoyDiesel Board. Work performed by Fosseen Manufacturing \& Development, Radcliffe, IA. 
Project Title:

DDC 6V-92TA MUI Coach Upgrade Emission Optimization on $20 \% / 80 \%$ Soy/Diesel Blends

Background: Increasingly stringent legislation on engine exhaust emission levels has resulted in research to use alternative fuels and blends to reduce emissions, especially $\mathrm{NO}_{x}$ and particulates.

\section{Objectives:}

- Document emissions on the test engines with EPA-base diesel, $20 \% / 80 \%$ ME blend, a $30 \% / 70 \%$ ME blend and a $20 \% / 80 \%$ blend with the use of a catalyst.

- Optimize timing with the $20 \% / 80 \%$ blend toward $\mathrm{NO}_{\mathrm{x}}$.

- Carry out EPA testing with and without a catalyst on the $20 \% / 80 \%$ blend.

Status: November 30, 1993-September 30, 1994 Complete.

Accomplishments:

- Increasing emissions reductions are found on the $20 \%$ and $30 \%$ blends for $\mathrm{CO}$ and $\mathrm{HC}$.

- $\mathrm{NO}_{x}$ is marginally increased and PM is marginally decreased with the optimized engine.

- The PM composition is changed with ME blends and carbon or insoluble fraction is observed.

- The OCC achieves a significant reduction in particulates.

Participants: Fosseen Manufacturing \& Development, Ltd.

Sponsoring Organization(s): National Biodiesel Board

Point of Contact: Ms. Bev Thessen, National Biodiesel Board, P.O. Box 104898, Jefferson City, MO, 65110-4898, phone 573.635.3893; fax 573.635.7913; e-mail

biodiesel@sockets.net.

\section{Paper:}

Fosseen Manufacturing and Development. (September 1994). DDC 6V-92TA MUI Coach Upgrade Emission Optimization on 20\%/80\% Soy/Diesel Blend. NBB 260-2 and 231-1. Jefferson City, MO: National Biodiesel Board. Work performed by Fosseen Manufacturing \& Development, Radcliffe, IA. 


\section{Project Title:}

Development of Biodiesel for Use in High-Speed Diesel Engines

Background: Altemative fuels, which will improve the environment, reduce the use of petroleum reserves, reduce foreign imports, and increase use of renewable fuels, are a U.S. prionity. Locally produced rapeseed may be a solution to both petroleum depletion and environmental pollution.

Objectives:

- Find acceptable recipes for RME and REE.

- Determine whether RME and REE are acceptable substitutes for diesel fuel.

Status: Completed

\section{Accomplishments:}

- Biodiesel (both REE and RME) have been found to be acceptable substitutes for diesel fuel, performing normally in unmodified diesel engines.

- Recipes for producing both RME and REE have been developed and used to produce demonstration quantities of fuel.

- Biodiesel is safer because the flashpoint is more than 100\%F higher than that of diesel.

- Biodegradability of rape esters was higher than the biodegradability of reference dextrose and much higher than diesel fuel.

- Toxicity of biodiesel was at least 15 times less than diesel and probably much lower.

- Emissions tests have shown a reduction in $\mathrm{HC}, \mathrm{CO}$, and $\mathrm{NO}_{x}$ and an increase in $\mathrm{CO}_{2}$ and PM. The results for PM are not significantly different from diesel, but the others were.

Participants: University of Idaho

Sponsoring Organization(s): Pacific Northwest and Alaska Regional Biomass Energy Program, Idaho Department of Water Resources, Energy Division, U.S. Department of Agriculture-Agricultural Research Service Cooperative Agreement

Point of Contact: Dr. Charles Peterson, Department of Agricultural Engineering, University of Idaho, Moscow, Idaho 83844, phone 208.885.7906, fax 208.885.8923, e-mail

peterson @ novell.uidaho.edu.

\section{Paper(s):}

Peterson, C.; Reece, D.; Thompson, J.; Beck, S.; Chase, C. (1994). "Development of Biodiesel for Use in High-Speed Diesel Engines." Proceedings of the 6th National Bioenergy Conference, vol. I, Bioenergy '94, Reno-Sparks, NV. Westem Regional Biomass Energy Program, pp 97-104. 


\section{Project Title:}

Effects of an Oxidation Catalytic Converter and a Biodiesel Fuel on the Chemical, Biological and Particle Size Characteristics of Emissions from an IDI Diesel Engine

Background: This study was conducted to obtain additional information on exhaust emissions and potential health effects from an indirect injection diesel engine, typical of those used in underground mines. This study will test the effects of using soy-derived, fatty acid mono-ester (or biodiesel) fuel and an OCC.

\section{Objectives:}

- Obtain samples of particulate and vapor phase organic material from a typical mine diesel engine operating on No. 2 diesel fuel and biodiesel fuel with and without an OCC control device.

- Determine the effects of fuels and OCC on the size and distribution of the diesel PM.

- Analyze all data obtained as part of this project in order to evaluate the effectiveness of the biodiesel fuels and control devices for potential use in the underground mine environment as a method for controlling TPM emissions.

Status: January 1997

\section{Accomplishments:}

- The project found the combination of reduced particles with deep-lung penetration would support the use of this biodiesel fuel for TPM-control with diesel engines in confined spaces.

- In order to achieve the maximum particulate reduction, an OCC is recommended when using biodiesel fuel for these applications.

- The use of biodiesel fuel should not increase any of the potentially toxic, health-related emissions that were monitored as part of the study.

- Further testing of this fuel in the field with an appropriate OCC is warranted to determine the effects of the fuel and the OCC on diesel PM in the ambient air.

Participants: Michigan Technology University, University of Minnesota

Sponsoring Organization(s): National Biodiesel Board

Points of Contact: Ms. Bev Thessen, National Biodiesel Board, P.O. Box 104898, Jefferson City, MO, 65110-4898, phone 573.635.3893, fax 573.635.7913, e-mail biodiesel @ sockets.net. Susan T. Bagley, Department of Biological Sciences, Department of Mechanical Engineering, Michigan Technological University, 1400 Townsend Drive, Houghton, Ml 49931-1295, phone 906.487.2385. Joseph F. McDonald, Center for Diesel Research, Department of Mechanical Engineering, University of Minnesota, 111 Church Street, SE, Minneapolis, MN 55455-0111, phone 612.725.4750.

\section{Paper:}

Bagley, S.T.; Gratz, L.D.; Johnson, J.H.; McDonald, J.F. (1997). Effects of an Oxidation Catalytic Converter and a Biodiesel Fuel on the Chemical, Biological, and Particle Size Characteristics of Emissions from and IDI Diesel Engine. Houghton, MI: Michigan Technological University. Available from the National Biodiesel Board, Jefferson City, MO 65110. 


\section{Project Title:}

Effects of Methyl Esters of Tallow and Grease on Exhaust Emissions and Performance of a Cummins L10 Engine

Background: With the passage of the CAAA- 90 came a renewed interest in clean-buming fuels. This research project was one of many that tested the emissions performance of biodiesel to understand its emissions-reducing potential.

Objectives: To determine the effect of TME and GME on the exhaust emissions from a Cummins L10-280E diesel engine

Status: September 16, 1993

Accomplishments:

- Exhaust emissions and performance tests with TME and GME fuels showed significant reduction in $\mathrm{HC}, \mathrm{CO}$, and particulates compared to low -sulfur base diesel fuel.

- $\mathrm{NO}_{x}$ emissions and fuel consumption increased.

- The fuel consumption and emissions responses to the TME and GME fuels were essentially the same as those to SME fuels.

Participants: IIT Research Institute, National Institute for Petroleum and Energy Research

Sponsoring Organization(s): Fats and Proteins Research Foundation, Inc.

Point of Contact: William Marshall, IIT Research Institute, National Institute for Petroleum and Energy Research, 220 North Virginia Ave., Bartlesville, OK 74005, phone 918.336.2400, fax 918.337.4365.

\section{Paper(s):}

Marshall, .W. (September 1993). Effects of Methyl Esters of Tallow and Grease on Exhaust Emissions and Performance of a Cummins L10 Engine. \#B08861. Ft. Myers Beach, FL: Fats and Proteins Research Foundation, Inc. Work performed by National Institute for Petroleum and Energy Research, Bartlesville, OK. 


\section{Project Title:}

Emission Characteristics of Methyl Soyate in Underground Mining Engines

Background: Underground mining is a particularly sensitive application for any engine because of the effects of emissions on air quality and the direct impacts on groundwater. This program focuses on the use of biodiesel fuel in the large, low-speed diesel engines characteristic of underground mining applications.

\section{Objectives:}

- Establish engine settings and conduct emission tests of test fuel on mine type diesel engines.

- Conduct chemical and biological assays to evaluate diesel exhaust for potential health effects.

- Test quantities of SME for engine emission evaluation from the AURI test pilot plant.

- Compare emissions from methyl ester fuels, specifically TME and distilled methyl esters of waste yellow grease, with results from previous SME testing to determine whether exhaust emissions are essentially similar.

Status: Project completed.

Accomplishments: Will be detailed in final project report.

Participants: Max E. Norris, Agricultural Utilization Research Institute c/o Southwest State University, Marshall, MN 56258

Sponsoring Organization(s): U.S. Department of Agriculture-Cooperative State Research, Education, and Extension Services

Point of Contact: Max E. Norris, Agricultural Utilization Research Institute clo Southwest State University, Room ST107, 1501 State Street, Marshall, MN 56258, phone 507.537.7440

Papers: None available at this time. 


\section{Project Title:}

\section{Emission Performance of Biodiesel Fuels in Heavy-Duty Pickup Truck}

Background: There has been some work done on the use of biodiesel and biodiesel blends in heavy-duty pickup trucks, specifically at the University of Idaho with a Dodge pickup powered by the Cummins 5.9 L B-series engine. In this work, regulated emissions were measured over the FTP 75 cycle. The goal of this work is to gather much more detail of the emissions performance of a representative domestic pickup truck powered by a diesel engine. These data can then serve as a guide for emissions reduction methodologies to be developed in DOE's Office of Heavy Vehicle Technologies. In addition, efforts will be made to measure off-cycle emissions, including PM, in order to quantify the effect of biodiesel and biodiesel blends on these emissions.

\section{Objective:}

- Produce comprehensive emission and performance data on biodiesel and diesel-biodieselblends in the Navistar-powered Ford F-250. The fuel matrix will contain regular diesel fuel B-20 and B-100 fuels with SME, as well as Fischer-Tropsch diesel.

- Pay special attention to the measurement of unregulated emissions and modal analysis of particulate mass.

Status: FY 1997-FY 1998 (F-T diesel)

Accomplishments:

- The project will show the influence of biodiesel and biodiesel blends and Fischer Tropsch diesel on emissions in comparison with conventional diesel fuel in a commercially available heavy-duty pickup.

- A lookup table with information on emissions as a function of vehicle speed and acceleration will be constructed for most of the vehicle's operating range.

- Additional work will include bag speciation of HCs and determination of aldehydes over the FTP and other cycles.

Participant: Oak Ridge National Laboratory

Sponsoring Organizations: U.S. Department of Energy Office of Heavy Vehicle Technologies.

Point of Contact: Brian West, Oak Ridge National Laboratory, P.O. Box 2009, MS-8087, Oak Ridge, TN 37831-8087, phone 423.574.0248, fax 423.574.2102.

Papers: None available at this time. 


\section{Project Title:}

Emission Performance of Selected Biodiesel Fuels as a Platform for Future Diesel Altemative Evaluations

Background: There is a great interest in biodiesel in many areas, both in Europe and in North America. Intemationally, a lot of information on biodiesel has been published. However, the engines used in many cases have been old, high-emitting farm tractor diesel engines. One can expect that different engine concepts react differently. This is especially true when exhaust gas aftertreatment is used for emission reduction. There are no extensive analysis data for various engine altematives and for the unregulated emissions. This project is being done jointly with VTT Energy of Finland.

\section{Objectives:}

- To produce emission and performance data on biodiesel and diesel-biodiesel-blends in different diesel engines. Advanced diesel engines of different sizes and for different applications will be used. Some of the test engines will have exhaust gas aftertreatment. The fuel matrix will contain regular and reformulated diesel fuel as reference.

- Pay special attention to the measurement of unregulated emissions and analysis of particulate composition.

Status: January 1997-June 1999

\section{Accomplishments:}

- The project will show the influence of biodiesel and biodiesel blends on emissions in comparison with conventional and improved diesel fuel qualities in modem diesel engines.

- It will also show the fuel effect on diesel exhaust aftertreatment devices.

- A final report containing detailed information on exhaust gas composition and exhaust particulate biological effects will be produced. The emission performance of different biodiesels and biodiesel blends in comparison with both conventional and reformulated diesel will be discussed in detail.

- Conclusions on the optimum usage of different biodiesel qualities will be drawn.

Participants: Oak Ridge National Laboratory; VTT Energy, Finland.

Sponsoring Organization(s): Intemational Energy Agency Altemative Motor Fuels Committee; DOE Office of Heavy Vehicle Technologies; Technology Development Centre of Finland (TEKES).

Point of Contact: John Storey, OM, P.O. Box 2009, MS-8087, Oak Ridge, TN 37831-8087, phone 423.574.0574, fax 423.574.2102.

Paper: None available at this time. 


\section{Project Title:}

Emissions and Engine Performance from Blends of Soya and Canola Methyl Esters with ARB \#2 Diesel in a DCC 6V92TA MUI Engine

Background: Research conducted using raw, degummed vegetable oils during the early 1980 s demonstrated that diesel engines can operate with vegetable oils. Additional research demonstrated that methyl esters derived from vegetable oils create fewer difficulties that the use of vegetable oil in heavy-duty diesel engines.

\section{Objectives:}

- A DDC 6V92TZ MUl engine was operated on several blends of EPA No. 2 diesel, CARB No. 2 diesel, SME, and CME.

- Various fuels and fuel blend characteristics were determined and engine emissions from these fuels and blends were compared.

Status: October 1995

\section{Accomplishments:}

- The research found that SME and CME/No. 2 diesel blends, in conjunction with technologies that reduce the soluble fraction of particulate emissions, merit further exploration as emissions reducing fuel options for North American mass transits.

- However, SME/No. 2 diesel fuel blends are not deemed a viable mass transit "transition fuel" for Los Angeles basin and Califomia conditions.

Participants: The ADEPT Group, Inc.

Sponsoring Organization(s): , U.S. Department of Agriculture, Califomia Department of Food and Agriculture, Division of Measurements Standards, lowa State University, Department of Mechanical Engineering.

Point of Contact: Alex Spataru and Claude Romig, The ADEPT Group, Inc.; 10920 Wilshire Blvd., \#1203, Los Angeles, CA 90024, phone 310.208.8074, fax 310.208.0129

\section{Paper:}

Spataru, A.; Romig, C. (1995). "Emissions and Engine Performance from Blends of Soya and Canola Methyl Esters with ARB \#2 Diesel in a DCC 6V92TA MUI Engine." Emissions Processes and Control Technologies in Diesel Engines; October 16-19, 1995, Toronto, Ontario. SAE 952388. Warrendale, PA: Society of Automotive Engineers, Inc., pp. 179-188. 


\section{Project Title:}

Emissions and Performance Characteristics of a 4-Stroke, Direct Injected Diesel Engine Fueled with Blends of Biodiesel and Low Sulfur Diesel Fuel

Background: More stringent emissions legislation and the availability vegetable oils have increased the evaluation of SMEs as diesel fuel substitutes. The purpose of this study is to evaluate the potential for using SME as a blending agent with low-sulfur diesel fuel and to optimize the performance and emissions characteristics of a direct-injected, four-stroke engine.

Status: February 27-March 2, 1995

Objectives:

- Conduct testing on $100 \%$ low-sulfur diesel to a baseline for emissions, fuel consumption, and performance.

- Characterize emissions and performance for blends at standard diesel calibration.

- Conduct injection timing swings and evaluate for each blend.

- Identify the blends, vary injection pressure and timing at discrete points in the engine map, and determine an optimum strategy.

- Select the best blend and evaluate the potential benefits of an oxidation catalyst

- Evaluate the level at which EGR helps reduce $\mathrm{NO}_{x}$

- Compare the results against the baseline test results.

Accomplishments:

- In comparison with the baseline, biodiesel blends generally result in lower black smoke emissions and substantially lower particulate emissions.

- Higher $\mathrm{NO}_{x}$, volatile particles, and fuel consumption were observed as SME use is increased in the unmodified engine.

- The use of $20 \%$ and $50 \%$ blends saw a decrease in $\mathrm{NO}_{\mathrm{x}}$, particulates. and fuel consumption but the three were not achieved simultaneously.

- Optimizing the engine calibration with a $20 \%$ blend caused a decrease in $\mathrm{NO}_{x}$, particulates and fuel consumption simultaneously.

- EGR can provide a decrease in $\mathrm{NO}_{x}$ but with a substantial penalty in fuel economy and some other emissions.

Participants: FEV of America, Navistar Intemational. and Society of American Engineers

Sponsoring Organization(s): National Biodiesel Board

Point of Contact: Ms. Bev Thessen, National Biodiesel Board, P.O. Box 104898, Jefferson City, MO, 65110-4898, phone 573.635.3893, fax 573.635.7913, e-mail biodiesel @ sockets.net. Robert Last, FEV of America,25899 West Twelve Mile Road, Suite 130, Southfield, Ml 480341800, phone 810.352.1400, fax 810.352.1404.

\section{Paper:}

Last, R.J.; Kruger, M.; Dumholz, M. (1995). "Emissions and Performance Characteristics of a 4-Stroke, Direct Injected Diesel Engine Fueled with Blends of Biodiesel and Low Sulfur Diesel Fuel." International Congress and Exposition, February 27- March 2, Detroit, MI. SAE 950054. Warrendale, PA: Society of Automotive Engineers, Inc., pp 1-13. 


\section{Project Title:}

Emissions Characteristics of Ethyl and Methyl Ester of Rapeseed Oil Compared with Low Sulfur Diesel Control Fuel in a Chassis Dynamometer Test of a Pickup Truck

Background: The CAA forms the legislative base for fuel, engine, and emissions standards.

\section{Objectives:}

- Compare regulated emissions data included THC, $\mathrm{CO}, \mathrm{CO}_{2}, \mathrm{NO}_{\mathrm{x}}$ and $\mathrm{PM}$, for REE, RME, and diesel control fuel.

- Obtain emissions data for blends of REE and RME with diesel control fuel at the $20 \%$ and $50 \%$ levels.

Status: April 1995

Accomplishments:

- $\mathrm{HC}$ and CO were reduced by around $50 \%$ when $100 \%$ vegetable oil fuel was compared to low-sulfur diesel control fuel.

- PM increased when $100 \%$ vegetable oil fuel was compared to low-sulfur diesel control fuel.

Participants: University of Idaho, Los Angeles Metropolitan Transit Authority, and Pacific Northwest and Alaska Regional Biomass Energy Program

Sponsoring Organization(s): Pacific Northwest and Alaska Regional Biomass Energy Program, The Idaho Department of Water Resources, Energy Division

Point of Contact: Dr. Charles Peterson, Department of Agricultural Engineering, University of Idaho, Moscow, ID 83844, phone 208.885.7906, fax 208.885.8923, e-mail peterson@novell.uidaho.edu.

\section{Paper(s):}

Peterson, C.L.; Reece, D. (1995) Emissions Characteristics of Ethyl and Methyl Ester of Rapeseed Oil Compared with Low Sulfur Diesel Control Fuel in a Chassis Dynamometer Test of a Pickup Truck. ASAE Paper No. 94-6532. Moscow, ID: University of Idaho. Available from the American Society of Automotive Engineers, St. Joseph, MI 49085. 


\section{Project Title:}

Emissions Characteristics of Soy Methyl Ester Fuels in an IDI Compression Ignition Engine

Background: As part of the ongoing program to control the emissions of diesel-powered equipment used in underground mines, the U.S. Bureau of Mines evaluated exhaust emissions from a compression ignition engines using oxygenated diesel fuels and a diesel oxidation catalyst.

\section{Objectives:}

- Compare and characterize gaseous and particulate emissions from a heavy-duty diesel engine using a typical low-sulfur, No. 2 petroleum diesel fuel, an SME blend with petroleum diesel fuel, and a $100 \%$ SME fuel.

- Characterize basic combustion phenomena to help explain emissions and performance results.

Status: March 1995

Accomplishments: Not available.

Participants: University of Minnesota

Sponsoring Organization(s): U.S. Bureau of Mines

Point of Contact: Joseph F. McDonald, Center for Diesel Research, Department of Mechanical Engineering, University of Minnesota, 111 Church Street, SE, Minneapolis, MN 55455-0111, phone 612.725.4750.

\section{Paper(s):}

McDonald, J.F.; Purcell, D.L.; McClure, B.T.; Kittleson, D.B. (1995). "Emissions Characteristics of Soy Methyl Ester Fuels in an IDI Compression Ignition Engine." Intemational Congress and Exposition, February 27- March 2, Detroit, MI. SAE 950400. Warrendale, PA: Society of Automotive Engineers, Inc., pp. 1-17. 


\section{Project Title:}

Emissions Characteristics of Soy Methyl Ester Fuels in an Underground Mining Diesel Engine with and without Diesel Oxidation Catalyst Aftertreatment

Background: Diesel-powered equipment is used in underground mines because it is more powerful and mobile than electric-powered equipment. However, diesel exhaust emissions pose a potential health hazard to mine workers. Therefore, the project will find and test altematives to diesel fuels.

Objective: To determine whether SME, with the addition of a diesel OCC exhaust aftertreatment device, can reduce exhaust pollutants from heavy-duty, diesel-powered, underground mining equipment sufficient to economically replace expensive, complicated exhaust aftertreatment devices currently used for particulate emission reductions.

Status: Completed December 31, 1994

Accomplishments:

- The SME fuel and the 30/70 (SME/No. 2 diesel) blend fuel did not cause any fuel-related problems in the pre-chamber, naturally aspirated engine.

- Neat SME or a blend with 30/70 (SME/No. 2 diesel) could potentially be used as an emissions reduction technology for diesel usage in confined spaces, such as underground mines.

- The reduced emissions from these fuels, along with increased biodegradability and higher flash points, could provide safety and health improvements over petroleum diesel fuels.

Participants: University of Minnesota

Sponsoring Organization(s): Agriculture Utilization Research Institute, National Biodiesel Board, U.S. Bureau of Mines-Twin Cities Research Center, and U.S. Department of Agriculture

Points of Contact: Ms. Bev Thessen, National Biodiesel Board, P.O. Box 104898, Jefferson City, MO, 65110-4898, phone 573.635.3893, fax 573.635.7913, e-mail biodiesel@sockets.net.. J. McDonald, D.L. Purcell, and B.T. McClure, Center for Diesel Research, Department of Mechanical Engineering, University of Minnesota, 111 Church Street, SE, Minneapolis, MN 55455-0111, phone 612.725.4750

\section{Paper:}

McDonald, J.; Purcell, D.L.; McClure, B.T. December 31, 1994. Emissions Characteristics of Soy Methyl Ester Fuels in an Underground Mining Diesel Engine with and without Diesel Oxidation Catalyst Aftertreatment. Jefferson City, MO: National Biodiesel Board. 


\section{Project Title:}

Emissions from Biodiesel Blends and Neat Biodiesel from a 1991 Model Series 60 Engine Operating at High Altitude

Background: The purpose of this study was to investigate the effect of adding SME, biodiesel, to a base diesel fuel on emissions from a DDC Series 60 engine.

Objective: To determine the effects of adding SME (biodiesel) to base diesel fuel on emissions from a DDC Series 60 engine.

Status: September 1994

Accomplishments:

- The results of the testing are in general agreement with studies on other engines.

- Engine efficiency was found to be the same for biodiesel and biodiesel blends as for the reference fuel.

- Fuel consumption for biodiesel blends can therefore be calculated from diesel fuel economy data.

Participants: Colorado Institute for Fuels and High Altitude Engine Research

Sponsoring Organization(s): Colorado School of Mines

Point of Contact: Michael Graboski, Colorado School of Mines, Colorado Institute for Fuels and Engine Research, Golden, CO 80401, phone 303.273.3246 or 303.299.3143, fax 303.299.3142.

\section{Paper:}

Graboski, M.S.; McCormick, R.L.; Ross, J. (September 1994). Emissions from Biodiesel Blends and Neat Biodiesel from a 1991 Model Series 60 Engine Operating at High Altitude. Golden, CO: National Renewable Energy Laboratory. Work performed by the Colorado Institute for Fuels and High Altitude Engine Research, Golden, CO. 


\section{Project Title:}

Emissions Tests with an On-Road Vehicle Fueled with Methyl and Ethyl Esters of Rapeseed Oil

Background: Comprehensive tests were performed on and on-road vehicle in cooperation with the Los Angeles County Metropolitan Transit Authority emissions testing facility. Tests included both arterial and EPA heavy-duty vehicle cycles. REE and REE and blends were compared with a low-sulfur diesel control fuel. Data include $\mathrm{HC}, \mathrm{CO}, \mathrm{CO}_{2}, \mathrm{NO}_{x_{1}}$ and $\mathrm{PM}$.

Objectives:

- Compare regulated emissions data including $\mathrm{THC}, \mathrm{CO}, \mathrm{CO}_{2}, \mathrm{NO}_{x}$, and PM, for REE, RME, and diesel control fuel.

- Obtain emissions data for $100 \%$ REE, $100 \%$ RME, and $20 \%$ and $50 \%$ blends of both REE and RME with diesel control fuel.

Status: December 1994

Accomplishments:

- The project showed that when $100 \%$ vegetable oil fuel was used compared to low-sulfur diesel control fuel, $\mathrm{HC}$ was reduced by $52.4 \%, \mathrm{CO}$ was reduced by $47.6 \%, \mathrm{CO}_{2}$ increased by $0.9 \%$ and $\mathrm{NO}_{x}$ was reduced by $10.0 \%$. PM increased by $9.9 \%$ when $100 \%$ vegetable oil fuel was compared to low-sulfur diesel control fuel, although this was determined to be statistically insignificant.

- In these tests, $100 \%$ REE reduced $\mathrm{HC}(8.7 \%), \mathrm{CO}(4.3 \%)$ and $\mathrm{NO}_{x}(3.4 \%)$ compared to $100 \%$ RME.

- The absolute value of emission data was higher for the EPA cycle than for the arterial cycle. $\mathrm{HC}$ increased from 0.57 to $0.87 \mathrm{~g} / \mathrm{mi}$; CO from 2.34 to $2.865 \mathrm{~g} / \mathrm{mi}$; CO2 from 657.8 to $703.8 \mathrm{~g} / \mathrm{mi}$; $\mathrm{NO}_{x}$ from 5.88 to $6.41 \mathrm{~g} / \mathrm{mi}$ and $P M$ from 0.305 to $0.44 \mathrm{~g} / \mathrm{mi}$.

Participants: University of Idaho, Los Angeles County Metropolitan Transit Authority

Sponsoring Organization(s): Pacific Northwest and Alaska Regional Biomass Energy Program, Idaho Department of Water Resources, Energy Division, and U.S. Department of Agriculture-Cooperative State Research, Education, and Extension Service

Point of Contact: Charles L. Peterson and Daryl L. Reece, Professor of Agricultural Engineering and Engineering Technician, respectively, University of Idaho, Moscow, ID, 83844-2040, phone 208.885.7906, fax 208.885.8923, e-mail peterson @ novell.uidaho.edu.

\section{Paper:}

Peterson, C.L.; Reece, D.C. "Emissions Tests with an On-Road Vehicle Fueled with Methyl and Ethyl Esters of Rapeseed Oil." ASAE Paper \# 946532. Presented at the 1994 ASAE International Winter Meeting, Atlanta GA, 13-16 December. 
Project Title:

Engine Exhaust Emissions Evaluation of a Cummins L10E When Fueled with a Biodiesel Blend

Background: Petroleum-based diesel fuel has been the fuel of choice for the diesel engine for many years due to abundant supply and low fuel prices. However, methyl esters of animal and vegetable oils (biodiesel) are again being re-evaluated for use as a fuel for modem diesel engines due to their cleaner buming tendencies, other environmental benefits, and energy security reasons.

\section{Objectives:}

- Compare biodiesel and biodiesel/heavy alkylate blends with conventional petroleum diesel fuels when fueling a Cummins L10 engine; and

- Conduct testing at BDM-Oklahoma (NIPER) to measure and compare: (1) regulated EPA exhaust emissions; (2) engine performance; and (3) two $\mathrm{NO}_{x}$-reducing strategies (timing and retard and use of heavy alkylate).

Status: October 1995

\section{Accomplishments:}

- The results of the testing are in general agreement with biodiesel studies that have been conducted on other unmodified two- and four-stroke engines.

- As the concentration of the biodiesel blend increased, the L10 engine produced lower levels of THC, $\mathrm{CO}$, and PM exhaust emissions. The $\mathrm{NO}_{x}$ increased.

- The addition of $20 \%$ heavy alkylates to $\mathrm{B} 20$ provided reductions in $\mathrm{CO}, \mathrm{NO}_{\mathrm{x}}$, and PM. THC emissions were unchanged.

- The L10 engine, while fueled with B20 or B30, produced power during the FTP that was equal to power produced when it was fueled with baseline diesel fuel.

- $\mathrm{NO}_{x}$ emissions on the L10 engine, when fueled with B20, can be successfully reduced below that of baseline diesel fuel by either retarding injection timing or by replacing $20 \%$ of the diesel fuel of the B20 blend with heavy alkylate.

Participants: MARC-IV Consulting, Inc, National Institute for Petroleum and Energy Research-BDM Oklahoma, and the University of Missouri

Sponsoring Organization(s): National Biodiesel Board

Point of Contact: Mr. Steve Howell, MARC-IV Consulting, Inc, 16200 Northridge Road, Kearney, MO, 64060, phone 816.635.5772, fax 816.635.4836, e-mail showell@marciv.com; Dr. Leon Schumacher, University of Missouri Columbia, 235 Agricultural Engineering Bldg., Columbia, MO 65211, phone 573.882.2126, fax 573.884.5650, e-mail leon schumacher@muccmail.missouri.edu.

\section{Paper:}

Marshall, W.; Schumacher, L.G.; Howell, S. (1995). Engine Exhaust Emissions Evaluation of a Cummins L10E When Fueled with a Biodiesel Blend." Fuels and Lubricants, October 16-19, Toronto, Ontario. SAE 952363. Warrendale, PA: Society of Automotive Engineers, Inc., pp. $1-5$. 


\section{Project Title:}

Evaluation of Biodiesel in an Urban Transit Bus Powered by a 1981 DDC8V71 Engine

Background: The problems of emissions in urban transit buses are significant and stringent emissions standards are being considered in legislative initiatives for such vehicles, thus a solution to reduce emissions for in-use buses is needed.

\section{Objectives:}

- Determine operational emissions reductions of a biodiesel blend versus diesel use in a transit bus.

- Conduct heavy vehicle chassis dynamometer emissions testing on a standard 40-foot urban transit bus operating on diesel and a blend of diesel with SME.

- Investigate the effect of ignition timing and exhaust after treatment with an OCC.

Status: November 1, 1994-November 30, 1995

\section{Accomplishments:}

- Biodiesel had its most significant impact on the reduction of emissions of CO and THC during the arterial cycle tests.

- The Central Business District test cycles exhibited the largest emissions reductions in PM and SOF.

- $\mathrm{HC}, \mathrm{CO}$, and PM emissions showed decreases with the installation of an Engelhard catalyst.

- $\mathrm{NO}_{\mathbf{x}}$ decreased when the ignition was retarded.

Participants: Central Business District (test), the New York Bus Composite (test), Southwest Ohio Regional Transit Authority (bus), Petro Canada (diesel), Mobile Sources Division of Environment Canada

Sponsoring Organization(s): National Biodiesel Board and Mobile Sources Division of Environment Canada

Point of Contact: Peter Howes, Greg Rideout, Environment Canada, Technology Development Directorate, Environmental Technology Centre, Ottawa Ontario, K1AOH3.

\section{Paper:}

Howes, P.; Rideout, G. (Unpublished Report). November 30, 1995. Evaluation of Biodiesel in an Urban Transit Bus Powered by a 1981 DDC8V71 Engine. MSED Report \#95-26743-2. (NBB Research Programs and Projects \# 52025. Ottawa, Ontario: Technology Development Directorate, Environment Canada. 


\section{Project Title:}

Evaluation of Methyl Soyate/Diesel Blend in DDC 6V-92TA Engine: Optimization of $\mathrm{NO}_{\mathrm{x}}$ Emissions

Background: In 1993, EPA regulations were finalized goveming the particulate emissions on model year 1993 and earlier model year urban bus engines that operate in urban areas with 1980 populations of 750,000 or more and that are rebuilt or replaced after January 1, 1995.

\section{Objectives:}

- Evaluate the effect of various blends of SME and diesel fuel on the emissions of a DDC 6V-92TA engine.

- Try to maintain a slightly reduced $\mathrm{NO}_{\mathrm{x}}$ while demonstrating emission reduction on a $20 \% / 80 \%$ SME/No. 2 diesel blend in a 6V-92TA engine.

Status: July 1993

\section{Accomplishments:}

- The project results indicated reduction of all gaseous and particulate emissions except $\mathrm{NO}_{x}$, which showed an approximate increase of $5 \%$ (at the $20 \%$ blend level).

- The catalyst proved to be an effective means of further reducing $\mathrm{CO}, \mathrm{THC}$, and soluble particulates.

Participants: ORTECH Intemational, Fosseen Manufacturing \& Development

Sponsoring Organization(s): Fosseen Manufacturing and Development

Point of Contact: Wendel Goetz, Transportation Systems, ORTECH International, 395 Speakman Drive, Mississauga, Ontario L5K1B3, phone 905.822.4111, fax 905.823.1446.

\section{Paper:}

Goetz, W. (1993). Evaluations of Methyl Soyate/Diesel Blend in a DDC 6V-92TA Engine: Optimization of $\mathrm{NO}_{x}$ Emissions. \#93-E14-36 (Addendum to 93-E14-21). Radcliffe, IA: Fosseen Manufacturing \& Development. Work performed by Ortech International, Mississauga, Ontario. 
Project Title:

Field Trials of Soy Methyl Ester as a Fuel for Diesel Powered Equipment in Underground Mines

Background: This research was conducted in order to determine the effectiveness of SME as a diesel particulate control strategy for diesel-powered underground mining equipment in an actual mining operation.

\section{Objectives:}

- Previous work in indicated that SME fuel with the addition of a diesel OCC exhaust aftertreatment device can reduce exhaust pollutants from heavy-duty, diesel powered, underground mining equipment and could replace expensive, complicated exhaust aftertreatment devices use, for particulate reduction.

- Verify the previous laboratory work in the field.

Status: November 1995-March 31, 1996

\section{Accomplishments:}

- Laboratory results from testing showed that SME could reduce diesel PM by reducing nonvolatile carbon soot emissions. This warranted further investigation (two-part project).

\section{Part I}

- Measured diesel PM emissions of SME and commercial, low-sulfur, No. 2 diesel fuel in a working section of an underground mine.

- 3.5 yard Wagner LHD was operated on SME.

- A decrease in black smoke and a slight decrease in power was noted for SME use.

- Reduction in diesel PM emissions through the use of SME was significant with regard to previous laboratory results, due in part to the heavier load of the LHD.

\section{Part II}

- Jeffrey 4110 Ramcar (diesel shuttle-car) was used to transport coal.

- No fuel-related operational difficulties were experienced during 200 hours of testing with each fuel.

- SME use decreased fuel-energy content by $10 \%$.

- Results were positive, and a controlled field study of SME in an underground coal mine is recommended.

Participants: National Biodiesel Board, Twin Rivers Technologies, Inc. (biodiesel supplier), Homestake Mining Company (test site), Caterpillar (diesel engine), U.S. Bureau of Mines Air Quality Division - Diesel Technology Group

Sponsoring Organization(s): National Biodiesel Board, U.S. Bureau of Mines Air Quality Division - Diesel Technology Group

Point of Contact: Ms. Bev Thessen, National Biodiesel Board, P.O. Box 104898, Jefferson City, MO, 65110-4898, phone 573.635.3893, fax 573.635.7913, e-mail biodiesel@ sockets.net.

Paper: 
McDonald, J. (1995). Field Trials of Soy Methyl Ester as a Fuel for Diesel Powered Equipment in Underground Mines, Final Two-Part Report FY 1995. (NBB \# 52015-1). Jefferson City, MO: National Biodiesel Board. 


\section{Project Title:}

Fueling Direct Injected Diesel Engines with 100\% Neat Biodiesel

Background: Much of the biodiesel research conducted since the mid-1980s in the United States has involved blending biodiesel and low-sulfur petroleum diesel fuel ranging from $10 \%$ to $100 \%$ blends. The primary goal for this research was to investigate the long-term real-world impact of fueling modem direct injected on-road diesel engines with $100 \%$ biodiesel.

\section{Objectives:}

- $\log 50,000$ miles on 5.9L No. 1 diesel engine, or until the engine has exceeded 100,000 miles of operation.

- Record engine operating parameters including fuel economy; engine oil analysis; parts replaced; and miles driven, while measuring engine power using a chassis dynamometer at 12,000-mile intervals.

- Record $\mathrm{NO}_{x}, \mathrm{CO}, \mathrm{CO}_{2}, \mathrm{HC}$ and opacity by using a NOVA portable analyzer and a Telonic Berkley opacity meter.

Status: April 14, 1995-July 31, 1996, report completed August 31, 1996.

\section{Accomplishments:}

- Fuel consumption and related maintenance costs for these engines were recorded and the engines were power-tested using a chassis dynamometer when fueled with $100 \%$ biodiesel.

- A 1991 pickup was placed into service July 1, 1995 and logged 12,000 miles.

- A 1992 pickup was placed into service July 10,1995 and logged nearly 50,000 miles.

- Engine oil samples were taken at 1,000-mile intervals for analysis. The findings suggest the engine oil is cleaner than if the engine were operated on diesel fuel. The engines were exceptionally clean and no sludge-like deposits were noted in engine.

Participants: National Biodiesel Board

\section{Sponsoring Organization(s): National Biodiesel Board}

Point of Contact: Ms. Bev Thessen, National Biodiesel Board, P.O. Box 104898, Jefferson City, MO, 65110-4898, phone 573.635.3893, fax 573.635.7913, e-mail biodiesel@ sockets.net. Leon G. Schumacher or William Wetherell, University of Missouri, 235 Agricultural Engineering Bldg., Columbia, MO 65211, phone 573.882.2126, fax 573.882.3958, e-mail leon schumacher@muccmail.missouri.edu.

Paper:

Schumacher, Leon G. and William B. Wetherell (August 1996). Fueling Direct Injected Diesel Engines with 100\% Neat Biodiesel. Jefferson City, MO: National Biodiesel Board. 


\section{Project Title:}

Identification of Elements Found in Increased Soluble Fraction of Particulate Emissions with a Methyl Soyate Blend

Background: Work previously completed by FMD on biodiesel emission research using DDC MUI and DDEC engine technology has experienced an increase in the soluble fraction portion of the PM. Compared to baseline neat diesel soluble fraction weights, B20 blends will predictably increase the amount of soluble fraction collected on the particulate filter.

\section{Objectives:}

- Perform SOF tests using the particulate filters from the $6 \mathrm{~V}-71 \mathrm{~N}$ certification engine.

- Determine the chemical makeup of the SOF of PM on B20 filters.

Status: Completed March 1995.

\section{Accomplishments:}

- The results of the testing unquestionably shows SME to be the primary factor that causes increased SOF particulate emissions. Results show it is not the lubricating oil or diesel fuel.

- Based on the completed testing FMD feels only a small portion of SME causes the increase in soluble fraction. Two point power checks and engine performance indicates that most SME is doing its job in the combustion process; reducing carbon, $\mathrm{CO}$, and THC while providing nearly equal fuel efficiency to neat petroleum-based diesel.

Participants: FMD

\section{Sponsoring Organization(s): NBB}

Point of Contact: Ms. Bev Thessen, National Biodiesel Board, P.O. Box 104898, Jefferson City, MO, 65110-4898, phone 573.635.3893, fax 573.635.7913, e-mail biodiesel@sockets.net; Dwayne Fosseen, President, Fosseen Manufacturing and Development, P.O. Box 10, Radcliffe, IA 50230, phone 515.899.2115, fax 515.899.2147.

\section{Paper:}

Identification of Elements Found in Increased Soluble Fraction of Particulate Emissions with a Methyl Soyate Blend. NBB 219-3. Jefferson City, MO: National Biodiesel Board. 
Project Title:

Life Cycle Assessment of Biodiesel

Background: There is a need to evaluate the energy, environmental, and economic characteristics of producing biodiesel in the United States from soy oil compared to petroleum diesel.

Objective: Tho quantify and compare the comprehensive sets of environmental flows (to and from the environment) associated with both biodiesel and petroleum-based diesel, over their entire life cycles.

The project has four phases:

Phase 1 - Establish approach to LCA. This phase is complete.

Phase 2 - Develop a supporting data set for LCA. This stage is undergoing finalization. Phase 3 - Conduct LCA. This stage is $90 \%$ complete.

Phase 4 - Finalize results. The project is currently in the fourth phase.

Status: FY 1995-FY 1997; Phase 4

Accomplishments:

- A Biodiesel Working Group has been established, an unprecedented collection of private, and govemment interests that includes USDA, DOE, EPA, the City of Chicago, NBB, Exxon, ARCO Chemical, Cargill, TRT, the Energy and Environmental Studies Institute, and the American Petroleum Institute.

- All data have been collected and preliminary results generated. The analysis is undergoing intemal peer review among the principal investigators. A draft peer review report will be available by late 1997, and the project will be completed within 3 months after that.

Participants: National Renewable Energy Laboratory; U.S. Department of AgricultureEconomic Research Service-Office of Energy and New Uses; Ecobalance, Inc.

Sponsoring Organization(s): U.S. Department of Energy Office of Fuels Development, U.S. Department of Agriculture-Economic Research Service-Office of Energy and New Uses

Point of Contact: Dr. K. Shaine Tyson, National Renewable Energy Laboratory, 1617 Cole Blvd., Golden, CO 80401-3393; phone 303.275.4616, fax 303.275.4675, e-mail tysonk@tcplink.nrel.gov.

\section{Papers:}

Life Cycle Assessment of Petroleum-Based Diesel Fuel and Biodiesel Forthcoming March 1998.

Coulon, R, V. Camobreco, J. Sheehan, J. Duffield (1996). "Life Cycle Assessment of Biodiesel Versus Petroleum Biodiesel Fuel." SETAC 17 Annual Meeting--Abstract Book. Partnerships for the Environment: Science, Education and Policy, Washington, DC, November 17-21. Published by Society of Environmental Toxicology and Chemistry, Pensacola, FL.

Life Cycle Assessment of Petroleum-Based Diesel Fuel and Biodiesel--Data Summary Document. July 1996. 
Life Cycle Assessment of Petroleum-Based Diesel Fuel and Biodiesel--Final Scoping Document. December 1995. 


\section{Project Title:}

Massachusetts's Possible Biodiesel Use to Meet Emission Standards for Clean Air Act Compliance

Background: The study is designed to determine how biodiesel affects air quality and to determine whether the affects are beneficial enough to the City of Boston to help with compliance of the CAA Standards.

Objectives:

- Use biodiesel in a way that is cost effective both in terms of fuel cost and air quality.

- Determine whether biodiesel would be a cost-effective way to help Boston meet air quality standards.

Status: January 1997-January 1998

\section{Accomplishments:}

- MBTA and DOER completed a study that concluded a $20 \%$ biodiesel blend is the most cost-effective option for compliance with particulate emission standards for urban buses.

- The study concluded that from 1995-2007 biodiesel is the most cost-effective option for Boston to comply with CAA regulations.

Participants: Massachusetts Bay Transit Authority and Division of Energy Resources

Sponsoring Organization(s): Massachusetts Bay Transit Authority, Executive Office of Administration and Finance, Division of Energy Resources

Point of Contact: Irving Sacks, Division of Energy Resources, 100 Cambridge Street, 15th Floor, Boston, MA 02202, phone 617.727.4732, ext. 131, fax 617.727.0030.

Paper: Final report issued in November 1997, letter of concurrence from MBTA. Decision to go forward is forthcoming. 


\section{Project Title:}

\section{Mechanisms of Emissions Reduction Using Biodiesel Fuels}

Background: This study combines the use of a three-dimensional computer model (diesel engine simulator) with experimental measurements to explain formation of $\mathrm{NO}_{\mathrm{x}}$ and the SOF of PM when using biodiesel in heavy vehicle diesel engines. This understanding should provide the basis for developing a strategy for further pollutant reductions when using biodiesel. Such a strategy might include the use of additives, changes in engine hardware or configuration, or modifications to the properties of biodiesel.

\section{Objectives:}

- Conduct engine experiments and computer simulations to study the effects of methyl soyate (biodiesel) blends with No. 2 diesel fuel under various high-pressure injections schemes on the direct-injection diesel engine performance.

- Determine and evaluate the factors controlling $\mathrm{NO}_{\mathrm{x}}$ and particulate formation.

Status: August 1995-January 1996

\section{Accomplishments:}

- Experimental test were conducted with biodiesel fuel blended in baseline No. 2 diesel fuel in concentrations of $20 \%$ and $40 \%$ by volume on a single cylinder version of a 3400 series Caterpillar DI diesel engine. A blend of $20 \%$ by volume octadecene in No. 2 diesel fuel was also investigated to determine the mechanism of emissions reduction. Using both single and multiple injection strategies, these fuel blends were compared against pure No. 2 diesel fuel's emissions and combustion characteristics.

- It was concluded that the increased $\mathrm{NO}_{x}$ observed with the use of biodiesel fuels is due to increased local temperatures because of enhanced fuel/air mixing and increased spray penetration.

- The increased spray penetration results from the higher fuel viscosity of the biodiesel blended fuels, which leads to reduced injection duration.

Participants: Army Research Office, National Biodiesel Board, and University of WisconsinMadison

\section{Sponsoring Organization(s): National Biodiesel Board}

Point of Contact: Ms. Bev Thessen, National Biodiesel Board, P.O. Box 104898, Jefferson City, MO, 65110-4898, phone 573.635.3893, fax 573.635.7913, e-mail biodiesel@sockets.net. C.Y. Choi, G.R. Bower, R.D. Retiz, University of Wisconsin-Madison, Engine Research Center, 1500 Engineering Drive, Madison WI 53706, phone 608.263.1624, fax 608.262.6707.

\section{Paper:}

"Effects of Biodiesel Blended Fuels and Multiple Injections on D.I. Diesel Engine Emissions," SAE paper 970218 , C.Y. Choi, G.R. Bower, and R.D. Retiz, University of Wisconsin, Madison, 


\section{Project Title:}

\section{Northeast Study on Large Diesel Engines}

Background: The focus of this project is a comparative analysis of pollutant and particulate emissions in a diesel engine using various blends of conventional diesel fuel and biodiesel. NRBP is interested in the air emission benefits of biodiesel because most of the region is in nonattainment for ozone and some of it is in nonattainment for particulates.

\section{Objectives:}

- Demonstrate the environmental benefits of biodiesel in a large heavy-duty diesel engine.

- It is hoped that this will encourage the production of 4 million gallons of biodiesel in the Northeast by the year 2000.

- Collect baseline data from a selected stationary diesel engine, operating with and without a catalyst, and compare it to specified combinations of biodiesel blends, with and without a catalyst, to determine if toxicity levels are reduced with biodiesel over baseline petroleum diesel.

\section{Status: FY 1997}

\section{Accomplishments:}

- The RFP has been issued for a contractor to administer the turbine engine testing. A contractor was selected and testing will begin in mid-September.

Participants: New England Power Company; Twin Rivers Technologies, Inc., and Miratech Corporation

Sponsoring Organization(s): Northeast Regional Biomass Energy Program

Point of Contact: Richard Handley, Northeast Regional Biomass Program, CONEG Policy Research Center, Inc., 400 N. Capitol St., Suite 382, Washington, DC 20001, phone 518.899.9572, fax 518.899.9574, e-mail handley@ capital.net.

Papers: Report will be available by October 1997. 


\section{Project Title:}

Optimize 20\% MethylSoyate \& Diesel Blend 1977 DDC 6V-71N Engine (Part-2)

Background: Increasingly stringent legislation on engine exhaust emission levels has resulted in research to use fuels and fuel blends to reduced emissions. Urban transit buses, which predominantly use the DDC two-stroke diesel engines, are the targets in this area of research.

Objectives:

- Rebuild the engine to original specifications based on EPA's suggestion to test a "worst case engine" for the retrofit/rebuild program.

- The research involved a 75-hour engine break-in.

- The engine was tested using the full EPA heavy duty transient test cycle to generate certification quality gaseous and particulate data on the following fuels: (a) EPA No. 2 diesel (<.05 sulfur), and (b) $20 \% / 80 \%$ SME/EPA diesel blend, referred to as B20.

- This research project was designed to conduct additional EPA transient tests generating data with the following configurations: (a) catalyst with EPA No. 2 diesel; b) catalyst with $\mathrm{B} 20$; (c) timing optimization study (retard to reduce $\mathrm{NO}_{x_{i}}$ (d) combination of catalyst and optimized timing with EPA No. 2 diesel; (e) combination of catalyst and optimized timing with $\mathrm{B} 20$; and $\mathrm{f}$ ) smoke tests on all test configurations.

Status: January 10, 1995

Accomplishments:

- The results of the rebuilt engine show reduced total particulate and total hydrocarbon by more than 50\%; $\mathrm{NO}_{x}$ increases about $17 \%$ on both EPA No. 2 diesel and B2O fuel.

- These results indicate that with the B20, emission reductions on $\mathrm{CO}$ and THC were observed; $\mathrm{NO}_{x}$ increases marginally, and $\mathrm{PM}$ is marginally reduced.

- Timing retard is sensitive on $\mathrm{NO}_{x}$ and needs to be determined precisely to achieve desired $\mathrm{NO}_{x}$ reduction, which has been demonstrated. The composition of PM is changed with the SME blends.

- A reduction in insoluble fraction is observed; SOF increases proportionally.

- A significant reduction in particulate, primarily on the SOF, is achieved with an oxidation catalyst. This catalyst also significantly reduces $\mathrm{THC}$ and $\mathrm{CO}$.

Participants: Fosseen Manufacturing and Development, ORTECH Corporation

Sponsoring Organization(s): National Biodiesel Board

Point of Contact: Ms. Bev Thessen, National Biodiesel Board, P.O. Box 104898, Jefferson City, MO, 65110-4898, phone 573.635.3893, fax 573.635.7913, e-mail biodiesel @ sockets.net. Dwayne Fosseen, Fosseen Manufacturing and Development, Ltd., PO Box 10, Radcliffe, IA 50230, phone 515.899.2115, fax 515.899.2147.

Paper:

Fosseen Manufacturing and Development. (1994). Optimize 20\% Methyl/Soyate \& Diesel Blend 1977 DDC 6V-71N Engine (Part-2). NSDB 219-2. Jefferson City, MO: National SoyDiesel Board. Work performed by Fosseen Manufacturing \& Development, Radcliffe, IA. 
Project Title:

Performance and Emission Characteristics of Tallow Ester, Ethanol and Diesel Fuel Blends in Cummins N14-410 Diesel Engine

Background: The trend toward cleaner-buming diesel fuel is growing worldwide. As the limits on exhaust emissions are imposed by EPA, industries are hard pressed to use and produce more environmentally friendly fuels. One result has been the development of renewable altemative fuels, particularly biodiesel. Biodiesel is the fuel comprised of alcohol esters derived from oils and fats from biological renewable sources. This fuel is believed to emit less of most regulated pollutants than standard diesel fuel.

\section{Objectives:}

- Evaluate biodiesel's performance and emission characteristics in a Cummins N14-410 diesel engine operating on blends of TME, ethanol, and high-sulfur No. 2 diesel fuel.

- Determine the physical properties of blends.

- Monitor engine performance, exhaust gas and emissions, and smoke of the blends compared with diesel fuel.

Status: Completed

\section{Accomplishments:}

- The $100 \%$ TME has high density and viscosity, which can be reduced by blending with ethanol in a ration of 65:35 (v:v).

- Engine performance with TME did not differ largely from that of diesel-fueled engine performance. A slight power loss combined with an increase in fuel consumption was observed with increasing TME content in diesel: TME:ethanol blends.

- CO emission decreased with corresponding increase in $\mathrm{CO}_{2}$ emissions with increase in TME content in the blend.

- There was slight increase in $\mathrm{NO}_{x}$ emissions with increasing TME content in the blends, but $\mathrm{NO}_{x}$ values were always less than the EPA requirements.

- Smoke results were inconclusive because of high variability and non-repeatability of the results.

Participants: University of Nebraska-Lincoln

Sponsoring Organization(s): University of Nebraska-Lincoln

Point of Contact: Yusef Ali, Industrial Agricultural Products Center and Department of Biological Systems Engineering, University of Nebraska-Lincoln, Lincoln, NE 68583-0730

Paper(s):

Ali, Y.; Hanna, M.A. (1994). "Performance and Emission Characteristics of Tallow Ester, Ethanol and Diesel Fuel Blends in Cummins N14-410 Diesel Engine." Proceedings of the 6th National Bioenergy Conference, vol. I, Bioenergy ‘94, Reno-Sparks, NV. Western Regional Biomass Energy Program, pp. 3-10. 
Project Title:

Soybean Oil/Diesel Fuel Blends

Background: Biodiesel's ability to reduce emissions was recognized by NSDB. The NSDB has subsequently developed a program to commercialize biodiesel as an alternative fuel. This program considered the economic factors involved with the sell of biodiesel and suggested the use of biodiesel/diesel blends to defer costs.

\section{Objectives:}

- Determine the effects of fueling a diesel engine with biodiesel/diesel fuel blends.

- Compare the engine power, EPA-regulated engine exhaust emissions, effects of adjusting timing on $\mathrm{NO}_{x}$ emissions, and EPA-regulated exhaust emissions when the engine exhaust system was equipped with a catalytic converter of biodiesel/diesel fuel blends.

Status: 1995

Accomplishments:

- Fueling with biodiesel/diesel fuel blends reduced PM, THC, and CO while increasing NOx emissions. The optimum blend of biodiesel and diesel fuel, based on the trade-off of PM decrease and $\mathrm{NO}_{x}$ increase, was a $20 \% / 80 \%$ biodiesel/diesel-fuel blend.

- Recommends engine optimization strategies should be developed that fully takes advantage of the physical and chemical makeup of biodiesel.

- Suggest additional test be conducted to evaluate other catalytic converters and the durability of these devices over time.

Participants: University of Missouri, Fosseen Manufacturing and Development, ORTECH Intemational

Sponsoring Organization(s): University of Missouri, Fosseen Manufacturing and Development, ORTECH Intemational

Point of Contact: Dr. Leon Schumacher, University of Missouri Columbia, 235 Agricultural Engineering Bldg., Columbia, MO 65211, phone 573.882.2126, fax 573.884.5650, e-mail leon schumacher@muccmail.missouri.edu.

\section{Paper(s):}

Schumacher, L.G.; Fosseen, D.; Goetz, W.; Borgelt, S.C.; Hires, W.G. (1995) "6V-92TA DDC Engine Exhaust Emission Tests Using Methyl Ester Soybean Oil/Diesel Fuel Blends" Bioresource Technology.

Schumacher, L.G.; Borgelt, S.C.; Hires, W.G; Fosseen, D.; Goetz, W. (1994) Fueling Diesel Engines with Blends of Methyl Ester Soybean Oil and Diesel Fuel. Available from http://www.missouri.edu/ pavt0689/ASAED94.htm 


\section{Project Title:}

Technology for Efficient Use of Agricultural Resources

Background: Laboratory and field investigation will take place to develop techniques for data collection, information management, and input application for optimum crop management. Biodiesel will be tested in terms of engine performance, exhaust emissions, and material compatibility.

\section{Objectives:}

- Obtain data to quantify spatial variability of land, soil, and crop properties.

- Use these data to develop methods for improved land management.

- Evaluate and develop altemative energy sources.

Status: July 1994-September 1997.

\section{Accomplishments:}

- Research efforts focus on exhaust emission characteristics and engine performance from biodiesel derived from alcohol esters of organic oils (vegetable and tallow).

Participants: Food Science and Engineering, University of Missouri

Sponsoring Organization(s): U.S. Department of Agriculture-Cooperative State Research, Education, and Extension Service, University of Missouri

Point of Contact: S.C. Borgelt, Food Science and Engineering, University of Missouri, Columbia, MO 65211, phone 573.882.7549.

\section{Papers:}

Schumacher, L.G., S.C. Borgelt, et al. (1996) "Heavy-Duty Exhaust Emission Tests Using Soydiesel/Diesel Fuel Blends." Biores. Tech. 57(l):31-36.

Schumacher, L.G., S.C. Borgelt, W.G. Ares, et al. (1996). “100,000 Miles of Fueling 5.9 L Cummins Engines with 100 Percent Biodiesel." Society of Automotive Engineers.

Proceedings, Paper No. 962233. abstract.

Schumacher, L.G., S.C. Borgelt and W.G. Hires (1995). "Fueling a Diesel Engine with Methyl Ester Soybean Oil." Applied Engineering in Agriculture 11(1):37-40.

Additional Information: CRIS Accession No.: 9166347 


\section{Project Title:}

The Effect of Biodiesel Fuel Composition on Diesel Combustion and Emissions

Background: A number of studies have shown that organic seed oils, such as soybean, safflower, rapeseed, and their esters, are viable alternative fuels for diesel engines. Extensive research has been conducted with SME, but very little research has been conducted on the combustion and emissions of the four or five pure components present in SME. Knowing which ester produces the lowest emissions could lead to selective breeding of soybeans or changes in soybean processing to produce more of the low emission compound.

\section{Objectives:}

- Evaluate the impact of biodiesel-diesel fuel blends on the exhaust emissions from a diesel engine and compare these results with the effects of oxygen enrichment of the intake air, with blends of octadecane in diesel fuel, and with cetane improver.

- Compare the performance and emission levels of the various esters present in SME.

Status: May 1996

Accomplishments:

- The CN of ester/diesel fuel blends was higher in longer chain length esters. Saturated esters increased the $\mathrm{CN}$ more than unsaturated esters.

- The solid portion of the particulate decreased by $33 \%$ and $\mathrm{NO}_{x}$ emissions increased by $25 \%$ as the oxygen content of the intake air was increased from $20.5 \%$ to $22.0 \%$

- Biodiesel particulate reducing effect was attributed to a combination of its oxygen content and its displacement of aromatic and shorter-chain HCs with long-chain esters.

- Particulate emissions were significantly reduced when the diesel engine was fueled with blends of methyl palmitate with diesel fuel.

- All the esters demonstrated a significant reduction in $\mathrm{HC}$ emissions.

Participants: lowa State University

Sponsoring Organization(s): lowa Energy Center; lowa Soybean Promotion Board

Point of Contact: Jon Van Gerpen, Mechanical Engineering Department, lowa State University, 2025 Black Engineering Bldg., Ames, IA 50011-2161, phone 515.294.5563, fax 294.3261, e-mail jvg@iastate.edu

Paper(s):

Schmidt, K; Van Gerpen, J. (1996). "The Effect of Biodiesel Fuel Composition on Diesel Combustion and Emissions." Alternative Fuel: Composition, Performance, Engines, and Systems; May 6-8, Dearbom, MI. SAE 961086. Warrendale, PA: Society of Automotive Engineers, Inc., pp. 113-124. 


\section{Project Title:}

Transient Emissions Testing of Biodiesel and Other Additives in a DDC Series 60 Engine

Background: To determine the effect of cetane improving additives in combination with biodiesel.

Objective: To evaluate several diesel fuel additives, both by themselves and in conjunction with biodiesel, in terms of their effects on diesel exhaust emissions.

Status: December 1994

\section{Accomplishments:}

- Emissions results with biodiesel blends were generally consistent with other tests.

- Emissions results using biodiesel blends with cetane improvers were mixed. Further investigation into the use of additives to improve biodiesel emissions is necessary before drawing definitive conclusions regarding their potential benefit with biodiesel blends.

Participants: Southwest Research Institute

Sponsoring Organization(s): National Biodiesel Board

Point of Contact: Christopher Sharp, Southwest Research Institute, 6220 Culebra Road, San Antonio, TX 78238-5100, phone 210.684.5111, fax 210.522.3496

Paper(s):

Sharp, C.A. (1994). "Transient Emissions Testing of Biodiesel and other Additives in a DDC Series 60 Engine. Jefferson City, MO: National Biodiesel Board. Work performed by Southwest Research Institute, San Antonio, TX. 


\section{Project Title:}

Transient Emission Evaluation of Biodiesel Fuel Blend in a 1987 Cummins L10 and DDC 6V92-TA

Background: Biodiesel is believed to reduced regulated exhaust emissions compared to conventional biodiesel. However, little quantitative research has been done to date to substantiate this belief. This project is designed to quantify the effect of biodiesel on engine exhaust emissions. To achieve this quantification, transient emission testing was performed according to EPA's procedure for certifying heavy-duty diesel engines.

Objectives:

- Evaluate the effectiveness of a $20 \%$ biodiesel blend in reducing regulated exhaust emissions using the EPA transient test cycle.

- Demonstrate the benefit of an exhaust catalyst and retarded timing in combination with the biodiesel fuel blend.

Status: November 1995

\section{Accomplishments:}

- The biodiesel blend alone improved composite transient emissions of HC, CO, and PM.

- When combined with an exhaust catalyst and timing retard, the biodiesel blend reduced all regulated emissions substantially.

Participants: Engineering Testing Service, National Biodiesel Board

Sponsoring Organization(s): National Biodiesel Board

Point of Contact: Ms. Bev Thessen, National Biodiesel Board, P.O. Box 104898, Jefferson City, MO, 65110-4898, phone 573.635.3893, fax 573.635.7913, e-mail biodiesel@ sockets.net. David Human, Engineering Testing Services, 4500 Leeds Avenue, Charleston, SC 29405, phone 803.745.1483, fax 803.745.1442.

Paper(s):

Stotler, R.W.; Human, D.M. (1995). Transient Emission Evaluation of Biodiesel Fuel Blend in a 1987 Cummins L10 and DDC 6V-92-TA. Project \# 55495001. Charleston, SC: Engineering Test Services 
Project Title:

Transient Emissions from No. 2 Diesel and Biodiesel Blends in a DDC Series 60 Engine

Background: Oxygenated fuels have a history of reducing exhaust emissions from motor vehicles. Additions of MTBE and ethanol have shown success in reducing emissions from gasoline engines. The success of oxygenated gasoline has sparked interest in the use of oxygenated compounds as emissions reducing additives in diesel fuel.

Objective: To investigate the effect of blending biodiesel with a base diesel fuel on emissions from a DDC Series 60 engine.

Status: May 1996

Accomplishments:

- As the percentage of biodiesel increased, the $\mathrm{NO}_{\mathrm{x}}$ emission increased; THC, CO, and PM decreased.

- Reductions in aromatic content or increases in cetane number could lead to $\mathrm{NO}_{\mathrm{x}}$ neutral diesel/biodiesel blends as compared to certification diesel fuel.

- At the $35 \%$ level, the particulate reduction is large enough to offer significant emission benefits to fleet operators at little or no $\mathrm{NO}_{x}$ penalty.

Participants: Colorado Institute for Fuels and High-Altitude Engine Research and NREL

Sponsoring Organization(s): DOE Office of Transportation Technologies

Point of Contact: Michael Graboski, Colorado School of Mines, Colorado Institute for Fuels and Engine Research, Golden, CO 80401, phone 303.273.3246 or 303.299.3143, fax 303.299.3142

Paper(s):

Graboski, M.S.; Ross, J.D.; McCormick, R.L. (1996). “Transient Emissions from No. 2 Diesel and Biodiesel Blends in a DDC Series 60 Engine." Diesel Engine Combustion and Emission Characteristics; May 6-8, 1996, Dearbom, MI. SAE 96116. Warrendale, PA: Society of Automotive Engineers, Inc., pp. 55-62. 


\section{B. Durability \& Maintenance}

Also see the following projects:

Biofuels Research

Error! Reference source not found.

Hydrogenated Soy Ethyl Ester (HySEE) Production and Engine Durability Test Project

Industrial Agricultural Products Center

Over-the-Road Heavy-Duty Diesel Engine Operational Demonstration

Thermal and Oxidative Stability 


\section{Project Title:}

Biodiesel: A Partial Substitute for Diesel in Transit Buses

Background: Biodiesel fuels are particularly attractive for environmental niche markets such as air quality nonattainment areas and delicate ecosystems because of the potential for lowered emissions, low toxicity, and biodegradability. However, to be attractive as an altemative fuel, diesel engines must be able to use biodiesel with minimal modifications and must not suffer in terms of engine performance or engine life.

\section{Objectives:}

- Test the compatibility of biodiesel with fuel system components used in the bus fleet. OEM engineers will determine and report for examination the physical and chemical properties of the 80/20 blend. Injector deposits will be evaluated on a Cummins $94 \mathrm{M} 11$ diesel engine.

- Evaluate the performance of a DDC 6V-92TA for a 1,000-hour durability test.

Status: Project scheduled to be completed in August 1997.

Accomplishments: Will be detailed in final project report.

Participants: Fosseen Manufacturing and Development

Sponsoring Organization(s): U.S. Department of Agriculture-Cooperative State Research, Education, and Extension Service

Point of Contact: Dwayne Fossen, Fossen Manufacturing and Development, P.O. Box 10, Radcliffe, IA, phone 515.899.2115

Papers: None available at this time. 


\section{Project Title:}

Biodiesel Injector Deposit Evaluation Test

Background: To investigate the potential of biodiesel to be used as injector deposit reducing compound.

\section{Objectives:}

- Investigate the detergency effects of biodiesel on diesel engines.

- Test injectors by installing new injectors at the beginning of each test (objective tests including baseline fuel, neat biodiesel No.1, diesel No. 2 LS diesel, and $20 \%$ blends of biodiesel. The overall objective was to keep the injectors clean throughout the 125 test hours.)

- Run the tests with a commercial deposit-control additive to determine whether the tests using biodiesel have a deleterious effect on the plunger deposit formation.

Status: August 1, 1995-September 30, 1997

\section{Accomplishments:}

- The testing was completed on two Cummins 1988 L10 Engines joined in tandem. The test runs for 125 hours on a cycle that altemates between driving and motoring of each engine. The pass/fail criteria for this test are based on carbon and lacquer deposits (CRC rating) on the injector plunger, as well as flow loss specification of the complete injector.

- Based on the results from the Cummins L10 Injectors Depositing Test, the use of $20 \%$ biodiesel blended with various petrodiesel fuels increases injector deposits. However, adding commercially available detergency additive can reduce the deposit formation to the equivalent level experienced with neat petrodiesel. Further testing is required to procure an additive that can be blended with the petrodiesel and biodiesel mixture to reduce deposits levels to within the passing range on the L10 Injector Depositing Test.

Participants: Engineering Test Services and University of Missouri-Columbia

Sponsoring Organization(s): National Biodiesel Board, U.S. Department of Energy, and United Soybean Board

Point of Contact: Steve Howell, MARC-IV Consulting, Inc, 16200 Northridge Road, Keamey, $\mathrm{MO}, 64060$, phone 816.635.5772, fax 816.635.4836, e-mail showell@ marciv.com

Paper: Intemal National Biodiesel Board report anly 


\section{Project Title:}

Diesel Fuel Pump Evaluation and Analysis.

Background: To determine the effect of the acid value of biodiesel in the operation of fueling systems with biodiesel blends.

Objective: To characterize the operation and performance of diesel fueling systems and transfer pumps, with laboratory type pump stand apparatus, using biodiesel blends (20\% through $100 \%$ ) and $100 \%$ petrodiesel. Performance degradation that occurs with time will also be determined.

Status: August, 1995-extended until March 31, 1997.

Accomplishments:

- This project has been slowed down by the construction of the test pump stands.

- Testing has now begun and interim reports follow. Status reports are being received regularty

Participants: National Biodiesel Board, Williams Pipeline Company, System Lab Services.

Sponsoring Organization(s): National Biodiesel Board, United Soybean Board

Point of Contact: Rod Lawrence, System Lab Services, 401 East Donovan Road Kansas City, KS 66115.

Paper: 


\section{Project Title:}

\section{Overview of 1000 Hour Durability Testing DDC 6V-92TA DDCII Engine}

Background: Full commercialization of biodiesel requires further information on engine emissions, fuel systems compatibility and engine durability. EMA expressed the need for durability testing of engines under conditions that were consistent with the testing methods that they use when evaluating diesel engine durability.

\section{Objectives:}

- Conduct a 1,000-hour durability test on a 6V92-TA DDCII engine while fueling the engine with a $20 \% / 80 \%$ biodiesel/diesel blend (B20).

- Monitor engine performance.

- Document the wear that resulted during the test.

Status: Completed July 1995

Accomplishments:

- The researchers evaluated the engine durability performance operating with the same DDEC calibration adjustments and on the same B20 blend as had been used in transient emission testing previously conducted.

- Testing ceased after about 750 hours of operation because of degradation in emissions and engine performance.

- Subsequent investigation found the acid value of the fuel was above the specification; and the fueling system, used in the test, contained copper and galvanized piping which are unsuitable for biodiesel use.

- The B20 fueling did not impede the ability of the engine lubricating oil to protect the wear surfaces such as the main connecting rod and piston that appeared in excellent condition upon observation.

Participants: Detroit Diesel Corporation, Fosseen Manufacturing and Development, National Biodiesel Board, ORTECH, and University of Missouri-Columbia

\section{Sponsoring Organization(s): NBB}

Point of Contact: Ms. Bev Thessen, National Biodiesel Board, P.O. Box 104898, Jefferson Citỹ, MO, 65110-4898, phone 573.635.3893, fax 573.635.7913, e-mail biodiesel@ sockets.net.

\section{Paper:}

Schumacher, L. (1995). Overview of 1000 Hour Durability Testing DDC 6V-92TA DDC II Engine. Jefferson City, MO: National Biodiesel Board. 
Project Title:

Performance of Biodiesel-Fueled Engines

Background: The evaluation of biodiesel-fueled engines for generating electricity will be done with slow speed diesel engines commonly used by the electric utility industry. These engines will be operated continuously and at varying loads. Experiments will evaluate engine wear and long-term performance. Fuel consumption will be continuously measured by fuel transducers. Plans are to measure emissions and determine the effects of partial loading $\mathrm{NO}_{\mathbf{x}}, \mathrm{CO}, \mathrm{CO}_{2}$, $\mathrm{HC}$, and PM emissions. Long-term performance and durability will also be examined at routine service intervals of $5,000,10,000$, etc. run hours. During these routine examinations of the engines, they will be analyzed for wear and lubrication efficiency. Measurements made will include, injector tests, compressions tests, cold and hot oil pressure, and visual inspection of upper engine and cylinder walls.

\section{Objectives:}

- Determine the performance (fuel consumption, power, speed regulation, etc.) of biodieselfueled engines for electrical generation used in remote areas.

- Measure the emissions of prime power diesels when operating at variable loads and fueled with biodiesel.

- Determine the level of wear of prime power diesel engines when fueled by biodiesel and operated at variable loads.

Status: February 1995-April 1997.

\section{Accomplishments:}

- The fuel was described as being substandard because the total glycerin content was nearly $1.5 \%$ by weight, or about three times higher than acceptable. We are working with NBB, sponsors of this project and original suppliers of the fuel, to replace the unacceptable biodiesel.

- Construction of the wind/hybrid test system is nearing completion and will enable us to start testing the biodiesel fuel during the fall of 1997, if acceptable fuel is available.

Participants: U.S. Department of Agriculture-Agricultural Research Service

Sponsoring Organization(s): U.S. Department of Agriculture-Agricultural Research Service, Bushland, TX

Point of Contact: R. Nolan Clark, Agricultural Research Services, Bushland, TX, phone 806.336.5734.

Papers: None available at this time.

Additional Information: CRIS Accession No.: 9149550. 


\section{Project Title:}

Performance and Emissions of Vegetable Oil Hybrid Fuels

Background: Vegetable oils modified to provide low emission biodiesel fuels with improved viscosity, surface tension, combustion, and low temperature characteristics will be evaluated for engine performance. Promising fuels will be tested with a direct-injection engine for endurance, performance, emissions and particulates characteristics. Short-term engine tests for durability effects of altemative diesel fuels will be developed to provide timely and cost efficient screening of vegetable oil-based hybrid formulations.

Objectives: Investigate effects of compression and other properties of vegetable oil hybrid fuels on performance characteristics and emissions in direct-injection engines.

Status: Project was initiated in August 1992 and is scheduled to be completed by August 1997

Accomplishments:

- Erosion in the water spray chamber halted a shakedown test. Gravity loops were installed to halt the problem.

- Shakedown runs showed good mechanical performance under atmospheric conditions.

- Subatmospheric testing produced plugging of the Roots blower filter by particulates. This problem may be solved by exchanging the filter with a large farm tractor filter or removing it altogether.

Participants: U.S. Department of Agriculture-Agricultural Research Service National Center for Agricultural Utilization Research, University of Illinois

Sponsoring Organization(s): U.S. Department of Agriculture-Agricultural Research Service, National Center for Agricultural Utilization Research

Point of Contact: Robert Dunn, USDA-ARS, National Center for Agricultural Utilization Research, 1815 N. University Street, Peoria, IL 61604, phone 309.681.6413, fax 309.681.6686, e-mail dunnro@mail.ncaur.usda.gov

Paper(s): None available at this time.

Additional Information: ARS Project No. 3620-41000=075-01S; CRIS accession \#9146887 


\section{Project Title:}

\section{Production and Testing of Ethyl and Methyl Esters Part II}

Background: This project was the second phase of the project initiated in 1993. It was designed to evaluate the physical and chemical properties of methyl and ethyl esters produced from a variety of feedstocks as well as short-term engine performance.

\section{Objectives:}

- Produce sufficient quantities of ethyl and methyl esters of rapeseed, soybean, canola, and tallow oils--using the procedures developed in Part I--for conducting 200-hour EMA test cycles.

- Conduct EMA test cycles in three-cylinder direct injection engines, fueling the engines with $100 \%$ of the test fuels.

Status: January 1, 1994-December 31, 1994

\section{Accomplishments:}

- 150 hours were logged on the John Deere diesel engine.

- $2,250 \mathrm{~L}$ of fuel were consumed during the performance testing.

- Physical and chemical properties of the esters were determined.

- Biodiesel fuels (a) contained lower gross heat content that petrodiesel; (b) produced slightly lower horsepower and torque; and (c) produced slightly higher fuel consumption.

- Viscosities and cloud points of the esters were higher than petrodiesel.

- The physical and chemical properties of the methyl and ethyl esters were similar.

Participants: Midwest Biofuels (methyl ester of soybean oil), NBB; PN\&A RBEP; Phillips 66 (low sulfur diesel fuel); and University of Idaho, Department of Agricultural Engineering

Sponsoring Organization(s): National Biodiesel Board and Pacific Northwest and Alaska Regional Biomass Energy Program

Point of Contact: Ms. Bev Thessen, National Biodiesel Board, P.O. Box 104898, Jefferson City, MO, 65110-4898, phone 573.635.3893, fax 573.635.7913, e-mail biodiesel@sockets.net. Charles L. Peterson, University of Idaho, Department of Agricultural Engineering, Moscow, ID 83844, phone 208.885.7906, fax 208.885.8923, e-mail peterson@ novell.uidaho.edu.

\section{Paper:}

Production and Testing of Ethyl and Methyl Esters, Final Report for Contract Number 236-1. (National Biodiesel Board Research Programs and Projects \# 52016-1). Jefferson City, MO: National Biodiesel Board. 


\section{Project Title:}

Sample Analysis from Biodiesel Test

Background: The purpose of this project is to analyze samples of biodiesel taken during 1000-hour durability test.

\section{Objectives:}

- Analyze the biodiesel fuel used in previous durability testing with a DDC engine.

- Determine the causes of poor engine performance in the test after 750 hours of operation.

Status: 1997

\section{Accomplishments:}

- The biodiesel used was analyzed and found to be out of specification.

- Problems do not appear to be caused by glycerin.

- Copper and galvanized piping in the fueling system exacerbated the problems.

- Further investigation into acid value is recommended.

Participants: National Biodiesel Board; University of Missouri-Columbia.

Sponsoring Organization(s): National Biodiesel Board and the United Soybean Board.

Point of Contact: Ms. Bev Thessen, National Biodiesel Board, P.O. Box 104898, Jefferson

City, MO, 65110-4898, phone 573.635.3893, fax 573.635.7913, e-mail biodiesel@ sockets.net.

Paper: Under review at this time.

(Also see "Overview of 1000 Hour Durability Testing DDC 6V-92TA DDCII Engine".) 


\section{Regulatory and Legislative Activities}

\section{A. Federal Projects}

Also see the following projects:

Marine Biodiesel and Education Project for San Francisco Bay and Northem California 


\section{Project Title:}

\section{Petition for Rulemaking Under 10 CFR Part 490}

Background: To designate any and all blends of at least $20 \%$ biodiesel with petroleum diesel fuel as an alternative fuel under all generally applicable sections of 10 CFR Part 490, 420, 450 , and 451 as well as any other applicable sections of EPAct over which DOE has jurisdiction and authority.

\section{Objectives:}

- Generate a petition for submission to DOE.

- Solicit industry endorsements before submitting the petition to DOE.

- Maintain dialogue with key DOE personnel to monitor the department's progress.

- Maintain dialogue with signatories as to the status of the petition.

Status: August 1, 1995-September 30, 1997

\section{Accomplishments:}

- A petition was submitted with endorsement of more than 20 signatories.

- DOE and petition signatories held preliminary discussions regarding the petition. However, no official determination has been made by the department.

Participants: American Soybean Association, National Biodiesel Board, and other sponsors of the petition

Sponsoring Organization(s): American Soybean Association and National Biodiesel Board

Point of Contact: Ms. Bev Thessen, National Biodiesel Board, P.O. Box 104898, Jefferson City, MO, 65110-4898, phone 573.635.3893, fax 573.635.7913, e-mail biodiesel @ sockets.net. Leroy Watson, National Biodiesel Board, 3800 Pomell Lane, Suite 804, Falls Church, VA, 22041.

Paper:

Watson, L.A. (1996). Petition for Rulemaking under 10 CFR Part 490. September. Gordley Associates prepared for National Biodiesel Board. 


\section{Project Title:}

Commercialization Prospects for Biodiesel

Background: NBB and ASA formed a joint task force to review current and proposed federal laws and regulations that directly affect the commercialization prospects for biodiesel. The theme of this exercise has been to determine the best way to aid the development of the biodiesel industry.

Objectives: Create a document that:

- Contains enough information for task force members and other interested parties to make informed decisions about current and proposed laws and regulations and their impact on biodiesel.

- Focuses its attention on issues that can be legitimately and effectively addressed on either regulatory or legislative levels.

Status: February 1997

Accomplishments:

- Compliance with certain laws and regulations is critical to the successful commercialization of biodiesel. These include the CAA's definition of "substantially similar" to diesel fuel and having a market-acceptable blend of biodiesel qualify as an EPAct altemative fuel.

- The task force gives second priority to addressing the EPAct issues that demonstrate an open govemment bias against altemative fuels in favor of dedicated altemative fuel vehicles.

- The development of biodiesel vehicles will need to be addressed at the regulatory level in partnership with potential vehicle manufacturers and converters.

Participants: National Biodiesel Board/American Soybean Association Joint Task Force

Sponsoring Organization(s): National Biodiesel Board and American Soybean Association

Point of Contact: Ms. Bev Thessen, National Biodiesel Board, P.O. Box 104898, Jefferson City, MO, 65110, phone 573.635.3893, fax 573.635.7913, e-mail biodiesel@ sockets.net. Mark Sagrans, 1000 Connecticut Avenue, NW, Washington, DC 20036; phone 202.331.7373, email msagrans@ clark.net.

Paper(s):

Sagrans, M.E. (1997). Commercialization Prospects for Biodiesel. Jefferson City, MO: National Biodiesel Board. Work performed by the National Biodiesel Board/American Soybean Association Joint Task Force. 


\section{Project Title:}

Congressional Research on Biodiesel Fuel

Background: For some 15 years, there has been a national policy to foster the use of domestically produced renewable resources as a source for transportation fuels. For the past 5 years, Congress has been putting in place additional policies designed at least in part to further reduce U.S. dependence on gasoline and diesel fuel.

\section{Objectives:}

- Explain the commercialization prospects for biodiesel.

- Determine whether it is cost competitive as an EPAct alternative fuel.

Status: December 1993

\section{Accomplishments:}

- Suggest that biodiesel be accorded a tax break similar to that of ethanol until technology allows for lower prices.

- The policy issue is the role of the federal government in bridging the cost gap and in developing the necessary technology.

Participants: Congressional Research Service, The Library of Congress

Sponsoring Organization(s): Congressional Research Service, The Library of Congress

Point of Contact: Maura K. Flechtner, Research Assistant, Library of Congress, Congressional Research Service, 101 Independence Avenue, SE, Washington, DC 205400002, phone 202.707.0002, fax 202.707.5844

\section{Paper(s):}

Flechtner, M.K.; Gushee, D.E. (1993). Biodiesel Fuel: What Is It? Can It Compete? CRS Report for Congress 93-1027 S. Washington, DC: Congressional Research Service, The Library of Congress. 


\section{Project Title:}

Fuels and Fuel Additives Registration Regulations

Background: This rule, finalized in May 1994, establishes new requirements for the registration of designated F/FA as authorized by sections 211 (b) (2) and 211 (e) of CAA. Manufacturers of gasoline and diesel fuels and additives for on-road use are affected by the rule. For current fuels and additives, testing must be performed to retain registration. For new fuels and additives, testing must be completed before they are introduced into commerce.

Objectives: The purpose of the rule is to determine the potential adverse health effects of F/FA exhaust and evaporative missions. The rule will also evaluate the effects of inhalation exposure and evaporative emissions and evaluate the effects of inhalation exposure to the whole complex of emission mixtures, not the toxicology of individual pure compounds. The registration requirements are organized within a three-tier structure as follows:

- Tier 1 requires F/FA manufacturers to perform a literature search on the health and welfare effects of F/FA emissions, characterize emissions, and provide qualitative exposure information.

- Tier 2 requires biological testing for the examination of subchronic systemic and organ toxicity, as well as the assessment of specific health effects endpoints.

- When necessary, Tier 3, which includes follow-up studies or other additional tests, may be required.

The rule permits adequate test data to be submitted in lieu of conducting new duplicative tests. It also includes special provision for small businesses and certain types of products, and a group system, which permits manufacturers of similar F/FA products to share the costs of compliance.

Status: The deadline for Tier 1 submission and Tier 2 contract for biodiesel was extended to March 17, 1998.

Accomplishments:

There have been recent adjustments in the rule conceming biodiesel as follows:

- Originally, the rule envisioned separate testing groups for esters derived from plant origin and from animal origin. In the March, 1997 adjustments, EPA adopted the approach suggested by the biodiesel industry that these two groups are compositionally similar enough to be treated as one.

- EPA also adopted the biodiesel industry's recommendation to test at the $100 \%$ level.

Participants: The biodiesel industry (will be involved in the F/FA testing) and the U.S. Environmental Protection Agency

Sponsoring Organization(s): U.S. Environmental Protection Agency

Point of Contact: Joe Spata, Office of Mobile Sources, U.S. EPA, Mail Code 6406J, 401 M Street, NW, Washington, DC 20460, phone 202.233.9034

\section{Paper(s):}

The record for this rulemaking is contained in Docket No. A-90-07. The docket is located at the Air Docket, Room M-1500, 401 M Street, SW, Washington, DC 20460, phone 202.260.7548 or 202.260.7549, fax 202.260.4000. 
Kortum, David (1996). "Summary of the New Fuel and Fuel Additive Registration Regulations." Presented at the Second Workshop - Commercialization of Biodiesel: Environmental and Health Benefits." Mammoth Hot Springs, WY.

"Meeting Today's Needs for the Environment--Biodiesel and the Clean Air Act." Presented at the Third Workshop--Commercialization of Biodiesel: Producing a Quality Fuel. Boise, ID. 


\section{Project Title:}

Manufacturing Incentives for Altemative Fuel Vehicles

Background: In order for vehicles operating on biodiesel or biodiesel blends to receive the CAFE incentives, NHTSA would have to recognize biodiesel and blends of biodiesel as an approved altemative fuel. This project provides a mechanism to integrate biodiesel in the CAFE credit program.

\section{Objectives:}

- Incorporate biodiesel in the list of the NHTSA approved altemative fuels

- Include flexible fuel AFVs within the MIAFV program.

- Investigate other options available to the industry.

Status: August 1,1995-September 30, 1996.

Accomplishments:

- Work in progress

Participants: National Biodiesel Board, National Highway Transportation and Safety Association

\section{Sponsoring Organization(s): NBB}

Point of Contact: Ms. Bev Thessen, National Biodiesel Board, P.O. Box 104898, Jefferson City, MO, 65110-4898, phone 573.635.3893, fax 573.635.7913, e-mail biodiesel@ sockets.net.

\section{Paper:}

Gay, James. 1996 Manufacturing Incentives for Altemative Fuel Vehicles. National Biodiesel Board. 


\section{B. State Projects}


Project Title:

Summary of State Alternative Fuel Programs, Requirements, and Opportunities for Biodiesel

Background: This project evaluated state laws and regulations regarding altemative fuels and informed appropriate groups and individuals on how biodiesel could fit into their alternative fuel plans.

Objectives: Provide NBB with:

- Current state activities as these activities relate to altemative fuels, incentives, and other policies that may favor biodiesel.

- A series of recommendations for the industry that could be implemented at the state level.

Status: October 4, 1993

Accomplishments:

- The project identified four biodiesel industry priorities and suggested that each state consider the following recommendations for growing the biodiesel industry.

- Biodiesel can be a solution for states to comply with federal environmental and energy mandates.

- State laws and regulations can be modified to further support biodiesel use and growth.

- States currently producing biodiesel feedstocks should be encouraged to consider adoption of production incentives in an attempt to defray initial start-up costs of biodiesel production.

- High profile projects and demonstrations should be raised in order to gain more interest and support for biodiesel investments, projects, and use.

Participants: American Biofuels Association and Information Resources, Inc.

Sponsoring Organization(s): National Biodiesel Board

Point of Contact: Ms. Bev Thessen, National Biodiesel Board, P.O. Box 104898, Jefferson

City, MO, 65110-4898, phone 573.635.3893, fax 573.635.7913, e-mail biodiesel @ sockets.net.

\section{Paper:}

Information Resources, Inc. (1993). Summary of State Altemative Fuel Programs, Requirements, and Opportunities for Biodiesel. 4701-1. Jefferson City, MO: National SoyDiesel Development Board. Work performed by Information Resources, Inc., Arlington, VA. 


\section{Commercialization Activities}

\section{A. Demonstrations}

Also see the following projects:

Biodiesel Awareness and Attitudes by Transit System Managers

Multifeedstock Biodiesel Project

Rapeseed Oil as a Fuel for Agriculture 
Project Title:

1997 FutureCar Challenge

Background: The FutureCar Challenge is a 2-year competition that challenges student teams from universities in North America to design and build a mid-size family sedan capable of achieving up to 80 miles per gallon. Students blend raw materials and creative engineering to modify today's production vehicles to run on one of several "high-tech" altemative power trains and fuels. Lawrence Institute for Technology in Southfield, Michigan has entered a parallel hybrid electric vehicle using a Volkswagen 1.9-L turbo-charged, direct injection compression ignition engine, which will use B-20 supplied by TRT. Ohio State University has also developed a parallel hybrid vehicle for the FutureCar Challenge. The design is based on the Chevrolet Lumina and employs a state-of-the-art (43\% peak efficiency) 1.9- $L$ turbo-charged, direct-injection compression ignition engine along with a $10 \mathrm{~kW}$ brushless DC electric machine. This is the first year in which biodiesel is being used by some of the participants. In all, there are 12 vehicles entering the competition from 12 universities.

Objectives: To design a hybrid car that runs on biodiesel and to introduce students to the fuel.

\section{Status: FY 1996-FY 1997}

Accomplishments:

- At Lawrence Tech, work has begun on undertaking various engine modifications to reduce NOx emissions. The team is using a Ford Taurus.

- The Ohio State team is working on transforming a 1996 Chevrolet Lumina into a highly energy-efficient automobile while preserving the desirable attributes of the mid-sized sedan.

- The event is scheduled to take place June 3-11, 1997. The competition will initially begin in Warren, Michigan in June, 1997 at the GM Tech Center for emission testing. The "endurance event" will involve the cars travelling from Detroit, Michigan to Washington, DC.

Participants: Lawrence Institute for Technology, Ohio State University

Sponsoring Organization(s): DOE and USCAR--a research venture of Chrysler Corp., Ford Motor Co., and General Motors Corp. The FutureCar Challenge is under the much broader umbrella of the Partnership for a New Generation of Vehicles, a unique collaboration between USCAR and eight other agencies of the federal govemment.

Point of Contact: Lawrence Institute for Technology: Professors Greg Davis and Nicholas Brancik, Mechanical Engineering Department, phone 810.204.2563 (Davis) and 810.204.2567 (Brancik); Ohio State University: Faculty Adviser, Georgio Rizzoni, phone 614.292.3331 and Student Team Leader, Nigel Janes, phone 614.267.0015; Argonne National Laboratory: Mike Duova, 9700 S. Cass Bldg., 362, Argonne, IL 60439, phone 630.252.6398, fax 630.252.6393. and Shelley Launey, Office of Advanced Automotive Technology, U.S. Department of Energy, phone 202.586.1573; and Twin Rivers Technologies, Inc., 780 Washington Street, Quincy, MA 02166, phone 617.745.4204.

\section{Papers:}


Swan, James, et al. (1997). Design and Development of Hyades, a Parallel Hybrid Electric Vehicle for the 1997 FutureCar Challenge. Lawrence Technological University, College of Engineering, Submitted to Argonne National Laboratory.

Baumann, Bernd M. (1997). The 1997 Ohio State University Future Car. The Ohio State University, Center for Automotive Research. Submitted to Argonne National Laboratory. 


\section{Project Title:}

Biodiesel Demonstrations: Public Transit Systems and lowa Department of Transportation Heavy Duty Vehicle

Background: The 1994 lowa Legislature directed the IDOT Project to conduct a biodiesel demonstration with trucks operated by IDOT and appropriated funding to the lowa Department of Agriculture and Land Stewardship's Office of Renewable Fuels and Co-Products to fund public transit demonstration projects using biodiesel.

Objective: To test biodiesel in demonstrations involving three public transit systems which met the following criteria (determined by the lowa Soybean Promotion Board) to effectively demonstrate advantages and disadvantages of biodiesel in public transit:

- Diesel powered

- Appropriately sized fleet

- Proximity to technical support

- Appropriate fueling capabilities

- Other promotional considerations.

Status: February 3, 1995-June 21, 1995

Accomplishments:

- The IDOT evaluations in the demonstrations included a summary of findings and recommendations in regard to:

- Frequency and type of repairs on vehicles

- Comments of persons operating the vehicles

- Comments of persons maintaining the vehicles

Participants: lowa Department of Transportation, Office of Renewable Fuels and CoProducts, Fosseen Manufacturing \& Development Ltd., Boone lowa Maintenance Garage, Ames Transit Agency, Black Hawk County, and Metropolitan Transit Authority

Sponsoring Organization(s): Black Hawk County and Metropolitan Transit Authority, FMD

Point of Contact: Richard Evans, Fosseen Manufacturing \& Development, 206 May, PO Box 10, Radcliffe, lowa 50230-0010, phone 515.899.2115, fax 515.849.2147; Walter Stephenson, MET, General Manager, 1515 Blackhawk Street, Waterloo, IA 50702, phone 319.234.5714.

\section{Paper:}

October 1996; Final Report issued by the Public Transit Systems and lowa Department of Transportation Heavy Duty Vehicle. 


\section{Project Title:}

Biodiesel Fuel Evaluation for the U.S. Army Tactical Wheeled Vehicles

\section{Background:}

\section{Objectives:}

- Collect data in order to evaluate the relative performance of a 80/20 JP-8/biodiesel fuel mixture when compared to $100 \%$ JP-8 and DF-2 fuels in different wheeled vehicle systems.

- Accrue endurance mileage while operating with $80 / 20 \mathrm{JP}-8 /$ Bio-diesel fuel mixture on different vehicle engines and fuel systems so any failures modes related to the use of the biodiesel fuel mixture can be measured.

Status: April 1995

Accomplishments:

- The opacity readings for the vehicles decreased after the biodiesel blend was introduced.

- The acceleration subtest performed on a portion of the vehicles showed equal or improved acceleration when using biodiesel fuel.

- Overall, the acceleration times for all of the vehicles tested to a common maximum speed worsened when the biodiesel blend is used.

Participants: U.S. Army, Material Test Directorate, U.S. Army Tank-Automotive and Armaments Command, U.S. Army Test and Evaluation Command

Sponsoring Organization(s): U.S. Army Tank-Automotive and Armaments Command, U.S. Army Test and Evaluation Command

Point of Contact: Wayne Lucas, Material Test Directorate U.S. Army; U.S. Army Proving Ground, Yuma, AZ

\section{Paper:}

Lucas, W. (1995). Biodiesel Fuel Evaluation for the U.S. Army Tactical Wheeled Vehicles. IEG-095-000-028. Warren, MI: U.S. Amy Tank-Automotive Command. Work performed by Material Test Directorate, U.S. Army Yuma Proving Ground, Yuma, AZ. 
Project Title:

Biodiesel Fuels Demonstration During the 1996 Olympics

Background: The idea behind this project was to give intemational recognition to biodiesel use. Promotion of biodiesel would reduce imported oil dependence, add to the domestic economy, and reduce environmental pollution.

Objective: To demonstrate a biodiesel-fueled public bus during the Olympics in Atlanta, Georgia. The City of Athens, Georgia provided a full-sized diesel powered city bus and fuel dispensing facilities. The University of Georgia provided a fuel blending system, maintained the buses and kept records on their performance and operation. SERBEP provided the fuel, transfer pumps, and a storage tank for the biodiesel.

Status: January 1- December 31, 1996. Buses ran May through November.

Accomplishments:

- Biodiesel was successfully demonstrated in buses during the Summer Olympics in Atlanta.

Participants: University of Georgia's Research Foundation, City of Athens, Southeast

Regional Biomass Energy Program

Sponsoring Organization(s): Southest Regional Biomass Energy Program

Point of Contact: John Goodrum, University of Georgia, Biological \& Agricultural Engineering Department, Driftmier Center, Athens, GA 30602, phone 706.542.0867, fax 706.542.8806, email jgoodrum@gamma.bae.uga.edu.

Papers:

Goodrum, J.W. and J. Sellers (1996). Final Contract Report: Biodiesel Fuels Demonstration During the 1996 Olympics in Athens, Georgial University of Georgia. University of Georgia, Athens, GA. Available from Southeast Regional Biomass Energy Program. 


\section{Project Title:}

Biodiesel Research, Development and Demonstration Support

Background: This resource commitment was driven by the need to expand support for general biodiesel research. This project meets the need of providing consistent technical and analytical capabilities and support to on-going biodiesel development work.

\section{Objectives:}

- Expand both technical support and analytical testing capability to meet technical development requirements for researching biodiesel.

- The laboratory equipment and technical capability funded under this grant focuses on expanding the University of Idaho's Department of Biological and Agricultural Engineering technical and analytical support to further their biodiesel research, demonstration, and fuel testing activities.

Status: FY 1994-present

Accomplishments:

- The testing and acquisition of laboratory equipment has been ongoing since September 1996.

Participants: University of Idaho, Pacific Northwest and Alaska Regional Biomass Energy Program

Sponsoring Organization(s): Pacific Northwest and Alaska Regional Biomass Energy Program

Point of Contact: Dr. Charles L. Peterson, Department of Agricultural Engineering, University of Idaho, Moscow, ID 83844, phone 208.885.7906, fax 208.885.8923, e-mail peterson@novell.uidaho.edu.

\section{Papers:}

Peterson, C. (1997). The Annual Report for Biodiesel Research, Development, and Demonstration Support. 


\section{Project Title:}

Biomass-Derived Alternatives in High Performance Snowmobile Engines: A Snowmobile in the Park

Background: The project will provide detailed data on bio-based fuel options to reduce pollution and smoke caused by snowmobiles in Yellowstone National Park.

Objective: To demonstrate bio-based fuel options in snowmobiles. Emissions tests of snowmobile engines will use biomass-derived fuel and lubrication oils in two common types of engines and compare the results to those from conventionally fueled and lubricated engines.

\section{Status: FY 1995-FY 1998}

\section{Accomplishments:}

- Detailing of the test plan; obtaining and reviewing the test cycle approved by the industry; identifying concems from all participants; and identifying candidate fuels and lube oils between June 1995 and January 1996.

- Delivering fuels, lubes and engines to the laboratory and conducting emission tests at SwRI using the industry-approved test cycle between February and August 1996.

- Complete the field demonstrations of bio-based options and present report results to all the participants between June and August 1998.

- The complete analysis, reporting, and information dissemination will be sent out by September 1998.

Participants: Montana Department of Environmental Quality, Pacific Northwest and Alaska Regional Biomass Energy Program, U.S. Department of Energy Clean Cities Program, U.S. Department of the Interior's National Park Service, International Snowmobile Manufacturers Association, CONOCO Inc., West Yellowstone Chamber of Commerce, Wyoming Department of Commerce.

Sponsoring Organization(s): Pacific Northwest and Alaska Regional Biomass Energy Program

Point of Contact: Howard Haines, Department of Environmental Quality, P.O. Box 200901, Helena, MT 59620-0901, phone 406.444.6773, fax 406.444.1804, e-mail hhaines @ mt.gov

\section{Papers:}

Haines, H. (1995). Snowmobiles in Yellowstone: Biomass Altematives to Reduce Pollution. Montana Department of Environmental Quality. 


\section{Project Title:}

\section{Bi-State Development Agency Alternative Fuel Bus Testing of 10 Buses}

Background: Congress enacted AMFA, which requires DOE to collect data on altemative fuel use by light-duty vehicles, heavy trucks, and heavy transit buses in the United States. DOE designated NREL in Golden, Colorado, as the program manager for the Vehicle Evaluation Program. NREL collects altemative fuel vehicle data in its AFDC and allows the public to access fleet operations and emissions data on various altemative fuels.

NREL, with funding from DOE, initiated this project to study the performance, reliability, costs, and emissions of altemative fuel transit buses versus conventional diesel buses (controls). The project involved collecting detailed operational and maintenance data from more than 100 buses at eight transit agencies across the country. Biodiesel blends were tested at the St. Louis, Missouri site.

\section{Objectives:}

- Gather detailed information on the reliability, operating costs, and emissions levels of biodiesel and other altemative fuels (natural gas, methanol, ethanol and propane) currently in use in the transit bus industry.

- Provide detailed data on transit bus operations to NREL for public access to the AFDC.

- Provide unbiased comparisons of heavy-duty alternative and diesel transit buses currently in use.

- Run five 40 -foot flexible fuel buses on $20 \%$ biodiesel and five control buses on conventional diesel (a program goal was to have 10 test buses of each alternative fuel type, with 10 controls, operating for 18 months).

Status: 1992-June 1996.

Accomplishments:

- For this test, 100,000 miles were driven on the biodiesel blend.

- A final project report was published in 1996.

Participants: Bi-State Development Agency, National Biodiesel Board, National Renewable Energy Laboratory, University of Missouri, Battelle, West Virginia University

Sponsoring Organization(s): U.S. Department of Energy Office of Fuels Development

Point of Contact: Paul Norton, National Renewable Energy Laboratory, 1617 Cole Blvd., Golden, CO 80401-3393, phone 303.275.4424, fax 303.275.4415, e-mail nortonp@nrel.gov. Ms. Bev Thessen, National Biodiesel Board, P.O. Box 104898, Jefferson City, MO, 651104898, phone 573.635.3893, fax 573.635.7913, e-mail biodiesel@ sockets.net.

\section{Papers:}

Motta, R. et al. (1996). "Altemative Fuel Transit Buses: Final Results from the National Renewable Energy Laboratory Vehicle Evaluation Program" Produced for the U.S. Department of Energy by the National Renewable Energy Laboratory. NRELTP-425-20513.

Chandler, K.L et al. (1996). "Altemative Fuel Transit Bus Evaluation Results.” Battelle, Columbus, Ohio. 
Chandler, K., et al. (1996). "Alternative Fuel Transit Bus Evaluation Program Results." SAE Technical Paper Series \#961082. Intemational Spring Fuels and Lubricant Proceedings.

Abstract.

Krahl, J., et al. (1996). "Survey About Biodiesel Exhaust Emissions and Their Environmental Effects." Proceedings of the Third Liquid Fuel Conference, September 15-17, Nashville, TN. pp. 136-148.

Krahl, J., et al. (1996). "Review: Utilization of Rapeseed Oil, Rapeseed Oil Methyl Ester or Diesel Fuel: Exhaust Gas Emissions and Estimation of Environmental Effects." Paper \#962096. Proceedings of the International Truck \& Bus Meeting and Exposition. Abstract.

Schumacher, L., et al. (1996). “100,000 Miles of Fueling 5.9 L Cummins Engines with 100 Percent Biodiesel." Paper \#962233. Proceedings of the Intemational Truck and Bus Meeting and Exposition. Abstract.

Schumacher, L. and J. Van Gerpen (1996). "Research Needs Resulting from Experiences of Fueling Engines with Biodiesel." Proceedings of the Third Liquid Fuel Conference, September 15-17, Nashville, TN. pp. 207-216.

Schumacher, L., S. Howell, and A. Weber (1996). "Biodiesel Research--1996 and Beyond." Proceedings of the Third Liquid Fuel Conference, September 15-17, Nashville, TN. pp. 217224.

Additional Information: CRIS Accession No.: 9165626. 


\section{Project Title:}

Boston, Massachusetts Bus Fleet Operating on Biodiesel

Background: This research seeks to determine whether a fleet of buses can perform successfully when operating on biodiesel. Additionally, it expands the awareness and use of biodiesel as a motor fuel.

Objectives: To successfully operate several city buses on biodiesel.

Status: September 1995-present

Accomplishments:

- Currently four MBTA buses are operating on biodiesel.

- TRT supplies 8,000 gallons of biodiesel per year for those vehicles.

Participants: City of Boston, State Agency Transit Authority, and Twin Rivers Technologies, Inc.

Sponsoring Organization(s): City of Boston, State Agency Transit Authority, Twin Rivers Technologies, Inc.

Point of Contact: Andrew Brennen, State Agency Transit Authority, phone 617.222.3126. Irving Sacks, Division of Energy Resources, 100 Cambridge Street, 15th Floor, Boston, MA 02202, phone 617.727.4732, ext. 131, fax 617.727.0030.

Paper: None available. 
Project Title:

Clean Air Partners--Biodiesel Water Shuttles at Logan Airport

Background: To demonstrate clean fuel technologies such as the Airport Water Shuttle using $\mathrm{B}-20$, to reduce harmful emissions from conventional diesel, and lessen exposure to air pollution in the airport vicinity. Three water shuttles using the biodiesel deliver passengers to Rowe's Wharf in Boston. This fuel is provided by TRT, Quincy, MA.

Objectives: Not available.

Status: FY 1996 (mid-June to October)

\section{Accomplishments:}

- Before running the boats on biodiesel, a survey was performed of boat operators to reveal biodiesel perceptions. The boats started running biodiesel in mid-June 1996 and continued through mid-October 1996.

- A series of tests was run on one boat to test for air emissions such as $\mathrm{CO}$ and $\mathrm{NO}_{\mathrm{x}}$, and opacity (soot) at various stages of the project.

- Later in the project, the timing was adjusted on the engine and a catalyst was added to the exhaust system to test its effect on emissions. Boston Harbor Commuter Service honored a coupon provided by New England Power to help pay for the additional cost of the biodiesel additive.

Participants: Beacon Management Company (water shuttle operators); Boston Harbor Commuter Service (owners of shuttle), Massachusetts Port Authority, New England Power, Twin Rivers Technologies, Inc., and U.S. Environmental Protection Agency

Sponsoring Organization(s): New England Power with some assistance from U.S. Environmental Protection Agency, New England Region, and cost-shared by Twin Rivers Technologies, Inc.

Point of Contact: Deborah Donovan, New England Power, 25 Research Drive, Westborough, MA 01582, phone 508.389.2590, fax 508.389.3385. Paul Angelico, Twin Rivers Technologies, Inc., 780 Washington Street, Quincy, MA 02169, phone 617.745.4204, fax 617.472.5460. Lucy Edmondson, EPA, New England Region, John F. Kennedy Federal Building, Mail Code RAA, Boston, MA 02203, phone 617.565.9095, fax 617.565.3415.

Papers: None available at this time 


\section{Project Title:}

Demonstrate 35 Percent Biodiesel Blends in Line Haul Tractors Using DDC Series 60 and Cummins 855 Engines

Background: Biodiesel has been demonstrated in a number of heavy-duty applications. However few of these demonstrations were in trucks. This project will evaluate the performance and reliablity of biodiesel in trucking applications.

Objectives: The objective of this project is to evaluate the viability of running line-haul trucks on a mixture of $35 \%$ soydiesel and $65 \%$ conventional diesel fuel.

Status: FY 1994-FY 1998

Accomplishments: Trucks have been in operation since January 1995. During the winter of 1995-1996, fuel filter plugging was encountered. Fuel tank heaters were used during the winter of 1996-1997 and no fuel filter plugging occurred.

Participants: Ag Processing Inc.; Trucking Research Institute, National Renewable Energy Laboratory

Sponsoring Organization(s): U.S. Department of Energy

Point of Contact: Paul Norton, National Renewable Energy Laboratory, 1617 Cole Blvd., Golden, CO 80401-3393, phone 303.275.4424, fax 303.275.4415, e-mail nortonp@nrel.gov.

Papers: Final report will be available in second quarter 1998. 


\section{Project Title:}

\section{Demonstrate and Promote Biodiesel as a Transportation Fuel}

Background: CAAA-90 mandates reductions in the emissions of $\mathrm{NO}_{x}, \mathrm{CO}$, particulates, and other air toxins from the combustion of motor fuels in automobiles and trucks. For buses, trucks, and waterbome vehicles, biodiesel can be an attractive altemative. It offers a positive impact on air emissions in the Northeast. However, biodiesel is not a well-known fuel and the impacts of its use are little understood. Consequently, promotion of the results is a primary component of this project.

Objectives:

- Promote the development of biodiesel through its use as a "fuel fix" to meet air emission requirements by interested northeastem states.

- Focus on conducting demonstrations for marine, urban bus, and trains using blends and neat biodiesel. NRBP will also monitor and report the results of the demonstrations relating particularly to the reduction of air emissions, the operational performance, and infrastructure issues encountered.

\section{Status: FY 1996}

Accomplishments: The project began in the summer of 1996.

Participants: Northeast Regional Biomass Program, U.S. Department of Energy Clean Cities Program

Sponsoring Organization(s): Northeast Regional Biomass Program

Point of Contact: Richard Handley, Northeast Regional Biomass Program, CONEG Policy Research Center, Inc., 400 N. Capitol St., Suite 382, Washington, DC 20001, phone 518.899.9572, fax 518.899.9574, e-mail mandley@ capital.net

Papers:

Evaluation and Cost of Compliance Analysis of Biodiesel Fuel for MBTA Buses, Submitted to MBTA by Rizzo Associates. 


\section{Project Title:}

Demonstrate Biodiesel in Commuter Trains and Buses

Background: The Northeast has the highest concentration rail mass transit in the nation. Millions of commuters in this region use the bus and train systems each day. Mass transit offers many energy benefits, but the benefit that remains untapped is its ability to create a market for biofuels. Mass transit offers the fastest, most cost-effective, near-term way to get people using biofuels. Biofuels in buses and commuter trains reduce air pollution, especially during peak commuter times. The focus of this project is on completing the testing of biodiesel in diesel locomotive engines.

Objective: To increase the near-term use of biofuels while displacing conventional fuel consumption and reducing air pollution in the Northeast and inform locomotive operating companies of the option to reduce $\mathrm{NO}_{x}$ and particulates through the use of biodiesel.

Status: Start date is spring 1997.

\section{Accomplishments:}

- NRBP will retain a consultant to identify the economic and operational concems of transit officials using biodiesel and identify transit systems willing to participate in a demonstration to validate or refute those concerns.

Participants: Original equipment manufacturers, as well as the federal agencies such as U.S. Department of Energy, U.S. Department of Transportation, and U.S. Environmental Protection Agency, would be likely participants in this project. Other possible participants include N.Y. Department of Transportation, the N.Y. Research and Development Agency, Allied Signal, and Amtrak.

Sponsoring Organization(s): Northeast Regional Biomass Program

Point of Contact: Richard Handley, Northeast Regional Biomass Program, CONEG Policy Research Center, Inc., 400 N. Capitol St., Suite 382, Washington, DC 20001, phone 518.899.9572, fax 518.899-9574, e-mail rhandley@ capital.net

Papers: None available at this time 


\section{Project Title:}

Demonstration of the On-the-Road Use of Biodiesel

Background: This project was intended as a demonstration effort that would add to the database of performance information on biodiesel.

\section{Objectives:}

- Demonstrate the operational feasibility of using biodiesel in blends of both NR oil and RME with diesel fuel in on-the-road vehicles.

- The project target was 100,000 miles of operation for both biodiesel-fueled pickup trucks by Fall of 1996 . When the Dodge reached 100,000 miles, its engine was disassembled to determine the effects of the $20 \%$ RME blend.

Status: August 1992 to October 1996

Accomplishments:

- As of July 3, 1996, 92,856 miles had been accumulated on the 1992 Dodge pickup and 1,884 engine hours. The average fuel blend was $27.9 \%$ RME to $72.1 \%$ petroleum diesel, 1,217 , and 3,133 gallons respectively. Average recorded mileage has been $21 \mathrm{mpg}$ of blended fuel.

Participants: University of Idaho, U.S. Department of Agriculture-Agricultural Research Service, Western States Caterpillar, Idaho Department of Water Resources, McGregor Company, and Pepsi Cola Bottling Company.

Sponsoring Organization(s): Pacific Northwest and Alaska Regional Biomass Energy Program

Point of Contact: Gerald Fleishman, Energy Engineer, phone 208.327.7659; Dr. Charles L. Peterson, Department of Agricultural Engineering, University of Idaho, Moscow, ID 83844, phone 208.885.7906, fax 208.885.8923.

Papers:

Peterson, C. (1997). Final Report: Demonstration of the On-the-Road Use of Biodiesel. 


\section{Project Title:}

Development of Rapeseed Biodiesel for Use in High-Speed Diesel Engines

Background: This five-phase project was intended to not only support demonstration and development of rapeseed through operational demonstration and emission testing, but also provide an economic assessment and commercial viability analysis. Additionally, this project was intended to increase public education and available information regarding rapeseed biodiesel.

\section{Objectives:}

- Design, develop, refine, and demonstrate a biodiesel process using rapeseed oil as a feedstock.

- Test and characterize the fuel.

- Test diesel engine performance.

- Analyze commercial viability and test environmental sensitivity.

- Perform on-the-road demonstrations using 100\% REE biodiesel.

Status: June 1993 to-June 1995

\section{Accomplishments:}

- Test information is available on horsepower to the wheels, torque, fuel consumption, fuel temperature, inlet air temperature, coolant temperature, exhaust temperature, engine blowby, engine rpm, and turbo boost pressure.

Participants: U.S. Department of Agriculture; McGregor Company of Colfax, Washington; the Pepsi Cola Bottling Company; Westem State Caterpillar; Ethanol Pacific, Inc.; and Pacific Northwest Rapeseed and Canola Growers Association.

Sponsoring Organization(s): Pacific Northwest and Alaska Regional Biomass Energy Program

Point of Contact: Dr. Charles L. Peterson, Department of Agricultural Engineering, University of Idaho, Moscow, ID 83844, phone 208.885.7906, fax 208.885.8923, e-mail peterson@novell.uidaho.edu.

\section{Papers:}

EMA 200 Hour Test, Rapeseed Methyl Ester and Ethyl Esters and Diesel Fuel, September 1995.

Nordham, M.(1994). Cost Benefit Analysis of Rapeseed Production.

Peterson, C.L.; Reece, D.L.; Thompson, J.L.; Zhang, X; Hammond, B.L.; Beck, S. (1996). Development of Rapeseed Biodiesel for Use in High-Speed Diesel Engines. Contract \# 93BIO9233. Moscow, ID: University of Idaho College of Agriculture. Available from Idaho Agricultural Experiment Station, University of Idaho, Moscow, ID 83844. 


\section{Project Title:}

Expanded Rapeseed Ethyl Ester (REE) Demonstration and Testing, and Cooperative Development of Hydrogenated Soy Ethyl Ester (HySEE) Biodiesel

Background: This project is an extension of other work that the program has been engaging in related to high-speed diesel engines.

Objectives:

- Expand current REE demonstration and testing.

- Support a cooperative development of hydrogenated soy ethyl ester biodiesel.

Status: October 1994-December 1995

\section{Accomplishments:}

- The 1994 Dodge pickup had 45,890 miles, 44,290 of which were on REE (as of September 1996). This vehicle has consumed $2,368.4$ gallons of REE for an average fuel consumption of $18.7 \mathrm{mpg}$.

- Engine oil analysis continues to show that no corrective actions are required.

- Conducted HySEE biodiesel testing and analysis.

Participants: University of Idaho; J.R. Simplot; American Society of Agricultural Engineers; Idaho Department of Water Resources.

Sponsoring Organization(s): Pacific Northwest and Alaska Regional Biomass Energy Program

Point of Contact: Dr. Charles L. Peterson, Department of Agricultural Engineering, University of Idaho, Moscow, ID 83844, 208.885.7906, fax 208.885.8923, e-mail

peterson@novell.uidaho.edu

Papers:

Peterson, et. al, (1996). "Development of Rapeseed Biodiesel for Use in High-Speed Diesel Engines." Conference Proceedings, Commercialization of Biodiesel: Establishment of Engine Warranties, November 9-10, 1995. 


\section{Project Title:}

Fueling Urban Buses with Soydiesel-Diesel Fuel Blending

Background: Biodiesel as a fuel for diesel powered transportation vehicles has been tested in several locations across the United States since July 1991. Little effort had been made to systematically, qualitatively, and quantitatively collect and record vehicle performance and operational characteristics. The collection of this information is essential to the market development of biodiesel in the United States.

Performance data have been collected from urban mass transit buses across the United States that have been fueled with blends of biodiesel and petroleum diesel. Approximately 30 demonstration projects were initiated through this effort. Data from one mass transit agency will become a part of the AFDC in Golden, Colorado. This project will provide real-world data that will be used for marketing and promotional purposes during the commercialization of biodiesel.

\section{Objectives:}

- Establish cooperative relationships and collect qualitative and quantitative vehicle performance and operational data from a mass transit district.

- Summarize retrieved information and format appropriately for NREL's AFDC.

- Transfer data electronically to NREL's AFDC database.

- Develop cooperative relationships with other agencies to collect vehicle performance and operational data and submit these data to NREL.

Status: 1995

\section{Accomplishments:}

- Researchers collected data from biodiesel demonstrations that were placed in the AFDC.

- Bi-State Development Agency of St. Louis was selected as the site for a highly controlled data collection activity.

- Vehicle operators were pleased with the performance of the fuel.

Participants: University of Missouri, National Biodiesel Board, National Renewable Energy Laboratory

Sponsoring Organization(s): National Biodiesel Board

Point of Contact: Ms. Bev Thessen, National Biodiesel Board, P.O. Box 104898, Jefferson City, MO, 65110-4898, phone 573.635.3893, fax 573.635.7913, e-mail biodiesel@ sockets.net. Leon Schumacher, University of Missouri, 235 Agricultural Engineering Building, University of Missouri, Columbia, MO 65211, phone 573.882.2126, fax 573.882.3958, e-mail leon schumacher@muccmail.missouri.edu.

\section{Paper(s):}

Schumacher, L.G.; Weber, J.A.; Russell, M.D. (1994). "Fueling Urban Buses with SoydieselDiesel Fuel Blending." Proceedings of the 6th National Bioenergy Conference, vol. I, Bioenergy '94, Reno-Sparks, NV. Westem Regional Biomass Energy Program, pp. 11-18. 
Schumacher, L.G. ; Weber, J.A. (1994) "Collection and Collation of Performance Data From Urban Mass Transit Biodiesel Demonstrations". Proceedings of an Altemative Energy

Conference, Kansas City, MO. American Society of Agricultural Engineers Summer Meeting 1994, pp. 39-46.

Schumacher, L.G.; Weber, J.A.; Russel, M.D.; Krahl, J.G. (1995). "An Alternative Fuel for Urban Buses - Biodiesel Blends" Proceedings of the Second Biomass Conference of the Americas, Portland OR, pp. 893-901. 


\section{Project Title:}

Hydrogenated Soy Ethyl Ester (HySEE) Production and Engine Durability Test Project

Background: Since biodiesel is a potential non-petroleum, domestically produced diesel engine fuel, HySEE development was viewed as a worthwhile activity for investment.

Objectives: This project was designed to produce 2,000 gallons of HySEE from waste french fry oil and ethanol. It will then be tested in three separate 1,000-hour engine durability tests.

Status: October 21, 1996-present

Accomplishments: As of October 1996, the project was in progress.

Participants: University of Idaho/Chemical Engineering and J.R. Simplot Company

Sponsoring Organization(s): Pacific Northwest and Alaska Regional Biomass Energy Program

Point of Contact: Dr. Charles L. Peterson, Department of Agricultural Engineering, University of Idaho, Moscow, ID 83844, phone 208.885.7906, fax 208.885.8923, e-mail peterson@novell.uidaho.edu.

Papers:

Peterson, C. (1997). Draft: 1000 Hour Engine Durability Testing with HySEE. 


\section{Project Title:}

lowa Heavy Vehicle Fleet Biodiesel Test at lowa Department of Transportation, Boone Maintenance Facility

Background: IDOT wanted to determine the feasibility of an entire fleet operating on $20 \%$ blends of biodiesel for 1 year. The state was considering biodiesel as a low-cost option to comply with EPAct.

\section{Objectives:}

- Nine snow removal trucks, four tractors, a motor grader and a wheel loader (the entire Boone maintenance fleet) was tested on $20 \%$ SME for 1 year.

- The Boone fleet IDOT maintenance facility used 15,650 gallons of biodiesel fuel for the test.

- 2,920 gallons of biodiesel were pumped out of the underground storage tank at Boone maintenance and mixed with diesel fuel.

Status: December 20, 1994-March 1996

Accomplishments: The fleet changed from No. 2 diesel to No. 1 diesel after operators reported a loss of power and fuel economy.

Participants: The Boone maintenance facility and fleet, lowa Department of Transportation, Fosseen Manufacturing and Development.

Sponsoring Organization(s): lowa Department of Transporation

Point of Contact: Kevon Jones, IDOT, 800 Lincoln Way Ames, IA 50010, phone 515.239.1670, fax 515.239.1658. Pat Paustian, Department of Agriculture's Office of Renewable Fuels, 502 E. 9th Street, Wallace Building, Des Moines, IA 50319, phone 515.281.6936.

\section{Paper:}

October 1996; Final Report issued by the Public Transit Systems and lowa Department of Transportation Heavy Duty Vehicle. 


\section{Project Title:}

Massachusetts Biodiesel Shuttle System

Background: A clean fuel is needed for a possible shuttle system in Boston. Boston, in conjunction with MBTA, plans to build a tunnel from the city to the waterfront. Boston has strict regulations against the use of compressed fuels being transported through tunnels, thus precluding altemative fuels such as CNG or propane from being considered. The city officials want to use heavy AFVs, so it must be determined which fuel options are available.

Objectives: To valuate biodiesel as a possible fuel of choice in the shuttle vehicles that would operate in the tunnels.

Status: Possible project for FY 1998

Accomplishments: Project in preliminary stages.

Participants: City of Boston, Massachusetts Bay Transit Authority

Sponsoring Organization(s): Massachusetts Bay Transit Authority

Point of Contact: Andrew Brennen, State Agency Transit Authority, phone 617.222.3126, Irving Sacks, Division of Energy Resources, 100 Cambridge Street, 15th Floor Boston, MA 02202, phone 617.727.4732 ext. 131, fax 617.727.0030.

Paper: None available at this time. 


\section{Project Title:}

Methyl Ester Demonstration in Diesel Engines

Background: The idea behind this project was to identify the best way to inform the agricultural community about biodiesel use in farm equipment. Demonstrations of community events were chosen as the medium.

Objectives: To publicize the advantages of biodiesel in the Missouri agricultural community. Two tractors fueled with biodiesel were exhibited at fairs, agricultural shows, and conventions across the state of Missouri. Media coverage and literature on biodiesel were also provided. The lack of operating difficulties and the lower emissions were also stressed at the demonstrations.

\section{Status: FY 1993-FY 1994}

Accomplishments: The displays increased the agricultural public awareness of biodiesel.

Participants: University of Missouri, State of Missouri, Southeast Regional Biomass Energy Program

\section{Sponsoring Organization(s): Southeast Regional Biomass Energy Program}

Point of Contact: Leon Schumacher, University of Missouri, 235 Agricultural Engineering Building, University of Missouri, Columbia, MO 65211, phone 573.882.2126, fax 573.882.3958, e-mail leon schumacher@muccmail.missouri.edu.

\section{Papers:}

Schumacher, L.G., S.C. Borgelt; W.G. Hines (1995). Fueling Engines with Soy Diesel/Diesel Fuel Blends. Missouri Department of Natural Resources, Columbia, MO. Available from Southeast Regional Biomass Energy Program. 


\section{Project Title:}

Nebraska Biodiesel Pilot Project

Background: This ongoing project was begun as an attempt to further illustrate how biodiesel can be used in on-road equipment.

Objective: To test $10 \%$ biodiesel blended fuel in heavy-duty diesel truck engines. The Nebraska Department of Roads, in cooperation with the Nebraska Energy Office and the Nebraska Soybean Board, will use the fuel in approximately $20 \%$ of the state's heavy-duty vehicle fleet in 1997.

Status: September 1996-December 1997

Accomplishments: The project was initiated in September 1996.

Participants: Nebraska Department of Roads, the Nebraska Energy Office, and the Nebraska Soybean Board.

Sponsoring Organization(s): Westem Regional Biomass Energy Program

Point of Contact: Mary Jo Hall, Nebraska Department of Roads, 1500 Highway 2, P.O. Box 94759, Lincoln, NE 68509-4759, phone 402.479.4301, fax 402.479.4325, e-mail dor28994@ vmhost.cdp.state.ne.us.

Papers: None available at this time. 


\section{Project Title:}

New Jersey Transit Demonstration

Background: New Jersey Transit has expressed interest in demonstrating the use of biodiesel in its transit system as a cost-effective means of achieving clean air and energy policy goals. This project is designed to demonstrate biodiesel's feasibility and performance.

\section{Objectives:}

- Demonstrate biodiesel benefits in transit applications.

- Increase industry awareness of biodiesel as a fuel option for transit fleets.

- Develop a long-term fuel distribution contract with transit organization.

Status: In process.

Accomplishments: Details regarding the fueling and logistics are being planned.

Participants: New Jersey Transit

Sponsoring Organization(s): National Biodiesel Board and the United Soybean Board.

Point of Contact: Ms. Bev Thessen, National Biodiesel Board, P.O. Box 104898, Jefferson City, MO, 65110-4898, phone 573.635.3893, fax 573.635.7913, e-mail biodiesel@ sockets.net

Paper: None 
Project Title:

Omaha Nebraska Metro Transit Biodiesel Buses

Background: The State of Nebraska was interested in creating interest in biodiesel. The energy office initiated this demonstration project to help generate interest.

Objectives: To test 130 Nebraska Metro Transit buses operating on a $20 \%$ biodiesel blend.

Status: May 6, 1996-May 6, 1997

Accomplishments: Project in initial stages

Participants: Star Trans, Metro Transit of Nebraska, Nebraska Energy Office, Nebraska Soybean Association, City of Lincoln, Nebraska

Sponsoring Organization(s): Metro Transit of Nebraska, Nebraska Soybean Association, City of Lincoln, Nebraska

Point of Contact: Jerry Loos, Nebraska Energy Office, P.O. Box 95085, Lincoln, NE 68509, phone 402.471.2867, fax 402.471.3064; Larry Worth, Star Trans, $710 \mathrm{~J}$ Street, Lincoln, NE 68508, phone 402.441.8600, fax 402.471.7055.

Paper: None available at this time 


\section{Project Title:}

Over-the-Road Heavy-Duty Diesel Engine Operational Demonstration

Background: The idea behind this project was to provide intensive performance information regarding the use of biodiesel in a heavy-duty vehicle.

\section{Objectives:}

- Complete a long-haul (200,000-mile) operational demonstration using a Caterpillar 3406E engine fueled with a 50/50 blend of biodiesel and petroleum diesel. The demonstration vehicle will be used in actual commercial operation.

- This three-phase project will consist of engine testing; an operational over-the-road demonstration; and thorough engine performance and emissions testing and engine inspection.

Status: May 12, 1997-October 31, 1999.

Accomplishments:

- The truck will operate more than 200,000 miles.

Participants: Caterpillar, Inc.; University of Idaho's Department of Biological and Agricultural Engineering; J.R. Simplot Company; Kenworth Truck Company; and the University of Califomia Davis' Department of Environmental Toxicology; Trebar Inc.; Westem States Cat, Idaho Department of Water Resources Energy Division; Pacific Northwest and Alaska Regional Biomass Energy Program

Sponsoring Organization(s): Pacific Northwest and Alaska Regional Biomass Energy Program

Point of Contact: Dr. Charles L. Peterson, Department of Agricultural Engineering, University of Idaho, Moscow, ID 83844, 208.885.7906, fax 208.885.8923, e-mail peterson @ novell.uidaho.edu.

Papers:

Peterson, C. (1997). Fuel Production Quality Assurance Plan. 


\section{Project Title:}

Pilot Demonstration of Biodiesel in Tourism-Related Transportation: A Truck in the Park

Background: This project investigates the market acceptance of REE fuel for diesel engines to reduce pollution, odors, and visible particulates caused by tourism transportation.

\section{Objectives:}

- Further the commercialization of biodiesel blend fuels.

- Operate a diesel truck in Yellowstone National Park for 2 years fueled with $100 \%$ REE. After the 2 years, the truck will have traveled approximately 100,000 miles.

- The demonstration includes diesel engine performance testing, normal service and maintenance, and periodic emissions testing at qualified facilities.

Status: October 15, 1994-December 30, 1996

\section{Accomplishments:}

- As of August 26, 1996, the National Park Service Biodiesel Demonstration Vehicle has traveled more than 39,251 miles, 36,068 of which was on $100 \%$ biodiesel.

- The truck had consumed 2,212.8 gallons of biodiesel for an average mileage of $16.3 \mathrm{mpg}$. The detailed engine emissions tests in Los Angeles will occur in mid-1997. After the project is completed, the engine will be taken apart and examined for wear.

Participants: Montana Department of Environmental Quality

Sponsoring Organization(s): Pacific Northwest and Alaska Regional Biomass Energy Program

Point of Contact: Howard Haines, Department of Environmental Quality, P.O. Box 200901, Helena, MT 59620-0901, phone 406.444.6773, fax 406.444.1804, e-mail hhaines@mt.gov.

\section{Papers:}

Peterson, et. al., (1995). "Producing Biodiesel for the 'Truck in the Park' Project." Biomass Conference of the Americas, Portland, Oregon, August 22.

Haines, H. (1995). "Status Report on the Truck in the Park Demonstration Project." Montana DEQ, Helena, MT. 


\section{Project Title:}

\section{Promotion of Agricultural Soydiesel Use in South Carolina}

Background: This project was driven by the intention to promote additional uses of regionally grown soybeans to improve the South Carolina economy and further the move toward alternative renewable transportation fuels.

\section{Objectives:}

- Improve production of biodiesel and promote the use of soybean products.

- The Soybean Board of South Carolina and Clemson University collaborated to promote the use of soydiesel in the agricultural community by operating a soydiesel truck to carry out soybean research, conducting demonstrations, and producing promotional literature.

\section{Status: FY 1994-FY 1995}

Accomplishments:

- A pamphlet was produced and published for distribution between January and April 1995. The final report has been drafted and reviewed, but has not been approved for publication yet.

Participants: State of South Carolina, Clemson University, and the South Carolina Soybean Board.

Sponsoring Organization(s): Southeast Regional Biomass Energy Program

Point of Contact: Emerson Shipe, Clemson University, Department of Crop and Soil Environmental Science, 277 P\&A Building, Clemson SC 27634-0359, phone 864.656.3524, fax 864.656.3443, e-mail eshipe@ clemson.edu.

Papers:

Shipe, E.R. (1995). Final Contract Report: Soydiesel-Fueled Truck Demonstration. Clemson University, Clemson, SC. Available from Southeast Regional Biomass Energy Program. 


\section{Project Title:}

Rhode Island Energy Office and Department of Transportation Ferry Boat Program

Background: The Rhode Island Energy Office will work with the state DOT to have biodiesel used as one of the fuels in the Ferry Boat Program.

Objective: To demonstrate biodiesel in marine watercraft to highlight its compatibility in diesel engines, particularly hi-speed marine vehicles.

\section{Status: FY 1997}

Accomplishments: As of April 1997, the bidding contract was out for planning, design, construction, and implementation.

Participants: Rhode Island State Energy Office; Rhode Island DOT

Sponsoring Organization(s): Northeast Regional Biomass Program

Point of Contact: Julie Capobianco, Department of Administration, Division of Central Services, Rhode Island State Energy Office, 1 Capitol Hill, Providence, RI 02908, phone 401.222.3370, fax 401.222.1260.

Papers: None available at this time. 


\section{Project Title:}

Soy-Diesel Blends' Use in Aviation Turbine Engines

Background: Global energy and environmental concems have brought about an urgent search for altemative fuel sources in aviation.

Objectives: To determine whether the essential qualities required of an aviation-grade fuel were present in a soy-diesel blend.

Status: 1995

Accomplishments:

- Biodiesel blended fuel showed markedly superior lubricity values compared to straight.

- Fuel consumption figures indicate that soy-diesel blends are compatible enough to allow further testing.

- Future testing on blends of $10 \%$ or $20 \%$ soy-diesel should be performed.

Participants: Purdue University Aviation Technology Department

Sponsoring Organization(s): Indiana Soybean Growers Association

Point of Contact: Denver Lopp, Aviation Technology Building, 1 Purdue Airport, West Lafayette, IN 47906; phone 317.494.6387.

Paper(s):

Lopp, D.; Stanley, D.; Ropp, T.; Cholis, J. (1995). Soy-Diesel Blends Use in Aviation Turbine Engines. West LaFayatte, IN: Department of Aviation Technology, Purdue University. Available from the Indiana Soybean Growers Association, Lebanon, IN 46052. 


\section{Project Title:}

Tallow-Based Biodiesel Test at the Kansas City Area Transit Authority

Background: Because tallow is an abundant resource in the Kansas City area, it was deemed as a viable demonstration effort to use regional resources.

\section{Objectives:}

- Compare the effect of tallow use on engine wear metals.

- Power four metro buses on $20 \% / 80 \%$ tallow/diesel blended fuel. Four control buses will be examined over the same time frame running on straight petroleum-based diesel fuel.

Status: May 15, 1997-December 31, 1997

Accomplishments: Scheduled to begin testing in May 1997.

Participants: MARC-IV Consulting, Inc., University of Nebraska

Sponsoring Organization(s): Westem Regional Biomass Energy Program

Point of Contact: Richard Nelson, University of Nebraska, Lincoln, NE 68588-0126, phone 913-532-4999.

Papers: None available at this time. 


\section{Project Title:}

The lowa Ames Transit Agency Biodiesel Bus Demonstration

Background: The Ames Transit Agency wanted to demonstrate the effectiveness of biodiesel as pollution mitigation strategy in transit applications.

\section{Objectives:}

- Obtain cleaner exhaust emissions.

- Maintain or increase fuel economy.

- Maintain horsepower.

- Log fleet maintenance records for demonstration and control buses.

- Assess ways and means of making biodiesel a viable additive/fuel supplement and a significant means of pollution mitigation among public transit systems and other commercial uses.

Status: January 1995-June 1995

Accomplishments:

- Twenty-five of a 42 bus fleet were included in the demonstration.

- Buses ranged in age from 2 to 15 years.

Participants: Ames Transit Agency, lowa Department of Transportation, Fosseen Manufacturing and Development

Sponsoring Organization(s): lowa Department of Transportation

Point of Contact: Pat Paustian, Department of Agriculture's Office of Renewable Fuels, 502 E. 9th Street, Wallace Building, Des Moines, IA 50319, phone 515.281.6936.

Paper: Final Report October 31, 1995 


\section{Project Title:}

Trash Truck and Bus B-20 Demonstration

Background: This project was driven by community interest in demonstrating the use of a regional crop product in a transportation application.

Objectives: To demonstrate the performance of biodiesel in normal city use over a long period. Two City of Columbia, Missouri vehicles, a bus and a refuse truck, were operated on a blend of $20 \%$ biodiesel and $80 \%$ petroleum diesel for about 1 year.

Status: November 1, 1993-October 15, 1994

Accomplishments: Demonstrated that biodiesel blends performed as well as diesel fuel, did not increase engine wear, and produced lower emissions.

Participants: University of Missouri, Missouri Division of Energy, City of Columbia, Southeast Regional Biomass Energy Program

Sponsoring Organization(s): Southeast Regional Biomass Energy Program

Point of Contact: Leon Schumacher, University of Missouri, 235 Agricultural Engineering Building, University of Missouri, Colombia, MO 65211, phone 573.882.2126, fax 573.882.3958, e-mail leon schumacher@muccmail.missouri.edu.

Papers:

Fueling Bus and Truck Engines with Soy Diesel, May 1995.

Schumacher, L.G., S.C. Borgelt and W.G. Hines (1995). Final Contract Report: Fueling City of Columbia Diesel Engines with a 20/80 Soydiesel Blend. University of Missouri, Columbia, MO. Available from Southeast Regional Biomass Energy Program. 


\section{Project Title:}

Twin Cities, Minnesota Biodiesel Pickup Truck Demonstration

Background: The U.S Bureau of Mines conducted research on biodiesel fuel made from esterified soybean oil for use in the underground mining industry. In this study, biodiesel fuel was found to reduce particulate emissions more than $70 \%$ both in the laboratory and in underground mines (see SAE Paper 950400, "Emission Characteristics of Soy Methyl Ester Fuels in an ID Compression Ignition Engine," J.F. McDonald, D.L. Purcell, B.T. McClure, and D.B. Kittelson, 1995). Based on the outcome of their research and knowing the requirements of EPAct, which requires federal agencies to purchase specific quantities of AFVs, Bureau personnel suggested to the Department of Interior Altemative Fuels Coordinator that a biodiesel demonstration be conducted in Twin Cities, Minnesota.

A joint effort was undertaken among the Department of the Interior, DOE, GSA, and the Minnesota Soybean Growers.

\section{Objectives:}

- Study the feasibility of using a biodiesel blend (50\%/50\% blend) in unmodified, light-duty diesel engine pickup trucks. The dates of the study were chosen to cover two summer driving seasons and one winter season.

- The project used nine 1995 Ford F250 two-wheel-drive pickup trucks. Six were powered with 7.3-L direct-injection turbodiesel V-8 engines, and three were powered by $5-L$ gasoline $\mathrm{V}-8$ engines. Three of the six diesel pickup trucks ran on a biodiesel blend. For comparison purposes, the other three diesels ran on conventional petroleum fuel.

Status: June 1995-December 1996.

Accomplishments:

- NREL funded emissions testing on one of the biodiesel trucks in May 1996. Five fuel/blends were tested: $100 \%$ petroleum and $25 \%, 50 \%, 75 \%$, and $100 \%$ SME. The emissions testing contract was to Automotive Testing Laboratoriesin East Liberty, Ohio, who subcontracted the testing to ORTECH in Canada.

- Results of this testing showed no major differences in any of the fuel blend ratios. However, this does not agree with other research conducted on heavy-duty engines, which has clearly shown a difference in emissions with different blend ratios.

- The report concludes that biodiesel appears to be a very viable alternative fuel. The biodiesel industry should work with DOE to arrive at a reasonable blend ratio--acceptable to DOE yet economical for the consumers.

- The biodiesel industry feels that considering the total energy offset in the production and consumption of biodiesel, a blend as low as $20 \%$ is correct.

Participants: U.S. Department of the Interior, National Renewable Energy Laboratory, General Services Administration, and the Minnesota Soybean Growers Association.

Sponsoring Organization(s): U.S. Department of Energy Office of Heavy Vehicle Technologies

Point of Contact: Peg Whalen, National Renewable Energy Laboratory, 1617 Cole Blvd., Golden, CO 80401-3393, phone 303.275.4479, fax 303.275.4415. 
Papers:

Kelly C. Strebig (1997). Final Report on the Twin Cities, Minnesota Biodiesel Pickup Truck

Demonstration. Prepared for the National Renewable Energy Laboratory. 


\section{Project Title:}

University of Minnesota Neat Biodiesel Pickup Demonstration and Outreach Project

Background: The State of Minnesota found that it required a high percentage of light pickup trucks to meet its EPAct requirements. However, the state found very few alternative fuel choices in pickup truck applications. Also, the Center for Diesel Research at the University of Minnesota approached the state to demonstrate neat biodiesel, an EPAct-approved fuel, in a northern climate. For these reasons, this project was designed to demonstrate consumer and driver acceptance of neat biodiesel in a light-duty pickup truck in a cold climate.

\section{Objectives:}

- Operate a pickup truck on $100 \%$ biodiesel while simultaneously doing biodiesel outreach.

- The pickup truck will be used for university fleet duties, such as running errands, transporting people to field mining sites, or hauling supplies.

- The project manager will evaluate the performance (including cold-start) and driver acceptance of this vehicle throughout the duration of the project.

- The project manager will involve the pickup truck in events or activities to provide the greatest exposure to public awareness.

- Presently, this project is not a field research demonstration project. It is strictly a public outreach demonstration.

Status: September 1, 1997-September 30, 1999.

Accomplishments:

- The Center for Diesel Research formed an advisory group to determining how to develop this project.

- Research has not yet begun because the University is waiting for the delivery of the General Motors pickup truck.

Participants: General Motors Company, Minnesota Soybean Association, State of Minnesota Department of Public Service, University of Minnesota, Center for Diesel Research

Sponsoring Organization(s): State of Minnesota Department of Public Service, Minnesota Soybean Association, General Motors Company

Point of Contact: Kelly Streibig, University of Minnesota, Center for Diesel Research, phone 612.457.1404, fax 612.725.0800, e-mail streb002@tc.umn.edu.

\section{Paper:}

None available at this time. 
Project Title:

Virginia Biodiesel Bus Demonstration and Test Operation

Background: The State of Virginia wanted to operate and test a biodiesel vehicle.

Objectives: To operate a biodiesel bus with assistance from the Greater Richmond Transit Commission.

Status: Unknown

Accomplishments:

- Nothing published at this point

Participants: Greater Richmond Transit Commission

Sponsoring Organization(s):

Point of Contact: Susan Thomas, State Energy Office, phone 804.692.3226. Phil Hickman, Director, Virginia Soybean Board, 1100 Bank Street, Suite 1005 Richmond, VA 23219, phone 804.371.6157. Marlo Allen, Virginia Soybean Association, phone 757.564.0153; Ralo Axton, GRTC, 101 S. Davis Street, Richmond, VA 23220, phone 804.358.3871/4782.

Paper: None available at this time. 


\section{Project Title:}

Virginia Boat Operating on Biodiesel

Background: To determine if biodiesel boats are practical in Virginia and elsewhere.

Objectives: To operate a boat on biodiesel, track the progress and record data.

Status: July 1, 1994-June 30, 1996

Accomplishments:

- Marine Resources Board sponsored a 43-foot work boat with a 300-horsepower John Deere Engine.

- The boat project has logged 1,000 operational hours on a $20 \%$ biodiesel blend.

- The boat was for an oyster rehabilitation project

Participants: Virginia Marine Resources Board

Sponsoring Organization(s): Virginia Marine Resources Board

Point of Contact: Susan Thomas, Virginia Soybean Board, 1100 Bank Street, Suite 1005 Richmond, VA 23219, phone 804.692.3226. Jim Wesson, Virginia Marine Resources Board, P.O. Box 756, Newport News, VA 23607-0756, phone 757.247.2121.

Paper: December 6, 1996 Final Report Issued 


\section{Project Title:}

Waco and Washington, lowa Community School District School Bus Demonstrations Using Biodiesel

Background: Four new school buses in WACO Community School District were upgraded to have the ability to use $30 \%-70 \%$ biodiesel depending on seasonal conditions. Washington Community School District buses were used as control vehicles.

Objectives: To collect information on the use of high blends of biodiesel while educating industry personnel on the safe and proper use of biodiesel fuel.

Status: The four test buses operated at $20 \%$ biodiesel and used $50 \%$ during summer months.

Accomplishments: During the winter months, fuel filter plugging was encountered prompting the installation of storage tank heaters and fuel system heaters for the buses. Testing of fuel by the University of lowa Hygienic Laboratory determined that the fuel has a tendency to stratify even before the cloud point causing the heavier biodiesel portion to sink to the bottom of the tank. Activities revolved around efforts to keep the fuel above $40^{\circ} \mathrm{F}$ at all times.

Participants: lowa Department of Natural Resources, Waco and Washington Community School Districts, National Renewable Energy Laboratory, lowa Soybean Association, Messer Oil Company, and Cummins Corporation.

Sponsoring Organization(s): U.S. Department of Energy Office of Heavy Vehicle Technologies

Point of Contact: Doug Schermer, Superintendent, Waco Community Schools, 611 N. Pear, Wayland, lowa, 52654, phone 319.256.6200, fax 319.256.6213. Ward Lenz, Program Planner, lowa Department of Natural Resources, Wallace State Office Building, Des Moines, IA 50319, phone 515.281.7018, fax 515.281.6794.

Papers: None available at this time. 


\section{Project Title:}

Wisconsin Biodiesel Bus Test

Background: To test a $20 \%$ biodiesel blend on an operational bus for 50,000 miles.

Objectives:

- Improve on the knowledge of biodiesel in mass transit applications.

- Promote biodiesel through long-term use.

Status: TBD

Accomplishments:

- The Madison Metro Transit System, University of Wisconsin (Center for Altemative Fuels), and Wisconsin Altemative Fuels Task Force all worked with Wisconsin Soybean on a $20 \%$ blend test over 50,000 miles.

Participants: The Madison Metro Transit System, University of Wisconsin (Center for Altemative Fuels), Wisconsin Altemative Fuels Task Force, Wisconsin Soybean Association

Sponsoring Organization(s): Wisconsin Soybean Association

Point of Contact: Nicole Anderson, Wisconsin Transportation Bureau, Div. of State Agency Services, P.O. Box 7867, Madison, WI 53707, phone 608.267.2715.

Paper: None available at this time 


\section{B. Market Analysis}

Also see the following projects:

A Proposed Biodiesel Development Plan

Biofuel Coproduct Development

Comprehensive Emissions and Chemical Characterization of Rapeseed Oil-Derived Biodiesel

Expanded Rapeseed Ethyl Ester (REE) Demonstration and Testing, and Cooperative Development of Hydrogenated Soy Ethyl Ester (HySEE) Biodiesel 


\section{Project Title:}

Biodiesel Market Opportunities and Potential Barriers

Background: During the past 3 years, NBB has investigated several markets that would use the characteristics and benefits of biodiesel/diesel blends. Industry task force groups have helped identify potential barriers to market penetration as well as highlight specific marketassessment studies, OEMs, EMA, industry, and others indicate that significant market penetration is possible in several market niches.

\section{Objectives:}

- Catalog the current biodiesel market.

- Discuss current barriers to the growth of the biodiesel industry.

- Identify possible new markets for biodiesel.

Status: Completed

Accomplishments: NBB consultants working on this project completed the following:

- Described a marketing approach for the biodiesel industry.

- Discussed the benefits and detriments of biodiesel compared to petrodiesel.

- Identified future market opportunities.

Participants: MARC-IV Consulting Inc.

Sponsoring Organization(s): National Biodiesel Board

Point of Contact: Ms. Bev Thessen, National Biodiesel Board, P.O. Box 104898, Jefferson City, MO, 65110-4898, phone 573.635.3893, fax 573.635.7913, e-mail biodiesel@ sockets.net. Alan Weber, MARC-IV Consulting Inc., 402 Oak Street, Ashland, MO 65010, phone 573.657.5537, fax 573.657.1058, e-mail aweber@marciv.com.

Paper Title:

Weber, J.A.; Johannes, K. (1996). "Biodiesel Market Opportunities and Potential Barriers" Proceedings of the Third Liquid Fuels Conference, September 15-17, Nashville, TN. Liquid Fuels and Industrial Products from Renewable Resources, pp. 350-357. 


\section{Project Title:}

Biodiesel Regulatory Fleet Program

Background: EPAct requires that federal, state and fuel provider fleets purchase AFVs. These fleets are a potential market for biodiesel, which is classified as an altemative fuel under EPAct. This marketing project was designed to position biodiesel as the least-cost compliance strategy for EPAct-regulated fleets.

\section{Objectives:}

- Regulated fleets could include federal, state and altemative fuel provider fleets. This project emphasized state fleets. As detailed in NBB's marketing plan, numerous states have formed altemative or renewable fuel task force programs. Because states are more nimble at introducing programs and may want to demonstrate leadership by working with tomorrow's technologies, biodiesel could find market access through state govemment initiatives.

- Using both performance and economic arguments and capitalizing on the success of previous demonstrations, this project includes an educational component for state agencies. It shall provide them with the rationale to consider implementing altemative fuel strategies employing biodiesel.

Status: August 1, 1995-September 30, 1996

\section{Accomplishments:}

- Project participants identified key decisions makers in states where activities are to be initiated, including Qualified State Soybean Boards, DOT administrators and maintenance supervisors, air quality officials, civic leaders, and federal fleet operators.

- With individual "covered fleets," B20 may be the compliance strategy with the least cost per mile of all the available alternatives.

- A conference, Regulated Fleets Biodiesel Option, was held in 1996.

Participants: Fleishman-Hillard and National Biodiesel Board

Sponsoring Organization(s): National Biodiesel Board

Point of Contact: Ms. Bev Thessen, National Biodiesel Board, P.O. Box 104898, Jefferson City, MO, 65110-4898, phone 573.635.3893, fax 573.635.7913, e-mail biodiesel @ sockets.net.

Paper:

Biodiesel Options EPAct Proceeding, available from the National Biodiesel Board, Jefferson City, MO. 


\section{Project Title:}

Combustion Analysis of Esters of Soybean Oil in a Diesel Engine

Background: Due to concem about the decrease of petroleum reserves and more stringent emissions standards for petroleum-fueled diesel engines, the development of altemative energy sources has become increasingly important. Many studies have shown that alkyl esters of soybean oil have similar fuel properties and engine performance compared with diesel fuel, but are nontoxic and biodegradable.

Objectives: The objective was to compare the emissions and combustion characteristics of blends of $20 \%, 50 \%$, and $70 \%$ (by mass) methyl; isopropyl, and winterized SME and winterized SME with commercial No. 2 diesel fuel.

Status: February 1996

Accomplishments:

- The engine experienced a decrease in engine delay when fueled with these blends.

- The esters are effective in reducing the total PM, solid carbon, $\mathrm{CO}$, and $\mathrm{HC}$ emissions.

- All ester/diesel fuel blends experienced the same combustion stages as diesel.

- The blends showed a similar diffusion burning rate to diesel.

Participants: lowa State University

Sponsoring Organization(s): lowa Soybean Promotion Board, lowa State University

Point of Contact: Jon Van Gerpen, Mechanical Engineering Department, lowa State University, 2025 Black Engineering Bldg., Ames, IA 50011-2161, 515.294.5563, fax 515.294.3261, e-mail jvg@iastate.edu.

Paper(s):

Zhang, Y.; Van Gerpen, J.. (1996). "Combustion Analysis of Esters of Soybean Oil in a Diesel Engine." Performance of Altemative Fuels for SI and CI Engines, February 26-29, Detroit, MI. SAE 960765. Warrendale, PA: Society of Automotive Engineers, Inc., pp. 1-15. 


\section{Project Title:}

\section{Low Blend Level Test Market (Premium Diesel Market)}

Background: The biodiesel market committee identified low-level blends or premium diesel markets to be a high priority for potential biodiesel sales. This project was funded to initiate sales in this market.

\section{Objectives:}

- Determine the potential market demand that could be generated for a premium biodiesel fuel containing low (less than $5 \%$ ) in petroleum diesel fuel.

- Use high profile retailers in targeted geographic areas, test the market by providing the premium fuel at pump outlets, and yield real numbers for use in forecasting broad market potential.

- Potentially develop an ongoing market for premium biodiesel at locations tested.

Status: January 1, 1997-present

\section{Accomplishments:}

- Arrangements with Ag Environmental Products and Farmland have been made to test market low blends of biodiesel in several Midwestem states.

- The test will continue through the summer of 1998.

Participants: Ag Environmental Products, Farmland Coop, Indiana Soybean Board, and National Biodiesel Board

Sponsoring Organization(s): Farmland Coop, Indiana Soybean Board, and National Biodiesel Board

Point of Contact: Ms. Bev Thessen, National Biodiesel Board, P.O. Box 104898, Jefferson City, MO, 65110-4898, phone 573.635.3893, fax 573.635.7913, e-mail biodiesel@ sockets.net. Mr. Doug Pickering, AEP, 9804 Pfumm, Lenexa, KS 66215, phone 913.599.6911, fax 913.599.2121.

Paper: None available. 


\section{Project Title:}

Market Opportunities for Diesel Technology

Background: At the start of the next millennium, evaporation of fuel will be the dominant source of VOC emissions from gasoline fueled automobiles, not the tailpipe. Great reductions in ground-level ozone could be realized by reducing the evaporation and atmospheric release of fuel from the automobile's fuel tank, from the vehicle refueling process, from the transport of fuel, and from the filling station's fuel holding tanks by reducing the volatility of gasoline.

\section{Objectives:}

- Provide diesel manufacturers with evidence of the magnitude of the near term diesel market to EPAct regulations.

- Estimate the potential for increased diesel engine (biodiesel FFV) sales due to EPAct regulations.

- Detail fleet inventories and EPACT State AFV Purchase Requirements of selected state government fleets.

- Survey the intent of fleets to consider biodiesel as compliance tool to meet regulatory requirements.

Status: June 1996

\section{Accomplishments:}

- Researchers leamed that fleet administrators are not enthusiastic about many pilot AFV programs.

- Fleet managers are aware of biodiesel, but seemed unaware of their ability to meet mandates by purchasing biodiesel FFVs and operating the vehicles on conventional petroleum diesel.

- Biodiesel FFVs can be presented to state fleet managers as a way to meet mandates and avoid the purchase of AFVs with price premiums.

Participants: University of Illinois

Sponsoring Organization(s): National Biodiesel Board

Point of Contact: Ms. Bev Thessen, National Biodiesel Board, P.O. Box, 104898, Jefferson City, MO, 65110-4898, phone 573.635.3893, fax 573.635.7913, e-mail biodiesel@ sockets.net.

Paper(s):

Smith, R.; Freestone, M. (June 1996). Market Opportunities for Diesel Technology: State Govemment Fleets and Energy Policy Act Mandates. NBB \# 54113-6. Jefferson City, MO: National Biodiesel Board. Work performed by Energy Resources Center, University of Illinois at Chicago. 


\section{Project Title:}

\section{Market Planning \& Task Force}

Background: The NBB determined that the establishment of a marketing plan and industry task force groups would accelerate the commercialization of biodiesel.

Objective: To accurately assess the potential for biodiesel in the U.S. markets, define the effort needed to achieve commercialization, and continuously refine its marketing strategy based on reliable information supported by the industry task forces. Specifically, the following objectives should be met:

- To use a collaborative decision making process for preparing and implementing research and market development activities.

- To create and maintain industry task forces pertaining to market research and development.

- Prepare outlook reports for each market: Regulated Fleets, Recreational Marine and Underground Mining.

- Facilitate task force meetings.

- Integrate industry task force committee feedback into final reports or activities.

Status: October 1995-September 1997

Accomplishments:

- The point of contact regularly distributes market reports to each market task force committee, thus allowing a formal process to review and approve each market planning strategy

- The point of contact also collects suggestions and/or recommendations and seeks further approval of marketing plan(s).

Participants: MARC-IV Consulting, Inc., National Biodiesel Board, Ohio Soybean Council, and United Soybean Board

Sponsoring Organization(s): National Biodiesel Board, Ohio Soybean Council, and United Soybean Board

Point of Contact: Ms. Bev Thessen, National Biodiesel Board, P.O. Box 104898, Jefferson City, MO 65110-4898, 573.635.3893, fax 573.635.7913, e-mail biodiesel@sockets.net:. Alan Weber, MARC-IV Consulting Inc., 402 Oak Street, Ashland, MO 65010, phone 573.657.5537, fax 573.657.1058, e-mail aweber@marciv.com.

\section{Paper:}

Weber, J.A.; Howell, S; Johannes, K. (1996). 1996-1998 Biodiesel Marketing Plan. Jefferson City, MO: National Biodiesel Board. 
Project Title:

Non-Fuel Industrial Uses of Soybean Oil-based Esters

Background: The high cost of producing biodiesel fuel must be compensated through increased biodiesel sales prices or the sale of co-products. Finding and documenting non-fuel markets for SMEs is to increase sales and drive up prices.

\section{Objectives:}

- Identify and evaluate industrial products that can be made from SMEs in addition to biodiesel fuels, and determine and rank uses that have the best opportunity for commercialization.

- Thoroughly examine products and product uses for SMEs beyond being used for fuel and physically test SMEs in the most promising selected uses.

Status: Completed January 31, 1997

\section{Accomplishments:}

- Researchers concluded that the biodiesel industry should not pursue new product applications in plasticizer, plastics, and lubricants.

- The industry could serve as a broker/promoter for biodiesel use in drilling muds, mineral floatation surfactant, and a pesticide adjutant.

- High-use biodiesel niches include advanced oil recovery and pipeline drag reducer applications that would require collaborations for the development of technology.

- There are two potentially significant applications for which the industry should consider sponsoring additional development for fatty acid use in paint removers and metals cleaning.

Participants: Development Systems/Applications Intemational, National Biodiesel Board, and University of Missouri-Columbia

Sponsoring Organization(s): National Biodiesel Board

Point of Contact: Ms. Bev Thessen, National Biodiesel Board, P.O. Box 104898, Jefferson City, MO, 65110-4898, phone 573.635.3893, fax 573.635.7913, e-mail biodiesel@ sockets.net.

\section{Paper:}

Irshad, A., L.D. Clements, D. Van Dyne. (1997). NonFuel Industrial Uses of Soybean Oilbased Esters and Attachments. NBB Fuel Characteristics/Economics \# 218-0. Jefferson City, MO: National Biodiesel Board. 


\section{Project Title:}

Potential Niche Markets for Biodiesel and their Effects on Agriculture

Background: Biodiesel, a fuel derived from soybean oil or tallow, may be one of the altemative fuels, along with ethanol, compressed natural gas, and methanol, to help government and industry meet requirements of CAAA-90 and the EPAct. Although some studies have looked at the economic feasibility of biodiesel production, little has been done to examine the effects of an expansion of demand for vegetable oil on the agriculture sector. One exception is a study by the University of Missouri. However, this study only examines the effects of a hypothetical increase in the demand for soybean oil without attempting to estimate the potential expansion in demand caused by the creation of niche markets. This paper, therefore, examines potential niche markets for biodiesel if a $20 \%$ biodiesel blend becomes a competitively alternative fuel, and estimates how the increase in soybean oil demand will affect U.S. vegetable oil prices, commodity markets, and farm income.

\section{Objectives:}

- Estimate possible biodiesel demand in three niche markets the biodiesel industry has identified as candidates for commercialization: federal fleets, mining, and marine/estuary areas.

\section{Status: Completed}

Accomplishments:

- Quantified the likely impact on the U.S. agricultural sector if niche markets for biodiesel should develop.

- Found that higher soybean prices would lead to higher cash receipts for crops; lower farm prices for livestock would result in lower cash receipts for these products.

Participants: U.S. Department of Agriculture-Economic Research Service

Sponsoring Organization(s): U.S. Department of Agriculture-Economic Research Service

Point of Contact: Anton Raneses, U.S. Department of Agriculture-Economic Research Service, Washington, DC

Paper Title:

Raneses, A.R.; Glaser, L.K.; Price, J.M. (1996). "Potential Niche Markets for Biodiesel and Their Effects on Agriculture". Proceedings of the Third Liquid Fuels Conference, September 15-17, Nashville, TN. Liquid Fuels and Industrial Products from Renewable Resources, pp. 358-365. 


\section{Project Title:}

Biodiesel Research Progress: 1992-1997

Background: Biodiesel research has expanded to many organizations in recent years, and the effort of determining who is doing what remains to be done and is a very time consuming effort for the industry research groups. Providing a concise summary of projects and contacts in one location may aid in the development of future research.

\section{Objectives:}

- Improve coordination and to focus future research.

- Develop summaries of biodiesel research during the past 5 years.

Status: Project is approximately $95 \%$ finished and is undergoing final peer review.

Accomplishments: More than 300 projects have been located on biodiesel research. Draft reports have been sent to NREL.

Participants: DynCorp, Information Resources, Inc., and National Renewable Energy Laboratory

Sponsoring Organization(s): U.S. Department of Energy Office of Fuels Development

Point of Contact: Dr. K. Shaine Tyson, National Renewable Energy Laboratory, 1617 Cole Blvd., Golden, CO 80401, phone 303.275.4616; fax 303.275.4675, e-mail

tysonk@tcplink.nrel.gov.

\section{Papers:}

Biodiesel Research Progress: 1992-1997. Forthcoming 1998. K. Shaine Tyson, Jill Hamilton, Janine Finnell. National Renewable Energy Laboratory, Golden, CO. 


\section{Project Title:}

University of Southem Indiana Biodiesel Use

Background: Industries in the State of Indiana designed this project in an effort to further the use of biodiesel.

Objective: To use biodiesel or soydiesel as a way to improve emissions from diesel equipment at the University of Southem Indiana.

Status: January 1996-present

Accomplishments:

- Project operating at Southem Indiana University since early 1996.

- A $20 \%$ biodiesel blend is being used in all diesel equipment, including tractors and a forklift.

- Posey County, Indiana Co-op blends 10,000 gallons of biodiesel with diesel fuel annually.

- Indiana Soy Growers Association financed $\$ 0.06$ for every gallon of biodiesel.

Participants: University of Southern Indiana, Posey County Farm Co-op, Soy Growers Association

Sponsoring Organization(s): Posey County Co-op, Farm Bureau, University of Southem Indiana, Soy Growers Association

Point of Contact: Randy Smith, Indiana Soybean Association, phone 800.735.0195, fax 765.482.0992. Steve Selby, University of Southem Indiana, phone 812.464.1876; James Swinney, general manager, Co-op, phone 812.838.4468.

Paper: None available at this time. 


\section{Fuel Distribution}

Also see the following projects: 


\section{Project Title:}

\section{Biofuels Infrastructure Development}

Background: Currently, the availability of biofuel refueling facilities is a barrier to expanded use of biofuels in the Northeast. This project will be a follow-up to an NRBP-sponsored forum on how best to increase the number of biofuel refueling facilities.

Objective: To facilitate the expansion of biofuel use by increasing the number of biofuel refueling facilities in the Northeast.

Status: This project will begin in the summer of 1997

Accomplishments: In progress.

Participants: Individual states in the region as well as the biofuels industry.

Sponsoring Organization(s): Northeast Regional Biomass Program

Point of Contact: Richard Handley, Northeast Regional Biomass Program, CONEG Policy Research Center, Inc., 400 N. Capitol St., Suite 382, Washington, DC 20001, phone 518.899.9572, fax 518.899.9574, e-mail thandley@ capital.net.

Papers: None available at this time. 
Project Title:

Chesapeake Bay Marine Market Biodiesel Use Program

Background: This project was designed to increase use of biodiesel in marine engines, to promote biodiesel awareness. and to reduce pollution in the Chesapeake Bay. Additionally, NBB's Industry Task Force identified fuel cost and retail availability of biodiesel as a barrier to increased use in marine markets.

\section{Objectives:}

- Create a climate conducive to successful retail marine sales of biodiesel, particularly soybased biodiesel, in Maryland and the Chesapeake region

- Promote the awareness of biodiesel to the recreational boating community.

- Distribute biodiesel throughout the Chesapeake Bay area.

Status: Project ran for 3 years

\section{Accomplishments:}

- Recreational boaters were exposed to biodiesel through a series of media activities (Annapolis Boat Show, press events, banners, brochures). The press materials were designed to increase their awareness on the use and benefits of biodiesel.

- Created the most comprehensive document possible pertaining to shipping and handling, marketing, use, environmental impact, and regulatory handling of biodiesel (soydiesel).

- Coastal Properties Management marketed biodiesel (produced by NOPEC Corp.) at eight marina locations throughout the bay area. This involved the placement of refueling tanks at each site.

Participants: BOAT/USA; Agri-Media Services; Chesapeake Bay Foundation; Clean Water Trust; Coastal Properties Management; Cyphers, Wood, Winberg \& Lambird; Maryland Departments of Agriculture, Environment and Natural Resources; Maryland Soybean Board; National Biodiesel Board; NOPEC Corp.; and U.S. Coast Guard

Sponsoring Organization(s): Maryland Soybean Board,; Maryland Departments of Agriculture, Environment and Natural Resources, and National Biodiesel Board

Point of Contact: Glen Holland, Chairman, Promotion Committee, Sandy David, Executive Director, Maryland Soybean Board, P.O. Box 319, Salisbury, MD, 21803, phone 410.742.9500. Bruce Hotchkiss, Agriculture Media Services, PO Box 2026, Easton, MD 21601, phone 410.819.3344.

\section{Paper:}

Final Report: Chesapeake Bay Marine Market Biodiesel Use Program, published February 1997. Press Release. 


\section{Project Title:}

\section{Demonstration Fuel}

Background: This project was initiated to provide potential users with test samples of biodiesel. This was an effort to promote the viability of biodiesel and simulate interest in the fuel.

Objective: Donated various sizes of samples, mostly 5 and 55 gallon sizes to entities and individuals interested in evaluating biodiesel's performance in their application, including mass transit, marine and the like.

Status: Continuous

Accomplishments: Biodiesel has been demonstrated in dozens of fleets nationwide because of this project. For a complete listing of the fleets, contact the NBB.

Participants: National Biodiesel Board, various biodiesel fuel suppliers and interested fleets

Sponsoring Organization(s): National Biodiesel Board

Point of Contact: Ms. Bev Thessen, National Biodiesel Board, P.O. Box 104898, Jefferson City, MO 65110-4898, phone 573.635.3893, fax 573.635.7913, e-mail biodiesel@ sockets.net.

Paper(s): None 


\section{Project Title:}

Marine Biodiesel and Education Project for San Francisco Bay and Northem Califomia

Background: This project involves the establishment of a fuel distribution and marketing infrastructure for biodiesel in Califomia's recreational marine market.

Objectives:

- Promote the sales of biodiesel in the Califomia recreational marine market by supporting the activities of a local contractor who shall establish fuel docks and other elements of a marketing infrastructure of biodiesel.

- Purchase as many as 4,000 gallons of biodiesel and analyze biodiesel samples as available from current biodiesel producers.

- Conduct a review of federal, state and local restrictive regulations pertaining to storage, handling, and dispensing of all fuels (HCs) at designated or permitted fuel docks at marinas, yacht clubs, and other locations suitable for recreational boats.

- Educate boaters and fuel dock distributors by developing a handbook, pamphlet, and presentation on biodiesel information.

- Establish at least five distributorships for retail sales at a new or current retail fuel docks targeted and promoted primarily for recreational boaters.

- Survey as many as 100 current biodiesel users in Northem California for feedback on satisfaction, observations, and possible problems associated with the use of biodiesel in their boats.

Status: Draft reports submitted.

Accomplishments: Work in progress.

Participants: Cytoculture International, Inc. and National Renewable Energy Laboratory Sponsoring Organization(s): U.S. Department of Energy Office of Fuels Development

Point of Contact: Dr. K. Shaine Tyson, National Renewable Energy Laboratory, 1617 Cole Blvd., Golden, CO 80401, phone 303.275.4616, fax 303.275.4675, e-mail tysonk@tcplink.nrel.gov.

\section{Papers:}

Report on Fuel Dock Environmental Tax Regulations (forthcoming)

Technical Handbook on Marine Biodiesel (forthcoming)

Biodiesel Information for Boaters (forthcoming)

Report on Use of Marine Biodiesel in Recreational Boats (forthcoming) 


\section{Project Title:}

Marine Biodiesel Use and Education

Background: Promote and sell biodiesel to boaters in San Francisco Bay.

Objectives:

- Promote biodiesel with the hope to develop a niche market.

- Create consumer awareness.

Status: October 1993-March 1997

Accomplishments:

- Private company is selling biodiesel to about 250 private boaters in the San Francisco Bay.

- Over 3 years the company has sold 3,000 gallons at $\$ 5.00 /$ gal.

- Now selling as a fuel additive (methyl ester).

- Participants: AEP and other Midwest companies, now purchasing waste fry oil from NOPEC.

Sponsoring Organization(s): U.S. Department of Energy, Cytoculture Environmental Inc.

Point of Contact: Dr. K. Shaine Tyson, National Renewable Energy Laboratory, 1617 Cole Blvd., Golden, CO, 80401-3393, phone 303.275.4616, fax 303.275.4675, e-mail tysonk@tcplink.nrel.gov.

Paper: None available at this time. 


\section{Project Title:}

Pennsylvania Heavy Vehicle Study

Background: Pennsylvania State officials were interested in determining how heavy- and light-duty equipment operates on biodiesel blends as a potential clean buming and domestic energy source.

Objective: To test a number of vehicle classes on a variety of biodiesel blends during two seasons.

Status: July 1996-October 1996 (3-month study)

Accomplishments:

Vehicles at two locations were tested on a variety of biodiesel blends:

- Fifteen heavy vehicle (dump trucks)

- Four light duty vehicles

- Five other pieces of equipment.

Participants: Pennsylvania Tumpike Commission

Sponsoring Organization(s): National Renewable Energy Laboratory and Pennsylvania Tumpike Commission

Point of Contact: Sue Summers and Michael McClurkan of the Pennsylvania Tumpike Commission, P.O. Box 67676, Harrisburg, PA 17106-7676, phone 717.772.8944 (Sue), phone 717.939.9551 (Michael).

Paper: None 


\section{Project Title:}

Regulated Fleets Marketing Assistance and Physically Market the Fuel

Background: NBB identified EPAct-regulated fleets as a viable market for biodiesel. This project was designed to create distribution channels to successfully commercialize biodiesel, including the development of a strong partnerships or relations with key petroleum suppliers.

Objective: This project was designed to:

- Actively promote and/or distribute biodiesel with five biodiesel marketers.

- Include biodiesel in five state EPAct compliance strategies.

- Meet with at least 10 major oil companies, pipeline companies, or distribution companies where specific information on biodiesel is provided.

- Involve three agricultural /cooperative oil companies in the distribution of biodiesel.

- Focus on selling the fuel and creating sales opportunities for the industry fuel suppliers;

- Build closer relationships with suppliers, marketing must control media, presentations, and product development strategies.

- Improve awareness of geographic and demographic strengths available to the suppliers.

Status: August 1, 1995-August 31, 1997 (continuous)

Accomplishments: Under this project, NBB:

- Supports the low blend market strategy.

- Established three petroleum/chemical distributors to work with NBB suppliers to attempt successful packaging/distribution of methyl esters downstream.

- Is positioned to collaborate with West Coast mariner/businessman to create a distribution system in Marina Del Ray for niche marine fuel and fuel supplement applications.

- Worked on low blend lubricity/combustion improver to determine actual performance and economic viability.

- Served as a conduit between OPIS and the reading public on biodiesel issues.

- B20 is positionedfor national market locations, pending the regulatory petition approval, using pipeline infrastructure and selected wet barrel supplier.

Participants: Advanced Fuel Solutions

Sponsoring Organization(s): National Biodiesel Board, Minnesota Soybean Board, and the United Soybean Board

Point of Contact: Paul Nazarro, Advanced Fuel Solutions, P.O. Box 291, Lynnfield, MA 01940, phone 508.664.5923, fax 508.664.4020.

Paper: None 


\section{Project Title:}

Rhode Island Energy Office Education Program with Pleasure Craft

Background: To familiarize the boating public with biodiesel fuel, the Rhode Island Energy Office is sponsoring activities to offer biodiesel through marina fuel stations.

Objective: To have biodiesel considered as an altemative fuel by marinas in select parts of Rhode Island.

Status: April 1997-September 1997

Accomplishments: Ongoing

Participants: Rhode Island Energy Office

Sponsoring Organization(s): Northeast Regional Biomass Program

Point of Contact: Julie Capobianco, Department of Administration, Division of Central Services, Rhode Island State Energy Office, 1 Capitol Hill, Providence, RI 02908, phone 401.222.3370, fax 401.222.1260.

Papers: None available at this time. 


\section{Project Title:}

State of Massachusetts Commuter Boat Operation in Boston Harbor

Background: The marine market has been identified by the biodiesel community as one with significant potential sales because of the relative cost of diesel fuel and the environmental benefits of biodiesel. This project was designed to raise public awareness of biodiesel use in marine applications and to test the market.

Objectives:

- Begin distribution of biodiesel in a marine market.

- Test a $20 \%$ biodiesel blend on boats.

- Further evaluate the potential of biodiesel sales in the marine market.

Status: June 1996-October 1996.

Accomplishments:

- TRT began distribution of biodiesel to the City of Boston during the summer of 1996 for use in commuter boats.

- The city used 15,000 gallons of biodiesel during the 4-month period.

Participants: Twin Rivers Technologies, Inc., City of Boston

Sponsoring Organization(s): City of Boston

Point of Contact: Gene Gebolys, Vice President, Alternative Fuels Division, Twin Rivers Technologies, Inc., 780 Washington Street, Quincy, MA 02169, phone 617.472.9200.

Paper: None 
Project Title:

Washington State Biodiesel Use in the Puget Sound

Background: The project is intended to educate people on biodiesel use in marine applications and to promote the fuel through long term use in environmentally sensitive areas.

Objective: To provide biodiesel for boats operated by groups who patrol the Puget Sound and other Washington waterways.

\section{Status: Ongoing}

Accomplishments:

- Working with Puget Sound Keepers, an environmental educational group that does water quality workshops in Seattle marinas.

- The Energy Office is waiting for the group's boat to be repaired before any discussions will take place.

- Currently looking at other organizations.

Participants: Puget Sound Keepers, Washington State Energy Office

Sponsoring Organization(s): Washington State University, Washington State Energy Office

Point of Contact: Kim Lyons, State University Energy Office, 925 Plum Street, SE, Building 4, Olympia, WA 98504-3165, phone 360.956.2083, fax 360.956.2217.

Paper: None available at this time. 


\title{
VII. Economics and Environment
}

\author{
A. Economic Research
}

Also see the following projects:

Assessment of the Potential for Biodiesel Rapeseed Production in the Southeast

Bi-State Development Agency Altemative Fuel Bus Testing of 10 Buses

Rapeseed Oil as a Fuel for Agriculture 


\section{Project Title:}

\section{A Proposed Biodiesel Development Plan}

Background: In order to create economically viable and sustainable markets for renewable fats and oils, a focused research program is necessary. This program needs to be directed at lowering the cost of production, expanding the resource base, optimizing the properties of biodiesel feedstocks, and developing environmentally benign production, conversion, and utilization technologies that take advantage of the unique properties of fats and oils. At the same time, agricultural land use policy and competition for land needed for food, fiber, and other industrial uses could severely limit the potential to achieve a significant level of biodiesel production. These factors require a longer-term outlook for biodiesel.

Objective: To describe where biodiesel is at today. It recommends both economic and scientific research to advance the commercialization of biodiesel.

Status: Initiated in FY 1996; ongoing effort

Accomplishments: A Biodiesel Development Plan has been developed. This document is considered a "living document" in that it is being revised on an ongoing basis as new information becomes available.

Participants: Colorado Institute for Fuels and High Altitude Engine Research, Colorado School of Mines

Sponsoring Organization(s): USDA-ERS, Office of Energy and New Uses

Point of Contact: Dr. James Duffield, Agricultural Economist, USDAERS, 1301 New York Avenue, NW, Washington, DC 20005, phone 202.501.6255, fax 202.501.6338.

\section{Papers:}

Conway, R.K.; Duffield, J.A.; Graboski, M.S. (1996). A Proposed Biodiesel Development Plan. Available through the Office of Energy and New Uses; Economic Research Service, U.S. Department of Agriculture. 


\section{Project Title:}

An Analysis of Economic and Environmental Impacts of Using Biodiesel in the Kansas City Metropolitan Area

Background: Under clean air regulations, alternative fuels are needed to help diesel engines to met more stringent air quality standards. Mandates for cleaner air in metropolitan areas provides an opportunity for biodiesel or biodiesel blends to substitute for No. 2 diesel fuel. From experimental data, the emissions of diesel engines from various diesel/soy oil blends show reduction in pollutants when compared to pure petroleum diesel.

\section{Objectives:}

- Evaluate the environmental cost of reducing air pollution by using blends of biodiesel and diesel fuel in the Kansas City metropolitan area.

- Estimate the potential demand for biodiesel and capacity needed to supply soil based biodiesel.

- Evaluate job creation and the added income from a potential biodiesel industry in the Kansas City area and the United States as a whole.

- Analyze the impacts on the agricultural sector of using biodiesel, as well as the effects on soybean oil, soybean meal, and soybean markets when the oil is used as an altemative stock for biodiesel production.

\section{Status: December 1994}

Accomplishments: Research results found:

- Significant savings of environmental costs in PM, CO, and $\mathrm{HC}$ by using biodiesel on level 3.

- Increased job creation in an expanded biodiesel industry will be substantial while job loss in the petroleum industry will be minute.

Participants: University of Missouri

Sponsoring Organization(s): University of Missouri

Point of Contact: Melvin G. Blase, Dissertation Supervisor, University of Missouri-Columbia, Columbia, MO 65211.

Paper(s):

Chang, R. (1994). An Analysis of Economic and Environmental Impacts of Using Biodiesel in The Kansas City Metropolitan Area. Ph.D. Dissertation. Colombia, MO: University of MissouriColumbia. 


\section{Project Title:}

Assessment of the Potential for Biodiesel Rapeseed Production in the Southeast

Background: To better ascertain rapeseed availability, it was believed that a comprehensive assessment would be a useful starting point.

Objective: To establish the conditions, availability, and economics of producing biodiesel from rapeseed.

Status: March 1, 1992-June 2, 1993

\section{Accomplishments:}

- It was concluded that rapeseed can be an important tool to improve crop rotation, soil conservation, and use of idle land.

- Production costs require farm subsidies or an increase in petroleum prices to be cost competitive with petroleum diesel.

Participants: University of Missouri, University of Georgia, Southeast Regional Biomass Energy Program

Sponsoring Organization(s): Southeast Regional Biomass Energy Program

Point of Contact: Donald Van Dyne, University of Missouri, Columbia, MO 65211, phone 573.882.0141.

Papers:

Van Dyne, D.L. and P.L. Raymer (1992). Final Contract Report: Biodiesel Production Potential from Industrial Rapeseed in the Southeastem U.S. Published by SERBEP. 


\section{Project Title:}

Biodiesel From Canola: An Economic Feasibility Analysis

Background: The number of crops available for field production in dryland farming areas of northem Idaho and eastem Washington are limited to grain or grain-legume rotations. One or more new crops, which would fit into a rotation with the existing ones, would be welcome. Rapeseed crops have been grown in the Pacific Northwest with varying degrees of success. Industrial type winter rapeseed has been grown in the Pacific Northwest for many years.

Spring canola is a new crop. Either of these oils can be used as a feedstock for biodiesel. This study concentrated on canola oil for biodiesel use because that was the predominant oilseed in the study area.

\section{Objectives:}

- Estimate the cost of providing biodiesel produced from canola oil for the Spokane Transit Authority.

- Select a plant site and make cost estimates for the least cost location.

Status: Completed

\section{Accomplishments:}

- Using canola oil, a gallon of biodiesel still costs more than a gallon of petroleum oil.

- Blended fuels afford many of the advantages of biodiesel at a much lower cost than straight biodiesel.

- Except for specialized uses, a less expensive feedstock will be needed to make biodiesel a competitive fuel.

Participants: University of Idaho

Sponsoring Organization(s): University of Idaho

Point of Contact: Dr. Charles Peterson, Department of Agricultural Engineering, University of Idaho, Moscow, ID 83844, phone 208.885.7906, fax 208.885.8923, e-mail

peterson@novell.uidaho.edu.

\section{Paper Title:}

Withers, R. V.; Noordam, M. (1996). "Biodiesel from Canola: An Economic Feasibility Analysis." Proceedings of the Third Liquid Fuels Conference, September 15-17, Nashville, TN. Liquid Fuels and Industrial Products from Renewable Resources, pp. 366-375. 


\section{Project Title:}

Biodiesel: Potential Economic Benefits to lowa and lowa Soybean Producers

Background: The cost and success of biodiesel depend heavily on soybean oil prices, which in tum are related to soybean production and soybean/soybean meal demand. The purpose of this project is to evaluate the economic benefits of biodiesel to lowa soybean producers.

\section{Objectives:}

- Determine whether it makes sense for lowa's taxpayers to finance biodiesel purchases for the state's vehicle fleet.

- Evaluate the advantages and disadvantages to lowa soybean producers for participating in these types of programs.

- Look at the short- and medium-term outlook for soybean oil production and prices.

- Evaluate the benefits and costs to lowa soybean producers of becoming involved in the legislative changes required to create a state-funded biodiesel market in lowa.

Status: September 1995

Accomplishments:

- The study findings are more supportive of the state's participation in the biodiesel market than for soybean producer participation.

- If plans to build a biodiesel plant in lowa can be positively influenced by the state's participation in the biodiesel process, the biodiesel policy clearly makes sense.

Participants: lowa State University, lowa Soybean Promotion Board

Sponsoring Organization(s): lowa Soybean Promotion Board

Point of Contact: Dermot J. Hayes, Trade and Agricultural Policy Research Division, Center for Agricultural and Rural Development, lowa State University, Ames, IA 50011, phone 515.294.1423.

\section{Paper:}

Hayes, D.J. (1995). Biodiesel: Potential Economic Benefits to lowa and lowa Soybean Producers. Ames, IA: lowa Soybean Promotion Board. Work performed by lowa State University, Ames, IA. 


\section{Project Title:}

\section{Biodiesel Research 1996 and Beyond}

Background: A combination of factors has pushed energy from biomass into the forefront of policy and industry discussions. Large harvests of traditional crops, dependence on foreign energy sources and environmental problems have increased interest in renewable energy sources. The qualities of biodiesel have pushed it closer to the final stages of commercialization in the United States. NBB is a major driving force behind the efforts to commercialize biodiesel in the United States. They have approved a systematic approach geared towards identifying the prospect for biodiesel.

Objectives: This project was designed to direct the Board on future research projects. The objectives were to:

- Provide an overview of the need for a systematic and sustained approach to conduct biodiesel research.

- Describe the systematic and sustained approach for biodiesel research that has been adopted by NBB to facilitate the commercialization of biodiesel in the United States.

- Discuss the basic research needed by the biodiesel industry before biodiesel is commercialized in the United States.

- Discuss the applied research needed by the biodiesel industry before biodiesel is commercialized in the United States.

Status: 1996

\section{Accomplishments:}

- Generated a systematic and sustained biodiesel research agenda.

- Determined basic research needs designed to facilitate biodiesel sales in general.

- Discussed applied research needs based on niche markets such as aviation, marine, and underground mining.

Participants: MARC-IV Consulting and the University of Missouri-Columbia

Sponsoring Organization(s): National Biodiesel Board

Point of Contact: Ms. Bev Thessen, National Biodiesel Board, PO Box 104898, Jefferson City, MO, 65110-4898, phone 573-635-3893, fax 573-635-7913; e-mail biodiesel@sockets.net; Mr. Steve Howell, MARC-IV Consulting, Inc., 16200 Northridge Road, Kearney, MO, 64060, phone 816-635-5772, fax 816-635-4836, e-mail showell @ marciv.com.

\section{Paper(s):}

Schumacher, L.G.; Howell, S.; Weber, J.A. (1996). "Biodiesel Research - 1996 and Beyond." Proceedings of the Third Liquid Fuel Conference, September 15-17, Nashville, TN, pp 217224. 


\section{Project Title:}

Compare Life Cycle Costs of Altemative Fuels (Biodiesel, Compressed Natural Gas, and Methanol in Urban Buses)

Background: Because of stricter environmental regulations, the market for domestic altemative fuels is becoming more important. However, there is a gap in the literature comparing the costs of these fuels. This project provides a cost comparison for operating a transit-bus fleet on three altemative fuels--biodiesel, CNG, and methanol.

Objectives: The purpose of the project was to provide an expected cost comparison for operating a transit-bus fleet on three altemative fuels--biodiesel, CNG, and methanol.

Petroleum diesel is the base fuel. Infrastructure, refueling, and maintenance costs are all part of running an urban transit bus. Additional expenditures would be needed to change fuel storage and delivery systems, as well as bus engines and fuel systems, to use methanol or CNG.

Status: FY 1994-1995

Accomplishments:

- Using a $5 \%$ discount rate, the present value per bus mile was calculated for the total cost (the sum of infrastructure, bus alteration, refueling, and maintenance expenses) of a transit fleet over the estimated 3-year life cycle of a refueling infrastructure. Diesel buses has the lowest cost at $\$ 0.247 / \mathrm{mi}$. As biodiesel is blended with diesel, the cost per mile ranged from $\$ 0.279$ to $\$ 0.475$ depending on the amount of biodiesel used and its estimated price. CNG's cost varied from $\$ 0.375$ to $\$ 0.42 / \mathrm{mi}$; methanol's cost was $\$ 0.736 / \mathrm{mi}$.

- The analysis indicated that, although biodiesel and biodiesel blends have higher total costs than diesel fuel, they have the potential to compete with CNG and methanol as fuels for urban transit buses.

Participants: Department of Agricultural and Applied Economics, University of Georgia, U.S. Department of Agriculture-Economic Research Service/Office of Energy and New Uses

Sponsoring Organizations(s): U.S. Department of Agriculture-Economic Research Service/Office of Energy and New Uses

Point of Contact: Dr. James A. Duffield, USDA-ERS/OENU, 1301 New York Ave, NW, Room 1212, Washington, DC 20005, phone 202.501.6255, fax 202.501.6883

\section{Papers:}

Ahouissoussi, Nicolas B.C. and Michael E. Wetzstein (1995). Life Cycle Costs of Altemative Fuels: Is Biodiesel Cost Competitive for Urban Buses? Industrial Uses/IUS-5S/November. U.S. Department of Agriculture-Economic Research Service.

Ahouissoussi, N.B.C.; Wetzstein, M.E. (1996). "Biodiesel Cost Comparison for Urban Buses." Proceedings of the Third Liquid Fuels Conference, September 15-17, Nashville, TN. Liquid Fuels and Industrial Products from Renewable Resources, pp. 336-349. 


\section{Project Title:}

Conversion of Glycerol from SoyDiesel Production to 1,3 Propanediol

Background: This project is made to increase glycerin value and decrease biodiesel costs.

Objective: To develop a fermentation process for the production of 1,3 propanediol from the crude glycerol stream of a biodiesel facility.

Status: November 1994

Accomplishments:

- Inexpensive nitrogen sources such as soybean meal and ammonia water are practical for fermentation.

- Glycerol concentrations should be maintained at low levels for good productivity.

- Researchers achieved successful synthesis of poly (trimethylene terephthalate) with modest molecular weights.

Participants: University of Wisconsin-Madison

Sponsoring Organization(s): National Biodiesel Board

Point of Contact: Ms. Bev Thessen, National Biodiesel Board, P.O. Box 104898, Jefferson City, MO 65110-4898, phone 573.635.3893, fax 573.635.7913, e-mail biodiesel @ sockets.net. Douglas Cameron and James Koutsky, Department of Chemical Engineering, UW-Madison, Madison, WI 53706-1691.

\section{Paper:}

Cameron, D.C.; Koutsky, J.A. (1994). Conversion of Glycerol from SoyDiesel Production to 1,3 Propanediol. Madison, WI: Department of Chemical Engineering, University of Wisconsin. Available from the National Biodiesel Board, Jefferson City, MO 65110. 


\section{Project Titie:}

Economic Impacts of Biodiesel use in a Midwestem State Vehicle Fleet

Background: Energy security issues have prompted legislation and regulatory actions spurring demand for altemative fuels such as biodiesel. Specifically, the U.S. Congress and many state governments have passed legislative actions that address both environmental and energy security issues through the purchase of AFVs. At the national level, state fleets must meet AFV purchase requirements of EPAct. At the state level, Missouri state agencies must meet the Fuel Conservation for State Vehicles Program that also requires the purchase of AFVs. Regarding implementation, state energy officials must be able to meet state and federal regulations in a period of stagnant budgets. Fleet managers must be assured about performance and operating issues, associated with the use of altemative fuels. Thus, state governments must find cost-effective, reliable compliance strategies.

Objective: To explore the economic implications of using biodiesel in a state vehicle fleet.

Status: Completed

\section{Accomplishments:}

- Researchers found that state fleets have an opportunity to purchase biodiesel FFVs, use a low percent biodiesel blend, and create economic development opportunities within the state by selecting biodiesel as their energy policy compliance strategy.

- Researchers believed that OEMs must provide engine warranties for biodiesel vehicles to make biodiesel more competitive.

- They suggested that DOE certify B20 blends as an altemative fuel.

Participants: MARC-IV Consulting, Inc. and University of Missouri

Sponsoring Organization(s): MARC-IV Consulting, Inc.

Point of Contact: Alan Weber, MARC-IV Consulting Inc., 402 Oak Street, Ashland, MO 65010, phone 573.657.5537, fax 573.657.1058, e-mail aweber@marciv.com.

Paper(s):

Weber, J.A.; Van Dyne, D.L. (1996). "Economic Impacts of Biodiesel use in a Midwestem State Vehicle Fleet". Proceedings of the Third Liquid Fuels Conference, September 15-17, Nashville, TN. Liquid Fuels and Industrial Products from Renewable Resources, pp. 328-335. 


\section{Project Title:}

Estimating Price and Nonprice Impact of Producing Biomass on CRP Acreage

Background: Various levels of CRP land planted to different types of biomass crops were studied. The 1992 National Resources Inventory database was used to identify characteristics of CRP land, including potential soil erosion when producing various biomass crops.

Microeconomic impacts of biomass for bioenergy was estimated using IMPLAN, an inputoutput model. It measured changes in jobs, investment, economic activity, and other relevant factors with additional crop production and processing plants located in rural areas. Impacts of biomass for bioenergy on traditional agriculture, exports, imports and the general economy was measured by the models developed by the Food and Agricultural Policy Research Institute (FAPRI). A component of the project involved biodiesel and involved modifying FAPRI models to include coproducts, such as meal from oilseeds produced for use as a fuel. It integrated crop and livestock production, and included estimated changes in imports, exports, and other relevant factors as the result of producing biomass for biofuels on CRP acreage.

\section{Objectives:}

- Estimate aggregate levels costs and benefits of producing biomass for use as biofuels on idled CRP acreage.

- Estimate the environmental impacts of producing biomass for use as biofuels on idled CRP acreage.

Status: July 1994-June 1996.

\section{Accomplishments:}

- This research has evaluated the potential impacts of producing energy crops on CRP lands and then converting them into various types of energy.

- It provided estimates of the volumes of different types of energy (ethanol, biodiesel, plus woody and plant biomass) that could be produced.

- It also provided estimates of macroeconomic impacts (jobs, investment, increased personal income, and increased economic activity in rural communities).

- Lastly, it provided estimates of the volume of carbon that could be sequestered in the energy crops.

Participants: Social Science, University of Missouri, U.S. Department of AgricultureCooperative State Research, Education, and Extension Service

Sponsoring Organization(s): U.S. Department of Agriculture-Cooperative State Research, Education, and Extension Service

Point of Contact: Donald L. Van Dyne, Social Science, University of Missouri, Columbia, MO 65211, phone 573.882.0141.

\section{Papers:}

Weber, J.A. and D.L. Van Dyne (1996). "Economic Impacts Of Biodiesel use in a Midwestem State Vehicle Fleet." Proceedings American Society of Agricultural Engineers, pp. 328-335.

Van Dyne, D.L., J.A. Weber, and C. Braschler (1996). "Macroeconomic Effects of a Community-Based Biodiesel Production System." Bioresource Technology 56(I):1-6. 
Van Dyne, D.L., C. Braschler, and M.G. Blase (1996). "Macroeconomic and Fiscal Impacts of a 57 Million Liter Com-to-Ethanol Plant in North Missouri." Proceedings American Society of Agricultural Engineers, pp. 311-318.

Additional Information: CRIS Accession No.: 9166308. 


\section{Project Title:}

\section{Fuel Road Tax Investigation}

Background: One aspect to developing biodiesel as a motor fuel is understanding the economics of the fuel, including tax issues. This project was initiated to better understand tax issues affecting biodiesel.

Objectives: This was a study completed on the federal tax liability of biodiesel and determined that road taxes should be paid by the fuel suppliers. A state tax study was also completed.

Status: Complete.

Accomplishments: Report complete in 1994.

Participants: Information Resources, Inc.

Sponsoring Organization(s): National Biodiesel Board

Point of Contact: Ms. Bev Thessen, National Biodiesel Board, P.O. Box 104898, Jefferson City, MO, 65110-4898, phone 573.635.3893, fax 573.635.7913, e-mail biodiesel @ sockets.net.

Paper(s):

Fuel Road Tax Investigation. (1994). Prepared for the National Biodiesel Board, Jefferson City, MO. 


\section{Project Title:}

Industrial Products from Agricultural Resources

Background: This project evaluates the most promising technologies and industrial products that could be produced from crops and livestock, including those products and coproducts currently produced or those that could be produced in Missouri. Initial emphasis will be on those products produced from the erucic acid of crambe and/or industrial rapeseed.

\section{Objectives:}

- Identify and evaluate the most promising industrial products that can be made from agricultural products and coproducts in Missouri.

- Develop a strategy for commercializing industrial products that would provide the greatest opportunity for economic development in rural communities.

Status: July 1991-December 1993.

Accomplishments: This engineering/economic study estimated that biodiesel produced from soybeans could be produced in community-based plants for a residual cost of $\$ 1.26 / \mathrm{gal}$. This assumes that farmers produce soybeans, hire the local plant to process them, and then use the fuel and high protein feed on their own farms. This assumes farmers value soybeans at $\$ 5.60 /$ bu and high-energy meal at $\$ 220 /$ ton. If meal value is $\$ 240$, then residual biodiesel cost is $\$ 0.62 / \mathrm{gal}$. Instead of processing vegetable oils into biodiesel, farmers may be financially better off to sell the oil on the open market. In this analysis, marketing margins, profit, risk charges, and other business costs are not included.

Participants: Social Sciences, University of Missouri, U.S. Department of AgricultureCooperative State Research, Education, and Extension Service

Sponsoring Organization(s): U.S. Department of Agriculture-Cooperative State Research, Education, and Extension Service

Point of Contact: Donald L. Van Dyne, Social Sciences, University of Missouri, Columbia, MO 65211, phone 573.882.0141.

\section{Papers:}

Weber, J.A. (1993). "The Economic Feasibility of Community Based Biodiesel Plants." M.S. Thesis, University of Missouri-Columbia.

Weber, J.A. (1993). "The Feasibility of Producing Biodiesel in the United States Using a Community-Based Facility in Industrial Uses of Agricultural Materials; Situation and Outlook Report." U.S. Department of Agriculture-Economic Research Senvice, December 1993.

Weber, J.A. and D.L. Van Dyne (1993). "Implications of Federal Policy Decisions on the Production and Use of Biodiesel." Presented at the Association of the Advancement of Industrial Conference Annual Meeting in New Orleans, LA in September, 1993.

Weber, J.A. and D.L. Van Dyne (1993). "Biodiesel Production Potential in Missouri Farm Financial Outlook '94." UMC Extension and Agricultural Economics. 
Weber, J.A. and D.L. Van Dyne (1993). "Cost Implications of Innovative Feedstock Combinations for Biodiesel Production." Poster presented at the First Annual Biomass Conference of the Americas, Burlington, VT, August 28-September 1.

Weber, J.A. and D.L. Van Dyne (1993). "Cost Implications of Feedstock Combinations for Biodiesel Production." Poster presented at the Food for the 21st Century poster presentation on October 28, 1993 at Don Reynolds Alumni Center.

Weber, J.A. (1993). "The Concept of Producing Biodiesel at the Community Level Instead of on an Industrial Scale." Seminar presented at the Food for the 21st Century.

Additional Information: CRIS Accession No.: 9156237 
Project Title:

Life Cycle Cost Education

Background: The State of Massachusetts recently completed a study to show that biodiesel and biodiesel blends can be the least cost option for particulate emission control for urban buses. Quite often, biofuels have not received equal consideration with other altemative fuels such as natural gas and propane. It is argued that although biofuels are more costly than the competing altematives, they can effectively compete on a life cycle basis when infrastructure and vehicle modification costs are factored in.

Objectives: The objective of this project is to educate fleet owners that biofuels are competitive with other altemative fuels on a life cycle basis, thus increasing the amount of ethanol and biodiesel being used as altemative fuels.

Status: Postponed. Still seeking financial partners for this project. NRBP will attempt to incorporate facets of this project in other outreach activities.

Accomplishments:

- NRBP will, through its network of state bioenergy representatives and state biomass programs, set up forums to educate fleet managers on life cycle costs to overcome the entry barrier of biofuels cost.

Participants: Biodiesel industry, Northeast Regional Biomass Program

Sponsoring Organization(s): Northeast Regional Biomass Program

Point of Contact: Rick Richard Handley, Northeast Regional Biomass Program, CONEG Policy Research Center, Inc., 400 N. Capitol St., Suite 382, Washington, DC 20001, phone 518.899.9572, fax 518.899.9574, e-mail thandley@ capital.net

Papers: None available at this time. 


\section{Project Title:}

\section{Biodiesel--Net Energy Study}

Background: Vegetable oil extracted from soybeans are widely used as food and industrial products. Recently soy oil has been processed into a viable substitute for diesel fuel. To aggressively encourage the use of soydiesel the public must be assured that it will constitute a positive addition to our national energy supply. This project involved the analysis from seed to tailpipe of the net energy obtained from biodiesel.

\section{Objectives:}

- Determine how much energy is used to grow the feedstock.

- Determine how much energy is used to extract and refine oil.

- Evaluate the energy used in esterifying the oil.

- Ascertain how much energy is contained in soydiesel and the two coproducts--soy meal and glycerin--produced by these processes.

Status: January 1994

\section{Accomplishments:}

- Researchers concluded that soydiesel is a net energy generator. Therefore, even without assigning any energy value to the two coproducts produced in this process, the soydiesel net energy balanced realized a $44 \%$ net energy gain.

- When energy coproducts are included, the net energy benefits rise.

- Assuming the soybeans are grown by the most energy conserving famer and processed into final products by the most energy-conserving industrial plants, soydiesel's net energy benefit can be as high as 3.24:1.

Participants: Institute for Local Self-Reliance

Sponsoring Organization(s): National Biodiesel Board

Point of Contact: Ms. Bev Thessen, National Biodiesel Board, P.O. Box 104898, Jefferson City, MO, 65110-4898, phone 573.635.3893, fax 573.635.7913, e-mail biodiesel@ sockets.net. Irshad Ahmed, Institute for Local Self-Reliance, 2425 18th Street NW, Washington, DC 20009. 2096, phone 202.232.4108, fax 202.332.0463.

\section{Paper(s):}

Ahmed, l.; Decker, J.; Morris, D. (January 1994). How Much Energy Does It Take to Make a Gallon of SoyDiesel? NBB 4005-2. Jefferson City, MO: National SoyDiesel Development Board. Work Performed by the Institute for Local Self-Reliance, Washington, DC. 


\section{Project Title:}

\section{Mine Economic Study}

Background: NBB identified mining applications as a potential market for biodiesel. The mining industry faces strict air quality and environmental standards. This project was designed to determine if biodiesel is economically competitive with current mining technologies in metal, non-metal, and coal mines.

\section{Objectives:}

- Summarize pending emission regulations and methods for reducing emissions, and develop an exhaustive list of available and pending emission controls that could be used by mine operators during the next 5 years to reduce emissions.

- Evaluate the equipment life cycle costs of converting mine equipment to three presently available emission controls and 1 "soon-to-be-available" control.

- Develop two case study examples of the net value of converting mining equipment to biodiesel versus the most competitive current or potential emission controls.

Status: September 1, 1995-April 1, 1997

\section{Accomplishments:}

- Biodiesel appears to be a viable PM control strategy compared to filter PM control strategies on light-duty equipment. Regenerable fiber coil diesel particulate filters are an expensive option primarily due to capital costs. In addition, light duty vehicles consume less fuel per hour than heavy-duty vehicles therefore decreasing the fuel cost impact of using biodiesel.

- Additional data are presented on various cost and PM reduction scenarios.

- The data are based strictly on economic results and will not take into consideration potential positive operational factors and health impacts of using biodiesel as a PM reduction strategy.

Participants: University of Minnesota, Center for Diesel Research

\section{Sponsoring Organization(s): National Biodiesel Board}

Point of Contact: Ms. Bev Thessen, National Biodiesel Board, P.O. Box 104898, Jefferson City, MO, 65110-4898, phone 573.635.3893, fax 573.635.7913, e-mail biodiesel@sockets.net.. Joseph F. McDonald, Center for Diesel Research, Department of Mechanical Engineering, University of Minnesota, 111 Church Street, SE, Minneapolis, MN 55455-0111, phone 612.725.4750.

\section{Paper:}

"Economic Comparison of Biodiesel Blends to Commercially Available Exhaust Emission Reduction Technologies for Underground Mines." 


\section{Project Title:}

Oilseeds: Commercializing Biodiesel and Other Products

Background: The objective of this program is to develop mainly industrial, altemative uses for products derived from agricultural feedstock that can help use many idle farm and rural resources. A simulation model will be developed that will allow evaluation of the economic feasibility of biodiesel as each of the important variables change. Replicated rapeseed plots will be established in central Missouri to evaluate rotations and management practice interactions. Livestock feeding studies with beef cattle will be used to evaluate rapeseed meal as a feed material.

\section{Objectives:}

- Evaluate the feasibility of producing biodiesel from locally grown oilseeds in selected areas of Missouri, emphasizing costs of transesterification and researching ways to reduce feedstocks including coordination and support to encourage the construction and operation of biodiesel plants in Missouri, and working with the various biodiesel and soybean associations and others to raise awareness of the positive attributes of biodiesel and other higher value products from methyl esters.

- Evaluate the performance and profitability of canola, rapeseed, and sunflowers in various cropping systems.

- Identify the nutritional value of sunflower meal for cattle that will allow the determination of its value added price in the market relative to other commercially available ruminant protein feedstuffs.

Status: April 1994-April 1998.

Accomplishments:

- Evaluated the economic feasibility of using vegetable oil derived-methyl esters (biodiesel) as a diesel fuel substitute/additive

- Identified niche markets where this relatively expensive fuel could compete with traditional fuel, with emphasis on reduced air emissions, nontoxicity, and biodegradability.

- Evaluated the use of methyl esters in other applications such as solvents, drilling muds, etc. Because feedstock cost is a very large portion of the total cost of biodiesel production, it emphasizes a systems approach to reduce feedstock costs and enhance the meal coproduct value, thus resulting in the methyl ester being more competitive.

Participants: Plant Science, University of Missouri

Sponsoring Organization(s): U.S. Department of Agriculture-Cooperative State Research, Education, and Extension Service

Point of Contact: Donald Van Dyne, University of Missouri-Columbia, Columbia, MO 65211, phone 573.882.8237.

\section{Papers:}

Glaser, L., C. Plummer, and D.L. Van Dyne (1996). "Industry Expands Use of Agricultural Commodities." Agricultural Outlook, Economic Research Service/U.S. Department of Agriculture. 
Van Dyne, D.L., C.H. Braschler, and M.G. Blase (1996). "Macroeconomic and Fiscal Impacts of A 57 Million Liter Com-to-Ethanol Plant In North Missouri." Proceedings, American Society of Agricultural Engineers, pp. 311-318.

Weber, J.A. and D.L. Van Dyne (1996). "Economic Impacts of Biodiesel use in a Midwestem State Vehicle Fleet." Proceedings, American Society of Agricultural Engineers, pp. 328-335.

Van Dyne, D.L., J.A. Weber, and C.H. Braschler (1996). "Macroeconomic Effects of a Community-Based Biodiesel Production System." Bioresource Technology, 56(I):I-6.

Additional Information: CRIS Accession No.: 9165193. 


\section{Project Title:}

Soy Diesel Processing Buchanan County, Missouri: Potential Impacts

Background: This paper reports analysis of the potential economic and fiscal impacts of biodiesel production on a metropolitan county in Northwest Missouri. These estimates indicate the magnitude of impacts that one might expect from conversion of soybeans to biodiesel. The assessment is not a feasibility study. The feasibility of products such as biodiesel depends on a myriad of economic variables, technological and scale issues, and assumptions about environmental health and safety regulations.

Objective: To analyze the potential economic and fiscal impacts of biodiesel production in a Missouri community.

Status: Completed

\section{Accomplishments:}

- Biodiesel production, if well integrated into the existing economic base, appears to offer significant benefits to areas such as Northwest Missouri.

- Biodiesel fits into a well-designed economic development strategy like that of Buchanan County.

- An industry such as this can have far reaching impacts in terms of the sustainability and viability of other local sectors.

Participants: University of Missouri, Rural Policy Research Institute

Sponsoring Organization(s): University of Missouri

Point of Contact: Jian Ma, Economist and Research Associate, Rural Policy Research Institute, University of Missouri-Columbia, Columbia, MO 65211.

Paper Title:

Ma, J.C.; Scott, J.K.; Johnson, T.G. (1996). "Soy Diesel Processing in Buchanan County, Missouri: Potential Impacts" Proceedings of the Third Liquid Fuels Conference, September 1517, 1996, Nashville, TN. Liquid Fuels and Industrial Products from Renewable Resources, pp. 319-327. 
Project Title:

Tax Incentive Study

Background: The study examined the viability of tax incentives in relation to biodiesel's cost and competitiveness in the market place. There is now a large body of data and reports on the technologies for the production of one class of oxygen containing seed oil-based fuels and on the performance of compression ignition engines using these fuels. This material has been used to investigate the economics of the new diesel fuels and the tax incentives that might be made available to improve the economics of their production, distribution, and use in diesel engines.

\section{Objectives:}

- Examine tax concessions potentially available from federal or state agencies for the use of biodiesel.

- Quantify the benefits of biodiesel by reference to the costs of altemative ways to reduce emissions of particulates, $\mathrm{NO}_{x}, \mathrm{CO}$, and sulfur oxides priced by the electric utilities.

Status: March 1995

Accomplishments:

- Sought to accelerate consideration of equity in the treatment of biodiesel in the provision of excise and income tax credits now made available to bio-alcohol fuels.

- Promoted extension of the mandates in CAAA-90 and EPAct to heavy-duty diesel vehicles.

- Recommend expanded tax credits for biodiesel research, development, and demonstrations.

- Suggest the promotion of the clean fuel aspects of biodiesel through educational programs involving the public, engine and vehicle manufacturers, and state, local, and federal govemment agencies concemed with the environment, energy, and taxation.

Participants: R.F. Webb Corporation

Sponsoring Organization(s): National Biodiesel Board

Point of Contact: R.F. Webb, 1011-5 Prince of Wales Drive, Ottawa, Ont. K2C 3K1, phone 613.224.8460, fax 613.224.8077.

Paper(s):

Webb, R.F. (1995). Potential Needs for and Rational for Biodiesel Tax Incentives in the U.S.. NBB \# 404-1. Jefferson City, MO: National Biodiesel Board. Work performed by R.F. Webb Corporation. 


\section{Project Title:}

Technoeconomic Analysis of Enzymatic Esterification of Highly Fatty Acid Feedstocks.

Background: A three-way Cooperative Research and Development Agreement was put in place between NREL, ARS, and FPRF to conduct a preliminary feasibility study of the potential of enzymatic processing of low-cost sources of lipids, such as recycled cooking oils and animal fats, with various alcohols as a first step in determining the commercial potential of this new technology for use in biodiesel and biolubricant production.

\section{Objectives:}

- NREL, ARS, and FPRF will jointly conduct experimental and technoeconomic studies of the potential of biocatalysis for the production of biodiesel or biolubricants. The research will compare the effectiveness of various enzymes as catalysts for biodiesel production relative to traditional inorganic catalysts currently in use.

- Experimental work will involve batch experiments conducted at ARS's research facility in Philadelphia using commercially available enzymes.

- Technoeconomic analysis will be conducted by NREL using experimental data from ARS, as well as technical input on the process provided by both ARS and FPRP. Computer models will be developed to estimate the cost of biodiesel produced via the enzymatic route. The models will also be used in sensitivity studies to determine what types of improvements in enzyme performance are needed to make this process technology commercially available.

Status: Ongoing, completion anticipated in 1998.

Accomplishments: Researchers at USDA's Eastem Regional Research Center have conducted experiments to evaluate the performance characteristics of biodiesel made from various feedstock sources and combinations using enzymatic conversion process. The project has also examined the use of additives to improve critical fuel parameters such as cloud point and pour point. FPRF, a nonprofit, private research organization has supplied expertise on and samples from waste restaurant grease collection operations. NREL has taken the lead in developing a computer spreadsheet model of enzymatic biodiesel production to establish a baseline understanding of the costs involved.

Participants: U.S. Department of Agriculture-Agricultural Research Service, Eastern Regional Research Center, Fats and Proteins Research Foundation, and National Renewable Energy Laboratory

Sponsoring Organization(s): U.S. Department of Energy Office of Fuels Development, U.S. Department of Agriculture-Agricultural Research Service, and Fats and Proteins Research Foundation

Point of Contact: Dr. K. Shaine Tyson, National Renewable Energy Laboratory, 1617 Cole Blvd., Golden, CO 80401-3393, phone 303.275.4616, fax 303.275.4675, e-mail tysonk@tcplink.nrel.gov.

Paper(s): None available at this time 


\section{Project Title:}

The Economic Feasibility of Community Based Biodiesel Plants

Background: This project studied the costs of inputs and outputs of a biodiesel plant. It provided information on the claims of oil and meal values from extruder processes and how they related to the feasibility of small plants of this nature.

Objective: To examine the feasibility of community sized biodiesel plants and indicate which feedstocks are superior economically. In addition, other factors such as ownership arrangements, policy implications, and cost sensitivities were investigated.

\section{Status: August 1993}

Accomplishments:

- It was determined that under specific conditions, biodiesel can be processed economically at the community level.

- The results of various simulations demonstrate that without farm program benefits to minor oilseeds, soybeans are the most economic feedstock to use in a community based operation.

- If producers participate in government programs and are capable of growing minor oilseeds, canola may represent a better feedstock than soybeans. This is dependent on localized factors.

- Community based biodiesel plants will be successful for producers that are diversified in both crop and livestock operations and can utilize oilseed meals. The economics of community based biodiesel plants will be affected greatly by feedstock costs.

- The overall feasibility of a community based plant is highly dependent on a combination of factors and therefore each community's conditions would need to be considered before investing in a biodiesel plant.

Participants: MARC-IV Consulting, Inc.

Sponsoring Organization(s): University of Missouri-Columbia

Point of Contact: Alan Weber, MARC-IV Consulting Inc., 402 Oak Street, Ashland, MO 65010, phone 573.657.5537, fax 573.657.1058, e-mail aweber@marciv.com.

Paper: Weber, J.A. "The Economic Feasibility of Community Based Biodiesel Plants," A Thesis Presented to the Faculty of the Graduate School University of Missouri-Columbia. 


\section{Project Title:}

The Economics of Engine Replacement/Repair for Biodiesel Fuels

\section{Background:}

Objectives:

- Develop a dynamic control model for determining the present value of operating costs of biodiesel buses and its competitors, diesel, methanol, and CNG.

- Compare the expected life cycle costs of operating a transit bus fleet fueled with these alternative fuels.

Status: March 1995

\section{Accomplishments:}

- Biodiesel is competitive with CNG/diesel and methanol fuels, but less competitive compared with petroleum diesel fuel.

- In this present situation of liquid fuel supply and at current crude oil prices, there is no incentive to find replacements for liquid fossil fuels.

Participants: University of Georgia

Sponsoring Organization(s): University of Georgia, U.S. Department of Agriculture Office of Energy and New Uses, National Biodiesel Board, and United Soybean Board

Point of Contact: Michael Wetzstein, University of Georgia, Department of Agricultural and Applied Economics, Athens, GA 30602, phone 706.542.0758, fax 706.542.0739, e-mail mwetzstein @agecon.ga.edu.

Paper(s): None

Ahouissoussi, N.B.; Wetzstein, M.E. (1995). The Economics of Engine Replacement/Repair for Biodiesel Fuels. University of Georgia. Available from the National Biodiesel Board, Jefferson City, MO 65110. 


\section{B. Environmental Analysis}




\section{Project Title:}

Biodiesel Parks \& Environmentally Sensitive Areas Market Pre-Evaluation Study

Background: There is little information available relating specifically to the subject of the environmental consequences of operating equipment powered by compression-ignition engines in environmentally sensitive areas such as national and state parks or wetlands.

\section{Objectives:}

- Evaluate if biodiesel would be a good solution to some of the current problems plaguing sensitive land areas.

- Define the size of this market and assess the commercial viability of biodiesel in the context of federal and state regulations.

Status: Completed

Accomplishments:

- The market identified is relatively small and is likely to remain flat or decline somewhat as regulatory agencies across the board downsize in the face of substantial budget reductions.

- Biodiesel must have a competitive cost structure to the end user, whether through agency fuel requirements, lower feedstock, and conversion costs.

- Biodiesel needs to be classified as a reasonable altemative fuel classification for biodiesel under the EPAct.

Participants: National Biodiesel Board

Sponsoring Organization(s): National Biodiesel Board, United Soybean Board

Point of Contact: Ms. Bev Thessen, National Biodiesel Board, P.O. Box 104898, Jefferson City, MO, 65110-4898, phone 573.635.3893, fax 573.635.7913, e-mail

biodiesel@sockets.net.. James E. Peeples, 5894 South Sixth Street, Falls Church, VA 22041, phone 703.578.3655, fax 703.578.3230.

Paper(s):

Peeples, J.E. (1996). Biodiesel Parks \& Environmentally Sensitive Areas Market PreEvaluation Study. NBB 54113-4. Jefferson City, MO: National Biodiesel Board. Work performed by James E. Peeples, Falls Church, VA. 


\section{Project Title:}

Environmental Benefits of Biodiesel

Background: At the University of Idaho, several kinds of engine testing have been conducted. Basic engine tests, injector coking and durability tests have been performed. The conclusion is that biodiesel is essentially similar to diesel in terms of effect on the engine. Biodiesel is valuable because it is renewable and safe. In some environments, diesel fuel spills are very damaging. Thus, biodegradability and toxicity can be very important.

\section{Objectives:}

- Compare the biodegradability of biodiesel to traditional diesel.

- Compare the engine emissions of vehicles fueled with biodiesel to those fueled with traditional diesel.

Status: Completed.

\section{Accomplishments:}

- Biodiesel is safer because the flashpoint is more than $100^{\circ} \mathrm{F}$ higher than that of diesel.

- Biodegradability of REE was higher than biodegradability of reference dextrose and much higher than diesel fuel.

- Toxicity of biodiesel was at least 15 times less than diesel.

Participants: University of Idaho Department of Agricultural Engineering

Sponsoring Organization(s): University of Idaho

Point of Contact: Charles L. Peterson, University of Idaho, Moscow, ID 83844-2040, phone 208.885.7906, fax 208.885.8923, e-mail peterson @ novell.uidaho.edu.

Paper(s):

Peterson, C.L.; Reece, D. Toxicology, Biodegradability and Environmental Benefits of Biodiesel. Moscow, ID: Department of Agricultural Engineering, University of Idaho. 


\section{Outreach \& Education}

\section{A. Materials}

Also see the following projects:

Information Development, Maintenance and Distribution 
Project Title:

Transportation and Handling of Biodiesel and Biodiesel Blends

Background: To ensure adequate storage, handling, and blending of biodiesel, this project will generate guidelines to the efficient handling and transport of biodiesel and biodiesel blends. The guidelines will be targeted to suppliers, distributors, and users.

\section{Objectives:}

- Review biodiesel-related research that has produced real-world experience in the transportation and handling of biodiesel or biodiesel blends.

- Review literature related to transportation and handling of biodiesel and biodiesel blends.

- Produce a guide to the efficient handling and transportation of biodiesel and biodiesel blends.

Status: September 1, 1996-August 31, 1997

\section{Accomplishments:}

- The information hs been generated and made available to suppliers.

- This information will be used as background for developing a professional handling brochure.

Participants: University of Missouri-Columbia, Department of Biological and Agricultural Engineering

Sponsoring Organization(s): National Biodiesel Board

Point of Contact: Ms. Bev Thessen, National Biodiesel Board, P.O. Box 104898, Jefferson City, MO, 65110-4898, phone 573.635.3893, fax 573.635.7913, e-mail biodiesel@ sockets.net.

Paper: None at this time. 


\section{Project Title:}

Regulated Fleets - Core Communication

Background: This project overlapped with the Regulated Fleets EPAct Option program. The EPAct Option program was designed to educate the fleet managers about biodiesel and how it could be used to meet EPAct requirements. This project was designed to get the message to these potential consumers. The EPAct Options ' 96 Conference, held in Baltimore, was an outcome of this project and there are proceedings.

\section{Objectives:}

- Under this project, sources of information used and respected by fleets affected by EPAct will be identified.

- List of trade magazines, joumals, and other sources, which will serve as the media list for news releases and feature articles, will be developed.

- News releases, feature articles, or other communications means on biodiesel research, regulatory, and/or marketing developments will be develop and distributed.

- Additional educational material to be developed or used for increasing biodiesel awareness among fleets affected by EPAct.

Status: August, 1995-September 30, 1996.

\section{Accomplishments:}

- The FY 1996 Regulated Fleets-Core project served a vital need by increasing the lines of communication between NBB and fleets affected by EPAct. Before the EPAct Options '96 conference in Baltimore, Maryland, fleet managers were contacted to promote the beneficial aspects of the conference.

- In addition, press releases and other news media were used to ensure success of this conference. As follow-up to the EPAct Options Conference, this project was used to contact and interact with fleet managers that had expressed an interest in helping the biodiesel industry contact engine manufacturers to express the need for a biodiesel FFV.

Participants: National Biodiesel Board

Sponsoring Organization(s): National Biodiesel Board

Point of Contact: Ms. Bev Thessen, National Biodiesel Board, P.O. Box 104898, Jefferson City, MO 65110-4898, 573.635.3893, fax 573.635.7913, e-mail biodiesel@ sockets.net.

\section{Paper: None}

Additional Information: Contact NBB for the proceedings generated at the EPAct Options Conference. 


\section{B. Information Services}




\section{Project Title:}

Biodiesel Awareness and Attitudes by Transit System Managers

Background: In May 1993, Fleishman-Hillard Research reported to the National SoyDiesel Development Board on the attitudes and awareness of transit company managers with respect to biodiesel fuel. Benchmark research in 1993 demonstrated relatively low levels of awareness and mid-level familiarity with biodiesel. This report summarizes current awareness of biodiesel among a similar population of the people at transit companies responsible for fuel decisions after 15 months.

Objectives: To survey 100 transit managers to determine the level of biodiesel awareness and its use as an altemative fuel option.

Status: October 1994

\section{Accomplishments:}

- During the 15 months of this project, awareness of biodiesel as an altemative fuel increased. Now biodiesel is mentioned unaided as an altemative fuel by $35 \%$ compared to only $10 \%$ in the previous year.

- On an aided basis, $92 \%$ of transit managers now recognize biodiesel as an altemative fuel. Last year, only half $(52 \%)$ were aware of it.

- Slightly less (40\%) that half of the transit managers are more receptive to using biodiesel than they were a year ago.

Participants: Fleishman-Hillard, Inc.

Sponsoring Organization(s): National Biodiesel Board

Point of Contact: Ms. Bev Thessen, National Biodiesel Board, P.O. Box 104898, Jefferson

City, MO, 65110-4898, phone 573.635.3893, fax 573.635.7913, e-mail biodiesel @ sockets.net.

\section{Paper:}

Fleishman-Hillard, Inc. (1994). Biodiesel Awareness and Attitudes by Transit System Managers. Project \# 452-1. Jefferson City, MO: National SoyDiesel Development Board. Work performed by Fleishman-Hillard, Inc., St. Louis, MO.

Fleishman-Hillard, Inc. (1994). Survey of Mass-Transit Systems Taking Part in Biodiesel Demonstrations 1993-1994. 


\section{Project Title:}

\section{Biodiesel Core Communications-- "Biodiesel Report"}

Background: The Biodiesel Report newsletter provides coverage of regulatory news about demonstrations, research, policy development, and other pertinent information of interest to the biodiesel community. More than 3,000 subscribers rely on the Biodiesel Report for the latest biodiesel news.

\section{Objective:}

- Form a clear national biodiesel message through interaction with media and targeted stakeholders.

- Facilitate biodiesel message.

- Prepare, print and distribute Biodiesel Report.

- Facilitate membership communication.

- Prepare and distribute press releases.

Status: Continuous

Accomplishments:

- In 1997, the Biodiesel Report was redesigned to include the following categories: Market Watch, Fuels, Business, Govemment Activities, Calendar of Events, New Patents and Publications, Technology, and Miscellaneous. Five to six issues are published annually.

- In addition, in 1997, an editorial panel was formed, comprised of govemment and industry leaders.

Participants: National Biodiesel Board, Spectrum Communications, Inc., United Soybean Board

Sponsoring Organization(s): National Biodiesel Board, United Soybean Board

Point of Contact: Ms. Bev Thessen, National Biodiesel Board, PO Box 104898, Jefferson City, MO 65110-4898, 573.635.3893, fax 573.635.7913, e-mail biodiesel@ sockets.net.

Paper: Not applicable.

Additional Information:

For public information on biodiesel, call 800.841 .5849 or e-mail www.biodiesel.org NBB. 


\section{Project Title:}

Biodiesel Research at University of Georgia

Background: At the University of Georgia, engine performance and properties of biodiesel fuels have been researched since the early 1980s. Initial work was focused on blends of peanut oil with petroleum-derived diesel No. 2. Throughout the years, studies have focused on everything from diesel fuel, triglycerides, and oil extraction to viscosity.

Objective: To summarize biodiesel research conducted at the University of Georgia during the past few decades.

Status: Completed

Accomplishments:

- Measured the basic physical properties of crude peanut oil blended with ester gasoline, butanol or No. 2 diesel fuel.

- Operated campus transit buses on peanut oilNo. 2 diesel blends.

- Determined the factors affecting oil extraction and the correct conditions for optimum oil extraction.

- Conducted a series of studies to determine if a mixture of selected triglycerides might be satisfactory biodiesel fuel.

Participants: University of Georgia, Georgia Agricultural Experiment Stations

Sponsoring Organization(s): Georgia Agricultural Experiment Stations

Point of Contact: John Goodrum, University of Georgia, Biological \& Agricultural Engineering Department, Driftmier Center, Athens, GA 30602, phone 706.542.0867, fax 706.542.8806, email jooodrum@gamma.bae.uga.edu.

\section{Paper(s):}

Goodrum, J. W. (1996) "Review of Biodiesel Research at University of Georgia" Proceedings of the Third Liquid Fuels Conference, September 15-17, Nashville, TN. Liquid Fuels and Industrial Products from Renewable Resources, pp. 128-135. 


\section{Project Title:}

\section{Biofuels Presentations}

Background: A comprehensive effort is needed in outreach and education to get the message out about ethanol and biodiesel's ameliorative impacts not only on air emissions, but also their ease of implementation and performance characteristics relative to other fuels.

Objectives:

- To increase the amount of ethanol and biodiesel used in transit and fleet vehicles in the Northeast.

- A result of this project will be a list of identified key organizations that deal with transportation of fleet management issues, such as the New York State Transit Association or the National Association of Fleet Administrators.

- A team of experts (consisting of representatives from OEMs and the biofuels industry) will present reliable information and case studies to the key stakeholder/decision makers at the meeting conducted by the state officials about biodiesel by providing a "Biodiesel Briefing Book" to each state representative.

- In conjunction with this activity, NRBP will work with the DOE Clean Cities Program to distribute information on the environmental benefits of biodiesel. The project will also identify barriers to the use of biodiesel and take action to overcome the institutional and/or policy barriers to biodiesel use such as quantifying the air emission benefits of biodiesel so that states can claim emission reduction benefits under their State Implementation Plans. Lastly, it will educate state policy officials on the job creation and waste disposal benefits of biodiesel made from waste grease.

\section{Status: FY 1996-FY 1997}

Accomplishments: Activities related to this project began in the summer of 1996 and are still ongoing.

Participants: U.S. Environmental Protection Agency and Northeast Regional Biomasss Program

Sponsoring Organization(s): Northeast Regional Biomass Program

Point of Contact: Richard Handley, Northeast Regional Biomass Program, CONEG Policy Research Center, Inc., 400 N. Capitol St., Suite 382, Washington, DC 20001, phone 518.899.9572, fax 518.899.9574, e-mail thandley@ capital.net.

Papers: None available at this time. 


\section{Project Title:}

Customer Parts Assistance

Background: Consumer service and product acceptance is a vital part of market development. NBB has received numerous technical questions from potential and current consumers regarding engine equipment compatibility. This project is to establish a "phone tree" or intemet system that biodiesel customers may use to determine what parts, if any, they should change when using biodiesel, especially with older model engines.

\section{Objectives:}

- Respond to "frequently asked questions" from researchers, clients, and other individuals or companies researching biodiesel.

- The following specific objectives were approved to accomplish this broad objective

1. Develop and maintain a responsive customer parts assistance site on the Intemet that will allow end users to seek answers to frequently asked questions about the use and commercialization of biodiesel

2. Respond to customer parts assistance questions raised by individuals interested in biodiesel and its commercialization via fax, phone, and the Intemet

3. Interact with relevant agencies to stimulate interest and develop support for biodiesel research via the Internet.

Status: This project is in the process of being completed.

Accomplishments: In progress.

Participants: University of Missouri-Columbia, National Biodiesel Board

Sponsoring Organization(s): National Biodiesel Board

Point of Contact: Leon Schumacher, University of Missouri-Columbia, 235 Agricultural Engineering Bldg., Columbia, MO 65211, phone 573.882.2126, fax 573.882.3958, e-mail leon schumacher@muccmail.missouri.edu.

Paper:

The final product will be available to the public on the Biodiesel web site. 


\section{Project Title:}

Establishment of a Biodiesel Consortium in Philadelphia

Background: The main purpose of project is to promote the establishment of a biodiesel industry working group in the Philadelphia area.

Objectives:

- Establish a consortium of stakeholders from the Philadelphia area including (but not limited to) local universities, local city and state govemment entities, diesel refiners and distributors, local animal renders and restaurant grease collectors, NBB, and biodiesel producers.

- Coordinate activities of the consortium through a monthly newsletter.

Status: Ongoing--activities will be transferred to the Greater Philadelphia Clean Cities Program

Accomplishments: Four newsletters have been produced and two meetings have been held to date, and several demonstrations are being considered.

Participants: National Renewable Energy Laboratory, Seasoned Energy Development, Ltd.

Sponsoring Organization(s): U.S. Department of Energy Office of Fuels Development

Point of Contact: Dr. K. Shaine Tyson, National Renewable Energy Laboratory, 1617 Cole Blvd., Golden, CO 80401, phone 303.275.4616, fax 303.275.4675, e-mail tysonk@tcplink.nrel.gov.

Papers: Four newsletters. 


\section{Project Title:}

First Workshop: Commercialization of Biodiesel

Background: The focus of this conference was on engine manufacturers' warranty requirements for biodiesel in their engines.

Objective: To convey information regarding manufacturers warranties to key stakeholders in the industry.

Status: Completed in 1994

Accomplishments: This conference was held in 1994.

Participants: Yellowstone National Park, University of Idaho's National Center for Advanced Transportation Technologies, Pacific Northwest and Alaska Regional Biomass Energy

Program, and Westem Regional Biomass Energy Program

Sponsoring Organization(s): Pacific Northwest and Alaska Regional Biomass Energy Program and Western Regional Biomass Energy Program

Point of Contact: Craig Chase, Technology and Engineering Management, 1380 Southfork Road, Cody, WY 82414, phone 307.527.6918, fax 307.527.7049.

\section{Papers:}

Commercialization of Biodiesel: Establishment of Engine Warranties. 1995. 
Project Title:

Govemment Fleets Biodiesel Option (FY 1996)

Background: As detailed in the marketing plan (as part of the ongoing project), numerous states have formed altemative or renewable fuel task force programs. Because states are better able to introduce programs and may want to demonstrate leadership by working with tomorrow's technologies, biodiesel could find market access through state government initiatives.

\section{Objectives:}

- Work individually with "covered fleets" to position biodiesel as the least cost compliance strategy per mile driven. "Covered fleets" includes federal, state, and altemative fuel provider fleets with specific emphasis on state fleets.

- By using both performance and economic arguments to capitalize on the success of work performed in 1995, this project would both educate state agencies and provide them with the rationale to consider implementing alternative fuel strategies employing biodiesel.

Status: October 15, 1996

Accomplishments:

- Key decision makers were identified in states where activities are to be initiated, including QSSBs, DOT administrators, and maintenance supervisors, air quality officials, civic leaders, and federal fleet operators.

- Biodiesel was positioned as the least cost compliance strategy per mile driven option with individual "covered fleets."

Participants: Fleishman-Hillard, Inc.

Sponsoring Organization(s): National Biodiesel Board and United Soybean Board

Point of Contact: Ms. Bev Thessen, National Biodiesel Board, P.O. Box 104898, Jefferson

City, MO, 65110-4898, phone 573.635.3893, fax 573.635.7913, e-mail biodiesel@ sockets.net.

Paper:

Fleishman-Hillard, Inc. (1996). Government Fleets Biodiesel Option (FY 1996). NBB 96553-1. Jefferson City, MO: National Biodiesel Board. Work performed by Fleishman-Hillard, Inc., St. Louis, MO. 
Project Title:

Industrial Uses of Agricultural Materials--Situation and Outlook Report (S\&O)

Background: A number of articles on biodiesel have been published periodically in the Industrial Uses of Agricultural Materials--Situation and Outlook Report. Biodiesel information is sometimes also provided in the publication's "Fats and Oils" section (see August 1996, September 1995, June 1994, December 1993, June 1993 issues).

Objective: To release reports supplying economic information to people involved in all aspects of taking agricultural materials from the farmgate through the industrial marketplace. Data published come from government agencies, private publications, trade associations, producer and processor groups, and industry sources. Each issue of S\&O provides the national and international economic outlook followed by information on categories of industrial products. Every issue also has one or two special articles, which provide more detailed information about a specific topic.

Status: June 1993-July 1997

Accomplishments:

Biodiesel topics have been highlighted in special articles in three past issues of this S\&O.

Articles covered are:

- Microeconomics of producing biodiesel in community-based plants.

- Vehicle economics of biodiesel compared to other altemative fuels.

- Energetic and economic feasibility of converting beef tallow to biodiesel.

- Estimation of possible biodiesel demand in niche fuel markets such as federal fleets, mining, and marine/estuary areas.

Participants: Varies by article author

Sponsoring Organization(s): Commercial Agriculture Division U.S. Department of Agriculture-Economic Research Service, U.S. Department of Agriculture Research and Commercialization Corporation (provided some funding from 1993 through 1996); U.S. Department of Energy Office of Industrial Technologies (provided some funding from 19931995)

Point of Contact: Lewrene Glaser, Commercial Agriculture Division, Economic Research Service, U.S. Department of Agriculture, 1301 New York Ave, N.W. Room 832, Washington, DC 20005-4788, phone 202.219.0091, fax 202.219.0035.

Papers:

Raneses, Anton R., Lewrene K. Glaser, and Michael J. Price (1996). "Potential Niche Fuel Markets for Biodiesel and their Effects on Agriculture." Industrial Uses of Agricultural Materials--Situation and Outlook Report.

Nelson, Richard G. and Mark D. Schrock (1994). "Energetics and Economics of Producing Biodiesel from Beef Tallow Look Positive." Industrial Uses of Agricultural Materials--Situation and Outlook Report. 
Ahouissoussi, N.B.C. and M.E. Wetzstein (1995). "Life Cycle Costs of Altemative Fuels: Is Biodiesel Cost Competitive for Uban Buses?" Industrial Uses of Agricultural Materials-Situation and Outlook Report.

Weber, J.A. (1993). "The Feasibility of Producing Biodiesel in the United States Using a Community-Based Facility." Industrial Uses of Agricultural Materials--Situation and Outlook Report.

\section{Additional Information:}

Papers are available through an autofax service by dialing (on a phone connected to a fax machine): 202.219.1107 and requesting Document 13,000, which will provide a listing of the Industrial Uses of Agricultural Materials--Situation and Outlook Reports. Entire articles can also be accessed.

Access to 1995 and 1996 issues are also available on the Internet at http://usda.mannlib.comell. edu/usda. 


\section{Project Title:}

Information Development, Maintenance, and Distribution

Background: The timely availability of information and technical data is critical to any industry. This is magnified when the industry is focused on the introduction of a new product or concept. This function is provided by NBB staff. It includes responding to oral, written, and electronic requests for information, as well as managing the biodiesel library.

Objective: To develop and implement an industry education and information campaign targeted at potential users of biodiesel, key influences and the general public to build support, and understanding of the merits of biodiesel by providing a forum and presence both in print and electronically.

\section{Status: Ongoing}

Accomplishments: The NBB staff:

- Responds to approximately 800 information requests by phone, mail, Intemet, and personal contact annually.

- Responds to more than 26 small-quantity fuel sample requests.

- Participates in approximately 24 personal interviews or news releases for print or electric media.

- Collects and analyzes data to help determine the most effective way to approach the development of the biodiesel market.

- Maintains the information database that has already been created by NBB.

- Manages two new websites (www.nbb.org and www.biodiesel.org). See the related project titled World Wide Developments

Participants: National Biodiesel Board

Sponsoring Organization(s): National Biodiesel Board

Point of Contact: Ms. Bev Thessen, National Biodiesel Board, P.O. Box 104898, Jefferson City, MO 65110-4898, 573.635.3893, fax 573.635.7913, e-mail biodiesel@ sockets.net.

\section{Papers:}

Biodiesel Information Kit

Biodiesel Report

NBB sponsor research papers

Press releases

Additional Information: - Also see projects titled "World Wide Web Development" and "Biodiesel Core Commuications-- "Biodiesel Report" 


\section{Project Title:}

Research Needs Resulting from Experiences of Fueling of Diesel Engines with Biodiesel

Background: Since the 1970s, biodiesel fueled engines have been monitored by researchers under real-world operating conditions and under controlled conditions in the laboratory. The time that each vehicle has been monitored has ranged from 1 week to 14 years. Nearly all research since the mid-1980s has focused on blends of biodiesel and low sulfur petroleum diesel fuel that have ranged from $10 \%$ to $50 \%$ biodiesel. Engine operating expenses such as fuel consumption and maintenance costs have been recorded for several of the engines.

Objectives:

- Identify issues conceming material compatibility and fuel quality.

- Review the real-world data collected between 1991 and 1995 concerning the fueling of diesel-powered vehicles with $100 \%$ biodiesel and blends of biodiesel with diesel fuel

Status: 1996

\section{Accomplishments:}

- Fuel quality issues and loss of power were consistently reported in tests.

- Fuel filter plugging and material compatibility problems were common difficulties.

- Explored the issues that must be addressed in order to commercialize biodiesel.

Participants: University of Missouri

Sponsoring Organization(s): University of Missouri and lowa State University

Point of Contact: Leon Schumacher, University of Missouri-Columbia, 235 Agricultural Engineering Bldg., Columbia, MO 65211, phone 573.882.2126, fax 573.882.3958, e-mail leon schumacher@muccmail.missouri.edu.

\section{Paper(s):}

Schumacher, L. G.; Van Gerpen, J. (1996). "Research Needs Resulting from Experiences of Fueling Engines with Biodiesel." Proceedings of the Third Liquid Fuel Conference, September 15-17, Nashville, TN, pp. 207-216. 


\section{Project Title:}

Second Workshop: Commercialization of Biodiesel, Environmental and Health Benefits

Background: The focus of this conference was on the environmental and health benefits of using biodiesel.

Objective: To convey information regarding the environmental and health benefits of biodiesel.

Status: Held in May 1996

Accomplishments: This conference was held in 1996.

Participants: Montana Department of Environmental Quality, Yellowstone National Park, and the University of Idaho's National Center for Advanced Transportation Technologies

Sponsoring Organization(s): Pacific Northwest and Alaska Regional Biomass Energy Program, and Westem Regional Biomass Energy Program

Point of Contact: Craig Chase, Technology and Engineering Management, 1380 Southfork Road, Cody, WY 82414, phone 307.527.6918, fax 307.527.7049.

Papers:

Commercialization of Biodiesel: Environmental and Health Benefits. June 1997. 
Project Title:

Third Workshop: Commercialization of Biodiesel: Producing a Quality Fuel

Background: This is the third annual conference intended to bring interest and constituency groups together to share knowledge and information about biodiesel performance.

\section{Objectives:}

- To produce a statement on needs related to fuel quality and production.

- This conference will be a kickoff event for the 200,000 mile over-the-road truck demonstration project; to review production methods, analysis procedures, and standards related to producing a quality biodiesel fuel; and to report on recent studies related to emissions, environment and health.

Status: July 9-10, 1997

Accomplishments: N/A

Participants: Idaho Department of Water Resources Energy Division, University of Idaho National Center for Advanced Transportation Technologies, Caterpillar Inc., J.R. Simplot Co., PN\&A, NRPB

Sponsoring Organization(s): Pacific Northwest and Alaska Regional Biomass Energy Program, Northeast Regional Biomass Program, and U.S. Department of Energy Office of Transportation Technologies

Point of Contact: Craig Chase, Technology and Engineering Management, 1380 Southfork Road, Cody, WY 82414, phone 307.527.6918, fax 307.527.7049.

Papers: None available at this time. 


\section{Project Title:}

Troubleshooting Field Problems with Biodiesel

Background: The purpose of this project is to provide a quick response to technical questions that arise from the use of biodiesel and biodiesel blends in real-world situations. As with any newly marketed product, biodiesel in-use problems are going to occur, particularly with biodiesel blends. To avoid false information, the products success is dependent upon identifying field problems and addressing them as soon as possible.

\section{Objectives:}

- Develop a "NBB Troubleshooting Team" consisting of biodiesel researchers, industry and research technicians and develop a "NBB Troubleshooting Team Response Plan" to be used as a model when responding to problems related to biodiesel and biodiesel blend fueling.

- Develop and use a "troubleshooting log" that documents the efforts of the NBB Troubleshooting Team.

- Secure the services of consultants to visit the site of the problem and gather additional information about the problem.

- Secure mail sample containers to biodiesel users as appropriate.

- Analyze the samples using basic techniques and photograph each sample, consult with MARC-IV to determine the laboratory best suited to analyze samples that are taken.

- Submit samples for analysis to the NBB approved laboratory, review the findings provided by the laboratory and submit recommendations conceming the problem.

Status: August 1995-March 31, 1997 (continuous)

Accomplishments:

- Provided NBB with crucial program support by providing an opportunity to identify specific reasons for concern during project implementation or demonstrations.

- Seventeen separate sites were analyzed as well as four sites visits to identify errors use, sampling, mixing, storage, and application: Michigan Pickup Tanks I \& II, U.S. Bureau of Mines, Waco, Fishel Construction, National Biological Survey, M.U.I, Columbus Oil, M.U II, USDA, AEP, NOPEC, TRT, ETS, U.S. Postal Trip, Wolfang Klein, and Craig McCaw Boat.

Participants: System Lab Services and Schumacher Consulting

Sponsoring Organization(s): National Biodiesel Board and United Soybean Board

Point of Contact: Ms. Bev Thessen, National Biodiesel Board, P.O. Box 104898, Jefferson

City, MO, 65110-4898, phone 573.635.3893, fax 573.635.7913, e-mail biodiesel@ sockets.net.

Paper: None available at this time. 


\section{Project Title:}

\section{World Wide Web Development}

Background: In this age of electronic communications, NBB determined that a web site would aide in information dissemination and improve customer service.

Objective: Develop and maintain the NBB web and e-mail service.

Status: October 1, 1996-August 31, 1997

Accomplishments:

- Domain names registered.

1. nbb.org

2. biodiesel.org

- Analysis phase complete.

- Design phase under way.

Participants: ArachNet, Inc., NBB

Sponsoring Organization(s): NBB

Point of Contact: Ms. Bev Thessen, National Biodiesel Board, P.O. Box 104898, Jefferson City, MO, 65110-4898, phone 573.635.3893, fax 573.635.7913, e-mail biodiesel@ sockets.net.

Paper: None available at this time. 


\section{Index of Project Titles}

1

1997 FutureCar Challenge

2

2-Cycle Engine 200 Hour EMA Test with Hydrogenated Soy Ethyl Ester (HySEE) .109

A

A Proposed Biodiesel Development Plan

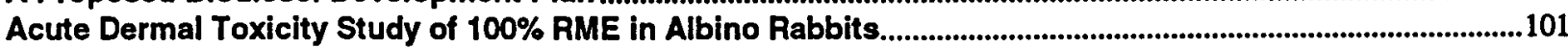

Additive Compatibility

Agricultural and Rural Transportation Systems.

Alternative Fuels and Lubricants from Rapeseed.......................................................................................................110

An Analysis of Economic and Environmental Impacts of Using Biodiesel in the Kansas City Metropolitan

Area

Assessment of Biomass Feedstocks Suitable for the Production of Liquid Biofuels .........................................16

Assessment of the Potential for Biodiesel Rapeseed Production in the Southeast .............................................253

ASTM Standards Development and Industry Acceptance

B

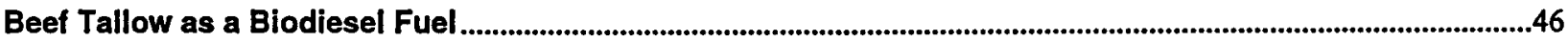

Bioblended Fuel for Use in Light-Duty Compression Ignition Engines ................................................................120

Biodegradability and Toxicity of Biodiesel Fuels...........................................................................................................102

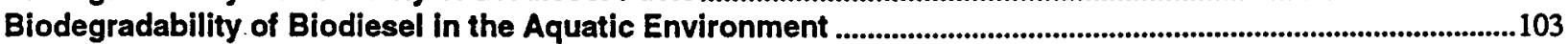

Biodegradation of Synthetic Diesel................................................................................................................................104

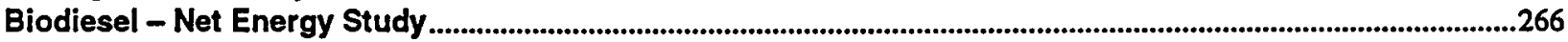

Biodiesel Awareness and Attitudes by Transit System Managers ..........................................................................282

Biodiesel Blends in a DDC Series 60 Engine at High Altitude ..........................................................................119

Biodiesel Blends in lowa Underground Storage Tanks............................................................................................95

Biodiesel by Indirect Liquefaction...................................................................................................................................31

Biodiesel Cetane Number Engine Testing Comparison to Calculate Cetane Index Number................................47

Biodiesel Core Communications -..............................................................................................................................................292

Biodiesel Core Communications - "Biodiesel Report" ...........................................................................................283

Biodiesel From Canola

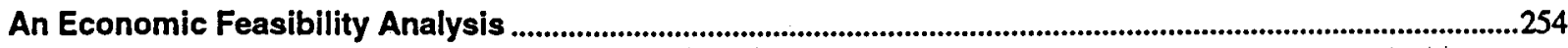

Biodiesel from Microalgae

Complementarity in a Fuel Development Strategy..........................................................................................17

Biodiesel Fuel Certification and Quality Assurance ..................................................................................................48

Biodiesel Fuel Evaluation for the U.S. Army Tactical Wheeled Vehicles....................................................................190

Biodiesel Fuels Demonstration During the 1996 Olympics..........................................................................................191

Biodiesel Fuels-Vegetable Oil/Alcohol Blends ..........................................................................................................49

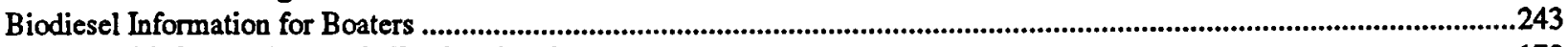

Biodiesel Injector Deposit Evaluation Test .............................................................................................................170

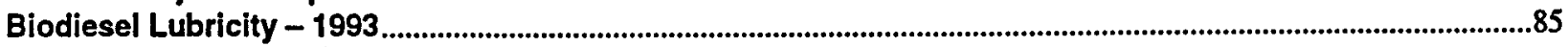

Biodiesel Lubricity Quantifications - Low Blends ..................................................................................................8.

Biodiesel Market Opportunities and Potential Barriers ...............................................................................................222

Biodiesel Parks \& Environmentally Sensitive Areas Market Pre-Evaluation Study..............................................276

Biodiesel Pour Point and Cold Flow Study............................................................................................................52

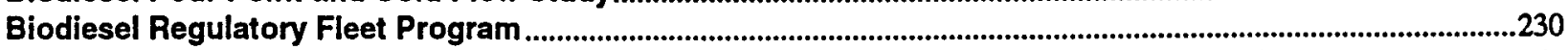

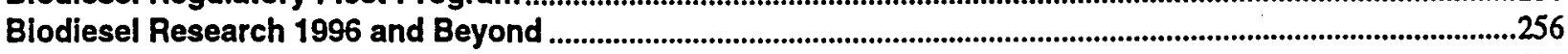

Biodiesel Research at University of Georgia ........................................................................................................28

Biodiesel Research Progress

1992-1997. 
Biodiesel Research, Development and Demonstration Support .........................................................................192

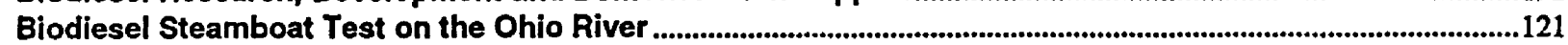

Biodiesel Technical Fuel Quality Laboratory Analysis........................................................................................53

Biodiesel Use in Underground Metal and Non-Metal Mines.............................................................................................122

Biodiesel: A Partial Substitute for Diesel in Transit Buses..............................................................................................169

Biodiesel: Potential Economic Benefits to lowa and lowa Soybean Producers................................................25

Biofuel Co-Product Development..........................................................................................................................................13

Biofuels Infrastructure Development.....................................................................................................................................240

Biofuels Presentations .................................................................................................................................................................285

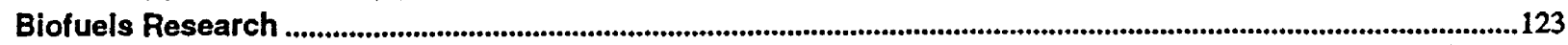

Biomass-Derived Alternatives in High Performance Snowmobile Engines: A Snowmobile in the Park .......193

Bi-State Development Agency Alternative Fuel Bus Testing of 10 Buses............................................................194

Blending Rules for Formulating Biodiesel Fuel.....................................................................................................................54

Boston Bus Fleet Operating on Biodiesel in Boston, Massachusetts .................................................................196

Boston, Massachusetts Garage Retrofit with Biodiesel Tanks ...........................................................................................96

C

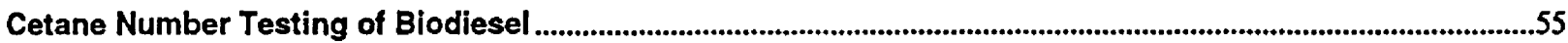

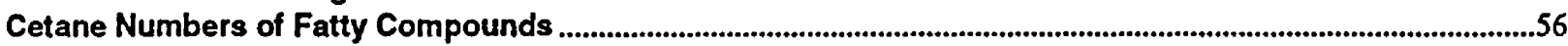

Chemical and Biological Characterization of Emissions from a Biodiesel-Fueled Underground Mining Diesel

Engine with and Without and Oxidation Catalytic Converter ..........................................................................124

Chesapeake Bay Marine Market Biodiesel Use Program ...............................................................................................241

Clean Air Partners_Biodiesel Water Shuttles at Logan Airport ............................................................................197

Close-Out of Microalgae Component of Biodiesel Program..................................................................................18

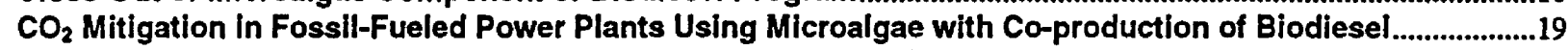

Combustion Analysis of Esters of Soybean Oil in a Diesel Engine .....................................................................231

Commercialization Prospects for Biodiesel...................................................................................................179

Compare Life Cycle Costs of Alternative Fuels (Biodiesel, Compressed Natural Gas, and Methanol in Urban

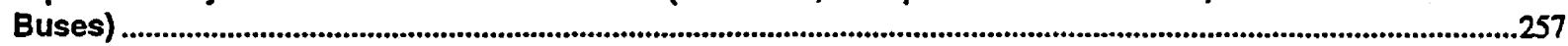

Comprehensive Emissions and Chemical Characterization of Rapeseed Oil-Derived Biodiesel ........................126

Congressional Research on Biodiesel Fuel ..................................................................................................................180

Conversion of Glycerol from SoyDiesel Production to 1,3 Propanediol...................................................................258

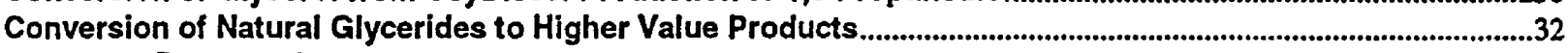

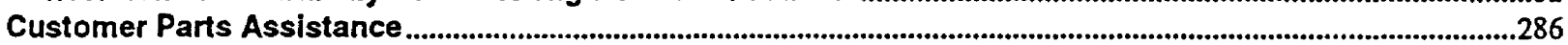

D

DDC 6V-71N Emission Testing on Diesel \& Biodiesel Blend

127,158

DDC 6V-92TA MUI Coach Upgrade Emission Optimization on 20\% Soydiesel Blend.......................................128

Demonstrate 35 Percent Biodiesel Blends in Line Haul Tractors Using DDC Series 60 and Cummins 855

Engines .................................................................................................................................................................................198

Demonstrate and Promote Biodiesel as a Transportation Fuel .........................................................................199

Demonstrate Biodiesel in Commuter Trains and Buses...............................................................................................200

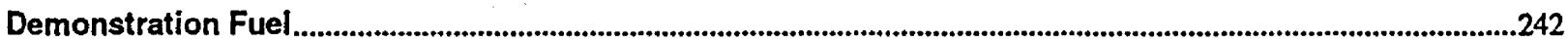

Demonstration of the On-the-Road Use of Biodiesel ..........................................................................................201

Developing Yellow Mustard (Sinapis Alba L.) Cultivators Suitable for Biodiesel Production in the United

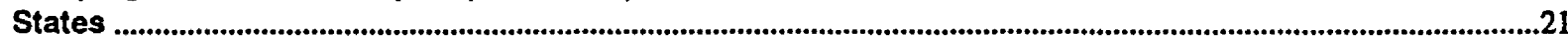

Development of Biodiesel for Use in High-Speed Diesel Engines .....................................................................129

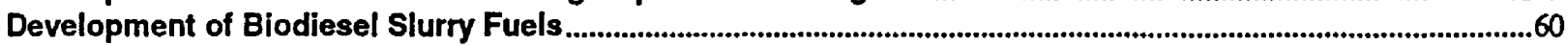

Development of Premium Diesel Fuel Standards ......................................................................................57

Development of Rapeseed Biodiesel for Use in High-Speed Diesel Engines ..................................................202

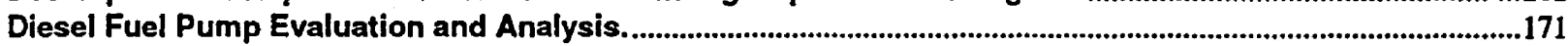

Diesel Fuel, Extenders and Additives from Vegetable Oils........................................................................................58

$\mathbf{E}$

Economic Impacts of Biodiesel use in a Midwestern State Vehicle Fleet.

Effects of an Oxidation Catalytic Converter and a Biodiesel Fuel on the Chemical, Biological, and Particle

Size Characteristics of Emissions from an IDI Diesel Engine.. 
Effects of Methyl Esters of Tallow and Grease on Exhaust Emissions and Performance of a Cummins L10 Engine

Emission Characteristics of Methyl Soyate in Underground Mining Engines.......................................................133

Emission Performance of Biodlesel Fuels in Heavy-Duty Pickup Truck ................................................................134

Emission Performance of Selected Biodiesel Fuels as a Platform for Future Diesel Alternative Evaluations

Emissions and Engine Performance from Blends of Soya and Canola Methyl Esters with ARB \#2 Diesel in a DCC 6V92TA MUI Engine.

Emissions and Performance Characteristics of a 4-Stroke, Direct Injected Diesel Engine Fueled with Blends of Biodiesel and Low Sulfur Diesel Fuel...

Emissions Characteristics of Ethyl and Methyl Ester of Rapeseed Oil Compared with Low Sulfur Diesel Control Fuel in a Chassis Dynamometer Test of a Pickup Truck. 137

Emissions Characteristics of Soy Methyl Ester Fuels in an IDI Compression Ignition Engine.

Emissions Characteristics of Soy Methyl Ester Fuels in an Underground Mining Diesel Engine with and without Diesel Oxidation Catalyst Aftertreatment.

Emissions from Biodiesel Blends and Neat Biodiesel from a 1991 Model Series 60 Engine Operating at High Altitude.

Emissions Tests with an On-Road Vehicle Fueled with Methyl and Ethyl Esters of Rapeseed Oil...................143

Engine Exhaust Emissions Evaluation of a Cummins L10E when Fueled with a Biodiesel Blend ..................145

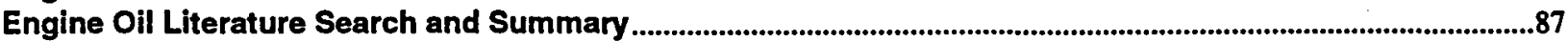

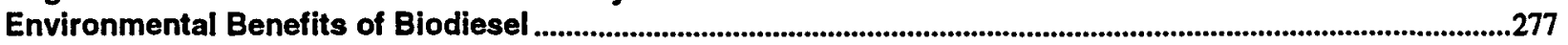

Establishment of a Biodiesel Consortium in Philadelphia ......................................................................................28

Estimating Price and Nonprice Impact of Producing Biomass on CRP Acreage .................................................260

Ethyl Ester Process Scale-Up and Biodegradability of Biodiesel ..............................................................................35

Evaluation of Biodiesel in an Urban Transit Bus Powered by a 1981 DDC8V71 Engine ....................................147

Evaluation of Methyl Soyate/Diesel Blend in DDC 6V-92TA Engine: Optimization of NOx Emissions ............148

Expanded Rapeseed Ethyl Ester (REE) Demonstration and Testing, and Cooperative Development of Hydrogenated Soy Ethyl Ester (HySEE) Biodiesel.

\section{F}

Field Trials of Soy Methyl Ester as a Fuel for Diesel Powered Equipment in Underground Mines.

First Workshop Commercialization of Biodiesel

Fuel Road Tax Investigation.

.262

Fueling Direct Injected Diesel Engines with 100\% Neat Biodiesel................................................................................151

Fueling Urban Buses with Soydiesel-Diesel Fuel Blending .......................................................................................204

Fuels and Fuel Additives Registration Regulations............................................................................................181

G

Government Fleets Biodiesel Option (FY 1996)

H

Hydrogenated Soy Ethyl Ester (HySEE) Process Refinement........................................................................................37

Hydrogenated Soy Ethyl Ester (HySEE) Production and Engine Durability Test Project ....................................206

Hydrogenated Soy Ethyl Ester (HySEE), Preliminary Processing and Screening Work .........................................14

\section{I}

Identification of Chemical Changes Occurring During the Transient Injection of Selected Vegetable Oils..112 Identification of Elements Found in Increased Soluble Fraction of Particulate Emissions with a Methyl

Soyate Blend

Ignition and Combustion Characteristics of Biofuels

Improving the Low-Temperature Properties of Alternative Diesel Fuels

Vegetable Oil-Derived Methyl Esters.

Industrial Agricultural Products Center

Industrial Products from Agricultural Resources.

Industrial Uses of Agricultural Materials-Situation and Outlook Report (S\&O) .................................................290

Information Development, Maintenance and Distribution. 
lowa Ames Transit Agency Biodiesel Bus Demonstration .219

lowa Heavy Vehicle Fleet Biodiesel Test at lowa Department of Transportation, Boone Maintenance Facility

lowa Metropolitan Transit Agency (MET) Biodiesel Demonstrations.

L

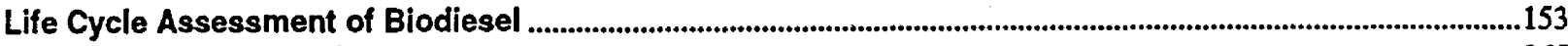

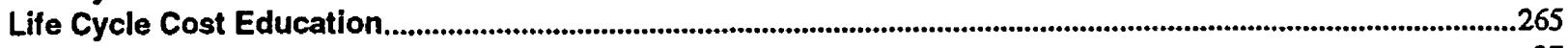

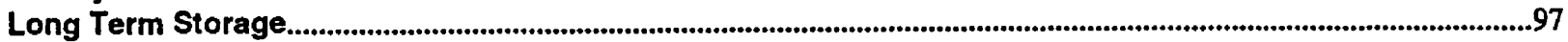

Low Blend Level Test Market (Premium Diesel Market) ..................................................................................232

Low-Temperature Filterability Properties of Alternative Diesel Fuels from Vegetable Oils .................................63

Low-Temperature Properties of Triglyceride-Based Diesel Fuels

Transesterified Methyl Esters and Petroleum Middle Distillate/Ester Blends ...................................................65

\section{$\mathbf{M}$}

Manufacturing Incentives for Alternative Fuel Vehicles, 1996

Marine Blodiesel and Education Project for San Francisco Bay and Northern California ....................................243

Marine Biodiesel Use and Education...............................................................................................................................244

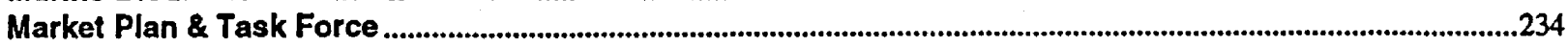

Massachusetts Biodiesel Shuttle System.............................................................................................................208

Massachusetts Possible Biodiesel Use to Meet Emission Standards for Clean Air Act Compliance .............155

Materials Compatibility, Fuel Blend Characteristics, Engine Dynamometer Evaluation.......................................81

Mechanisms of Emissions Reduction Using Biodiesel Fuels .............................................................................156

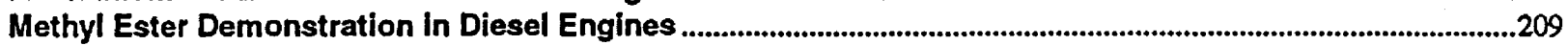

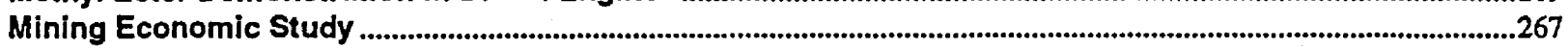

Monitor Biodiesel Use in Selected Tactical Vehicles at Yuma, Arizona ...............................................................115

Multifeedstock Biodiesel Project Project (in earlier phase, the project was titled..................................................23

$\mathrm{N}$

National Alternative Fuels Laboratory-Phase V . .66

National Soydiesel Development Board Standards for Biodiesel ...........................................................................68

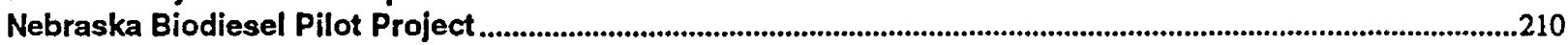

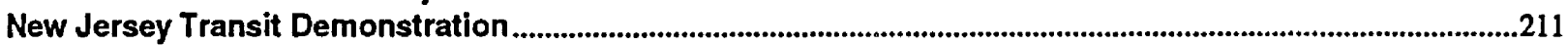

New Processes for Obtaining Higher Value-Added Products from Agricultural Lipids ........................................38

Nonfood Agricultural Products Project ...........................................................................................................................69

Non-Fuel Industrial Uses of Soybean Oil-based Esters ......................................................................................................235

Northeast Study on Large Diesel Engines ...................................................................................................................................157

$\mathbf{0}$

Oilseeds

Commercializing Biodiesel and Other Products...............................................................................................268

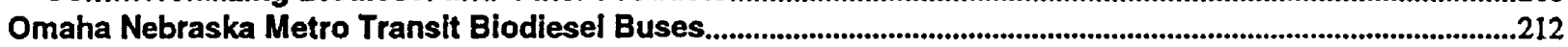

Over-the-Road Heavy-Duty Diesel Engine Operational Demonstration .................................................................213

Overview of 1000 Hour Durability Testing DDC 6V-92TA DDCII Engine........................................................................172

Oxidative and Thermal Stability Testing Method(s) for Biodiesel ................................................................................71

\section{$\mathbf{P}$}

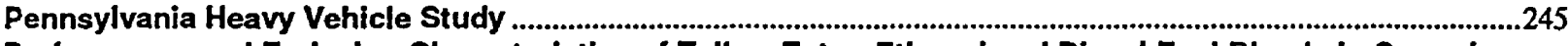

Performance and Emission Characteristics of Tallow Ester, Ethanol and Diesel Fuel Blends in Cummins

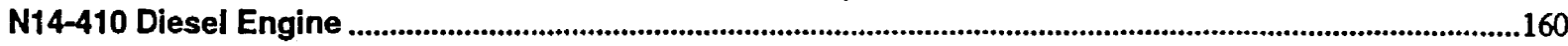

Performance and Emissions of Vegetable Oil Hybrid Fuels ...............................................................................174

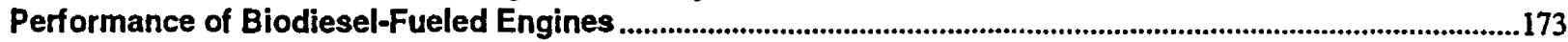

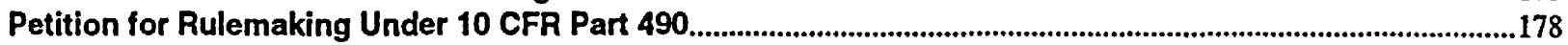

Physical Characterization of Biodiesel/Low Sulfur Diesel Fuel Blends ..................................................................77

Pilot Demonstration of Biodiesel in Tourism-Related Transportation

A Truck in the Park. 
Potential Feedstock Supply and Costs for Biodiesel Production .............................................................................25

Potential Niche Markets for Biodiesel and their Effects on Agriculture .....................................................................236

Power, Emissions, and Bioresponse of Biodiesel in a Marine Environment.........................................................116

Prevailing Markets for Biodiesel Feedstocks-An Empirical Overview, Washington, D.C..................................27

Process Scale-Up for Catalytic Oxidation of Unsaturated Fatty Acids and Glycerolysis..................................39

Process Scale-up for Transesterification an Glycerolysis of Soybean Oil Utilizing a High Shear Liquid-

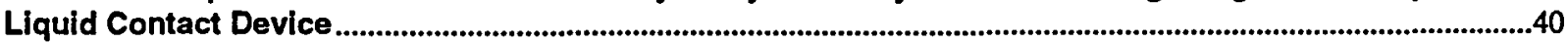

Production and Testing of Ethyl and Methyl Esters ..................................................................................................175

Program Management and Planning for Advanced Materials from Renewable Resources .................................88

Promotion of Agricultural Soydiesel Use in South Carolina .....................................................................................215

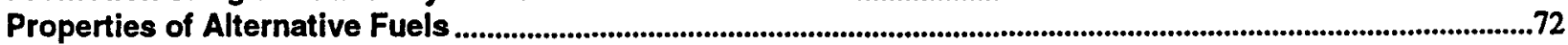

$\mathbf{R}$

Rapeseed and Safflower Oils as Diesel Fuels.......................................................................................................73

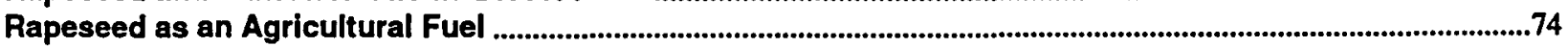

Rapeseed Oil as a Fuel for Agriculture .......................................................................................................................28

Regulated Fleets - Core Communication .................................................................................................................................280

Regulated Fleets Marketing Assistance and Physically Market the Fuel .........................................................246

Research Needs Resulting from Experiences of Fueling of Diesel Engines with Biodiesel.................................293

Rhode Island Energy Office and Department of Transportation Ferry Boat Program .......................................216

Rhode Island Energy Office Education Program with Pleasure Craft .......................................................................247

$\mathbf{S}$

Sample Analysis from Biodiesel Test, University of Missouri-Columbia...................................................................176

Second Workshop

Commercialization of Biodiesel, Environmental and Health Benefits.................................................................294

Soy Diesel Processing Buchanan County, Missouri

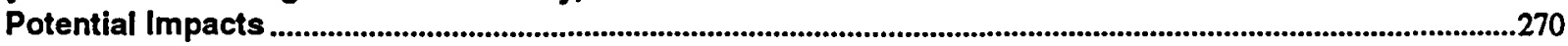

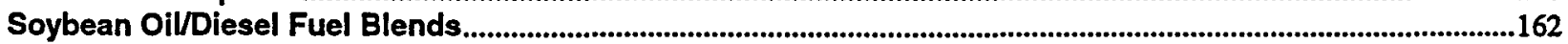

Soy-Diesel Blends' Use In Aviation Turbine Engines.....................................................................................................217

State of Massachusetts Commuter Boat Operation in Boston Harbor .................................................................248

Summary of State Alternative Fuel Programs .........................................................................................................185

$\mathbf{T}$

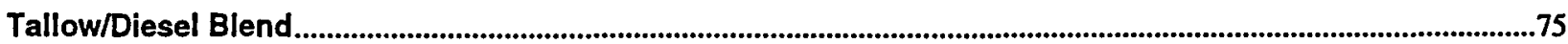

Tallow-Based Biodiesel Test at the Kansas City Area Transit Authority .......................................................218

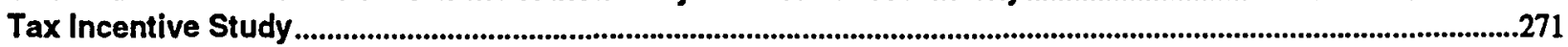

Technoeconomic Analysis of Enzymatic Esterification of Highly Fatty Acid Feedstocks. ................................272

Technology for Efficient Use of Agricultural-Resources ................................................................................................163

The Economic Feasibility of Community Based Biodiesel Plants ...............................................................................273

The Economics of Engine Replacement/Repair for Biodiesel Fuels ....................................................................274

The Effect of Biodiesel Fuel Composition on Diesel Combustion and Emissions..............................................164

The Influence of Various Oxygenated Compounds on the Cetane Numbers of Fatty Acids and Esters...........76

The Relationship Between Fuel Lubricity and Diesel Injection System Wear .........................................................90

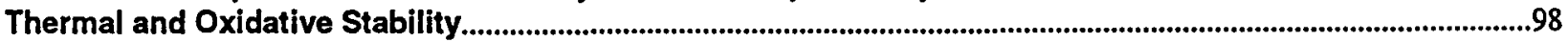

Third Workshop

Commercialization of Biodiesel: Producing a Quality Fuel............................................................................295

Toxicity of Particulate and Semi-Volatile Emissions from SME and Biodiesel Blended Fuels..........................106

Transesterification Process to Manufacture Ethyl Ester of Rape Oil.....................................................................78

Transient Emission Evaluation of Biodiesel Fuel Blend in a 1987 Cummins L10 and DDC 6V-92-TA............166

Transient Emissions from No. 2 Diesel and Biodiesel Blends in a DDC Series 60 Engine...............................167

Transient Emissions Testing of Biodiesel and Other Additives in a DDC Series 60 Engine ..............................165

Transportation and Handling of Biodiesel and Biodiesel Blends ..........................................................................279

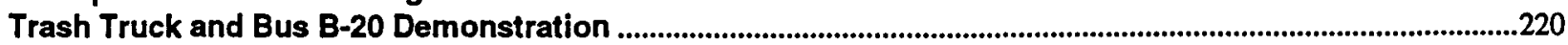

Troubleshooting Field Problems with Biodiesel ......................................................................................................296

Twin Cities, Minnesota Biodiesel Pickup Truck Demonstration .............................................................................221

Two Year Storage Study with Methyl and Ethyl Esters of Rapeseed..........................................................................99 
$\mathbf{U}$

University of Minnesota Neat Biodiesel Pickup Demonstration and Outreach Project

University of Southern Indiana Biodiesel Use

Use of Biodegradable, Seed-Based, Automotive Engine and Transmission Lubricants, Industrial Lubricants, and Chemical Additives.

Use of Seed-Based Lubricants as a Replacement for Petroleum Oil ...............................................................93

Use of Vegetable Oil as Fuel for Compression Ignition, Internal Combustion Engines......................................92

\section{V}

Vegetable Oils as Alternative Diesel Fuels.

Virginia Biodiesel Bus Demonstration and Test Operation .............................................................................................224

Virginia Boat Operating on Biodiesel

\section{W}

Waco and Washington, lowa Community School District School Bus Demonstrations Using Biodiesel......226 Washington State Biodiesel Use in the Puget Sound...........................................................................................249

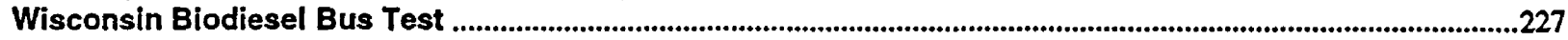

World Wide Web Development............................................................................................................................297

World Wide Web Developments..................................................See Information Development, Maintenance and Distribution

\section{Index of Paper Titles}

\section{1}

100,000 Miles of Fueling 5.9 L Cummins Engines with 100 Percent Biodiesel......153, 185

1000 Hour Engine Durability Testing with HySEE.....196

13C-NMR Spectroscopy Of Unsaturated Long-Chain Compounds

An Evaluation ... Carbon Signals As Rational Functions.....50

1996 Manufacturing Incentives for Alternative Fuel Vehicles.....173

1996-1998 Biodiesel Marketing Plan.....224

\section{6}

6V-92TA DDC Engine Exhaust Emission Tests Using Metbyl Ester Soybean Oil/Diesel Fuel Blends.....152

\section{A}

A Continuous Process for the Conversion of Vegetable Oils into Biodiesel......40

A Proposed Biodiesel Development Plan......241

Acute Dermal Toxicity Study of $100 \%$ RME in Albino Rabbits.....97

Aerobic and Anaerobic Biodegradation of the Methyl Esterified Fatty Acids of Soy Diesel in Freshwater and Soil

Environments.....101

Aggregation Of Unsaturated Long-Chain Fatty Alcohols In Nonaqueous Systems.....49

Allylic mono- and dibydroxylation of isolated double bonds with selenium dioxide-tert-butyl......50

Alternative Approaches to the Production of Biofuels......33

Alternative Fuel Transit Bus Evaluation Program Results.....185

Alternative Fuel Transit Buses: Final Results from the National Renewable Energy Laboratory Vehicle Evaluation

Program.....184

An Alternative Fuel for Urban Buses - Biodiesel Blends.....195

An Analysis of Economic and Environmental Impacts of Using Biodiesel in The Kansas City Metropolitan Area....242

Analysis Of Lipoxygenase Kinetics By High Performance Liquid Chromatograpby With A Polymer Column......33

Analysis Of Lipoxygenase Multiple Substrate Kinetics By Reverse-Phase HPLC With A Polymer-Based Column......33

Aquatic Biomass Resources and Carbon Dioxide Trapping.....20

Assignment of 13C Nuclear Magnetic Resonance Signals in Fatty Compounds with Allylic Hydroxy Groups.....49

B

Beef Tallow as a Biodiesel Fuel.....45 
Bioblended Fuel for Use in Light-Duty Compression Ignition Engines.....116

Biodegradability of Biodiesel in the Aquatic and Soil Environments......36

Biodegradability of Biodiesel in the Aquatic Environment.....99

Biodiesel Awareness and Attitudes by Transit System Managers.....272

Biodiesel by Indirect Liquefaction.....31

Biodiesel Cetane Number Engine Testing Comparison to Calculated Cetane Index Number.....46

Biodiesel Cost Comparison for Urban Buses.....247

Biodiesel from Canola: An Economic Feasibility Analysis.....244

Biodiesel From Microalgae

Complementarity in a Fuel Development Strategy......17

Biodiesel Fuel......88

Biodiesel Fuel Evaluation for the U.S. Army Tactical Wheeled Vehicles.....180

Biodiesel Fuel Quality Standards and Recommended Operating Protocols for Maintaining Fuel Quality.....47

Biodiesel Fuel Technology for Military Application - Interim Report.....79

Biodiesel Fuel: What Is It? Can It Compete.....170

Biodiesel Fuels Demonstration During the 1996 Olympics in Athens, Georgia.....181

Biodiesel Fuels Quality Evaluation Using Commercial Materials/Chemical Testing Laboratories.....52

Biodiesel Information for Boaters.....233

Biodiesel Information Kit.....282

Biodiesel Market Opportunities and Potential Barriers.....219

Biodiesel Options EPACT Proceeding.....220

Biodiesel Parks \& Environmentally Sensitive Areas Market Pre-Evaluation Study.....266

Biodiesel Pour Point and Cold Flow Study.....51

Biodiesel Production Potential from Industrial Rapeseed in the Southeastern U.S......243

Biodiesel Production Potential in Missouri in Missouri Farm Financial Outlook 94.....253

Biodiesel Research - 1996 and Beyond.....185, 246

Biodiesel Research Progress 1992-1997.....227

Biodiesel Use in Underground Metal and Non-Metal Mines.....118

Biodiesel: Potential Economic Benefits to Iowa and Iowa Soybean Producers.....245

Biodiesel: The Use of Vegetable Oils and Their Derivative as Alternative Diesel Fuels.....49

Blending Rules for Formulating Biodiesel Fluid.....53

C

Cetane Number Testing of Biodiesel.....54

Cetane Numbers of Fatty Compounds Influence of Compound Structure and Various Potential Cetane Improvers.....55

Chemical and Biological Characterization of Emissions from a Biodiesel-Fueled Underground Mining Diesel Engine With and

Without an Oxidation Catalytic Converter.....120

Chesapeake Bay Marine Market Biodiesel Use Program.....231

$\mathrm{CO}_{2}$ Capture and Biofuels Production with Microalgae.....19

Collection and Collation of Performance Data From Urban Mass Transit Biodiesel Demonstrations.....195

Combustion Analysis of Esters of Soybean Oil in a Diesel Engine.....221

Commercialization of Biodiesel: Environmental and Health Benefits. June 1997......284

Commercialization of Biodiesel: Establishment of Engine Warranties. 1995......278

Commercialization Prospects for Biodiesel......169

Compatibility of Elastomers and Metals in Biodiesel.....79

Continuous Transesterification of Vegetable Oils and Utilization of Co-Product.....41

Conversion of Glycerol from SoyDiesel Production to 1,3-Propanediol.....248

Cost Benefit Analysis of Rapeseed Production.....192

Cost Implications of Feedstock Combinations for Biodiesel Production.....254

Cost Implications of Innovative Feedstock Combinations for Biodiesel Production.....254

$\mathbf{D}$

DDC 6V-92TA MUI Coach Upgrade Emission Optimization on 20\%/80\% Soy/Diesel Blend.....123

DDC6V-71N Emission Testing on Diesel and Biodiesel Blend......122, 150

Demonstration of the On-the-Road Use of Biodiesel.....191

Design and Development of Hyades, a Parallel Hybrid Electric Vehicle for the 1997 FutureCar Challenge.....178

Determination of Additive Compatibility and Efficacy......43

Developing Canola Quality Cultivators From Yellow Mustard.....22 
Development of a Continuous Process for Making Biodiesel from Waste French Fry Oil and Ethanol, Hydrogenated Soy Ethyl Ester (HySEE) Process Refinement.....37

Development of Biodiesel for Use in High-Speed Diesel Engines.....124

Development of Biodiesel Slurry Fuels.....59

Development of Rapeseed Biodiesel for Use in High-speed Diesel Engines.....193

Draft ASTM Standard.....44

\section{$\mathbf{E}$}

Economic Comparison of Biodiesel Blends to Commercially Available Exhaust Emission Reduction Technologies for Underground Mines.....257

Economic Impacts of Biodiesel use in a Midwestern State Vehicle Fleet.....249, 259

Effect of Talc on Properties of Corn Starch Extrudates.....110

Effects of an Oxidation Catalytic Converter and a Biodiesel Fuel on the Chemical, Biological, and Particle Size Characteristics of Emissions from and DI Diesel Engine......125

Effects of Biodiesel Blended Fuels and Multiple Injections on D.L Diesel Engine Emissions.....147

Effects of Methyl Esters of Tallow and Grease on Exhaust Emissions and Performance of a Cummins L10 Engine......126

Effects of Structure of Fatty Compounds on their Cetane Numbers.....58

EMA 200 Hour Test, Rapeseed Methyl Ester and Ethyl Esters and Diesel Fuel.....192

Emissions and Engine Performance from Blends of Soya and Canola Methyl Esters with ARB \#2 Diesel in a DCC 6V92TA MUI Engine.....130

Emissions and Lubricity Evaluation of Rapeseed Derived Biodiesel Fuels.....121

Emissions and Performance Characteristics of a 4-Stroke, Direct Injected Diesel Engine Fueled with Blends of Biodiesel and Low Sulfur Diesel Fuel......131

Emissions Characteristics of Ethyl and Methyl Ester of Rapeseed Oil Compared with Low Sulfur Diesel Control Fuel in a Chassis Dynamometer Test of a Pickup Truck.....107, 132

Emissions Characteristics of Ethyl and Methyl Ester of Rapeseed Oil Compared with Low Sulfur Diesel Control Fuel in a Chassis Dynamometer Test of a Pickup Truck......29

Emissions Characteristies of Soy Methyl Ester Fuels in an IDI Compression Ignition Engine.....133

Emissions Characteristics of Soy Methyl Ester Fuels in an Underground Mining Diesel Engine with and without Diesel Oxidation Catalyst Aftertreatment.....134

Emissions from Biodiesel Blends and Neat Biodiesel from a 1991 Model Series 60 Engine Operating at High Altitude.....115

Emissions from Biodiesel Blends and Neat Biodiesel from a 1991 Model Series 60 Engine Operating at High Altitude......135

Emissions Testing with Blends of Esters of Rapeseed Oil Fuel With and Without a Catalytic Converter.....107

Emissions Testing With Blends Of Esters Of Rapeseed Oil Fuel With And Without A Catalytic Converter.....29

Emissions Tests with an On-Road Vebicle Fueled with Methyl and Ethyl Esters of Rapeseed Oil.....136

Energetics and Economics of Producing Biodiesel from Beef Tallow Look Positive.....280

Engine Exhaust Emissions Evaluation of a Cummins L10E When Fueled with a Biodiesel Blend.....137

Engine Oil Impact Literature Search and Summary.....83

Engine Performance and Emissions with Methyl and Ethyl Esters of Rapeseed Oil.....29, 107

Engineering Analysis of Microalgae Technology with Recommendations for Laboratory Research.....20

Environmental And Health Effects Of Biodiesel.....29

Enzyme Assisted Formation Of Fatty Acid Hydroperoxide.....33

Ethanol Production By Continuous Cofermentation Of Whey And Corn.....68

Ethanol Work at the EERC National Alternative Fuels Laboratory.....65

Ethyl Ester of Rapeseed Used as a Biodiesel Fuel - A Case Study.....29; 107

Evaluation and Cost of Compliance Analysis of Biodiesel Fuel for MBTA Buses......189

Evaluation of a Tallow/Diesel Blend in a DDC 6V-92TA Engine.....73

Evaluation of Biodiesel in an Urban Transit Bus Powered by a 1981 DDC8V71 Engine.....138

Evaluations of Methyl Soyate/Diesel Blend in a DDC 6V-92TA Engine: Optimization of NO Emissions.....139

Examination Of The Action Of Soybean Lipoxygenase-1 On Acylglycerols And Phospboglycerides......33

\section{$\mathbf{F}$}

Fatty Alcohols Through Hydroxylation of Symmetrical Alkenes with Selenium Dioxide/Tert-Butylhydroperoxide.....49

Field Trials of Soy Methyl Ester as a Fuel for Diesel Powered Equipment in Underground Mines.....141

Final Report on the Twin Cities, Minnesota Biodiesel Pickup Truck Demonstration.....212

Fuel Production Quality Assurance Plan.....203

Fuel Road Tax Investigation.....252

Fueling A Diesel Engine With Methyl Ester Soybean Oil.....153

Fueling Bus and Truck Engines with Soy Diesel.....210

Fueling City of Columbia Diesel Engines with a 20/80 Soydiesel Blend.....210 
Fueling Diesel Engines with Blends of Methyl Ester Soybean Oil and Diesel Fuel.....152

Fueling Direct Injected Diesel Engines with 100\% Neat Biodiesel......142

Fueling Engines with Soy Diesel/Diesel Fuel Blends.....199

Fueling Urban Buses with Soydiesel-Diesel Fuel Blending.....194

G

Gasoline Evaporative Emissions-Ethanol Effects on Vapor Control Canister Sorbent Performance.....64

Glycerolysis of Fats and Metbyl Esters.....40

Government Fleets Biodiesel Option (FY 1996).....279

\section{$\mathbf{H}$}

Heavy-Duty Exhaust Emission Tests Using Soydiesel/Diesel Fuel Blends.....153

How Much Energy Does It Take to Make a Gallon of Soydiesel.....256

How To Regulatory Compliance Guide.....56

HySEE Preliminary Processing and Screening, Making and Testing a Biodiesel Fuel Made from Ethanol and Waste French-Fry Oil.....14

\section{I}

Identification of Chemical Changes Occurring During the Transient Injection of Selected Vegetable Oils.....108

Identification of Elements Found in Increased Soluble Fraction of Particulate Emissions with a Methyl Soyate Blend.....143

Implications of Federal Policy Decisions on the Production and Use of Biodiesel.....253

Improved Conversion of Plant Oils and Animal Fats into Biodiesel and Co-product......41

Improved Method for Extraction of Hydroperoxide Lyase from Chlorella......33

Improving the Low-Temperature Properties of Alternative Diesel Fuels

Vegetable Oil-Derived Methyl Esters.....60

Improving the Low-Temperature Properties of Alternative Diesel Fuels: Vegetable Oil-Derived Methyl Esters.....49

Improving the Low-Temperature Properties of Biodiesel......57

Industry Expands Use Of Agricultural Commodities.....258

Information Development, Maintenance and Distribution.....268

Investigation of Biodiesel Fuel Technology for Military Application.......79

Iowa Department of Transportation Heavy Duty Vehicle......197

\section{$\mathbf{L}$}

Laboratory Study of the Effects of Reformulated Gasoline on Motor Vehicle Fuel Economy in Southwestern Wisconsin.....65

Life Cycle Assessment of Biodiesel Versus Petroleum Biodiesel Fuel.....144

Life Cycle Assessment of Petroleum-Based Diesel Fuel and Biodiesel.....144

Life Cycle Assessment of Petroleum-Based Diesel Fuel and Biodiesel- Final Scoping Document......145

Life Cycle Assessment of Petroleum-Based Diesel Fuel and Biodiesel-Data Summary Document......145

Life Cycle Costs of Alternative Fuels

Is Biodiesel Cost Competitive for Urban Buses?.....247, 281

Lipase-Catalyzed Production of Biodiesel......33

Low-Temperature Filterability Properties of Alternative Diesel Fuels from Vegetable Oils.....49, 62, 63

Low-Temperature Properties Of Alkyl Esters Of Tallow And Grease......33

Low-Temperature Properties of Triglyceride-Based Diesel Fuels

Transesterified Methyl Esters and Petroleum Middle Distillate/Ester Blends.....49

Lubricating Qualities of Biodiesel and Biodiesel Blends.....82

Lubricity, The Biodiesel Advantage......82

\section{M}

Macroeconomic And Fiscal Impacts Of A 57 Million Liter Corn-To-Ethanol Plant In North Missouri.....251, 259

Macroeconomic Effects Of A Community-Based Biodiesel Production System.....250, 259

Market Opportunities for Diesel Technology

State Government Fleets and Energy Policy Act Mandates.....223

Mechanical Properties Of Soy Protein-Polyetbylene Ribbon And Film.....110

Microbial Stability Of Methyl.....110

Mixing Effects on the Transesterification Kinetics of Soybean Oil.....40

Modeling of soybean oil bleaching using a surface diffusion relationship.....84 
Multi-Feedstock Biodiesel Project Phase II - Final Report.....24

\section{$\mathbf{N}$}

National Soydiesel Development Board Standards for Biodiesel.....66

Non-Fuel Industrial Uses of Soybean Oil-based Esters and Attachments.....225

$\mathbf{0}$

Overview of 1000 Hour Durability Testing DDC 6V-92TA DDC II Engine.....162

Oxidation of acylglycerols and phosphoglycerides by soybean lipoxygenase......33

Oxidative Stability Literature Review Report.....69

\section{$\mathbf{P}$}

Performance and Durability Testing of Diesel Engines Using EthylMethyl Ester Fuels.....107

Performance and Emission Characteristics of Tallow Ester, Ethanol and Diesel Fuel Blends in Cummins N14-410 Diesel Engine......151

Petition For Rulemaking Under 10 CFR Part 490.....168

Photosynthetic Conversion of $\mathrm{CO}_{2}$ to Biomass.....20

Physical Properties Of Tallow Ester And Diesel Fuel Blends.....68

Physical, Mechanical, And Thermal Properties Of Starch-Based Plastic Foam.....68

Potential Analytical Measurement Techniques for Oxidative and Thermal Stability Report.....69

Potential Feedstock Supply and Costs for Biodiesel Production.....25

Potential Needs for and Rational for Biodiesel Tax Incentives in the U.S......261

Potential Niche Fuel Markets for Biodiesel and their Effects on Agriculture.....280

Potential Niche Markets for Biodiesel and Their Effects on Agriculture.....226

Power Emissions, and Bioresponse of Biodiesel in a Marine Environment.....112

Power Plant Flue Gas as a Source of $\mathrm{CO}_{2}$ for Microalgae Cultivation

Technology and Economics of $\mathrm{CO}_{2}$ Recovery and Delivery.....20

Prevailing Markets for Biodiesel Feedstocks-An Empirical Overview.....27

Processing, Characterization and Performance of Eight Fuels from Lipids.....36, 107

Producing Biodiesel for the 'Truck in the Park' Project....204

Production and Testing of Ethyl and Methyl Esters.....165

Production of Biodiesel and Utilization of By-Product......41

Production Of Biodiesel, Lubricants And Fuel And Lubricant Additives......33

Properties of Alternative Fuels.....70

Pseudomonas Oleovorans Is A Gamma Proteobacterium.....100

Q

Quantitation Of Neutral Lipid Mixtures By High Performance Liquid Chromatography With Light Scattering Detection.....33

$\mathbf{R}$

Rapeseed and Safflower Oils as Diesel Fuels.....71

Rapeseed Oil as Diesel Fuel an Overview......72

Recent Advances in the Development of Alternative Diesel Fuel from Vegetable Oils and Animal Fats.....58

Recommendations for Stability Method(s) For Biodiesel, Letter Report.....69

Recommended Rating System and Analysis Report.....69

Recovery Of 2,3-Butanediol Byvacuum Membrane Distillation.....68

Red River Valley Clean Cities to Anchor Northern End of Midcontinent Trade Corridor.....65

Report on Fuel Dock Environmental Tax Regulations.....233

Report on Use of Marine Biodiesel in Recreational Boats.....233

Research Needs Resulting from Experiences of Fueling Engines with Biodiesel......185, 283

Review

Utilization of Rapeseed Oil, Rapeseed Oil Methyl Ester or Diesel Fuel

Exhaust Gas Emissions and Estimation of Environmental Effects.....185

Review of Biodiesel Research at University of Georgia.....274

Round-Robin Test Protocol Report.....69 


\section{$\mathbf{S}$}

Screening Test for Rape Ethyl Ester 2-Cycle Oils.....105

The Feasibility of Producing Biodiesel in the United States Using A Community-Based Facility in Industrial Uses of Agricultural Materials.....253

Snowmobiles in Yellowstone: Biomass Alternatives to Reduce Pollution.....183

Solubilization and Related Phenomena in Nonaqueous Triolein/Unsaturated Long Chain Fatty Alcohol/Methanol Solutions.....50

Solubilization of Methanol and Triglycerides Unsaturated Long-Chain Fatty Alcohol/Medium-Chain Alkanol Mixed Amphiphile Systems.....49

Source Book 1997.....87, 89

Soy Diesel Processing in Buchanan County, Missouri

Potential Impacts.....260

Soy-Diesel Blends Use in Aviation Turbine Engines.....207

Status Report on the Truck in the Park Demonstration Project.....204

Summary of State Alternative Fuel Programs, Requirements, and Opportunities for Biodiesel.....175

Summary of the New Fuel and Fuel Additive Registration Regulations.....172

Surface Tension Studies On Novel Allylic Mono-And Dihydroxy Fatty Compounds. A Method To Diastereomers.....49

Survey About Biodiesel Exhaust Emissions and Their Environmental Effects.....185

Survey of Mass-Transit Systems Taking Part in Biodiesel Demonstrations 1993-1994.....272

Systems and Economic Analysis of Microalgae Ponds for Conversion of $\mathrm{CO}_{2}$ to Biomass.....19

\section{$\mathbf{T}$}

Technical Aspects of Biodiesel Standards.....49

Technical Handbook on Marine Biodiesel.....233

The 1997 Obio State University Future Car.....178

The Annual Report for Biodiesel Researcb, Development, and Demonstration Support.....182

The Concept of Producing Biodiesel at the Community Level Instead of on an Industrial Scale.....254

The Economic Feasibility of Community Based Biodiesel Plants.....253, 263

The Economics of Engine Replacement/Repair for Biodiesel Fuels......264

The Effect of Biodiesel Fuel Composition on Diesel Combustion and Emissions.....154

The Energy \& Environmental Research Center National Alternative Fuels Laboratory.....65

The Feasibility of Producing Biodiesel in the United States Using a Community-Based Facility.....281

The Influence of Rural Road Quality on Vehicle Fuel Consumption......114

The Influence of Various Oxygenated Compounds on the Cetane Numbers of Fatty Acids and Esters.....49, 74

The Physical and Chemical Characterization of Biodiesel/Low Sulfur Diesel Fuel Blends.....75

The Relationship Between Fuel Lubricity and Diesel Injection System Wear......86

The Transportation Industry in Rural America.....114

The Use Of Microalgae For Assimilation And Utilization Of Carbon Dioxide From Fossil Fuel-Fired Power Plant Flue Gas.....20

Thermal and Oxidative Stability of Biodiesel.....94

Toxicology, Biodegradability and Environmental Benefits of Biodiesel.....267

Transesterification Process to Manufacture Ethyl Ester of Rape Oil.....76

Transient Emission Evaluation of Biodiesel Fuel Blend in a 1987 Cummins L10 and DDC 6V-92-TA.....156

Transient Emissions from No. 2 Diesel and Biodiesel Blends in a DDC Series 60 Engine.....157

Transient Emissions from No. 2 Diesel and Biodiesel Blends in a DDC Series 650 Engine.....115

Transient Emissions Testing of Biodiesel and other Additives in a DDC Series 60 Engine.....155

Two Year Storage Study with Methyl and Ethyl Esters of Rapeseed.....29, 95, 107

V

Vegetable Oils as Alternative Diesel Fuels: Degradation of Pure Triglycerides During the Precombustion Phase in a Reactor Simulating a Diesel Engine......77

\section{W}

Winterized Methyl Esters from Soybean Oil

An Alternative Diesel Fuel with Improved Low-Temperature Properties.....57 


\section{Index of Sponsors}

A

Agriculture Utilization Research Institute.....134

American Soybean Association......168, 169

B

Black Hawk County and Metropolitan Transit Authority.....179

C .

Caterpillar Inc.......103

Cetane Numbers of Fatty Compounds

Influence of Compound Structure and of Various Potential Cetane Improvers.....58

City of Boston.....186, 238

City of Lincoln, Nebraska.....202

Colorado School of Mines......135

Congressional Research Service......170

CRGO, Idabo.....21

Cytoculture Environmental Inc.....234

D

DuPont Educational Grants.....59

$\mathbf{E}$

Executive Office of Administration and Finance, Division of Energy Resources.....146

F

Farm Bureau.....228

Farmland Coop.....222

Fats \& Proteins Research Foundation, Inc......24, 56, 126, 262

Federal Transit Administration, Office of Technical Assistance and Safety.....70

Final Alternative Fuel Transit Bus Evaluation Results.....185

Fosseen Manufacturing and Development.....73, 139, 152, 179

G

General Motors Company.....213

Georgia Agricultural Experiment Stations.....274

Great Lakes Regional Biomass Energy Program.....116

I

Idaho Department of Water Resources, Energy Division.....124, 132, 136

Illinois Soybean Checkoff Board.....24, 93

Indiana Soybean Board.....222

Indiana Soybean Growers Association.....207

International Energy Agency (IEA) Alternative Motor Fuels Committec.....129

Iowa Department of Transportation......91, 197, 209

lowa Energy Center.....54, 154

Iowa Soybean Promotion Board.....54, 154, 221, 245

Iowa State University.....221, 283 


\section{K}

Kansas Corn Commission.....59

Kansas State University.....25

$\mathbf{L}$

Library of Congress......170

\section{M}

MARC-IV Consulting, Inc.....25, 118, 249

Maryland Departments of Agriculture, Environment and Natural Resources.....231

Maryland Soybean Board.....231

Massachusetts Bay Transit Authority.....92

Massachusetts Bay Transportation Authority.....146, 198

Metro Transit of Nebraska.....202

Michigan Technological University.....120

Midwest Biofuels, Inc......46

Minnesota Soybean Association.....213

Minnesota Soybean Board.....236

Mobile Sources Division of Environment Canada.....138

\section{$\mathbf{N}$}

National Biodiesel Board.....24, 43, 44, 47, 51, 52, 62, 66, 75, 81, 82, 83, 85, 93, 94, 112, 122, 123, 125, 131, 134, 137, 138, $140,142,143,147,149,155,156,160,161,162,165,166,168,169,173,175,184,194,201,219,220,222,223,224$, $225,231,232,235,236,246,248,252,256,257,261,264,266,269,270,272,273,276,279,282,286,287$

Nebraska Soybean Association.....202

Nebraska Soybean Board.....40

New England Power.....187

Northeast Regional Biomass Energy Program.....13, 16, 148, 189, 190, 206, 230, 237, 255, 275, 285

\section{O}

Ohio Soybean Council.....224

ORTECH International.....152

\section{$\mathbf{P}$}

Pacific Northwest and Alaska (PN\&A) Regional Biomass Energy Program.....14, 37, 105, 121, 124, 132, 136, 165, 182, 183, $191,192,193,196,203,204,278,284,285$

Pennsylvania Turnpike Commission.....235

Pittsburgh Energy Technology Center.....19

Posey County Co-op.....228

Public Utilities Commission.....117

\section{S}

Southeast Regional Biomass Energy Program.....181, 199, 205, 210, 243

Southwest Research Institute.....77

State Agency Transit Autbority.....92, 186

State of Indiana.....83

State of Iowa.....91

State of Minnesota Department of Public Service.....213

\section{T}

Technology Development Centre of Finland.....129

Tennessee Agricultural Experiment Station.....112

Twin Rivers Technologies, Inc......186, 187 
U

U.S. Army Belvoir Research, Development and Engineering Center, Logistics Equipment Directorate.....86

U.S. Army Tank-Automotive and Armaments Command.....180

U.S. Army Test and Evaluation Command......180

U.S. Bureau of Mines......133

U.S. Bureau of Mines Air Quality Division.....140

U.S. Bureau of Mines-Twin Cities Research Center.....120, 134

U.S. Council for Automotive Researcb......177

U.S. Department of Agriculture......31, 55, 74, 77, 108, 134

U.S. Department of Agriculture Alternative Agriculture Research and Commercialization Corporation.....280

U.S. Department of Agriculture/Economic Research Service/Office of Energy and New Uses.....241

U.S. Department of Agriculture-Agricultural Research Service.....32, 38, 60, 72, 76, 119, 124, 163, 262

U.S. Department of Agriculture-Agricultural Research Service, National Center for Agricultural Utilization Research.....49, 57, 61,164

U.S. Department of Agriculture-Alternative Agricultural Research and Commercialization Corporation (AARC).....87, 89

U.S. Department of Agriculture-Cooperative State Research, Education, and Extension Service.....28, 35, 39, 40, 53, 64, 67, $79,84,88,98,99,100,106,109,111,114,127,136,153,159,250,253,258$

U.S. Department of Agriculture-Economic Research Service.....27, 226, 247, 280

U.S. Department of Agriculture-Economic Research Service/Office of Energy and New Uses.....144

U.S. Department of Agriculture-Office of Energy and New Uses.....27, 247, 264

U.S. Department of Energy......31, 160, 177, 184, 188, 234

U.S. Department of Energy-Office of Fuels Development....13, 17, 18, 19, 24, 47, 56, 69, 103, 144, 227, 233, 262,277

U.S. Department of Energy-Office of Heavy Vehicle Technologies.....115, 128, 129, 211, 216

U.S. Department of Energy-Office of Industrial Technologies.....280

U.S. Department of Energy-Office of Transportation Technologies......157, 285

U.S. Environmental Protection Agency.....31, 171, 187

United Soybean Board.....44, 94, 160, 161, 166, 224, 236, 264, 266, 279, 286

University of Cincinnati.....117

University of Georgia.....264

University of Idaho.....71, 72, 95, 97, 244, 267

University of Kansas.....59

University of Minnesota.....114

University of Missour-Columbia.....263

University of Missouri.....25, 152, 242, 260, 283

University of Missouri Department of Agricultural Engineering.....75

University of Nebraska-Lincoln.....40, 45, 151

University of Southern, Indiana.....228

\section{V}

Virginia Marine Resources Board.....215

Volvo-Penta.....112

\section{W}

Washington State Energy Office.....239

Washington State University.....239

Western Regional Biomass Energy Program.....200, 208, 278, 284

Wisconsin Soybean Association.....217 


\title{
References
}

Cundiff, J.S., ed. (1996). "Liquid Fuel and Industrial Products from Renewable Resources." Proceedings of the Third Liquid Fuel Conference, September 15-17, 1996, Nashville, TN. St. Joseph: The American Society of Agricultural Engineers

Unpublished USDA Literature Search

Library of Congress databases

Personal interviews

Web searches

\section{Biodiesel Project Websites}

\author{
Biodiesel From Rapeseed \\ http://www.crest.org/renewables/bioenergy-list-archive/msg00253.html
}

Biodiesel Fuel Produced in Florida to be used by lowa

http://www.elecpubs.sae.org/APN/20001007.htm

Biodiesel Marine Demonstration Project

http://www.erc.uic.edu/erc/bio d/report.html

Biodiesel Page Dynamometer Test Results

http://www.uidaho.edu/bae/biodiesel/test.html

Biodiesel Project Management, Market Development

http://www.esd.oml.gov/BFDP/BFDPMOSAIC.doedocs/94 95sum/biodsl.html

Chicago Soy-Based Biodiesel Project

http://www.ag.uiuc.edu/-il-qssb/96news/chicago.html

Hybrid Electric Vehicle Program

http://www.hev.doe.gov/components/biodiesel.html\#doe

University of Idaho Tests Biodiesel

http://www.gromedia.com/atn/atn-art.html

National Biodiesel Board

http://www.biodiesel.org

University of Georgia Biodiesel Demonstration Project

http://www.bae.uga.edu/outreach/biodiesel/index.html

University of Missouri Biodiese//Biofuels Research (Leon Schumacher) http://www.missouri.edu/ pavt0689/biofuel.html 
http://www.dieselnet.com/technical.html

http://www.biodiesel.ag.uidaho.edu/projects.htm!

For more information contact Sally Evans. Phone: 303.275 .4363

e:mail: sally_evans@nrel.gov. 


\section{REPORT DOCUMENTATION PAGE}

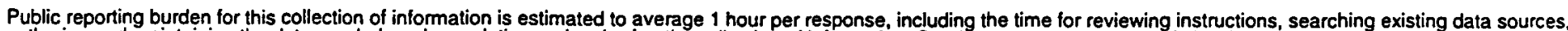

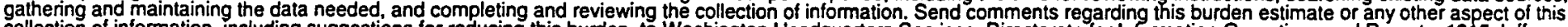

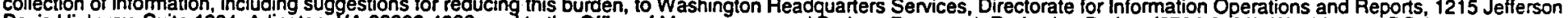
Davis Highway, Suite 1204, Arlington, VA 22202-4302, and to the Office of Management and Budget, Paperwork Reduction Project (0704-0188), Washington, DC 20503.

\begin{tabular}{|l|l|l|}
\hline 1. AGENCY USE ONLY (Leave blank) & $\begin{array}{l}\text { 2. REPORT DATE } \\
\text { April } 1998\end{array}$ & $\begin{array}{l}\text { 3. REPORT TYPE AND DATES COVERED } \\
\text { Subcontract Report }\end{array}$ \\
\hline
\end{tabular}

\section{TITLE AND SUBTITLE}

5. FUNDING NUMBERS

Biodiesel Research Progress BF886001

1992-1997

\section{AUTHOR(S)}

K. Shaine Tyson

7. PERFORMING ORGANIZATION NAME(S) AND ADDRESS(ES)

National Renewable Energy Laboratory

1617 Cole Boulevard

Golden, CO 80401-3393

Information Resources, Inc.

Contract \#: ACG-7-17046-01

Dyncorp Information \& Engineering Technology Contract \#: YAH-5-15099-01

9. SPONSORING/MONITORING AGENCY NAME(S) AND ADDRESS(ES)

National Renewable Energy Laboratory

1617 Cole Boulevard

Golden, CO 80401-3393

8. PERFORMING ORGANIZATION REPORT NUMBER

\section{SUPPLEMENTARY NOTES}

\section{2a. DISTRIBUTION/AVAILABILITY STATEMENT}

National Technical Information Service

U.S. Department of Commerce

5285 Port Royal Road

Springfield, VA 22161

13. ABSTRACT (Maximum 200 words) This document, funded by DOE, is a comprehensive summary of relevant biodiesel and biodiesel-related research, development, demonstration, and cornmercialization projects completed and/or started in the United States between 1992 and 1997. It was designed for use as a reference tool to those evaluating biodiesel's potential as a clean-burning alternative motor fuel. It encompasses, federally, academically, and privately funded projects.

\section{SUBJECT TERMS}

biodiesel, esterification, biomass

17. SECURITY CLASSIFICATION OF REPORT
18. SECURITY CLASSIFICATION OF THIS PAGE
19. SECURITY CLASSIFICATION OF ABSTRACT
15. NUMBER OF PAGES 300

16. PRICE CODE 